АХБОРОТ-КУТУБХОНА ЖУРНАЛИ
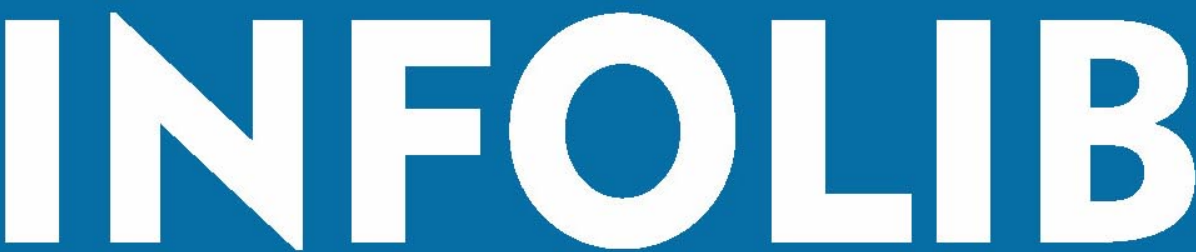

ИНФОРМАЦИОННО-БИБЛИОТЕЧНЫЙ ЖУРНАЛ
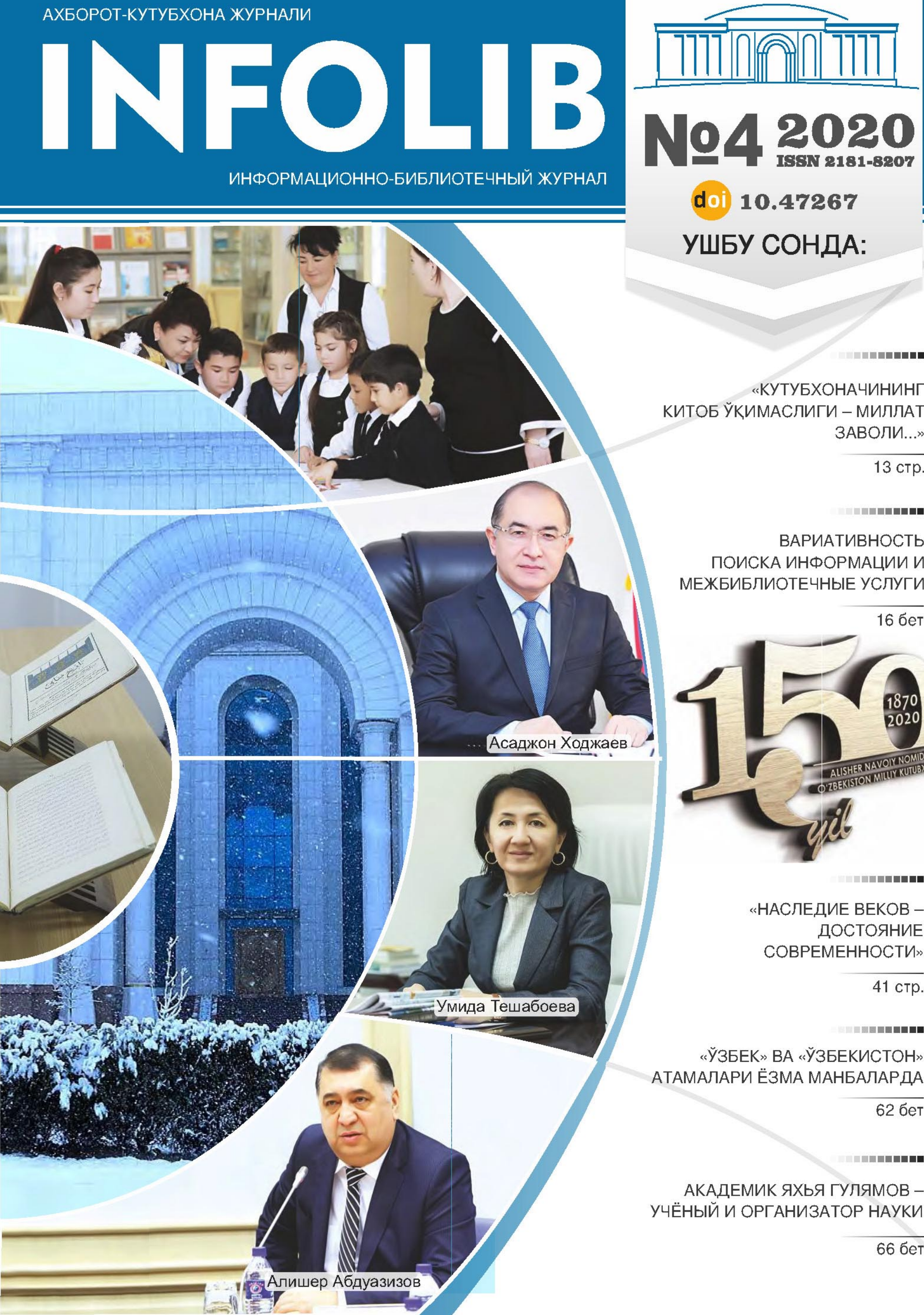

\title{
doi 10.47267
}

\section{УШБУ СОНДА:}

부붐뭄ำ

«КУТУБХОНАЧИНИНГ КИТОБ ЎҚИМАСЛИГИ - МИЛЛАТ ЗАВОЛИ...»

13 стр.

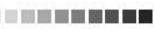

ВАРИАТИВНОСТЬ

ПОИСКА ИНФОРМАЦИИ И МЕЖБИБЛИОТЕЧНЫЕ УСЛУГИ

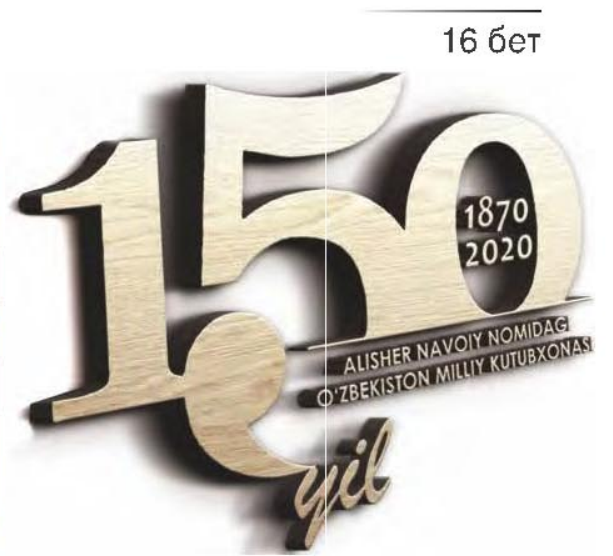

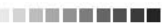

«НАСЛЕДИЕ ВЕКОВ ДОСТОЯНИЕ COBPEMEHНOСТИ»

$41 \mathrm{ctp}$.

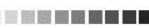

«ЎЗБЕК» ВА «ЎЗБЕКИСТОН» АТАМАЛАРИ ЁЗМА МАНБАЛАРДА

62 бет

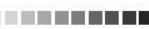

АКАДЕМИК ЯХЬЯ ГУЛЯМОВ УЧЁНЫЙ И ОРГАНИЗАТОР НАУКИ 


\section{УШБУ СОНДА: \\ B HOMEPE:}

\section{ТАХРИРИЯТДАН - ОТ РЕДАКЦИИ}

1

Кутубхоначилик сохасида қувончли воқеа

\section{МИНБАР - ТРИБУНА}

НАЦИОНАЛЬНАЯ БИБЛИОТЕКА УЗБЕКИСТАНА: ИЗ ИСТОРИИ СТаНОВЛЕНИЯ и современный этап развития. У. Тешабаева

\section{ЯНГИЛИКЛАР - НОВОСТИ}

Новости информационно-библиотечной сфреры в мире

\section{УШБУ СОН МЕХМОНИ - ГОСТЬ НОМЕРА}

«Кутубхоначининг китоб ўқимаслиги - миллат заволи...». А. Умаров

\section{ХАЛКАРО АМАЛИЁТ - МЕЖДУНАРОДНАЯ ПРАКТИКА}

Вариативность поиска информации и межбиблиотечные услуги. И. Красильникова

Транссрормация библиотеки Киевского Национального университета культуры и искусств в научно-информационный центр. Ю. Горбань Экосистема инновационной инсрраструктуры. Д. Цукерблать Организация и развитие культурно-просветительской деятельности библиотек-музеев: проблемы и достижения. В. Соколов "Наследие веков - достояние современности». Н. Зөмкова Мобильное библиотечное обслуживание на примере Новосибирской Областной детской библиотеки им. А. М. Горького. О. Костина

\section{Библиотеки. М. Эрдман}

\section{АМАЛИЁТ - ПРАКТИКА}

Ахборот-кутубхона муассасаларини ривожлантиришда фраолият самарадорлигини бахолайдиган мезонлардан фройдаланиш истиқболлари. Т. Ахмөдов

История деятельности Службы инфрормационно-коммуникационных технологий Национальной библиотеки Узбекистана. С. Холбоев Значение, инсрормационных процессов в психологическом развитии и жизни человека. Л. Мухамөдова

\section{МЕРОС - НАСЛЕДИЕ}

«Уัзбек» ва «Ўзбекистон» атамалари ёзма манбаларда. Ш. Камолиддин Академик Яхья Гулямов - учёный и организатор науки. Ф. Шамукарамова Ўзбекистон Миллий кутубхонаси тарихидан: кутубхонанинг 1930 - 1940-йиллардаги фаолияти. Ф. Нуриддинова Ўзбекистон Республикасининг Биринчи Президенти электрон архивининг яратилиши. А. Ишматов

Садри Зиё томонидан тузилган «Мажмуаи тазкор» кўлёзмаси. О. Масалиөва Мусульманские святыни в Санкт-Петербурге - территория смыслов. Ш. Ганиева

\section{ДУНЁ КУТУБХОНАЛАРИ}

170 йиллик тарихга эга Перт шахри кутубхонаси. Г. Хомидова
«INFOLIB»-

ахборот-кутубхона журнали

Информационно-библиотечный хурнал

$$
- \text { «INFOLIB» }
$$

\section{№ 4 (24) 2020 й.}

Алишер Навоий номидаги

Ўзбекистон Миллий кутубхонасининг

маданий, маърисрий, илмий-оммабоп

журнали, 2015 йилдан чиқа бошлаган

\section{ТАХРИР КЕНГАШИ:}

Умида Тешабаева - раис

\section{Кенгаш аъзолари:}

Асаджон Ходжаев - Ахборот ва оммавий

коммуникциялар агентлиги директори

Эркин Охунжонов т.ф..Д., просрессор

Аб дусалом Умаров соц. фр.д. профрессор

Марат Рахматуллаев т.фр.д., профрессор

Иброхим Йўлдошев фрил.фр.д. профрессор

Боқижон Тўхлиев фил. ф..Д. профрессор

Доно Зияева тарих т.фр.д. профрессор

Шамсиддин Камолиддин тарих фр.д. просрессор

Ғулом Нарзуллаев пед.фр.н

\section{ТАХРИР ХАЙЬАТИ:}

Аслиддин Жўраев - бош мухаррир

$$
\text { Хайъат аъsолари: }
$$

Раиса Ратнер

Давлетов Соибназар

Абадбой Қиличбоев

Вохид Хамидов тех.фр.н. доцент

Марина Ким - бош мухаррир ўринбосари

Зулхумор Иброхимова - мухаррир

Миразиз Мавлонов - мусаххих

Рўзмон Алимов - дизайнер

Отабек Жўраев - фотомухбир

\section{Нашр учун масъул}

Фаррух Мусаев

Босишга 30.12 .2020 йилпа рихсат Борипีи. Koғ оз формати 60х84 1/8. Нашриёт хисоб табоғи $8,7$. ИНДEKC 12T7 ISSN 2181-8207

Журнал 2015 йил 10 мартда Ўзбекистон матбуот ва ахборот агентлиги томонидан № 0846 рақами билан руйхатга олинган.

Журналдан кйчириб босилганда

«INFOLIB ахборот-кутубхона журнали»дан олинганлиги курсатилиши шарт.

Ушбу INFOLIB ахборот-кутубхона журнали тахририятининг компьютер марказида тайёрланди

Манзил: Тошкент шахри, Навоий кўчаси, 1 уй.

E-mail:infolibnl@gmail.com Сайт: www.einfollib.uz

$$
\text { Телефон: +99871 239-41-24 }
$$

Алишер Навоий номидаги

Узбекистон Миллий кутубхонасининг матбаа булимида чоп этилди Буюртма № 517. Адади 500 дона Тошкент шахри, Навоий кўчаси, 1 уй 


\section{КУТУБХОНАЧИЛИК СОХАСИДА ҚУВОНЧЛИ ВОҚЕА}

Ю ртимизда ёшларни бой маданий меросимизга бўлган қарашларини яна да такомиллаштириш ва уларни илм олишида беминнат ёрдамчи бўлган китобларнинг уурни беқиёсдир. Бу борада малакали кутубхоначиларнинг махорати ва билим салохияти мухим ахамият касб этади. Кейинги йилларда мамлакатимизда кутубхоначилик сохасида бир қатор қарорлар қабул қилиниши соха мутахассиларини янада юксак масъулият билан мехнат қилишларига замин яратмоқда.

«Инфолиб» журналининг аввалидаёқ, Сизларга кутубхоначилик сохасига қаратилган юксак эътироф - сохамиз вакилининг давлат мукофоти - «Мехнат шухрати» ордени билан тақдирланганлигини қувонч билан маълум қиламиз. Ўзбекистон Республикаси Президентининг 2020 йил 27 августдаги ПФ6051 фармонига куура, Ватанимиз мустақиллигини мустахкамлашга қўшган муносиб хиссаси учун хукуматимиз томонидан юксак мукосротларга сазовор бўлишди. 2020 йил 28декабр куни Кўксаройда мукофотларни топшириш маросими бўлиб ўтди. Улар орасида ўз касбининг жонкуяри, юртимиз кутубхоначилик сохаси ривожига катта хисса қўшиб келаётган, фридойи инсон Ўзбекистон Миллий кутубхонаси директори Тешабаева Умида Алимджановна хам борлиги, соха вакилларига катта ишонч билан бир қаторда халқимизнинг илмий-интеллектуал салохияти ва маънавиятини юксалтириш, таълим, маданият, адабиёт, санъатни ривожлантириш йўлида янада кўпроқ хизмат қилишга ундайди. Бу юксак мукофот республикамиздаги барча кутубхоначиларга ва кутубхоначи касбига бўлган эътиборнинг бир намунаси деб биламиз.

Дархақиқат, бугунги кунда республикамизда ахборот-кутубхона сохасини юқори босқичга кўтариш, ахолини ахборот олишини таъминлаш, хизмат кўрсатиш турларини кенгайтириш, китоб мутолаасига бўлган қизиқишни ўрганиш методларини ишлаб чиқиш, фойдаланувчиларига хизмат кўрсатиш сифати ва самарадорлигини ошириш, республика ахборот-кутубхона марказларига илмий-услубий ёрдам бериш, ёшларни интеллектуал билими ва савиясини оширишга қаратилган амалий ишлар орқали уларни кутубхоналарга жалб қилишда Умида Тешабаеванинг билими, кўп йиллик иш тажрибаси, талабчанлиги, хар ишга масъулият билан ёндашиши ва ташкилотчилигининг иородасидир.

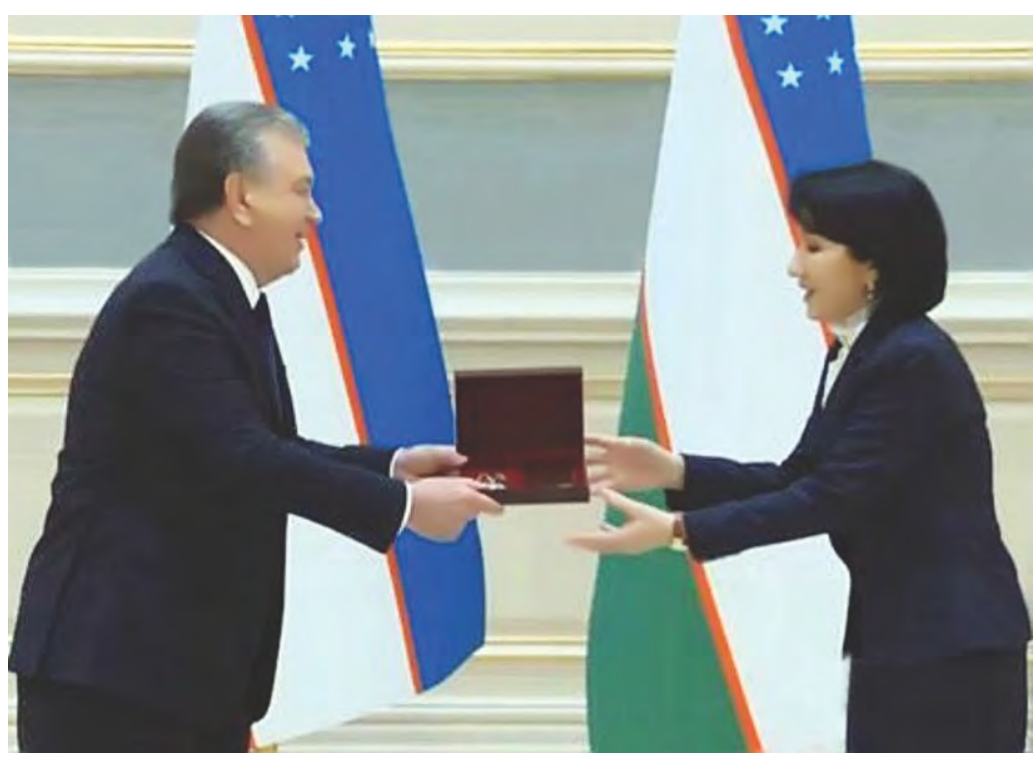

Ўзбекистон кутубхоначилиги сохасида фраолият олиб бораётган мутахассисларнинг қувончига сабаб бўлган яна бир воқеа - 2020 йилнинг ноябрь ойида Евроосиё кутубхоналар ассамблеяси (БАЕ)нинг XXIV умумий йиғилиши бўлиб ўтди. Ушбу конференцияда МДХ мамлакатлари кутубхоналарининг 2020- 2024 йилларда Евроосиё кутубхоналар ассамблеяси кенгашига ўтказилган сайловда Умида Тешабаева вице-президент этиб сайланди. Юксак ишонч, ўз навбатида, кутубхоначи мутахассисларимизда нафрақат фрахр туйғусини уйғотибгина қолмай, балки мамлакатимиз ахборот-кутубхоналарининг нуфузи жихатидан ривожланган хорижий кутубхоналар қаторига чиқаётганлигини намоён этмоқда. Бу бевосита билимли ва оридойи рахбарнинг ташаббускорлиги ва мехнатининг самарасидир.

Шунингдек, халқаро миқёсда хорижий давлатлар кутубхоналари билан меморандум тузиш, ўзаро тажриба алмашиш ва хамкорлик ишларини кенг йўлга қўйиб келмоқда.

Умида Алимджановна кутубхоначилик сохасида етук мутахассис сифратида республикада ахборот-кутубхона тизимини такомиллаштириш, сохани илмий тадқиқ қилиш, ходимлар малакасини ошириш ва қайта тайёрлаш, ахоли орасида китобхонликни кенг тарғиб қилишда жонбозлик кўрсатмоқда. Хукуматимиз томонидан кутубхоначиликка оид қонун ва қарорлар лойихаларини ишлаб чиқишда бевосита ўз таклифрарини киритиб кутубхоначилик ривожига катта хисса қўшиб келмоқда.

Биз барча кутубхона мутахассислари номидан юксак мукофот билан чин дилдан муборакбод этамиз! 


\title{
НАЦИОНАЛЬНАЯ
} БИБЛИОТЕКА УЗБЕКИСТАНА:

\section{из истории становления и современный этап развития}

\author{
(К 150-летию со дня основания \\ Национальной библиотеки Узбекистана)
}

\section{do $10.47267 / 2181-8207 / 2020 / 3-025$}

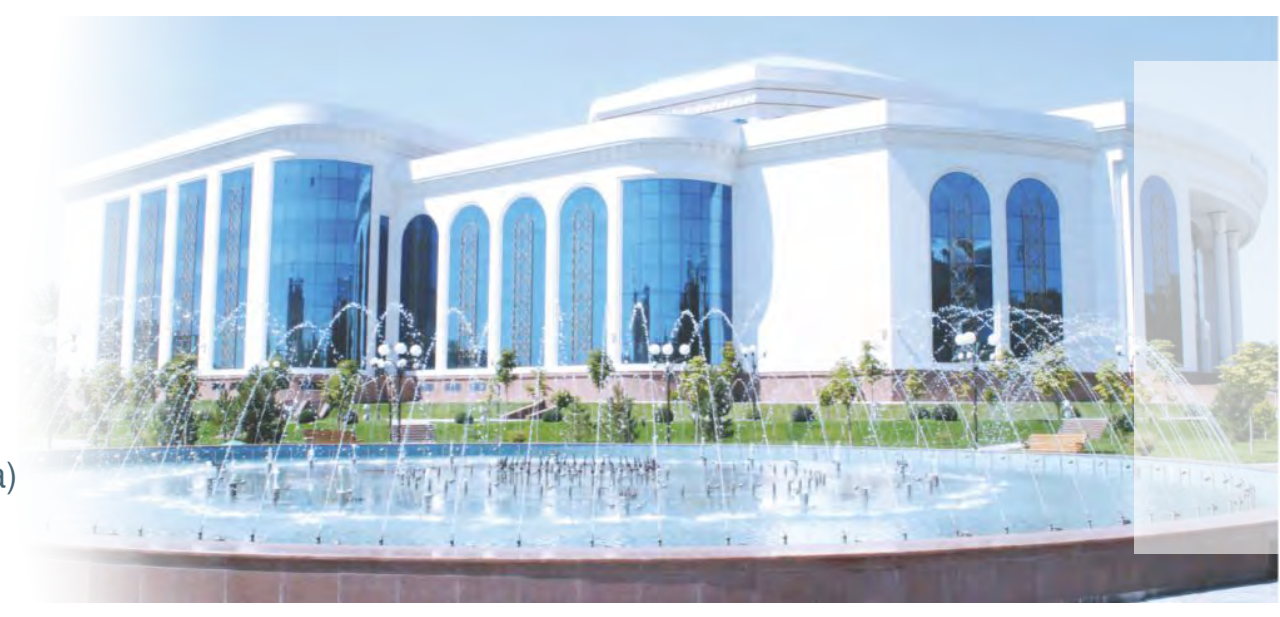

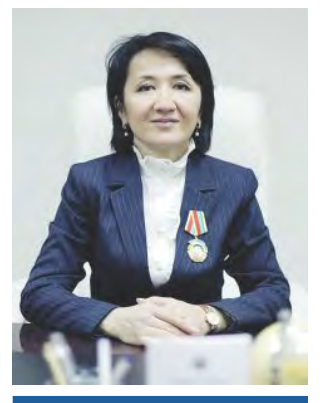

Умида Тешабаева, Директор

Национальной библиотеки

Узбекистана имени Алишера Навои

The article is devoted to the history of the Tashkent Public Library, at the origins of which were prominent scientists of that time, to the present day of the National Library of Uzbekistan. The library fund has more than 7.5 million items in 75 languages of the world. The National Library is the main methodological center of information and library institutions of the Republic. Creation of favorable conditions for readers is one of the priority tasks of the library, which is improved every year by the introduction of new technologies for obtaining information in an operational way. Thanks to membership in the International Consortium «elFL», users have access to 38 foreign educational databases, 12 of which are licensed. Also, library readers get access to national and world educational collections in different languages of the world.

Ключевые слова: Ташкентская публичная библиотека, отдел восточных рукописей, научноисследовательского учреждения, «Национальная неделя чтения», «Инфрормация для всех».

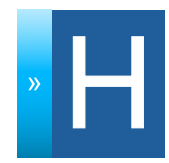
ациональнаябиблиотекаУзбекистана имени Алишера Навои сегодня является общегосударственным универсальным инорормационно-библиотечным учреждением, организующим и осуществляющим в Республике Узбекистан инорормационно-библиотечную деятельность в интересах развития национальной и мировой культуры, науки и образования.

Инфрормационно-библиотечный фонд насчитывает около 7 млн ед. изданий более чем на 75 языках мира и состоит из рукописей, книг, журналов, газет, диссертаций, авторефератов, нотно-музыкальных изданий, изданий по изобразительному искусству, аудиовизуальных материалов, электронных документов. На библиотеку возложена ответственная миссия постоянного хранения максимально полного информационно-библиотечного фонда страны.

C 2002 года в Национальной библиотеке Узбекистана находится уникальный фонд национальной печати, включающий свыше 3,5 млн ед. печатных изданий всех видов, хранящихся в Национальной книжной палате Республики Узбекистан. Значительное место в фонде (свыше 240,0 тыс. изданий), занимает литература научно-технического содержания: книги, периодические изда- ния и научные журналы ведущих издательств и агрегаторов научно-технической информации, получаемые по подписке таких компаний как eLibrary.Ru (Россия), Springer Nature (Германия), EBSCO Publishing (США), EBSCO Information Services $\mathrm{GmbH}$ » (Германия), ProQuest (США) и др как в традиционном, так и в электронном виде.

Благодаря членству в Международном консорциуме eIFL (Electronic Information for Libraries) библиотеке предоставляется доступ к 38 зарубежным общеобразовательным онлайн-базам данных, 12 из которых лицензионные. Пользователи библиотеки получают доступ к национальным и мировым образовательным коллекциям на разных языках мира, базам данных диссертаций, защищенных в Республике Узбекистан и за рубежом. В научном читальном зале библиотеки для ученых и исследователей предоставлен доступом к виртуальному читальному залу Российской государственной библиотеки, благодаря которому пользователи имеют возможность просматривать свыше 750 тысяч диссертаций и авторесрератов, защищенных в Российской Федерации. В 2013 году библиотека приобрела доступ к базе данных зарубежных журналов и газет со всего мира PressDisplay.com. 


\section{ИСТОРИЯ СТАНОВЛЕНИЯ}

Национальная библиотека Узбекистана имени Алишера Навои основана в 1870 году как Ташкентская публичная библиотека. Открытию предшествовали две заметки в газете «Туркестанские ведомости» (в №1 от 28 апреля и №2 от 21 мая 1870 года), но конкретной даты открытия библиотеки нигде не указано. Содействие в организации фонда оказали Министерство народного просвещения, Академия наук, Публичная библиотека, Географическое общество и Главный штаб России, пожертвовавшие дублетные издания из своих книгохранилищ. К маю 1870 года было собрано более 2200 томов (1200 названий), составивших книжное ядро будущей библиотеки.

Ташкентская публичная библиотека собирала и хранила литературу по разным отраслям знаний, в первую очередь связанную с краем и сопредельными странами. Для проведения этой работы привлекли российского библиографра Владимира Измаиловича Межова. Он осуществил сбор материалов о Туркестанском крае, которые положили начало созданию широко известного в научных кругах «Туркестанского сборника».

В 1883 году был создан «Наблюдательный комитет». В его состав в разные годы входили известные ученые, педагоги, историки, этнографы Н.А. Маев, Н.В. Дмитровский, А.А. Семенов, А.А. Диваев, Н.Г. Малицкий и др. Комитет оказал неоценимую помощь развитию библиотеки. В этот период был создан известный «Туркестанский альбом», один из богатейших источников наглядной инорормации о культурных памятниках Средней Азии в том виде, как они существовали в XIX веке. Составление этого уникального фотоальбома поручили ориенталисту Александру Людвиговичу Куну.

В 1920 году библиотеке присвоен статус «государственная». С этого года библиотека начинает получать обязательные экземпляры всех изданий, выходящих в свет на территории Туркестанского края. В 1925 году фонд библиотеки составлял 140 тыс. единиц хранения.

Вследствие размежевания республик Средней Азии библиотека осталась в подчинении Наркомпроса Узбекистана и оказывала практическую помощь вновь созданным Среднеазиатским республикам в организации библиотечного дела.

В июле 1925 года при восточном отделе
Государственной публичной библиотеки Узбекистана начал функционировать институт практикантов, в декабре 1929 года открылись курсы изучения узбекского языка, созданные для сотрудников библиотеки, в августе 1930 года - курсы подготовки каталогизаторов научных библиотек, в январе 1932 года - трехмесячные курсы по каталогизации, систематизации и предметизации, а в октябре 1934 года при Комитете наук - курсы для работников научных библиотек.

Решением правительства Узбекистана Государственная публичная библиотека в Ташкенте в 1933 года объявлена Центральным хранилищем восточных рукописей республики. Отдел восточных рукописей возник одновременно с основанием Ташкентской публичной библиотеки в 1870 году, но рос крайне медленно. Почти через двадцать лет (1889г.) собрание рукописей Ташкентской публичной библиотеки составляло всего 87 томов. В 1895 году в статье по поводу 25-летия библиотеки, Николай Васильевич Дмитровский писал: «Библиотека насчитывает свыше 90 томов рукописей на восточных языках». «Каталог рукописей Туркестанской публичной библиотеки» за 1912 год включает 231 рукопись, причем сюда входит состоявшее из 194 рукописей собрание руководителя андижанского восстания минтюбинского ишана Мухаммеда Али Сабирова, конфискованное царским правительством и переданное в 1898 году библиотеке.

В следующие годы ситуация с приобретением литературы не изменилась, так как библиотека не имела фринансовой возможности для покупки рукописей. Комплектование шло за счет пожертвований рукописей и покупок единичных экземпляров «по дешевке». Только после 1917 года пополнение рукописных фондов библиотеки начало развиваться.

С 1918 года Государственная публичная библиотека получила возможность приобретать не только отдельные рукописи, но и целые собрания в сотни томов. Таким образом, были приобретены такая исключительная по своей ценности коллекция, как собрание рукописей последнего бухарского «верховного судьи» Шарифджана-махдума, собрание В.Л. Вяткина и др. В те годы в отдел восточных рукописей публичной библиотеки были переданы замечательные собрания рукописей Научно-исследова-
В 1920 году

библиотеке

присвоен статус

«государственная».

С этого года

библиотека

начинает получать обязательные экземпляры всех изданий, выходящих в свет на территории Туркестанского края

Решением правительства

Узбекистана Государственная публичная библиотека в

Ташкенте в 1933 года объявлена Центральным хранилищем восточных рукописей республики 
В конце 1930-х гг.

Государственная публичная биб-

лиотека стала

подлинным методическим центром для других

библиотек республики, численность которых к тому времени превысила 2,5 тыс.

В 1948 г.

библиотеке было

присвоено

имя великого

узбекского поэта

и мыслителя

Алишера Навои и

открылось новое

трех-этажное

здание с

читальными

залами

на 350 мест тельского института города Самарканда, библиотеки имени Ибн Сины города Бухары, библиотеки Хивинских ханов и некоторых других. Это дало возможность сосредоточить в одном месте большое рукописное собрание, отражающее запросы среднеазиатского общества примерно за 700летний период, а также памятники письменности почти за 1000 лет существования «мусульманской культуры» (старейшая рукопись на арабском языке датируется 344/955 годом, а позднейшие списки восходят к нашему времени).

В 1943 году все рукописи, приобретенные библиотекой или принятые в дар из личных собраний, по распоряжению правительства были переданы в Институт востоковедения Академии наук Республики Узбекистан для более полного и детального их изучения учеными.

Большое значение в работе библиотеки в 1920-1930-е гг. имела библиографрия. В этот период сотрудниками созданы крупные библиографические труды. В конце 1930-х гг. Государственная публичная библиотека стала подлинным методическим центром для других библиотек республики, численность которых к тому времени превысила 2,5 тыс. Открылся при ней кабинет библиотековедения и библиографии, где постоянно проводились лекции, обзоры, консультации.

В годы Второй мировой войны в залах библиотеки работали академики В.В. Струве и В.П. Филатов, члены-корреспонденты Академии наук СССР В.М. Жирмунский, А.Ю. Якубовский, Н.К. Пиксанов, писатели А.Н.Толстой, Н.Е. Вирта, Вс.В. Иванов, М.А. Цявловский, В.Г. Ян, К.И. Чуковский, работники искусств - заслуженный деятель искусств М.Ф. Гнесин, профессор В.М. Беляев, композитор Н.В. Богословский, народный артист СССР И.В. Ершов и многие другие, эвакуированные в Ташкент. В послевоенное время главной задачей библиотеки становится пополнение книжных фрондов. Начали поступать книги из Болгарии, Венгрии, ГДР, Польши, Румынии, Чехословакии. Налаживались дружеские связи с библиотеками Великобритании, США, Франции, ФРГ, Японии.

В 1948 г. библиотеке было присвоено имя великого узбекского поэта и мыслителя Алишера Навои и открылось новое трехэтажное здание с читальными залами на 350 мест. В 1970-е гг. создаются новые от- делы-научно-исследовательский, научной информации по культуре и искусству, депозитарного хранения, контрольно-диспетчерской службы, юношеский.

Особое внимание стало уделяться пополнению фонда литературой на узбекском языке. Сейчас в нем свыше 600 тыс. экз. произведения классиков узбекской литературы, таких как Навои, Фуркат, Мукими, Завки, Ибн Сино (Авиценна), Улугбек, Бируни, а также работы современных ученых и писателей республики.

\section{СОВРЕМЕННЫЙ ЭТАПВ РАЗВИТИИ}

Обретение Узбекистаном независимости привело к возрождению духовных и исторических ценностей, народных традиций и обычаев, древней истории и культуры, родного языка. В практику работы Национальной библиотеки вошли такие фрормы массовых мероприятий, как читательские конореренции, творческие встречи, вечера, посвященные великим просветителям и ученым Востока. Появились и новые фрормы изданий, такие как дайджесты, фрлайеры, буклеты, информационные листы и т.д.

Важный этап в истории становления библиотеки связан с утверждением в 2002 году Указа Президента Республики Узбекистан «О совершенствовании организации научно-исследовательской деятельности», согласно которому принято предложение научныхучреждений и ведомств республики о создании Национальной библиотеки Узбекистана имени Алишера Навои путем объединения Государственной библиотеки Республики Узбекистан имени Алишера Навои и Республиканской научно-технической библиотеки с подчинением ее Кабинету Министров Республики Узбекистан. Это решение было принято в целях расширения деятельности библиотеки как центра национальной культуры, сокровищницы национального духовного наследия народа Узбекистана и дальнейшего развития библиотечного дела в республике.

В этом же году было принято Постановление Кабинет Министров Республики Узбекистан «О создании Национальной библиотеки Узбекистана имени Алишера $\mathrm{Ha}$ вои». Постановление определило статус библиотеки - главного государственного книгохранилища национальной и зарубежной печати, многофрункционального информационно-библиотечного и научно-исследо-вательского учреждения, методическо- 
гоцентра для всех библиотек республики.

Принимая во внимание возросшую значимость инорормации и роль Национальной библиотеки Узбекистана, по инициативе Первого Президента Республики Узбекистан И. Каримова, в 2010 году началось проектирование и строительство нового здания Национальной библиотеки Узбекистана, которая открыла свои двери для пользователей в декабре 2011 года. Для библиотеки было построено новое здание в центре Ташкента, располагающееся в архитектурном комплексе «Маърифрат маркази». Цель строительства - создание необходимых условий, направленных на удовлетворение инфрормационных, научно-образовательных и культурных потребностей населения, особенно молодежи, с использованием современных информационнокоммуникационных технологий. Общая площадь нового здания составляет 38 тыс.кв.м. и включает основные производственные зоны, зоны обслуживания читателей, помещения для хранения фондов и зал для проведения международных симпозиумов.

С выходом Постановления Президента Республики Узбекистан в 2012 года “О мерах по организации деятельности Национальной библиотеки Узбекистана имени Алишера Навои - инсрормационного ресурсного центра» обновлена структура библиотеки, расширился круг задач. Большое внимание сегодня уделяется организации универсального доступа к образовательной инфрормации в целях развития специалистов высшей квалифрикации, упрочения и популяризации знаний у молодежи, создания необходимых условий для привлечения ее к научной деятельности с использованием новых инсрормационных технологий.

Национальная библиотека ответственна за присвоение Международного стандартного номера книги (ISBN) и Международного стандартного номера сериального издания (ISSN). В 2013 году по заказу библиотеки была разработана программа «ISBN\&ISSN" для присвоения ISBN и ISSN номеров в онлайн-режиме (через web-сайт www.natlib.uz библиотеки).

В библиотеке функционирует музей книги, в котором демонстрируются уникальные рукописи и книги, изданные литографическим способом. В их числе труды Абул Хасана ал-Моварди «Основы государственности» (XI век н.э.), Махмуда аз-Замахшари

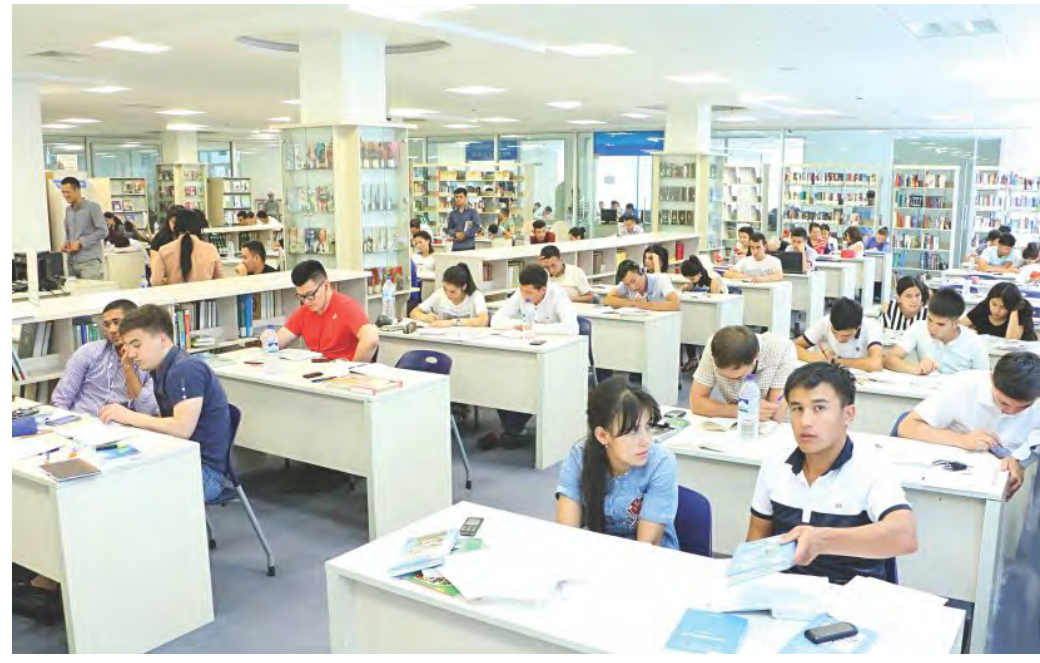

«Мукаддимат ул-адаб» (1308 г. н.э.), Алишера Навои «Девон» и др. Все экспонаты представлены из коллекции редких и рукописных изданий библиотеки, которые хранятся в фронде службы «Рукописей, уникальныхи особо ценных изданий».

Распоряжение Президента Республики Узбекистан «О создании комиссии по развитию системы издания и распространения книжной продукции, повышению и пропаганде культуры чтения» и Постановление Президента Республики Узбекистан «О программе комплексных мер по развитию системы издания и распространения книжной продукции, повышению культуры чтения", утвержденные в 2017 году определили дальнейшее развитие инфрормационнобиблиотечной сореры от 13 сентября 2017 года направлено на комплексное решение проблем, возникшихв данной области.

В соответствии с постановлением Узбекское агентство по печати и инсрормации было определено специально уполномоченным государственным органом в области совершенствования печати и распространения книг, а также инфрормационно-библиотечной деятельности.

Согласно Указу Президента Республики Узбекистан «О мерах по дальнейшему совершенствованию сфреры инорормационных технологий и коммуникаций» в 2018 году Республиканский инсрормационно-библиотечный центр, инфрормационно-библиотечные центры Республики Каракалпакстан, областей и города Ташкента были переданы в ведение Национальной библиотеки Узбекистана имени Алишера Навои Узбекского агентства по печати и инфрормации.

В 2019 году главой нашего государства

\section{в 2010 году \\ началось}

проектирование и

строительство

нового здания

Национальной

библиотеки

Узбекистана, которая открыла свои двери для пользователей в декабре

2011 года 
было выдвинуто пять важных инициатив по молодежной политике, имеющих историческое значение, организующих работу в социальной, духовно-просветительской сорерах на основе новой системы. Вопросы ор-

Вопросы

организации системной работы

по повышению

духовности молодежи, широкой пропаганде чтения книг среди населения республики были закреплены

в 4-й инициативе

Президента

Ш. Мирзиёева

Научнометодическая деятельность Национальной

библиотеки

Узбекистана

определяется ее историческим становлением,

неразрывно связана со всеми этапами истории нашей страны ганизации системной работы по повышению духовности молодежи, широкой пропаганде чтения книг среди населения республики были закреплены в 4-й инициативе Президента Ш. Мирзиёева. В целях реализации данной инициативы были разработаны следующие проекты: «Читаем в пути», «Встреча с любимым писателем», «Оживляем героев книг», «Национальная неделя чтения», «Я успешная женщина» и др.

Постановление Президента Республики Узбекистан «О дальнейшем совершенствовании информационно-библиотечного обслуживания населения Республики Узбекистан» было принято специалистами инфрормационно-библиотечной сфреры как основополагающий документ в формировании качественно новой системы инорормационно-библиотечного обслуживания населения. Благодаря широкому внедрению информационно-коммуникационных технологий появилась возможность свободного доступа социально уязвимых слоев населения к национальным ценностям и мировой культуре, практическим и фрудаментальным знаниям, хранящимся в инфрормационно-библиотечных учреждениях республики.

В соответствии с этим документом в республике были организованы районные (городские) инорормационно-библиотечные центры. В их распоряжение переданы фонды инорормационно-ресурсных центров закрывшихся колледжей, выделены штатные единицы, созданы качественно новые и комфортные условия для информационно-библиотечного обслуживания населения.

В связи с вновь созданными в стране информационно-библиотечными центрами в Национальной библиотеке Узбекистана организована новая служба. В настоящее время, используя сайты и информацию о текущей деятельности региональных информационно-библиотечных учреждений в открытом доступе, сотрудники службы координации и мониторинга региональных информационно-библиотечных центров и специалисты научно-методической службы ведут совместную аналитическую, исследовательскую, статистическую и мониторин-

говую деятельность, направленную на дальнейшее успешное развитие информационно-библиотечныхучреждений.

\section{НАУЧНО-МЕТОДИЧЕСКАЯ}

\section{ДЕЯТЕЛЬНОСТЬ}

Перелистывая страницы истории главной библиотеки страны, хочется остановиться на тех людях, которые стояли у истоков научно-методической деятельности. Имена многих сотрудников библиотеки, внесших большой вклад в развитие библиотечного дела Узбекистана, известны не только в нашей стране, но и за ее пределами. Среди них М. Латыпова, Т. Егорова, И. Пугач, Г. Бертман, И. Маминова, А. Умаров. Какие бы изменения ни претерпевала методическая служба, в ней всегда работали профрессионалы, энтузиасты, новаторы.

Научно-методическая деятельность Национальной библиотеки Узбекистана определяется ее историческим становлением, неразрывно связана со всеми этапами истории нашей страны.

Специалисты библиотеки не только инициировали разработку законопроектов «Об инорормационно-библиотечной деятельности», «Об обязательном экземпляре изданий, национальных библиотечных стандартов, регламентирующих деятельность инорормационно-библиотечных и информационно-ресурсных центров, Концепции и Программы развития инорормационнобиблиотечного дела в республике, но и вошли в состав рабочих групп по этой тематике.

С 2013 года специалисты Национальной библиотеки Узбекистана принимают участие в создании положения «Об электронном фронде уникальных и особо ценных информационно-библиотечных ресурсов». В 2014 году специалистами научно-методического отдела разработан и переработан текст положения «Об инорормационно-библиотечном обслуживании пользователей Национальной библиотеки», а также инструкции республиканского значения «О порядке исключения информационно-библиотечных ресурсов из фрондов инсрормационно-библиотечных учреждений» и «О сохранности инфрормационно-библиотечных фрондов инорормационно-библиотечныхучреждений».

В 2015 году методисты Национальной библиотеки Узбекистана приняли активное участие в организации и проведении цикла мероприятий по дальнейшему повышению 
медиаграмотности молодежи при общении в социальных сетях и формирования у них этики пользования информацией в сети Интернет на темы: «Информационная атака и защита от нее», “Средства массовой информации современных информационных услуг, фрормы и методы работы с общественными и политическими организациями», «Киберпреступность и защита личности от ее угрозы», «Формирование медиаграмотности у молодежи при общении в социальных сетях и этики пользования инфрормацией в сети Интернет», «Роль социальных сетей в фрормировании духовного иммунитетамолодежи» и др.

В рамках проекта «Формирование информационной культуры и медиаграмотности специалистов информационно-библиотечных учреждений Узбекистана в период углубления реформ в информационно-библиотечной сорере» специалисты Национальной библиотеки Узбекистана, совместно с Представительством ЮНЕСКО в Узбекистане и Министерством народного образования Республики Узбекистан, организовали учебные курсы по формированию инфрормационной культуры и медиаграмотности для 70 специалистов информационно-библиотечной сореры.

В этом же году специалисты научно-методического отдела Национальной библиотеки при участии ЮНЕСКО организовали учебный семинар по изучению объектов документального наследия для включения в программу ЮНЕСКО «Память мира». В рамках мероприятий, проведенных в Национальной библиотеке Узбекистана по изучению объектов документального наследия для включения в программу ЮНЕСКО «Память мира», были обсуждены вопросы привлечения СМИ в работу программы «Память мира», издание общедоступной инорормации, продвижение программы в среду широкой общественности.

\section{МЕЖДУНАРОДНАЯ ДЕЯТЕЛЬНОСТЬ}

Международная деятельность Национальной библиотеки направлена на создание условий по развитию сотрудничества и взаимодействия между библиотекой и национальными библиотеками, ведущими информационными, образовательными и научными учреждениями зарубежных стран. В частности, ведется работа по развитию международного документообмена, обслуживанию в рамках международного меж-

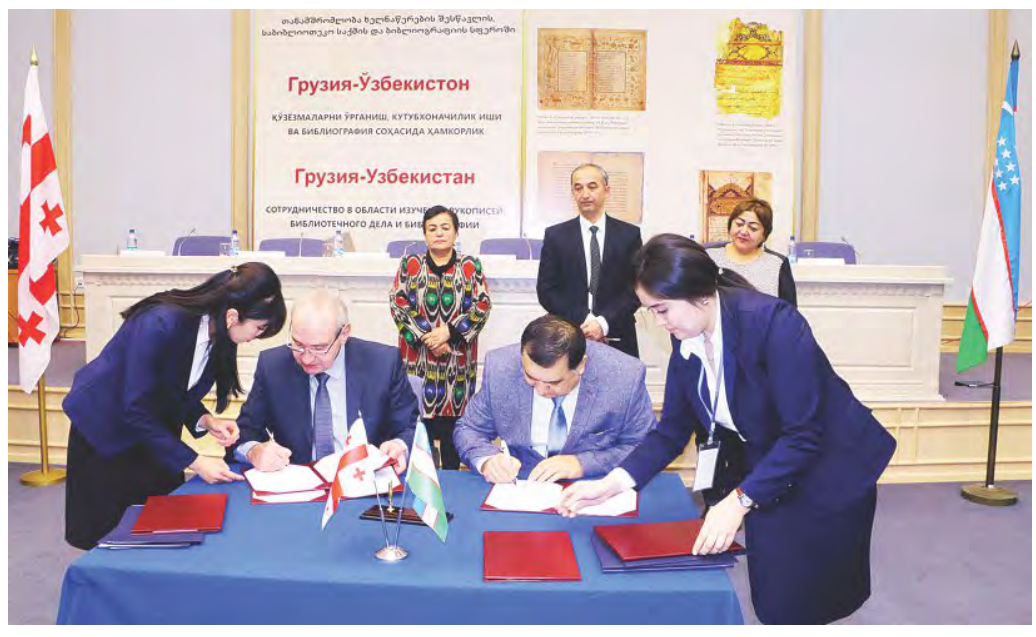

библиотечного абонемента.

Библиотека подписала соглашения и меморандумы о сотрудничестве с Национальными библиотеками таких стран, как Китай, Иран, Корея, Азербайджан, Латвия, Россия, Беларусь, Казахстан, Кыргызстан, Турция, Чехия, с Японским университетом искусства Аичи, Региональным Центром ИФЛА / РАС по Центральной Азии, Гёте институтом в Узбекистане, Национальным центром рукописей Грузии имени Корнели Кекелидзе, Государственной библиотекой Государственного культурного центра Туркменистана, Азербайджанской национальной библиотекой имени М.Ф. Ахундова, с Посольством Соединенных Штатов Америки в Республике Узбекистан и др.

Успешно проводятся совместные проекты «Окно в Корею», «Окно в Шанхай», «Окно в Америку», функционирует «Центр казахстанской литературы и культуры» и «Зал знаний ШОС» Центра народной дипломатии ШOC.

Активно осуществляется взаимодействие библиотеки с международными организациями, особенно с Национальной комиссией по делам ЮНЕСКО в Республике Узбекистан, при поддержке которой успешно реализован целый ряд проектов: Программа «Информация для всех», программа «Память мира», проект «Основы инфрормационной культуры»

\section{ЗНАЧИМЫЕ МЕРОПРИЯТИЯ}

Активизация деятельности информационно-библиотечных учреждений, учебных заведений, архивов, музеев и других организаций для действенного и результативного сотрудничества в развитии и применении электронных инорормационно-библиотечных ресурсов в науке, образовании,
Успешно

проводятся

совместные

проекты «Окно

в Корею», «Окно

в Шанхай», «Окно

в Америку»,

функционирует

«Центр

казахстанской

литературы и

культуры» и «Зал

знаний ШОС»

Центра народной

дипломатии шОС 
Национальная

библиотека

Узбекистана, начиная с 1999 года проводит международ-ную конференцию "Central Asia», начиная с 2012

года ежегодно проводит

Национальную инорормационно-

библиотечную неделю «INFOLIB»

Национальная библиотека

Узбекистана это не только источник инфоомации, а важнейший элемент национального самосознания и общечеловеческой культуры культуре и бизнесе имеет приоритетное значение.

Национальная библиотека Узбекистана, начиная с 1999 года проводит международную конференцию «Central Asia», начиная с 2012 года ежегодно проводит Национальную инорормационно-библиотечную неделю «INFOLIB», миссия которой - усиление у пользователей стремления и интереса к самостоятельному получению информации, подробное ознакомление с новоизданной общественно-политической, научно-просветительской, учебной и художественной литературой.

Популяризация чтения, повышение уровня инорормационной культуры и сохранение культурного наследия, повышение возможностей Интернета в трансорормации инорормационно-библиотечного обслуживания пользователей, разработка и внедрение современных инновационных и образовательных технологий, повышение социально-культурной роли информационно-библиотечных учреждений в организации обслуживания различных категорий населения - приоритетные направления информационно-библиотечных учреждений Республики Узбекистан.

С целью повышения качества научных исследований и публикационной активности в Республике Узбекистан, Национальная библиотека инициировала проведение $\mathrm{Ha}$ ционального научно-образовательного форума «Доступ к научной информации и публикационная активность». Впервые в библиотечной практике был организован коллективный доступ к научно-образовательным базам данных EBSCO для 120 учебных, научных и инфрормационно-библиотечных учреждений республики.

\section{ЗАКЛЮЧЕНИЕ}

Национальная библиотека Узбекистана по составу своих фондов, уровню технологий, квалисрикации сотрудников отвечает требованиям сегодняшнего дня. Прогнозируя роль и место библиотеки, можно с уверенностью сказать, что Национальная библиотека Узбекистана - это не только источник информации, а важнейший элемент национального самосознания и общечеловеческой культуры. Библиотека продолжает выполнять функции национального социокультурного института, участвует в фрормировании мировоззрения, духовном обогащении народа республики.

Богатые исторические традиции, бережно сохраняемые коллективом единомышленников, новаторские идеи, постоянное стремление идти вперед, притягивают к библиотеке внимание всей информационно-библиотечной общественности. Являясь культурным центром, библиотека вносит весомый вклад в развитие культуры, науки, образования Республики Узбекистан, в дело возрождения и сохранения исторических, национальных и духовных ценностей узбекскогонарода.

Можно с уверенностью сказать, что Национальная библиотека - это информационно-библиотечное учреждение нового поколения, оптимизированное на удовлетворение индивидуальных потребностей пользователей и использующее в своей работе наиболее прогрессивные технологии, которые являются необходимым связующим звеном между библиотекой и пользователем, обеспечивая тем самым тесную взаимосвязь культуры, образования, науки.

\section{Умида Тешабаева - Алишер Навочй номидаги Ўзбекистон Миллий кутубхонаси дирек- mори. \\ Мақола Ўзбекистон Миллий кутубхонасининг ташкил этилганлигининг 150 йиллиги-} га бавишланган бўлиб, хозирги вақтда умумий фонди 7,5 млн. босма нашрлардан ташкил топган ва жахоннинг 75 тилида сўзлашувига эга бўлган китобхонларнинг фойдаланищлари учун кулай шароитлар мавжудлиги хақида маълумот беради. Бунинг мисоли сифатида Миллий кутубхона халқаро еIFL консорциумига доимий абзо сифатида 38 та хорижий илмий-таблимий маълумотлар базасига кириш имконияти яратилганганлиги, улардан 12 таси эса лицензияли электрон базалардир. Бугунги кунда кутубхона ўз фойдаланувчиларига янада кулай имкониятлар яратиб бериш мақсадида барча мутахассисларга креатив ёндашув асосида улар олдига замонавий технологияларни татбиқ, этган холда хизмат кўрсатиш юклатилганлиги таъкидлананди. Шу билан бирга, кутубхона республикадаги барча ахборот-кутубхона муассасалари учун хам методик марказ хисобланади.

Бундан ташқари муаллиф кутубхона тарихига оид Тошкентда оммавий кутубхона ташкил қилинишида Туркистон ўлкасида фаолият олиб борган бир қанча таниқли зиёлиларнинг қушшган хиссалари х,ақцда хам батафсил тўхталиб ўтган. 


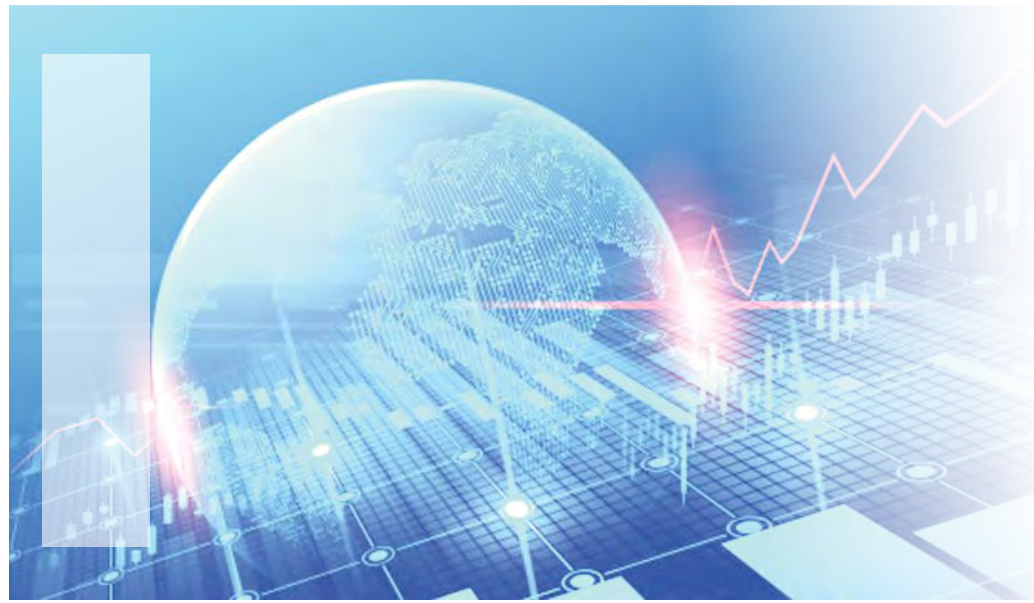

\section{НОВОСТИ ИНФОРМАЦИОННО- БИБЛИОТЕЧНОЙ СФЕРЫ В МИРЕ}

\section{ИФЛАПУБЛИКУЕТ КОНТРОЛЬНЫЙ ПЕРЕЧЕНЬ ЗАКОНОВ ОБ ОБЯЗАТЕЛЬНОМ ЭКЗЕМПЛЯРЕ}

ИФЛА выпустила свой контрольный спиСок для законов об обязательном экземпляре, чтобы помочь тем, кто анализирует существующие законы или планирует новые. Он предназначен для того, чтобы ключевые проблемы или вопросы не были забыты, а были включены в размышления об этой ключевой области законодательства для библиотек и их пользователей.

Национальные библиотеки и другие учреждения с фрункциями обязательного экземпляра играют жизненно важную роль в обеспечении сохранности документального наследия, а также в поддержке других целей, представляющих общественный интерес.

Они вносят свой вклад, как библиотеки последней инстанции для исследователей, источники исторических материалов для поддержки образования, а также посредством своей поддержки в создании национальных библиографий, а иногда и в управлении ISBN.

Во многих случаях их деятельность строго основана на законах об обязательном экземпляре, которые создают возможность получать или собирать копии всех произведений, опубликованных в стране.

В них изложены обязанности и возможности для библиотек и издателей информации, в том числе в отношении общих целей, какие произведения охватываются, как произведения должны быть депонированы или собраны и что библиотеки могут впоследствии с ними делать.

С появлением новых фрорматов публикации, беспрецедентных объемов контента и новых возможностей использования, те, кто занимается обязательным экземпляром, мо- гут столкнуться с важными вопросами.

Существующие законы могут не охватывать новые виды работ или не предлагать ясности, создавая неопределенность как для производителей, так и для учреждений обязательного депонирования. Возможно, они также не были обновлены для отражения новых технологических возможностей обеспечения безопасного доступа.

Новый Контрольный список ИФЛА для законов об обязательном экземпляре призван предоставить инструмент для тех, кто анализирует существующие законы или планирует новые.

\section{ВДОХНОВЛЯЮЩИЕ ЗДАНИЯ \\ БИБЛИОТЕКИ:НОВЫЙ АККАУНТ \\ B INSTAGRAM ВАМ ОБЯЗАТЕЛЬНО ПОНРАВИТСЯ!}

\section{История подразделения.}

Секция зданий и оборудования библиотеки включает библиотекарей и архитекторов, увлеченных дизайном и технологиями библиотек. Группа стремится делиться инорормацией о библиотечных зданиях и оборудовании, чтобы расширить профессиональные знания и способствовать совершенствованию библиотечного дизайна.

Проект направлен на демонстрацию множества библиотек, больших и малых, во всех частях мира, включая как менее известные, так и известные библиотеки. Помимо новых библиотечных зданий, в проекте также будут представлены переоборудованные здания и реконструкция.

Из-за визуального характера этой инициативы секция выбрала Instagram в качестве предпочтительного канала для продвижения вдохновляющих библиотек и поддержки их усилий по охвату глобальной аудитории. Создана новая учетная запись Instagram с дес-

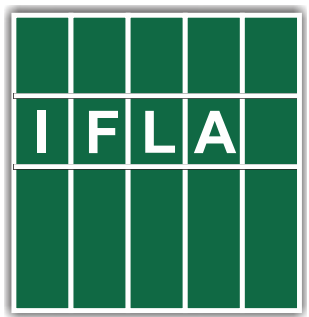

Новый

Контрольный список ИФЛА

для законов об обязательном экземпляре

призван предоставить инструмент для тех, кто анализирует существующие законы или планирует новые 


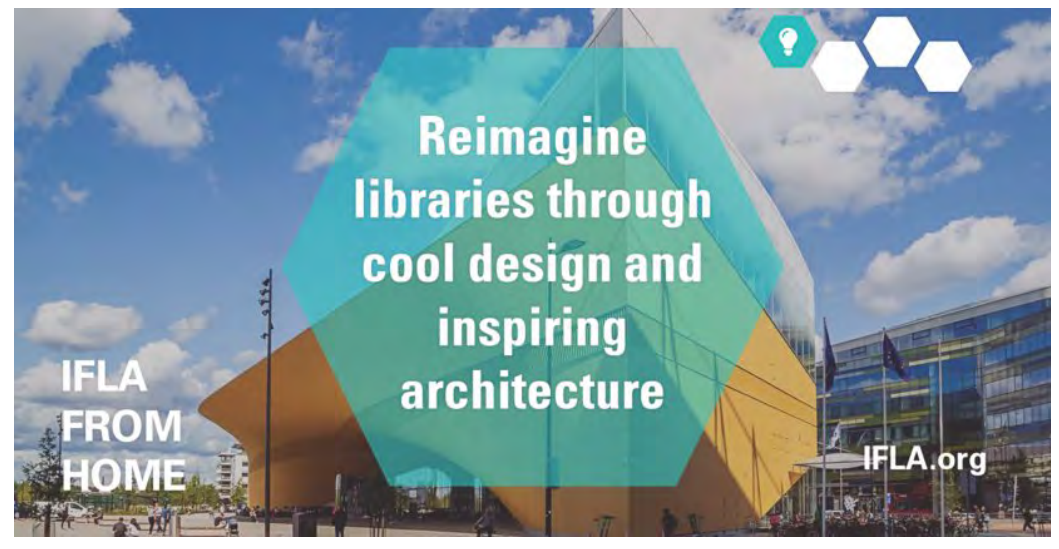

криптором ifla_lbes_inspiringlibraries. Проект был запущен с первого поста в конце сентября 2020 года и быстро завоевал интерес в библиотечном мире с более чем 100 подписчиками за первые два дня!

В первом посте была представлена библиотека Ооди в Хельсинки, Финляндия - победитель престижной премии IFLA / Systematic Public Library of the Year 2019. Посты намеренно выбраны для перемещения по миру, демонстрируя различные типы библиотек. По мере продвижения проекта последователи могут ожидать вдохновения от удивительной библиотечной архитектуры, передовых технологий и превосходного дизайна, которые создадут новые способы мышления о библиотечных пространствах.

\section{ФОРУМПОУПРАВЛЕНИЮ \\ ИНТЕРНЕТОМ 2020: \\ ВЫВОДЫ ДЛЯ БИБЛИОТЕК}

IGF 2020 года - первый форум, проходящий в полностью виртуальном формате. В ходе более 250 онлайн-сессий многие поднятые вопросы актуальны для глобального библиотечного сектора.

В рамках двухнедельной программы ИФЛА приняла участие в обсуждениях на Форуме управления Интернетом (IGF - или vIGF, что означает виртуальный (GF), работая над тем, чтобы осветить работу и потенциал библиотек в преодолении цифрового разрыва, выявить и отстаивать политику поддержки среды, и проанализировать текущие проблемы и проблемы управления Интернетом.

\section{Как мир продвинулся с внедрением цифровых технологий?}

Этот год ознаменовался тревожной вехой - несмотря на то, что одна из задач Целей в области устойчивого развития заключается в обеспечении всеобщего и доступного досту- па к Интернету в наименее развитых странах к 2020 году, глобальное использование Интернета по-прежнему оценивается лишь примерно 57\% населения мира, при этом всего $23 \%$ населения наименее развитых стран находятся в сети.

Поэтому одно из направлений IGF в этом году - «Инклюзия» - было сосредоточено на задачах привлечения большего числа людей в Интернет.

В целом, существует широкое согласие относительно срочности подключения большего числа людей. Чтобы помочь в достижении этого, мощный потенциал могут иметь дополнительные поставщики и альтернативы традиционным коммерческим интернет-услугам.

Как было подчеркнуто на заседании «Динамической коалиции за публичный доступ в библиотеках», библиотеки могут быть ценным инструментом, помогающим осуществить такое вмешательство. Среди выводов этого заседания спикеры подчеркнули важность:

- инвентаризация как доступной (библиотеки и возможности подключения) инфраструктуры, так и ресурсов и потребностей сообщества;

- ускоренное развертывание инораструктуры, которая помогает подключать приоритетные конечные точки, такие как библиотеки, что, в свою очередь, может привлечь больше людей в Интернет;

- и развитие навыков и потенциала библиотечного персонала, чтобы они могли предлагать решения равного доступа для своих сообществ.

\section{Равный интернет?}

Уязвимые и маргинализированные социальные группы особенно пострадали от быстрой оцифровки общества, связанной с пандемией, что усугубляет существующее цифровое неравенство.

Например, многое еще предстоит сделать для обеспечения доступности для людей с ограниченными возможностями. Хотя было указано, что Марракешский договор оказал решающее влияние на доступ к информации для людей с ограниченными возможностями зрения и восприятия печатной инсрормации, необходимо сделать гораздо больше для обеспечения доступа для людей с различными видами инвалидности.

Доступ к местному, актуальному и высококачественному контенту является важным элементом значимого цифрового включения. IGF предложил платформу, чтобы подчеркнуть, что срочно необходимы поддерживаю- 
щие политики и практики - от решения вопросов, связанных с ценообразованием на электронные книги, до исключений и ограничений авторского права, готовых к цифровой обработке.

Без этого доступ к качественному цифровому контенту может стать еще одним аспектом цифрового исключения, который усиливает существующее неравенство, поскольку меньшее количество людей может позволить себе получить доступ к качественным материалам в Интернете.

Цифровые навыки, как всегда, были подтверждены в качестве еще одного ключевого аспекта цифровой интеграции, при этом в ходе этого IGF были подчеркнуты различные важные навыки и возможности. Помимо традиционных навыков в области ИКТ, различные участники подчеркнули критическое мышление, знания и понимание пользователями своих прав в Интернете, навыки участия в цифровой онлайн-экономике.

В этом году в ходе обсуждений снова были отмечены опасения по поводу дезинформации, в том числе тревожные тенденции дезинформации, касающиеся COVID, избирательных процессов и изменения климата.

Онлайн-образование также занимало важное место в повестке дня IGF в этом году: на нескольких сессиях изучается опыт студентов и преподавателей в области быстрого перехода на цифровые технологии во время пандемии. Некоторые из общих (и серьезных) проблем, с которыми сталкиваются во всем мире, включают не только отсутствие доступа к Интернету или соответствующих устройств для учащихся и цияровых навыков (как учащихся, так и учителей), но также, как было указано в одном из сессий, необходимость социальной инфраструктуры, поддерживающей онлайн-образование. Это говорит о таких проблемах, как трудности учащихся с концентрацией или мотивацией, или о необходимости поддержки родителей или учителей.

Инновации в онлайн-образовании и обучении. Другой момент, подчеркнутый некоторыми участниками дискуссии, заключался в том, что простой перенос традиционных занятий в классе в онлайн-среду может не дать наиболее эффрективных результатов. Вместо этого переход к цифровым технологиям в образовании должен повлечь за собой инновационные подходы к преподаванию и обучению, модели и учебные программы, которые лучше всего подходят для онлайн-среды.
Возникающие передовые педагогические практики и идеи, которые могут последовать за этим толчком к цифровым технологиям, также могут быть интересны для всех библиотек, работающих над предложением виртуального программирования для менее фрормального обучения.

Многие библиотеки уже адаптировали свои учебные программы, от виртуальных разговорных классов до онлайн-рассказов и т. д. И может быть полезно следить за обсуждениями онлайн-обучения и образования в поисках новых идей или вдохновения.

Использование Интернета и ИКТ для поддержки эфрфективных ответных действий общества, восстановления и развития может быть достигнуто путем тесного сотрудничества и вклада многих заинтересованных сторон. Библиотеки имеют все возможности для реализации этого потенциала.

\section{5 НОЯБРЯ СОСТОЯЛОСЬ XXIV ОБЩЕЕ СОБРАНИЕ ЧЛЕНОВБИБЛИОТЕЧНОЙ АССАМБЛЕИ ЕВРАЗИИВ ФОРМАТЕ ВИДЕОКОНФЕРЕНЦИИ}

В собрании приняли участие руководители национальных и государственных библиотек Азербайджана, Армении, Беларуси, Казахстана, Кыргызстана, Молдовы, России, Таджикистанаи Узбекистана.

Одним из центральных вопросов повестки собрания стали выборы в правление БАЕ на 2020-2024 годы. По решению собрания, президентом БАЕ был избран генеральный директор Национальной библиотеки Беларуси Роман Степанович Мотульский, вице-президентами - генеральный директор Российской государственной библиотеки Вадим Валерьевич Дуда и директор Национальной библиотеки Узбекистана им А. Навои Умида Алимджановна Тешабаева.

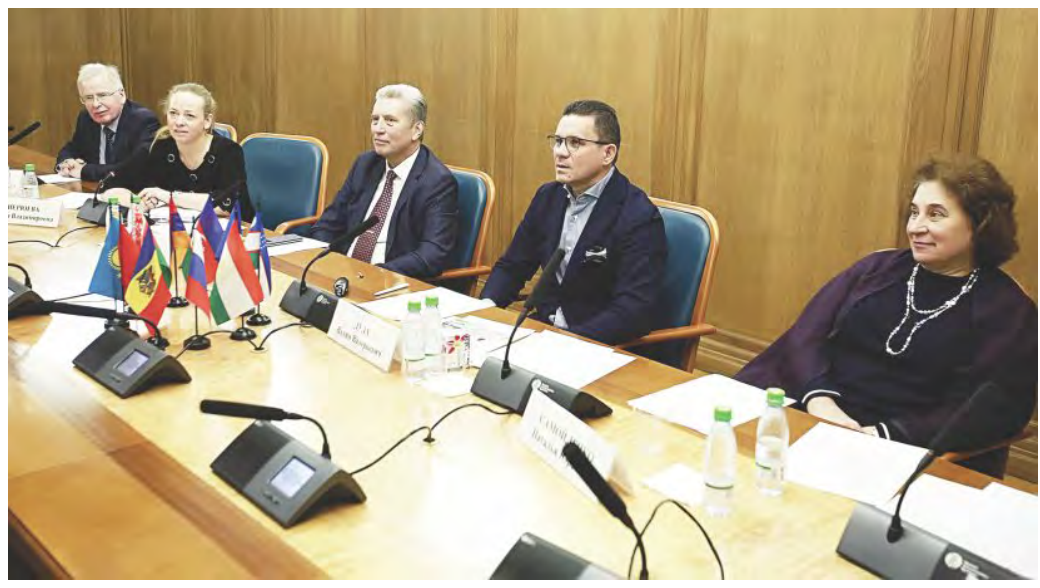

Одним из

центральных

вопросов повестки

собрания стали

выборы в правление

БАЕ на 2020-2024

годы. По решению

собрания,

президентом БАЕ

был избран

генеральный

директор

Национальной

библиотеки

Беларуси Роман

Степанович

Мотульский,

Вице-президентами

- генеральный

директор

Российской

государственной

библиотеки Вадим

Валерьевич Дуда и

директор

библиотеки

Узбекистана

им А. Навои Умида

Алимджановна

Тешабаева
Национальной 
Жемчужиной выставки стала

сессия

«Узбекистан

в творчестве

современных

писателей и

исследователей

литературы»,

в рамках которой

спикеры:

Дина Рубина

(Израиль) - Член

Союза писателей

Узбекской ССР

(1978), Элеонора

Шафранская (РФ)

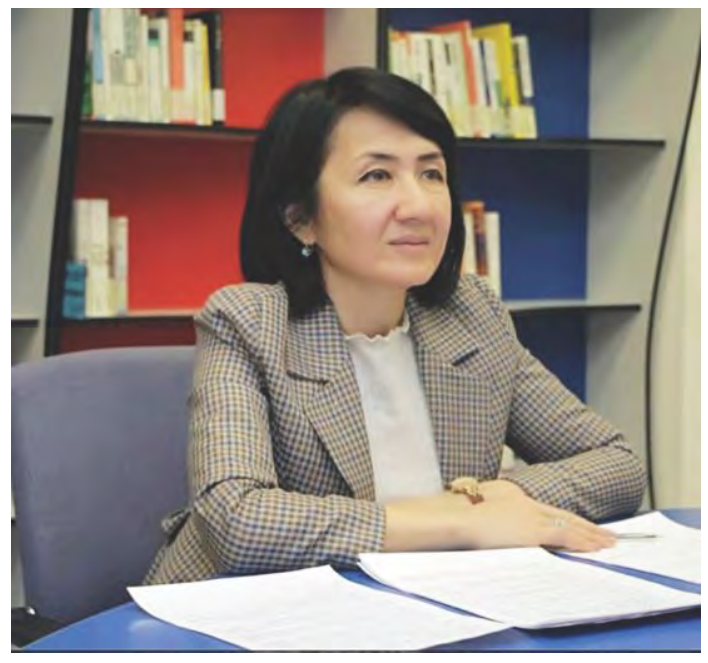

\section{॥ТАШКЕНТСКАЯ МЕЖДУНАРОДНАЯ КНИЖНАЯ ВЫСТАВКА «TASHKENT ВООК FEST» ВОНЛАЙН ФОРМАТЕ}

В соответствии с возложенными задачами Агентство инорормации и массовых коммуникаций при Администрации Президента Республики Узбекистан в 2019 году инициировало и провело в 2020 году II Ташкентскую Международную книжную выставку «Tashkent Book Fest» в онлайн фрормате.

Основная цель и задачи проведения выставки - пропаганда книги и чтения, поддержка и развитие литературного наследия странучастниц, фрормирование читательской культуры, изучение опыта мировой печатной индустрии и установление международных связей между книгоиздателями и книгораспространителями, инорормационно-библиотечными учреждениями и организациями, занимающими вопросами книг и чтения.

В выставке приняли участие 25 зарубежных участников, представляющих 11 стран: Бельгия, Великобритания, Израиль, Индия,
Казахстан, Киргизия, Российская Федерация, США, Турецкая Республика, Франция, Чехия.

Особо запоминающимися сессиями выставки стали:

Сессия «Переводы/Тонкости художественного перевода», в рамках которой спикеры Марк Эдвард Риз (США) - востоковед, переводчик узбекской литературы, в 2020 году награжден Государственной наградой Республики Узбекистан - Орденом «Дустлик»; Филип Нубель (Чехия) - главный редактор «Global Voices», редактор по литературе Центральной Азии в журнале «Asymptote Journal», переводчик; Камиль Тиллябаев (Узбекистан) - учитель международной школы Tashkent International school, переводчик, представили свои переводческие проекты и рассказали о тонкостях художественного перевода произведений. Также спикеры выразили большую заинтересованность в сотрудничестве по переводу узбекской классической и современной литературы на иностранные языки.

Жемчужиной выставки стала сессия «Узбекистан в творчестве современных писателей и исследователей литературы», в рамках которой спикеры: Дина Рубина (Израиль) Член Союза писателей Узбекской ССР (1978), Элеонора Шафранская (РФ ) - доктор срилологических наук, профрессор Московского гуманитарного педагогического университета; Галина Долгая - член Союза писателей Узбекистана, член Международной Гильдии Писателей; Борис Голендер - кандидат химических наук, научный сотрудник музея Сергея Есенина и модератор сессии Бабаев Борис - журналист, основатель платфрормы «Kultura.uz».

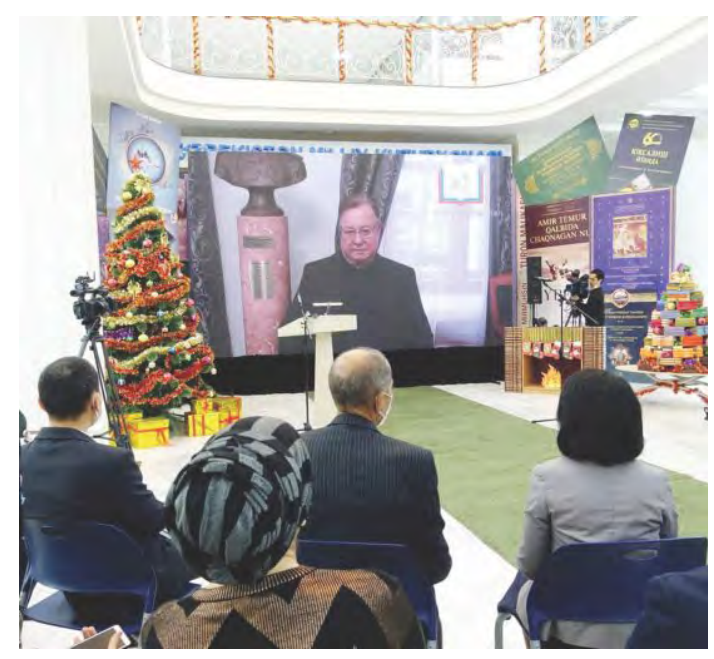




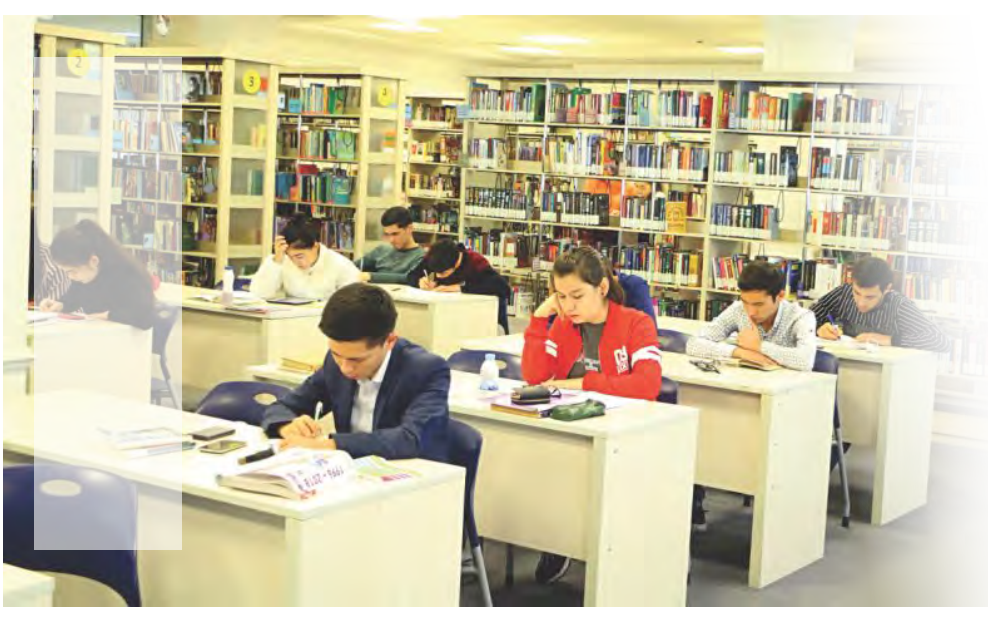

\section{«КУТУБХОНАЧИНИНГ КИТОБ ЎҚИМАСЛИГИ - МИЛЛАТ ЗАВОЛИ...»}

Социология франлари доктори, проорессор Абдусалом Умаров

билан сухбат

Абдусалом Умаров - мутахассислиги буйича журналист, мехнат фаолиятини бундан 55 йил муқаддам мактаб кутубхонаси мудирлигидан бошлаган. Дорилфунун тах,силидан кейин биринчи ўзбек энииклопедияси тахририятида, Низомий номидаги Педагогика институтида ишлаган. 1997 йили хозирги Алишер Навоий номидаги Ўзбекистон Миллий кутубхонаси директори этиб тайинланган. У филология фанлари номзоди, социология фанлари доктори, профессор сифатида кўплаб монография, дарслик, ўқув қўлланмалари хамда илмий ва публицистик мақолалар муаллифидир.

Абдусалом ака, социологолим ваузоқ йиллар кутубхонада фраолият олиб борган рахбар сифратида айтингчи, бугун халқимизнинг китобхонлик даражаси қай ахволда? Йиллар давомида илгарилаш кузатилдими ё таназзул?

Мураккаб савол. Китобхонлик даражасини ўлчаш учун олис ўтмишга назар ташлаш керак. Тарих бизга сабоқ берувчидир, мозий халқимизнинг нақадар китобхон бўлганлиги, китобнинг урни нақадар юқори тутилганлиги хақида дарак беради. Китоблар бир улов - от бахосида сотилган, демак қадри хам, қиймати хам баланд бўлган. Асрсуски, хозир хам шундай, деб мақтана олмаймиз, чунки китобхонлигимиз тушиб кетди. Сабабини, мен оилалардан, фрарзанд тарбия қилаётган отаоналардан кураман. Оилада китобга мехр, хурмат, унга азиз яратиқ сисратида қаралмас экан, ўша хонадондан китобхонлар чиқишини кутиш хато бўлади. Чунки ота-она, бобо-буви нимани лазиз билса, нимага кўпроқ эътибор қаратса, мурғак гўдак хам шунга эътибор қаратади, китобга кўринмас ип билан боғлиқлик хосил бўлади. У китоб билан ўсиб боради. Кейин мактаб, кутубхона тарбияси бошланади. Китобхонлик хам тизимлиликни, тартибни талаб қилади. Иш мунтазам олиб бормаса, китобхон бўла олмайди. Китобхонликка кириш хам қийин, чиқиш хам. Китобнинг таровати сира бизни тинч қўймайди.

Лекин бугун китобхонлар камайди, бунга жойларда кутубхоналарга бўлган катта эхтиёжнинг вақтида тўлдирилмагани сабаб бўлди. Китобларнинг адади ва уларга берилаёт- ган тақризлар, реклама ва бошқа омиллар бозор хукмига буйсунди. Бундан ташқари, 2006 йилда бир қарор чиқдики, яъни жойлардаги хаммабоб кутубхоналар таълим муассасалари кутубхоналарига бўлиб берилди. Натижада, вилоят марказларидаги ўн турртта илмий универсал кутубхоналардан ташқари барча кутубхоналар юридик шахс мақомидан махрум бўлди. Кутубхоналарни ахборот-ресурс марказларига айлантирамиз, замонавий технологияларни олиб кирамиз ва шу орқали ривожлантирамиз, деган катта мақсад бор эди, аммо амалда ундай бўлмади. Қишлоқ кутубхоналари ўрнини хеч нима боса олмади, таълим муассасаларига эса ахолини киритишмади. Натижада жойларда китоб учун катта эхтиёж пайдо бўлди ва биласизки, эхти-

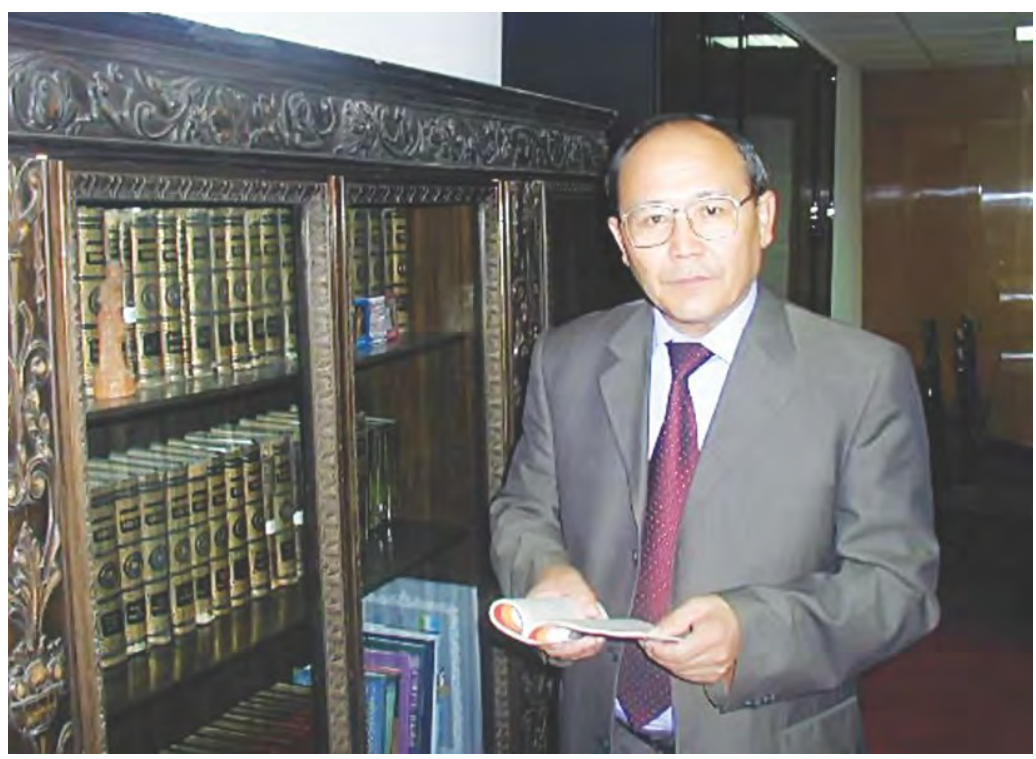




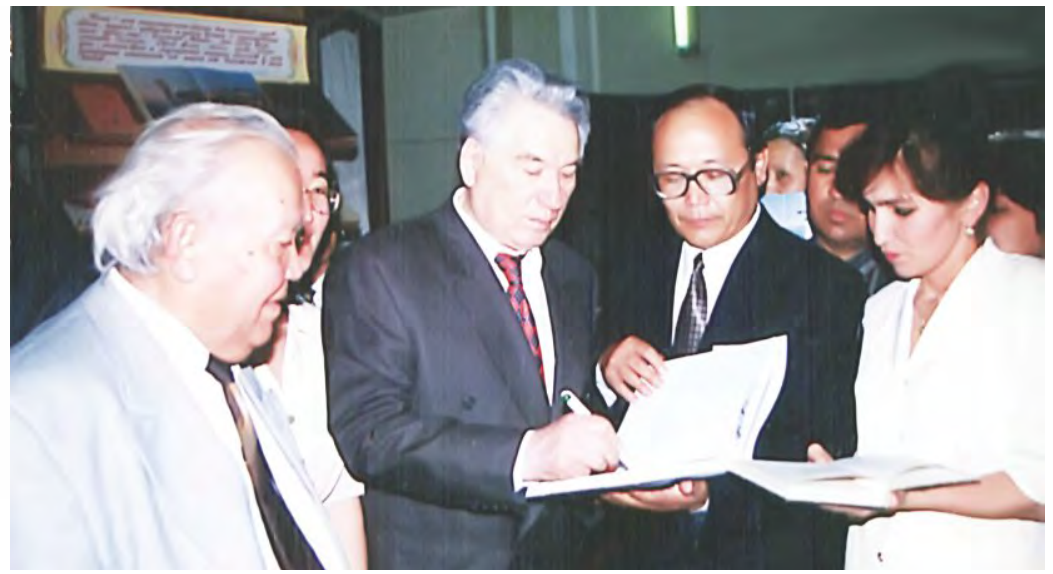

ёж вақтида қондирилмагач, йў бўлади, бунинг жабрини хамон тортиб ётибмиз. Кўрдингизми, биргина пухта у̌йланмай қилинган

Азалдан замон

янгиликларини

тез илғайман ва

мослашаман.

Манбаларнинг

электрон шаклга

ўтиши замон

талаби. Бир

кутубхона кичкина

компьютер ёки

планшетларда

сақланишидан

қувонмай

бўладими?!

Кутубхоначилар ўқимаслиги катта йўқотиш, бундан

миллатимиз

маънавияти ва маданиятига зиён

етади. Улар

бугунги кун

талабига жавоб

бериш керак.

Кутубхоначининг

савияси -

жамиятнинг

маданий савияси

мезонидир харакат қандай оқибатларга олиб келиши, тузатиб бўлмас яраларни хосил қилиши мумкин. Ўз қўлимиз билан минглаб китобхонларни бой бердик.

Китобга мехр ўз-ўзидан пайдо бўлмайди, мурғак болага китоб сирларини очиши учун ота-она, устозу мураббийлар тер тўкиши, захмат чекишлари керак. Бугун ўзбек оилаларида китобўқиш маданияти қай даражада?

Хавас қиларли эмас. Биласиз, ўзбек оилаларида болалар бобоси, момоси қўлида тарбия топади, лекин уларнинг қўлида хам камдан-кам китоб кўрамиз. Уларни доим китоблар билан таъминлаб туриш масаласи хам вужудга келган. Боя таъкидлаганимиздек, кутубхоналарнинг ёпилгани, катта салбий оқибатларни келтириб чиқарди ва бунинг уурни хали-хамон тўлмаса керак?!

Мен Самарқанд вилоятининг Қўшработ вилоятида туғилганман. Бизнинг болалик кенг далаларда ўтди, электр чироқлари орзу эди. Лекин китоб ўқишимизга, билим олишимизга бу сира тўсқинлик қилмаган. Бизга энг мароқ берадиган нарса китоб эди, ундан бўлак хеч нима, хатто радио хам хамма уйда йўқ бўлиб, телевидение эса ёруғ орзу эди. Эсимда бор, бешинчи синфда отам суратли «Ўзбек халқ эртаклари» китобини олиб келиб берган. Ўшандан бери китобларга асирман. Мени китоб ўзим бормаган жойларга тасаввур орқали боришга ундаган, ўзим хали хис қилмаган туйғулар таъмини туйишга уургатган. Мен хозир хайратларим ўлмаслиги учун китоб ўқийман.

Сиз, босма китоблар ўқиган китобхон, асосан, кутубхоналарда фраолият юритган одам сифратида айтингчи, Сизни электрон китоблар, электрон кутубхоналар ва онлайн дарслар хавотирга соладими ё хурсанд қиладими?
Хавотирга солмайди, қайтанга хурсанд қилади. Азалдан замон янгиликларини тез илғайман ва мослашаман. Манбаларнинг электрон шаклга ўтиши замон талаби. Бир кутубхона кичкина компьютер ёки планшетларда сақланишидан қувонмай бўладими?!

Хозир мени электрон китобларга мухаббатим ошиб бормоқда. Чунки уни истаганча кўзимга яқинлаштириб кўришим мумкин, ёш улғайгач биласизку, кўз хира тортади, бу айнан мен боп бўляпти. Бундан ташқари, мақола ёзиш, уни тахрирлашда хам кўпгина қулайликлар бор. Бу катта имконият.

Айни пайтда Навоий вилояти, Навбахор тумани ахборот-кутубхона маркази кутубхоначиларининг телеграм каналига аъзо бўлганман. Улар хар куни ўттиз-қирқта китобни электрон шаклда сахифрага улашади. Уларнинг чекка туман бўлса-да, замонга мослашгани қувонтиради. Мен хар куни уларнинг каналига кириб, кўплаб нарсаларни оламан. Шунинг учун шу сухбат орқали уларга ташаккур билдирмоқчиман.

Китобларнинг сотиб олингани эмас, ўқилгани хазина. Лекин кўпгина кутубхоначиларнинг китоб ўқимаслиги ва китобга мухаббати йўқлигин пайқаб ранжийсан киши. Китоб ўқиган ва унга бефрарқ бўлган кутубхоначи ўртасидаги тафровутни нималарда кўрасиз?

Билмасам, китоб ўқимайдиган кутубхоначиларни укол қила олмайдиган хамшираларга ўхшатишган. Китоб ўқимайдиган кутубхоначи миллат келажагининг заволидир. Мана қаранг, чаманзор боққа борсангу гулни хидламай ўтсанг, китоблар ичра умринг ўтсаю, битта китоб ўқимасанг, бу фожиа даражасида. Кутубхоначилар ўқимаслиги катта йўқотиш, бундан миллатимиз маънавияти ва маданиятига зиён етади. Улар бугунги кун талабига жавоб бериш керак. Кутубхоначининг савияси - жамиятнинг маданий савияси мезонидир.

Мана бир неча йиллардан бери «Kutubxona.Uz» журналининг бош мухарририсиз, қолаверса, шу соха вакилларини етиштириб берадиган таълим даргохининг профессорисиз, айтингчи, бўлажак кутубхоначиларнинг савияси қандай? Улар кўпроқ нималарга эътибор қаратиши керак?

Бугунги кун кутубхоначилари икки йўналишда тайёрланаяпти. Биринчиси техник йўналишда, иккинчиси маданиятнинг бир йўналиши сифатида. Маълум муддат фақат ахборот улашувчи, техник кутубхоначилар тайёрлашга урғу берилди, аммо бу у̌зини оқламади. Анаънавий таълимга қайтилди, кутубхоначи- 
лик сохасини аввало маданий асосга қўйилмаса, кўп нарса кемтик бўлиши маълум бўлди ва хозирда Ўзбекистон давлат санъат ва маданият институтида кутубхоначилар тайёрланмоқда. Албатта, улардан умидимиз катта. Бугунги кун кутубхоначиси дунёнинг шу сохада эришган барча ютуқларидан бохабар бўлиши, замон ва ёшлар талабини тез илғаши, уларга йўл кўрсатиш учун ўзи заковатли шахс бўлиши керак. Шунинг учун хам жахонда кутубхоначи касбига юксак хурмат ва эътибор билан қарашади. Кутубхоначи - педагок, унинг тавсиялари кўп нарсани ўзгартириши мумкин. Сўраган китобни жавондан олиб бериш - бу хали кутубхоначи дегани эмас. Лекин кўпчилик кутубхоначи ишини шундай жўн тушунади, бу эса катта хато.

«Kutubxona.Uz» журнали бу сохадаги, таъбир жоиз бўлса, делитантликка бархам бериш учун илғор тажрибаларни тарғиб қилиш, истеъдодли кутубхоначиларни элга танитиш, уларга кенг минбар бўлиш вазифасини ўтаб келмоқда..

Миллатнинг юксалиши, давлатнинг тараққий этишида илм-франнинг хизматларини тугғри англамайдиган, ундан тез ва реал натижа кутадиган, акси бўлса, илмдан воз кечадиган рахбарлар кўп. Сизнинг-ча миллат тараққиётида илмнингуурни қандай?

Илмсиз бирон соха ўсмайди, янгиланмайди. Бугун буни англаб, сергак тортдик. Фанлар академиясининг фраолияти йўқолиб, илмий тадқиқотларнинг миллатга натижаси умуман сезилмай қолди. Биз кўп нарсани йўқотдик. Кўп ёш олимлар мамлакатни тарк этиб кетишди. Хадисда айтилганидек, бизни қутқарадиган куч хам, нажот хам - илм, бошқа нарса эмас, Хозир, шукрки, илм-маърифратга эътибор катта, миллат тақдири ва келажагимизни ўнглаш илм билан амалга ошиши хаммага маълум бўлиб бормоқда. Дунёдаги барча жабхалар бизга илмий савиямиз даражасида очилади. Дунёни уурганишдан қочмайлик. Болаларимизни дипломли қилиш эмас, чин маънода билимли қилиш учун курашмоғимиз керак, урғуни шунга беришимиз зарур. Миллатнинг эртаси таълимда.

Техник ходим хам ижодкор бўлиши керак. Хамма одамда истеъдод бор, буларни тарбиялаш миллий ғоя тарзида қўйилди, кутубхоначилар бунга бефарқ қарамаслиги зарур. Олимлар ва ёш тадқиқотчилар учун кутубхоналарда барча имкониятлар мухайё бўлиши лозим. Кутубхона олимларга биринчи даражадаги ёрдамчи бўлиши керак.

Кутубхоначи китобхонга китобларни сара-

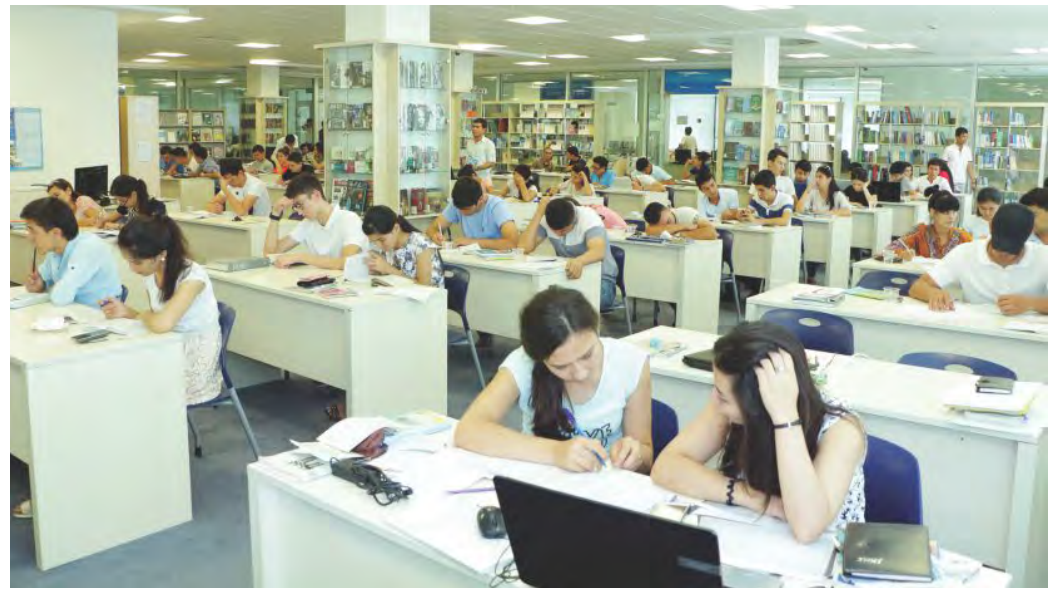

лаб бериши керак, деймизу, лекин бугун адабиётимизда саралаш тизими ишлаяптими ўзи, деб ўйлаб қоламиз. Адабиётимизда танқид йўқолиб кетди. Айтайлик, юртимиздаги машхур «Адабиёт ва санъат» газетасида биронта тақриз чиқмайди, бу нима дегани? Авваллари бирор сони бахссиз бўлмасди. Шунинг учун одамлар бу газеталардан узоқлашиб кетаяпти, натижада, ёшлар келажаги учун мухим китоблар, бадиий асарлар сараланмаяпти, бу катта йўқотиш... Бу, афссус билан қайд этиш керакки, миллатнинг китобхонлик диди тарбияланмаётганидан ва мутолаа маданияти даражаси пастлашиб кетаётганидан дарак беради.

Хаётингиздаги Миллий кутубхонанинг ўрни ва бу даргох китобхонлари-ю, ходимларига талаб-у истакларингиз.

Бу даргох жуда улуғ маскан. Бу ерга келганимда дастлаб жамоага бирдан киришиб кета олмаганман. Ўшанда кутубхонада директор ўринбосари бўлиб ишлаётган рахматли Хамида Умарбекова бир гапни айтганди: «Абдусалом Одилович, кутубхонанинг тупроғи оғир бўлади, одам бу ерга келадию, кетиши қийин бўлади». Ўша пайтда «Эй, кўнгил учун айтди-қўйди-да!» дегандим, лекин йиллар ўтиб билдим, чиндан бу даргохнинг тупроғи «оғир» экан, машаққати қадрли, кета олмай қолдим. Ўн беш йил рахбарлик қилдим. Бўшаб кетганимдан сўнг хам бу ердан сира узоқлашмадим, нимадир мени тортиб турди, барига сабаб китоблар ва бу даргохнинг одамлари бўлса керак. Яқинда ўз кутубхонамдан иккита нодир китобни Миллий кутубхона фондига тортиқ қилдим, бу ерда уларни ўқишади, тадқиқ қилишади, ўрганишади. Мен хар сафрар бу ерга келсам, ёшлар гавжум, уларни кўриб севиниб кетаман. Мен хам улардек бир китоб, бир жой учун навбатда тургим келади. Сухбатдош Жавлон Жовлиев
Дунёдаги барча жабхалар бизга илмий савиямиз даражасида очилади. Дунёни ўрганишдан қочмайлик.

Болаларимизни дипломли қилиш эмас, чин маънода билимли қилиш учун курашмоғимиз керак, урғуни шунга беришимиз зарур. Миллатнинг эртаси таълимда

\section{Мен хар сафрар} Миллий кутубхонага келсам, ёшлар гавжум, уларни кўриб севиниб кетаман.

Мен хам улардек бир китоб, бир жой учун навбатда тургим келади 


\section{ВАРИАТИВНОСТЬ ПОИСКА}

ИНФОРМАЦИИ И МЕЖБИБЛИОТЕЧНЫЕ УСЛУГИ

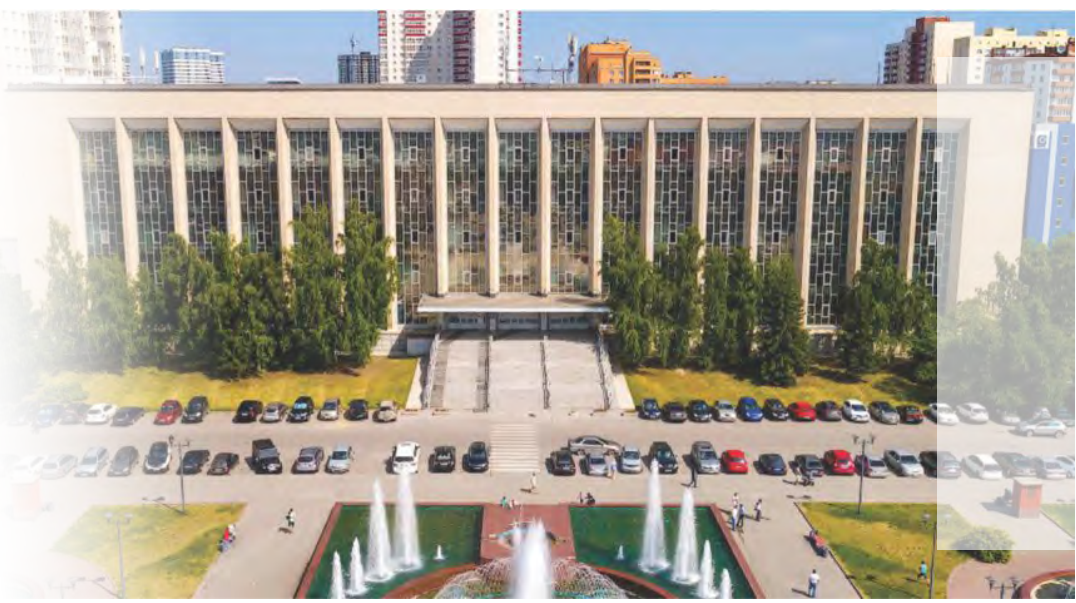

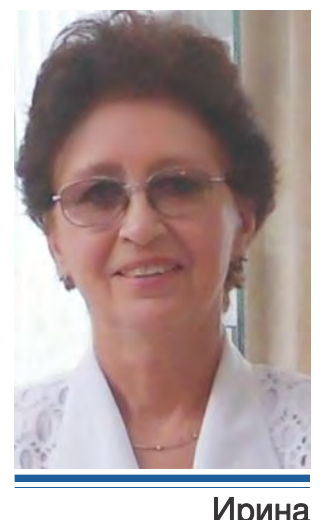

Красильникова,

старший научный сотрудник научнотехнологического отдела,

Государственная публичная научно-техническая библиотека СОРАН, Новосибирск, Россия

А.С. Пушкина, krasilnikova@spsl.nsc.ru

Актуальность проблемы связана с нарастанием количества электронных ресурсов во многих информационно-библиотечных учреждениях, необходимостью поиска информации из любых источников, в т. ч. внешних, предоставление документов из группы фрондов (корпораций), наличием электронных каталогов и систем поиска. Поиск инорормации по каталогам и другим поисковым системам всегда предшествовал выполнению заказов в межбиблиотечном обслуживании. Заимствования и использование документов из разных коллекций (оказание межбиблиотечных услуг) возможно только при наличии актуальных метаданных современных инорормационно-поисковых систем (ИПС). Цель статьи - обобщить результаты изучения нескольких разновидностей поисковых систем. При этом обращалось внимание на новые научные публикации по исследуемой теме. Представлен анализ отечественных и зарубежных материалов о вариантах поиска информации, которая весьма необходима пользователям, в т. ч. удалённым при оказании межбиблиотечных услуг.

Ключевые слова: информационно-поисковая система, интеллектуальные системы, межбиблиотечные услуги, межбиблиотечный абонемент и доставка документов, поиск инорормации, сервисы discovery, электронные каталоги.

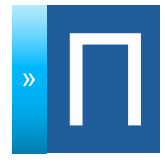
оиск инорормации является одним из необходимыхвидов деятельности человека. Современные научные библиотеки в мире сетевого взаимодействия стремятся создать качественный контент, чтобы помогать локальным и удалённым пользователям находить и получать доступ к документам. Как отмечают исследователи, библиотеки всегда ориентировались на проведение информационной навигации (процесса вождения пользователя по логически связанным данным) в различных источниках. Предоставление содержательного и полезного наполнения инорормационных ресурсов для аудитории пользователей с помощью инструментов поиска является одной из ценностных задач научных библиотек в эпоху избытка и разнообразия инорормации.

Из общего контингента пользователей выделяются те, которые обращаются к системе межбиблиотечного абонемента и доставки документов (МБА и ДД) на локальном национальном и международном уровне. Службы данной системы тесно связаны с поиском библиографических описаний документов в электронных каталогах (ЭК) и зависят от выстраивания корпоративных технологий с разными инорормационно-библиотечными учреждениями по удовлетворению заказов. Как отражает источник [1], в мире существуют свыше 20 библиотек разного статуса, фронды которых превышают 14 млн экз. и доступны в сетевом режиме. В их число входят 6 российских центров: 2 Национальные библиотеки (Российская государственная библиотека РГБ; Российская национальная библиотека РНБ); 4 библиотеки Российской академии наук (РАН) (Библиотека Академии наук - БАН; Библиотека по естественным наукам - БЕН; Государственная публичная научно-техническая библиотека Сибирского отделения ГПНТБ СО; Фундаментальная библиотека Института научной инорормации общественных наук). Наряду с обслуживанием пользователей библиотеки проводят изучения вопросов о поисковых возможностях ЭК и баз данных (БД), включении модулей заказов МБА и ДД и личных кабинетов в автоматизированные инорормационно-библиотечные 
системы (АБИС), выявлении причин отказов. Обобщённые результаты дают богатый материал для актуализации, корректировки функций, обновления и совершенствования инфрормационно-поисковых систем. Действующий ГОСТ 7.73-96 приводит определение: Информационно-поисковая система (ИПС) совокупность справочно-информационного фонда и технических средств инфрормационного поиска в нём. Помимо этого, имеется термин: Автоматизированная информационно-поисковая система, реализованная на базе электронно-вычислительной техники [2].

ИПС необходимы любому пользователю научных библиотек, особенно тем, кто связан с прикладной и фундаментальной наукой, которая по своей природе интернациональна. Пользователи любых стран, занимающиеся интеллектуальной деятельностью, всегда заинтересованы в оперативном подборе сведений для решения стоящих задач. Одни из них ожидают, что обнаружение инфрормации и доставка будут тесно связаны, а другие отдают приоритет немедленному полнотекстовому доступу. В любом случае важными этапами выполнения заказов в службах МБА и ДД многих отечественных и зарубежных информационно-библиотечных учреждений являются процессы по разысканию и извлечению данныхо документах.

Рассмотрение систем поиска и

их возможностей

Проведённый в ГПНТБ СО РАН (2020 г.) выборочный анализ публикаций и матери- алов с сайтов крупных библиотек, консорциумов, объединённых информационных систем показал, что существует большое разнообразие поисковых ресурсов, циркулирующих в веб-среде. Результаты анализа в общем виде сгруппированы в табл. 1. В ней представлены глобальные, национальные, тематические ИПС универсального, отраслевого и специализированного контента, отражающие все виды документов любых форматов.

Так, пользователи библиотек имеют богатый арсенал отечественных и зарубежных ИПС, которые дают возможности доступа к ресурсам в любое время, из любой точки мира, с разных электронных устройств. Однако следует отметить, что системы поиска созданы не по кальке, одна отличается от другой, имеют специфические особенности, которые зависят от видов ресурсов, применяемых инструментов поиска, задач обращения и накопленного опыта пользователя, условий доступа и др. обстоятельств.

Анализ организации и использования электронных каталогов в ГПНТБ СО РАН. Среди систем поиска наиболее распространёнными в современных библиотеках разных уровней являются ЭК, что соответствует названию онлайн каталог открытого доступа (Online Public Access Catalog - OPAC). Изучение использования ЭК постоянно находится в поле зрения сотрудников ГПНТБ СО РАН, например, в публикациях Г. А. Скарук [3; 4; 5]. В одной из работ [5] оценена частота применения в поиске инорормационно-поисковых

\section{Среди систем} поиска наиболее распространённым и в современных библиотеках разных уровней являются ЭК, что соответствует названию онлайн каталог открытого доступа (Online Public Access Catalog - OPAC)

\begin{tabular}{|c|c|c|c|c|c|c|}
\hline № & $\begin{array}{l}\text { Названия центров, } \\
\text { систем, ИПС }\end{array}$ & K-BO & $\begin{array}{c}\text { Виды систем } \\
\text { и сервисов }\end{array}$ & Тематика & $\begin{array}{c}\text { Локация / } \\
\text { веб-адреса }\end{array}$ & $\begin{array}{l}\text { Платно / } \\
\text { бесплатно }\end{array}$ \\
\hline 1 & $\begin{array}{l}\text { Поисковые системы и } \\
\text { сервисы инфрормаци- } \\
\text { онно-библиотечных } \\
\text { центров России }\end{array}$ & 10 & $\begin{array}{l}\text { Более } 65 \text { названий } \\
\text { каталогов и БД }\end{array}$ & $\begin{array}{l}\text { Универсальная } \\
\text { и по многим } \\
\text { отраслям знаний }\end{array}$ & $\begin{array}{l}\text { Указаны по } \\
\text { конкретным } \\
\text { названиям }\end{array}$ & + частично / + \\
\hline 2 & $\begin{array}{l}\text { ИПС и сервисы в } \\
\text { зарубежных инорор- } \\
\text { мационно-библиотеч- } \\
\text { ных центрах }\end{array}$ & 5 & $\begin{array}{l}10 \text { сервисных интегрированных } \\
\text { систем поиска и } 2 \text { службы } \\
\text { совместного использования } \\
\text { ресурсов (МБА и ДД): British } \\
\text { Library Document Supply } \\
\text { Service - BLDSS; Online } \\
\text { Computer Library Center - OCLC }\end{array}$ & $\begin{array}{l}\text { Универсальная } \\
\text { и по многим } \\
\text { отраслям знаний }\end{array}$ & $\begin{array}{l}\text { Указаны по } \\
\text { конкретным } \\
\text { названиям }\end{array}$ & + частично / + \\
\hline 3 & $\begin{array}{l}\text { Крупнейшие } \\
\text { международные ИПС }\end{array}$ & & $\begin{array}{l}\text { Библиограсрические, рефе- } \\
\text { ративные, тематические, } \\
\text { полнотекстовые БД и } \\
\text { электронные библиотеки (ЭБ) }\end{array}$ & $\begin{array}{l}\text { Естественные, } \\
\text { технические, } \\
\text { математические, } \\
\text { гумманитарные и } \\
\text { др.науки }\end{array}$ & $\begin{array}{l}\text { Указаны по } \\
\text { конкретным } \\
\text { названиям }\end{array}$ & + частично / + \\
\hline
\end{tabular}

Таблица 1. Основные результаты анализа российских и зарубежных ИПС 
языков (ИПЯ). Первое место по активности использования занимал ИПЯ ключевых слов, второе - предметизационный (по указанной теме). Определены типовые поисковые стратегии, способы фрормулировок и корректировки поисковых предписаний. Выявлены проблемы поиска, возникающие у пользователей (применение простых поисковых стратегий, многократная формулировка поисковых предписаний, просмотр небольшого количества страниц с результатами поиска).

Предметный поиск. ОРАС в большинстве стран располагает эфрфективным механизмом поиска, в основе которого лежит «предметный вход», иначе говоря - один из видов вербального индексирования. В этом случае следует особо отметить роль схем классификации, правил каталогизации, компьютерочитаемых библиографических фрорматов, тезаурусов и т. п. Точность индексации влияет на доступ к инорормационным источникам. В противном случае поиск может быть неудовлетворительным. Предметный поиск, предпринятый в шведских поисковых службах оказался далек от оптимального, хотя фронды были индексированы по правилам, но индексы использовались не эфффективно [6].

Анализ факторов и моделей поведения пользователей изучают многие исследователи в разных странах, среди них авторы из России: Ю. М. Брумштейн, Е. Ю. Васьковский, Т. Х. Куаншкалиев [7]. Они рассмотрели

инженерами и

технологами,

работающими

в Университете

Пенджаба

(Индия), отражено

в статье авторов:

Arshad Alia,

Ameen Kanwal
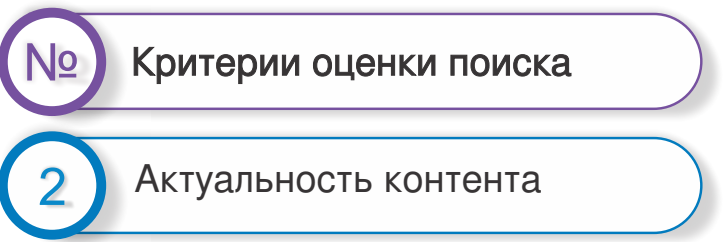

\section{3 Полнота}

\section{4 Точность}

5. Специфичность

\section{6 Оперативность}

Таблича 2 .

Оиенки

эффективности функционирования типичные цели поиска информации в сети разными категориями пользователей: чтение, скачивание, анализ найденной инфрормации. Также определены причины, влияющие на тактику поведения пользователей при поиске: уровень мотивации к получению адекватных результатов; время доступа; имеющейся начальный объём инфрормации; оценки полноты и качества результатов; уровень информационно-телекоммуникационной компетентности, в т. ч. в отношении ИПС; скорость доступа к интернет-ресурсам; технические характеристики устройств, с которых осуществляется доступ; уровень интеллектуальности систем; влияние языкового барьера на тактику поиска. Главным источником инорормации для исследователей всегда являлись научные статьи.

Поиск электронных статей из научных журналов. Как пользователи находят статьи в электронной среде? Этому вопросу посвящено исследование Н. Н. Литвиновой [8]. Выявлены наиболее часто используемые: рефреративно-библиограсические БД, специализированные научные поисковые сервисы, а также сайты библиотек, издателей, журналов и социальные сети. Дан анализ возможностей библиотек в настройке сервисов для лёгкого перехода пользователей от кратких описаний статей (библиографических записей) к их полным текстам. Отмечен приоритет стандартизованного обмена данными в России между контент-провайдерами, службами поиска и библиотеками. Подчёркнута необходимость их интеграции в целях большей видимости и цитируемости отечественных авторов. Описаны нормативные документы, утверждённые Национальной организацией инорормационных стандартов США (National Information Standards Organization - NISO), регламентирующие обмен данными между издателями и агрегаторами, разработчиками сервисов discovery и библиотеками для обеспечения унифрицированного режима обмена срорматов.

Изучение различных источников о поиске электронных журналов инженерами и технологами, работающими в Университете Пенджаба (Индия), отражено в статье авторов: Arshad Alia, Ameen Kanwal [9]. Обобщены данные анкетного опроса, в котором уровень ответов достиг $61 \%$. Наиболее часто респонденты искали: электронные журналы и книги, отчёты дискуссий и проектов. Доступ к статьям электронных журналов проводили через общедоступную поисковую систему Google 
Scholar и веб-сайты журналов Открытого доступа - ОД (англ. Open Access - OA). Большинство респондентов искали материал, чтобы быть в курсе проводимых в мире исследований. Одним из научных достижений учёных считается издание монографиий.

Доступность сведений о монографиях открытого доступа. Можно ли обнаружить монографрии ОД в библиотечных каталогах? На этот вопрос частично может пролить свет статья A.McCollough [10]. Представлены итоги работы о состоянии ОД относительно монограсрий в библиотеках колледжей и университетов США и Канады. Эмпирическую основу составили публикации электронных книг по культуре издательства Michigan Publishing, чтобы собрать оценки мнений пользователей, сотрудников библиотек и издателей. Фактически оказалось, что академические публикации в целом и особенно монограсрии ОД трудно обнаружить в библиотечных каталогах. Лишь небольшой процент каталогов библиотек учебных заведений постоянно обеспечивает поиск и доступ к подобным изданиям. Проводя поиски, пользователи ожидают от ИПС высокое качество контента, подсказок в выборе стратегии, помощи в устранении ошибок, на что ориентированы рекомендательные системы.

Рекомендательные системы представляют собой программный комплекс, который определяет интересы, предпочтения пользователя и формирует предложения по поиску в соответствии с ними. Такие системы действуют в любой отрасли, меняя способы взаимодействия со своими пользователями. Кроме предоставления статической инсрормации системы подстраиваются под запросы пользователя, увеличивая степень интерактивности для расширения возможностей поиска[11].

Для преодоления трудностей поиска и получения большего объёма инфрормации, в Университете Порту (University of Porto), Португалия разработали рекомендательную систему, которая предоставляет альтернативные запросы, сочетающие португальский или английский язык с непрофессиональной или медико-научной терминологией [12]. Некорректность работы системы поиска инсрормации является принципиальным фрактом в области здравоохранения, поскольку может навредить здоровью пользователя (пациента). Оценка системы показала, что знание языка и терминологии влияет на точность предложений по медицинским запросам. Простое
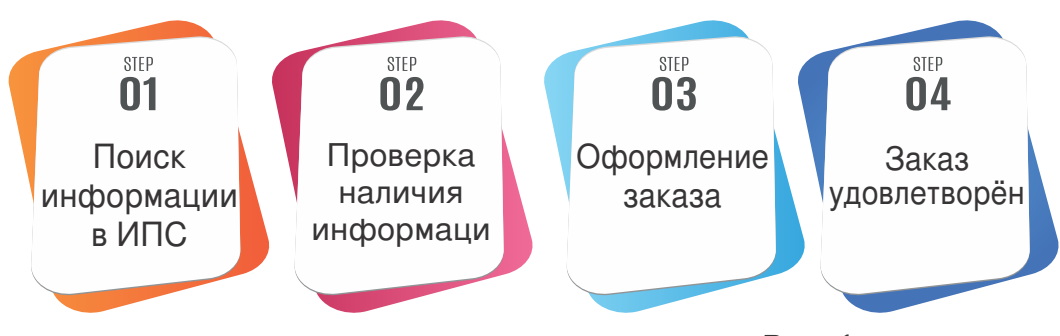

предоставление подсказок способствует уменьшению количества неправильных ответов. Анализ по типам предложений и характеристикам пользователей показал, что эффрект владения английским языком более значителен, чем уровень медицинской грамотности. С учётом этих характеристик возможна настройка фрункций на персональные запросы пользователей.

Связанные открытые данные для обогащения поиска. Различные рекомендательные стратегии, облегчающие поиск корпоративных библиографрических, пользовательских и цитированных данных, позволили выйти ITспециалистам с предложениями по обращению к связанным открытым данным (СОД или англ. Linked Open Data - LOD). Массив СОД может помочь библиотекам в решении вопросов каталогизации и общедоступности средств поиска инорормации [13; 14].

В РГБ опубликована Классисрикационная система (https://lod.rsl.ru) для поиска в электронном каталоге через Глобальную сеть в рамках проекта по поддержке контента и предоставлению интероперабельности (англ. Interoperability - совместимость) с другими ресурсами. Предполагается сотрудничество с другими российскими библиотеками по созданию общего семантического пространства связанных открытых словарей [15].

Авторы L. Wenige, J. Ruhland из Германии [16] рассмотрели возможности использования СОД для автоматизированных рекомендаций по поиску в цифрровых библиотеках. В рекомендациях подчёркнута оптимизация общего поиска, предложены недорогие средства обнаружения ресурсов, особенно, когда пользователи не знакомы с доменом или затрудняются с фрормулировкой запроса. Определены преимущества СОД, позволяющие объединять поисковые запросы и рекомендованные методы для поиска научной информации.

Возможности интеграции данных из различных БД, необходимость обращения $\mathrm{k}$ внешним источникам, заимствование документов из группы фрондов и корпораций привели к развитию каталогов нового поколения
Puc. 1.

Прямая передача и получение заказа на электронную копию

\section{Эмпирическую}

основу составили публикации

электронных книг

по культуре

издательства

Michigan

Publishing, чтобы

собрать оценки

мнений

пользователей, сотрудников

библиотек и

издателей

\section{Для преодоления}

трудностей поиска и получения большего объёма информации, в Университете Порту (University

of Porto),

Португалия

разработали

рекомендательную

систему, которая

предоставляет

альтернативные

запросы, сочетающие португальский или

английский язык

с непрофрессиональной или медико-

научной

терминологией 
мантический и контекстный поиск и др.).

Исследования в области развития

ИС направлены

на достижение

такого понимания

механизмов

интеллекта,

при котором можно

будет составлять

компьютерные

программы

с человеческим или

более высоким

уровнем интеллекта

Интегрированный поиск инорормации

через один

интерфейс

во множестве

разнородных

источников,

объединенных

в сеть, позволяет

использовать

децентрализован-

ные сервисы,

предоставляющие

гибкость и свободу

действий для

заказа по

межбиблиотечному

обслуживанию и систем класса Web Scale Discovery [17].

Системы Web Scale Discovery (обнаружения веб-масштаба). Приоритетным этих систем считается огромный массив высококачественного полнотекстового контента, объединённого в рамках единого поискового индекса [18], что обеспечивает локальный и распределенный доступ ко всем ресурсам информационно-библиотечных центров в целях полного открытия коллекций, включая удалённые полнотекстовые лицензионные БД. Пользователи могут искать контент в фризических и электронных коллекциях и других ресурсах из одного поискового окна. Результаты поиска отображаются в ранжированном списке релевантности со ссылками, аналогично с Интернетом [19].

За последние годы в библиотеках Университета Хьюстена (University of Houston Libraries - UHL), США внедряли несколько discovery разработок, улучшающих доступ к электронным ресурсам: LibraryFind, Encore, Summon и Primo. В одном из кампусов выбрали систему Primo, обеспечивающую нейтральность контента, совместимость с огромным числом других систем, создание учётных записей конечных пользователей и доставку документов. В ходе поисков были определены стержневые критерии оценки систем поиска и накоплен опыт в их обновлении [20]. Системы Web Scale Discovery позволяют зарубежным академическим библиотекам удовлетворять запросы преподавателей, исследователей, студентов, в т. ч. путём децентрализованного заказа по МБА и ДД.

Резервы ИПС и эффективность

межбиблиотечных услуг

В исследованиях отмечено, что системы Web Scale Discovery обладают потенциалом, который радикально меняет характер взаимодействия пользователей с коллекциями библиотек в обширном инфрормационном пространстве [18; 21]. С каждым днём поисковые возможности ИПС становятся всё более точными, разрабатываются и внедряются интеллектуальные системы - мощные средства поиска [22; 23]. Они обеспечивают быстрый и эффрективный поиск многообразных материалов, как традиционным способом, так и на основе интеграции систем, использующих аналитические инструменты (анализ текста, семантический и контекстный поиск и др.). Исследования в области развития ИС направлены на достижение такого понимания механизмов интеллекта, при котором можно будет составлять компьютерные программы с человеческим или более высоким уровнем интеллекта. Общий подход состоит в разработке методов решения задач, для которых отсутствуют фрормальные алгоритмы [24].

Благодаря инновационным технологиям расширяются технические возможности, совершенствуется технологическая база поисковых систем, обновляется интерфейс, ${ }^{1}$ который становится более понятным и удобным для пользователя, чтобы взаимодействовать с операционной системой компьютера, мобильного устройства или других видов техники.

В публикациях, отразивших лучшие варианты поиска для пользователей и удобный доступ к электронным ресурсам, определены критерии оценки систем поиска. Как прави ло, ИПС оценивают с разных точек зрения (табл. 2).

Если следовать разработанным международным стандартам, рационализации передачи поисковых запросов между системами нового поколения с инструментами обмена инсрормацией и ресурсами, то межбиблиотечные услуги пользователям можно осуществлять немедленно. Примером (рис.1) может служить удовлетворение прямого заказа на электронную копию документа.

Интегрированный поиск инорормации через один интерфрейс во множестве разнородных источников, объединенных в сеть, позволяет использовать децентрализованные сервисы, предоставляющие гибкость и свободу действий для заказа по межбиблиотечному обслуживанию.

Заключение

Статья подводит некоторые итоги по изу-

\footnotetext{
${ }^{1}$ Иитерфрейс (англ. Interface) - совокупность технических и программных средств, обеспечивающих взаимодействие различных функциональных устройств вычислительных, управляющих или измерительных систем (например, оперативного и внешнего запоминающих устройств ЭВМ). Интерфейс позволяет набирать системы из готовых модулей в соответствии с установленными правилами и соглашениями в отношении кодирования и синхронизации передаваемой информации, механические и электрические соединения устройств, вида сигналов, формы представления информации и т. д. [Современная энциклопедия. 2000. URL: https://dic.academic.ru/dic.nsf/enc1p/19890 (дата обращения 14.10.2020)].
} 
чению систем и инструментов поиска инорормации, которые открывают пользователям межбиблиотечных услуг богатые инорормационные ресурсы, предоставленные разнородными ИПС. Они отличаются наполнением контента, целевым назначением, функциональными возможностями, одновременно дополняют друг друга и преследуют общие ориентиры на пользовательские запросы. Поисковые процедуры могут дополняться и изменяться в зависимости от вида ресурса, специфики ИПС, инструментов, методов, задач поиска, накопленного опыта пользователя и определённых условий, выдвигаемых владельцами ресурсов.

Новые разработки интеграционных систем поиска позволяют развивать полностью децентрализованные сервисы, которые можно осуществлять в межбиблиотечном обслуживании, если просто запустить дополнительные приложения к программному обеспечению без дальнейшего ввода каких-либо данных для подключения.

Пользователи межбиблиотечных услуг стоят перед проблемами изменчивости обстоятельств, факторов, выбора систем и стратегий для релевантного поиска информации. Поэтому они нуждаются со стороны инорормационных и библиотечных служб в помощи выбора ИПС и вариативных стратегиях разыскания по интересующим темам.

\section{Список источников}

1. Список крупнейших библиотек мира. URL:https://dic.academic.ru/dic.nsf/ruwiki/1534034 (дата обращения: 15.04.2020).

2. ГОСТ 7.73-96 Система стандартов по информации, библиотечному и издательскому делу. Поиск и распространение информации. Термины и определения. URL: https://allgosts.ru/01/140/gost_7.73-96 (дата обращения: 30.03.2020).

3. Скарук Г. А. Электронный каталог как посредник поискового взаимодействия между автором и читателем // Девятые
Макушинские чтения : материалы науч. конф., 15-16 мая 2012 г., Барнаул. Новосибирск : ГПНТБ СО РАН, 2012.С. 356-359.

4. Скарук Г.А. Средства и методы помощи пользователям электронного каталога в самостоятельном поиске // Тр. ГПНТБ СО РАН. Вып. 8. Новые направления деятельности традии. б-к в электрон. среде : материалы межрегион. науч.-практ. конф. (22-26 сентября 2014 г., Красноярск). Новосибирск, 2015. С. 275-282.

5. Скарук Г. А. Читательский поиск в электронном каталоге: итоги анализа поисковой статистики ГПНТБ СО РАН. Научные и технические библиотеки. 2017. № 12. C. 63-72. https://doi.org/10.33186/10273689-2017-12-63-72.

6. Golub K. Subject Access in Swedish Discovery Services // Knowledge organization. 2018.45, 4. P.297-309.

7. Брумштейн Ю. М., Васьковский Е. Ю., Куаншкалиев Т. Х. Поиск информации в Интернете: анализ влияющих факторов и моделей поведения пользователей // Известия ВолГТУ. 2017. № 1. С. 50-55.

8. Литвинова Н. Н. Как пользователи находят статьи из научных журналов в электронной среде // Научные и технические библиотеки. 2019. № 1. C. 30-39. https://doi.org/10.33186/1027-3689-2019-1-30-39.

9. Arshad Alia, Ameen Kanwal. Scholarly in-formation seekingof Academic Engineers and Technologists // International Information and Library Review. 2019. 51, № 1. P. 1-8. DOI:: 10.1080/10572317.2018.1425970.

10. McCollough A. Does It Make a Sound: Are Open Access Monographs Discoverable in Library Catalogs? URL: https://muse.jhu. edu/article/645358/pdf (дата обращения: 03.05.2020).

11. Teixeira Lopes C., Paiva D., Ribeiro C. Effects of language and terminology of query suggestions on medical accuracy considering different user characteristics // Journal of the Association for Information Science and Technology. 2017. 68, № 9. P. 2063-2075; https://doi.org/10.1002/asi.23874.

\section{Поисковые}

процедуры могут

дополняться и

изменяться

в зависимости

от вида ресурса, специфики ИПС, инструментов, методов, задач поиска,

накопленного опыта пользователя и определённых условий, выдвигаемых владельцами ресурсов

Пользователи межбиблиотечных услуг стоят перед проблемами изменчивости обстоятельств, фракторов, выбора систем и стратегий для релевантного поиска инорормации

Ирина Красильникова - Россия Фанлар Академиясининг Сибирь Давлат илмий-техника кутубхонасининг илмий-технология бўлими катта илмий ходими, педагогика фанлари номзоди.

Мақолада ахборот-кутубхона муассасаларида босқцчма-босқцч йўлга куйилаётган электрон каталоглар орқали қидирув тизимларининг мавжудлиги, ташқи манбалардан маълумот излаш зарурияти туфайли фондларда электрон ресурслар сонини кўпайтириш ва тегишли хужжатлар билан таъминлаш масалалари ёритилган. Каталоглар х,амда бошқа қидирув тизимлари орқали маълумотларни қидириш доимо кутубхоналараро алмашинув хизматига нисбатан, буюртмаларни бажарилишида пешқадам булган. Мақоланинг мақсади хам бир неча турдаги қидирув тизимларини ўрганиш орқали ўрганилаётган мавзу буйича янги илмий нашрларни умумлаштиришга қаратилган. 


\section{ТРАНСФОРМАЦИЯ}

БИБЛИОТЕКИ КИЕВСКОГО

НАЦИОНАЛЬНОГО

УНИВЕРСИТЕТА КУЛЬТУРЫ

И ИСКУССТВ В НАУЧНО-

ИНФОРМАЦИОННЫЙ ЦЕНТР

\section{dof $10.47267 / 2181-8207 / 2020 / 3-027$}

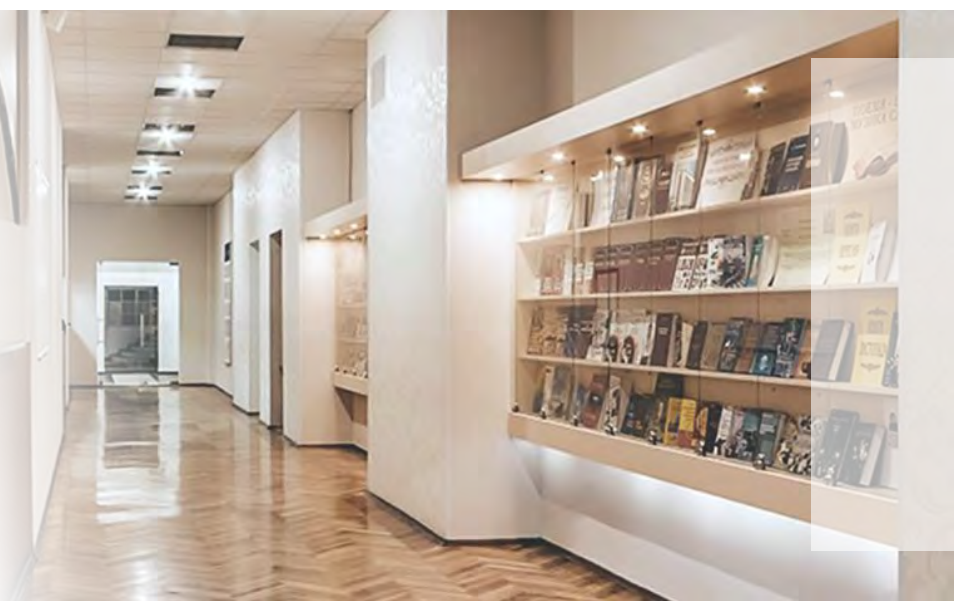

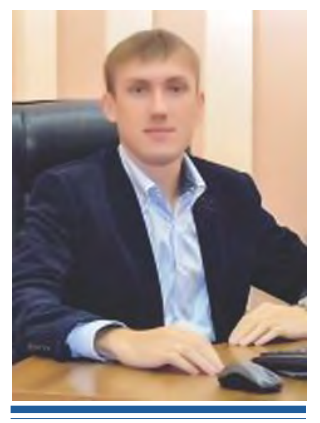

Юрий Горбань, директор Научной

библиотеки

Киевского

национального

университета

культуры и искусств,

кандидат

культурологии,

доцент

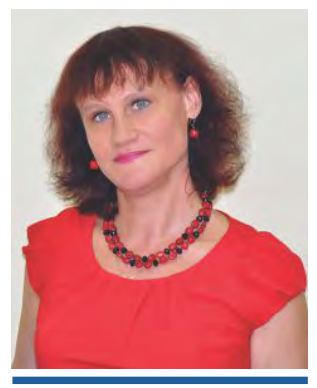

Елена Скаченко,

заведующая

сектором

Научной библиотеки

Киевского

национального

университета

культуры и искусств

The article examines the tasks and forms of library participation in the information support of scientific research at the university. The authors of the article describe the experience of transforming the traditional activities of the library of the Kyiv National University of Culture and Arts (Ukraine), which turned it into a scientific and information center of a higher educational institution. The authors come to the conclusion that the KNUKil library is an important participant in the formation of the university's scientific brand, actively contributes to the integration of its scientific potential into the international community of scientific communication.

Keywords: university library, scientific communication, open access, scientific periodicals, scientific and publishing activities

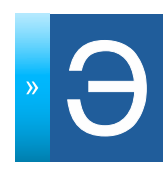
пидемия COVID-19 глобально повлияла на развитие общества и его гуманитарную сореру. Библиотеки не остались в стороне от изменений, они ищут новые формы, направления и методы работы. Ключевыми словами профрессионального развития и грамотности в современном обществе стали: инсрормация, знания, визуализация и коммуникация. «Привлечение библиотечных сотрудников к инфрормационному обеспечению научных исследований, которые переходят в другую плоскость - электронную, будет способствовать развитию библиотек на другой концептуальной основе» [3, с. 3].

В создавшихся условиях научная библиотека Киевского национального университета культуры и искусств (далее - КНУКиИ) постепенно трансформируется в научно-информационный центр, главными задачами которого является фрормирование интеллектуальных ресурсов и продвижение их в инорормационно-образовательную систему университета и мировое научное пространство. Первоочередной стала фрункция предоставления доступа к инорормационным ресурсам отечественной и мировой науки, обеспечение качества учебного процесса, научной деятельности университета.

Глобальное распространение инорормационных технологий актуализировало проб- лему фрормирования открытого доступа как эфрфективного способа обмена инорормацией в сорере образования и науки. Поэтому, с 2017 года библиотека организует и сопровождает развитие университетского репозитария, содействуя повышению рейтинга высшего учебного заведения через предоставление собственной научной продукции в сети Интернет и повышения индекса цитирования.

Репозитарий академических текстов как новая модель научных коммуникаций в библиотеке КНУКиИ фрормируется с сентября 2017 года на базе договоров с научно-педагогическими работниками университета, используя автоматизированную библиотечную информационную систему «УФД-Библиотека». Насчитывает около 6000 документов (монографиии, учебные пособия, учебники, учебно-методические комплексы, рабочие программы). Библиотека выполняет функции администратора электронного архива по наполнению и редактированию информации и, в отличии от отдельных университетов, включает в репозитарий только научные издания университета [2, с. 67].

В сорере информационного обеспечения развития образования и науки библиотека тесно сотрудничает с Научно-исследовательским институтом, научным отделом и касредрами университета. В рамках информаци- 
онной поддержки научных исследований библиотека создает и предоставляет релевантную инфрормацию для научных работников, защищающих кандидатские и докторские диссертации в ученых советах университета:

Специализированный ученый совет Д 26.807 .02

26.00.01 - теория и история культуры (культурология, искусствоведение).

Специализированный ученый совет К 26.807.03

17.00.01 - дизайн (искусствоведение).

Специализированный ученый совет К 26.807.04

27.00.03 - книговедение, библиотековедение, библиографоведение (социальные коммуникации);

27.00.05 - теория и история издательского дела и редактирования (социальные коммуникации);

27.00.06 - прикладные социально-коммуникационные технологии (социальные коммуникации).

Ведущим направлением деятельности научной библиотеки стало внедрение библиометрических и наукометрических методов. C целью поддержания полноты и оперативности презентации результатов научной деятельности ученых университета, сотрудники библиотеки:

\section{- Инфрормируют об инструментах и мето- дологии наукометрии; \\ - Проводят научные семинары и круглые столы о специфрике работы с наукометри- ческими базами данных; \\ - Создают профили ученых в реестре уникальных идентификаторов ORCID (Open Researcher and Contributor ID); \\ • Проводят индивидуальные и групповые консультации по офрормлению научных статей, литературных источников; \\ - Совершают исследование публикаци- онной активности и цитирования научных трудов ученых.}

В 2016 году, с целью предоставления ученым университета быстрого способа отслеживания цитирования их статей, сотрудники библиотеки совершили регистрацию библиометрических профилей научно-педагогических работников университета в некоммерческой международной поисковой системе Google Scholar и ORCID. На протяжении 2017-2018 годов авторские профили были отредактированы и упорядочены с целью установления перекрестных связей между ними.
Вопросы использования баз данных научного цитирования (поиск публикаций отдельных авторов, присоединение публикаций к профрилю, верификация учреждений в публикациях, расчет индекса цитирования автора и импакт-фрактора журналов, где он публикуется) являются предметом постоянного мониторинга и консультаций.

Также начата работа с библиографической и реферативной базой данных Scopus и наукометрической реферативной базой данных Web of Science для оценки эфрфективности университетской науки, повышения рейтинга учебного заведения, фрормирования бренда ученых.

Учитывая современные требования к развитию науки и принципы «Стандартов и рекомендаций для обеспечения качества в Европейском пространстве высшего образования (ESG), с ноября 2017 года библиотека участвует в формировании внутренней системы качества образования в университете, а именно - выполняет процессы, направленные на обеспечение ученых, преподавателей, аспирантов и студентов университета качественными инфрормационными ресурсами для развития открытого доступа и поддержки честного научно-образовательного процесса. Во избежание злоупотреблений в научной среде, библиотека принимает активное участие в Проекте содействия академической честности в Украине (SAIUP). Для магистров и аспирантов университета сотрудниками библиотеки организуются практические занятия и мастер-классы по вопросам изучения признаков плагиата, фоомирования навыков поиска и работы с первоисточниками, корректного офрормления цитат и за-

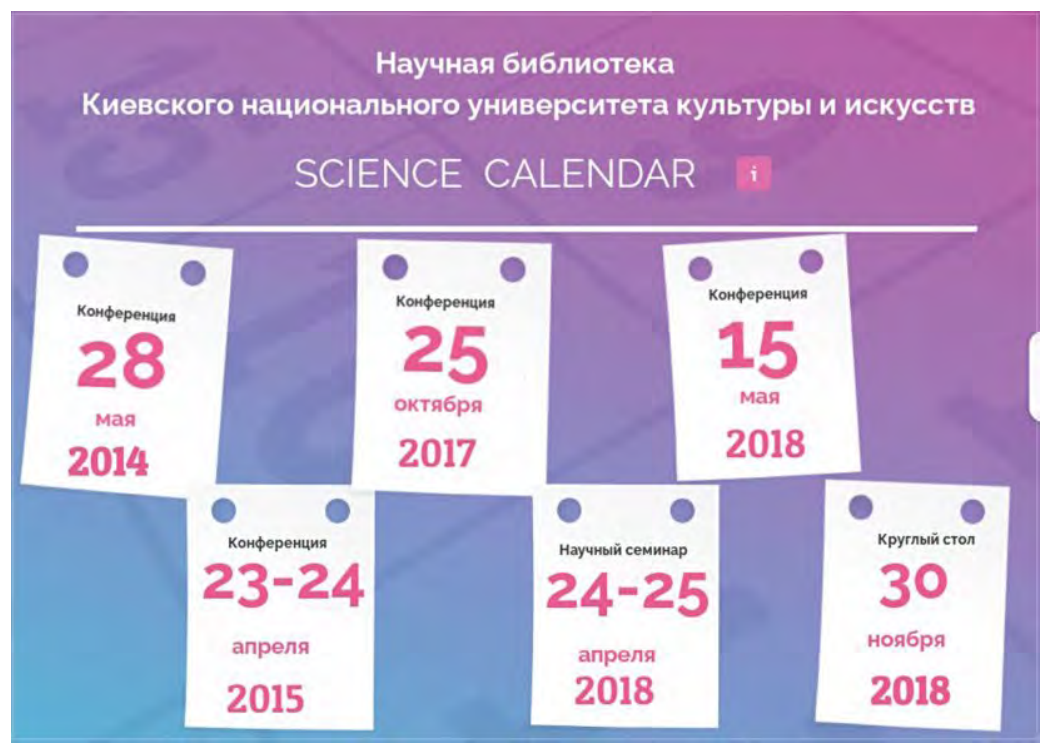

\section{Вопросы}

использования баз

данных научного

цитирования

(поиск публикаций

отдельных авторов,

присоединение

публикаций

верификация

учреждений

в публикациях,

расчет индекса

цитирования автора

и импакт-орактора

журналов, где он

публикуется)

являются предметом

постоянного

мониторинга и

консультаций к профрилю, 
БІБЛІОТЕКА:

КУЛЬТУРНИЙ ПРОстІР

ТА ІННОВАЦІЙНИЙ ПОСТУП

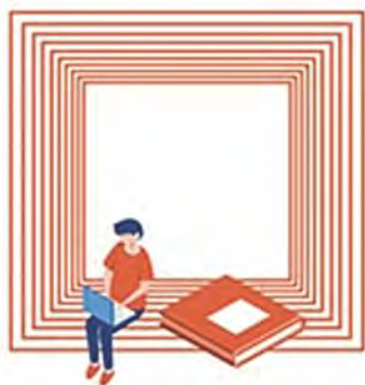

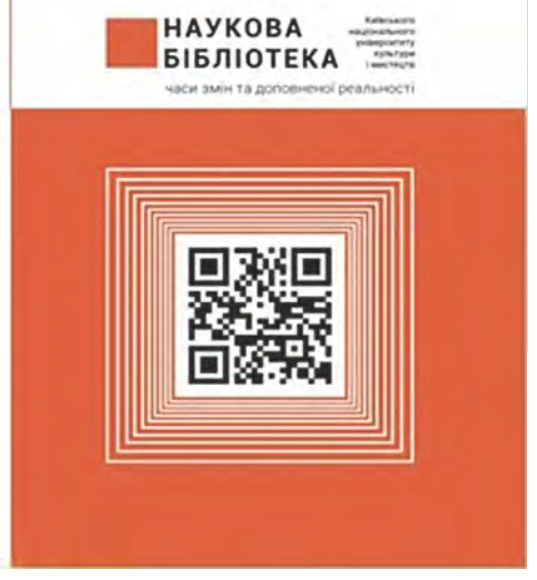

имствований. Обязательным требованием в университете стала проверка сотрудниками библиотеки всех научных работ при помощи онлайн сервиса поиска плагиата Unicheck.

Общеизвестно, что устоявшимися фрунк-

Широко используя

возможности

цифрровых

технологий

библиотека

продолжает

трансорормировать

традиционные

ресурсы и услуги.

Главным

электронным

информационным

продуктом и

популярным

библиографии-

ческим ресурсом

библиотеки

является

электронный

каталог

циями университетской библиотеки в целом являются сбор, систематизация, хранение информации, предоставление свободного доступа к инфрормационным источникам. Однако преобразования, произошедшие в информационной среде, изменили фрорматы распространения информации, актуализировали необходимость внедрения инновационных технологий и трансформации информационно-библиотечного обеспечения научных исследований в университете. Важное значение приобрела работа с 16 научными периодическими изданиями университета, их издательская и редакционная поддержка, продвижение в международные базы данных. Сотрудничая с редакционными коллегиями журналов в течение 2018 - 2019 годов, библиотекой проведена работа по получению для научных изданий идентификаторов ISSN (print), ISSN (online) и сертификатов в Международном центре ISSN (Франция).

Для облегчения поиска научных публикаций этих журналов в электронном научном массиве, совершается процедура присвоения статьям цифрового идентификатора объектов (DOI). По состоянию на 2020 год индекс DOI имеют все статьи научных периодических изданий университета.

Учитывая, что важной частью продвижения нового научного издания является наличие содержательного веб-сайта, который является визитной карточкой журнала, - сотрудники отдела информационных технологий научной библиотеки для каждого издания на международной издательской плат- форме Open Journal System (OJS) создали веб-сайт и выполняют его администрирование (размещение метаданных журнальных статей, подготовка инорормационных страниц журнальных номеров, обеспечение целостности базы данных и фрайлов сайта научных журналов, непрерывного доступа к сайту в сети Интернет, создание регулярных резервных копий и т.д.).

С 2014 года библиотека КНУКиИ является офрициальным партнером Украинской библиотечной асоциации (УБА), выступает организатором и соорганизатором научных конференций, семинаров и круглых столов.

Тематика конференций охватывает актуальные направления библиотечного дела, направлена на изучение опыта работы, внедрение инноваций, определение перспектив дальнейшего развития. Участниками I Всеукраинской научно-практической конференции «Инновационнная деятельность - стратегическое направление развития библиотек высших учебных заведений», состоявшейся в 2014 году, стали 127 библиотечных специалистов из Киева, Харькова, Луганска, Сум, Ровно. В следующем 2015 году библиотека совместно с кафедрой книговедения и библиотековедения КНУКиИ организовала и провела Всеукраинскую научно-практическую конореренцию «Библиотека XXI: перспективы и инновации». 24-25 апреля 2018 года библиотека инициировала и с участием УБА и кафредры инорормационных технологий КНУКиИ, под патронатом Министерства культуры Украины, провела научный семинар «Библиотека. Книга. Наука». Участниками семинара стали более 100 специалистов из Киева, Львова, Днепра, Николаева, Кривого Рога, Полтавы, Александрии, которые представляли национальные библиотеки и государственные институты, 18 библиотек учебных заведений Украины, научно-исследовательские институты, общественные организации и издательства.

Широко используя возможности цифровых технологий, библиотека продолжает трансорормировать традиционные ресурсы и услуги. Главным электронным инорормационным продуктом и популярным библиографиическим ресурсом библиотеки является электронный каталог (далее - ЭК), фрормирование которого начато в 2000 году на базе системы ИРБИС и продолжено в 2012 году на базе АБИС «УФД-Библиотека». Каталог содержит описание различных видов документов: книг, методических пособий, учебных мате- 
риалов, периодических изданий, диссертаций, авторефератов диссертаций, нотных изданий, статей из периодических изданий и сборников научных работ. Также ЭК предоставляет доступ к полнотекстовой коллекции электронной библиотеки (далее - ЭБ), которая орормируется путем оциорровки документов, передачи электронных копий печатных изданий, подготовленных учеными университета и сотрудниками библиотеки. Электронная библиотека - универсальная по содержанию и состоит из более 6000 документов на сервере библиотеки. Право пользования полнотекстовыми документами библиотеки имеют зарегистрированные читатели при введении личного пин-кода и шифра. Доступ до ЭБ возможен через ЭК с библиотечного веб-сайта.

Не менее важным информационным ресурсом является веб-сайт библиотеки, функционирование которого начато в 2015 году. Наличие веб-сайта предоставило возможность обслуживания отдаленных пользователей при помощи сервисов «Виртуальная справка» и «Электронная доставка докуменTOB».

Свои традиции и задачи имеет научно-издательская деятельность библиотеки, активизировавшаяся в последние 10 лет.

Важным путем промоции научного и творческого потенциала университета является персональная библиография. Библиографирование научного наследия ученых университета стало базой издания персональных указателей, объединенных в серии: «Выдающиеся личности КНУКиИ» (основана в 2012 году), «Ученые КНУКиИ» (2013), «Знаменательные события КНУКиИ» (2013). Текущее библиографрирование работ научно-педагогического персонала университета осуществляется в ежегодном указателе «Печатные работы преподавателей КНУКиИ» (первый опубликован в 2011 году).

К 50-летию основания университета в 2018 году библиотека подготовила библиограсрические указатели:

- «Диссертации, защищенные в Киевском национальном университете культуры и искусств 1993 - 2018 гг.) (содержит сведения о защищенных диссертациях на получение ученых степеней кандидатов культурологии, искусствоведения, социальных коммуникаций, педагогических, исторических наук, а также докторов культурологии и искусствоведения по разным специальностям);

- «Киевский национальный университет

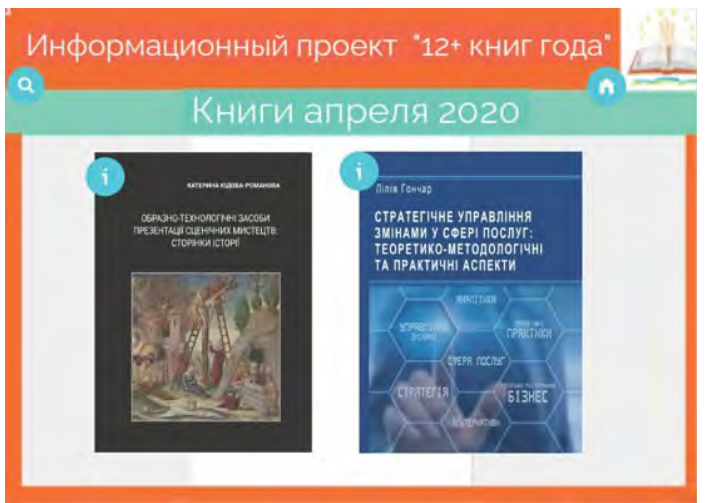

культуры и искусств на страницах периодических изданий 1976 - 2016 гг.» (систематизирует публикации о выдающихся событиях в жизни университета, о преподавателях, студентах, выпускниках, творческих коллективах и художественных проектах университета за период с 1976 по 2016 годы).

В 2018 году библиотека основала серию «Научные школы КНУКиИ», первым изданием которой стала антология «Книговедческая школа Киевского национального университета культуры и искусств». Антология состоит из 7 разделов и в биобиблиограсрических очерков об ученых - выпускниках Киевского национального университета культуры и искусств - отображает важные вехи развития книговедения, библиотековедения, библиограсроведения Украины конца XX - начала XXI века, сохраняет их научно-педагогические наработки.

Издание этих и других научно-вспомогательных указателей, во-первых, содействует популяризации трудов преподавателей университета (ученых и деятелей искусств); вовторых, является эффрективным способом сохранения научного наследия университета; в-третьих, каждый указатель является результатом научно-инорормационной деятельности библиотеки, показателем высокого профрессионализма ее коллектива [1, с. 182].

K собственному 55-летнему юбилею библиотека подготовила два издания: исторический очерк «Научная библиотека Киевского национального университета культуры и искусств: времена перемен и дополненной реальности» и сборник избранных статей сотрудников за 2012 - 2018 годы «Библиотека: культурное пространство и инновационный прогресс». В статьях рассматриваются актуальные вопросы современного библиотековедения, библиограсроведения, книговедения; проблемы управления деятельностью библиотек; освещен опыт библиотеки КНУКиИ в инфрормационно-библиографической,
Не менее важным инорормационным ресурсом является веб-сайт

библиотеки, функционирование которого начато в 2015 году. Наличие веб-сайта предоставило возможность обслуживания отдаленных пользователей при помощи сервисов «Виртуальная справка» и «Электронная доставка документов»

Важным путем промоции научного и творческого потенциала университета является персональная библиограсрия. Библиографирование научного наследия ученых университета стало базой издания персональных указателей 
Библиотека

КНУКи-И фрунции

промоции

результатов

научно-

издательской

деятельности

ученых

университета

реализует

в рамках

инорормационного

проекта

«12+книг года»

Современные

вызовы

сорормировали

новую миссию

библиотеки -

инорормационного

менеджера и

посредника,

разработчика

электронных

ресурсов и

продуктов; привели

к изменениям

в деятельности

библиотеки,

по-степенно

трансорормировав

ее в научно-

информационный

центр

университета инновационно-методической, проектной деятельности, библиотечном обслуживании, формировании документных ресурсов и внедрении инорормационных технологий.

Учитывая, что современные пользователи все более активно взаимодействуют с миром при помощи гаджетов, библиотеки стремятся использовать новые, конвергентные форматы коммуникации с ними. Библиотека КНУКиИ фунции промоции результатов научно-издательской деятельности ученых университета реализует в рамках информационного проекта «12+книг года». Задачами проекта являются ежемесячное информирование научной общественности о новых изданиях по инорормационному, музейному, издательскому, гостинично-ресторанному делу, туризму; аудиовизуальном, сценическом, музыкальном, хореографическом искусстве, графическом дизайне и т.д., изданные учеными университета в текущем году и присутствующие в библиотечном фонде [4,с.158-159]. Книги презентуются при помощи цифрового интерактивного плаката, созданного в приложении Genial.ly [5].

Современные вызовы сорормировали новую миссию библиотеки - информационного менеджера и посредника, разработчика электронных ресурсов и продуктов; привели к изменениям в деятельности библиотеки, постепенно трансорормировав ее в научно-информационный центр университета. Среди первоочередных задач библиотеки выделились: предоставление доступа к информационным ресурсам отечественной и мировой науки, обеспечение качества учебного процесса, научной деятельности университета.

Реализуя поставленные задачи библиотека: предоставляет релевантную инорормацию для научных работников, защищающих кандидатские и докторские диссертации в ученых советах университета; организует и сопровождает развитие университетского репозитария; внедряет библиометрические и наукометрические методы; участвует в формировании внутренней системы качества образования в университете; выступает организатором и соорганизатором научных конореренций по актуальным направлениям библиотечного дела.

Как важный ресурсный и коммуникативный центр, библиотека КНУКиИ принимает активное участие в формировании научного бренда университета, содействует интеграции его научного потенциала в международное сообщество научной коммуникации.

\section{Список источников}

1.Горбань Ю. I. Розвиток університетської бібліотеки: комплекс стратегічних рішень. Вісник Національної академії керівних кадрів культури і мистецтв. 2019. № 2 . C. 180-184.

2. Горбань Ю. Наукова бібліотека Київського національного університету культури і мистецтв: часи змін та доповненої реальності : до 55-річчя від дня заснування / Ю. І. Горбань, О. О. Скаченко ; наук. ред. Т. К. Гуменюк. Київ : Видавниитво Ліра-К, 2019. C. 67.

3. Ржеуський А. Роль бібліотек як соціальних інститутів в інформаційному забезпеченні е-Science / A. Ржеуський, H. Веретеннікова, О. Малиновський, Н. Кунанец, . Бібліотечний вісник. 2016. № 3. С. 3-9.

4. Скаченко О. О. Проект «12 + книг року» як інтерактивна форма візуальної презентації результатів наукових досліджень університету. Бібліотечний Меркуpiŭ. 2020. Bun.1(23). C. 155-168. DOI: https://doi.org/10.18524/2707-3335.2020.1(23).202092

5. 2020. Книги апреля. Библиотека КНУКиИ. https://view.genial.ly/5f61f13779626a0d712862e2/interactive-image-2020knigi-aprelyabiblioteka-knukii

Юрий Горбань - Киевдаги маданият ва санъат миллий университети илмий кутубхонаси директори, маданиятшунослик фанлари номзоди.

Мақола муаллифи университетда ўтказилаётган илмий тадкиқотларни шаклланиши, тадқиқотчиларни бевосита ахборот билан таъминлаб беришда кутубхона олдига куйилган вазифалар хақида мулохаза юритади. Университетнинг илмий кутубхонаси анъанавий фаолиятини ўзгартирган х,олда олий ўкув юртини илмий-ахборот маркази сифатидаги тажрибалари билан ўртоқлашган. Шу билан бир қаторда, илмий бренд яратишда кутубхонанинг илмий салох,ят даражаси халқаро илмий алоқалар доирасида хам ўзгариб бормоқда. Университетнинг илмий фаолияти учун ўқув жараёни сифатини таъминлаш борасида биринчи навбатдаги вазифаси - бу махаллий ва дунё илмий ресурсларидан фойдаланиш имкониятларини яратишдан иборатдир. Таълим сохасини ахборот билан бойитишда университет илмий кутубхонаси қуцшимча равишда илмий-текшириш институти ва илмий ишлар буцйича бўлими билан хам яқиндан хамкорликни йўлга қўйилганлиги таъкидланади.

«INFOLIB» ахборот-кутубхона журнали. №4 (24) 2020 


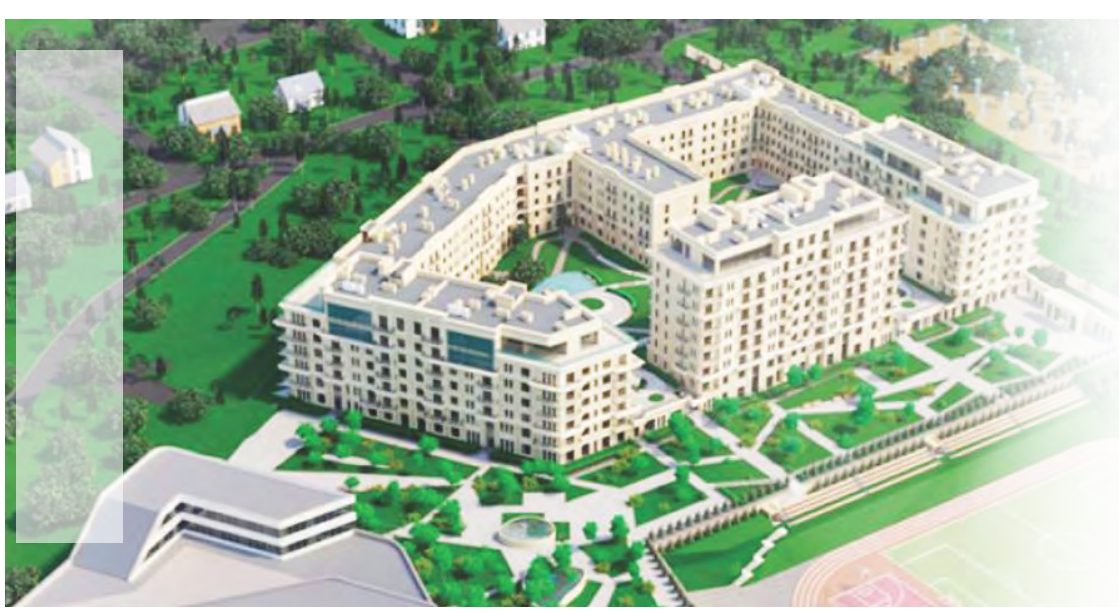

\section{ЭКОСИСТЕМА ИННОВАЦИОННОЙ ИНФРАСТРУКТУРЫ}

\author{
на примере \\ Новосибирской области
}

doi $10.47267 / 2181-8207 / 2020 / 3-028$

The article examines the ecosystem of innovative infrastructure on the example of the Novosibirsk region. Examples of specific elements of the innovation infrastructure are given that are aimed at supporting companies at all stages of creating an innovative product, from generating ideas to launching production. The problem is revealed in the organization of interaction between the elements of the innovation infrastructure. The creation of a single «one window» operator for the effective implementation of the regional policy in the innovation sphere is proposed.

Ключевые слова: инновационная инфрраструктура, инновационная экосистема, управление интеллектуальной собственностью, тройная спираль, единый оператор.

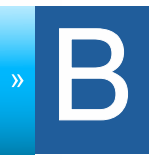

«Стратегии социально-экономического развития Новосибирской области до 2030 года» ${ }^{1}$ особое внимание уделено повышению конкурентоспособности региона. Объем производства к 2030 г. должен достигнуть 1,5 трлн рублей. Для этого должна измениться сама структура экономики региона в сторону глобальных перспективных рынков, обозначенных в Национальной технологической инициативе (далее-НТИ). На прошедшем XI Гайдаровском форуме - 2020 «Россия и мир: вызовы нового десятилетия», Губернатор Новосибирской области Андрей Травников представил региональный опыт создания системы генерации и поддержки технологического предпринимательства, и отметил: «В Новосибирской области есть замечательные примеры того, как фундаментальные научные разработки находят применение не только на уровне стартапов, но и в качестве инноваций в серьёзных промышленных проектах». ${ }^{2}$

Реализация прорывных проектов возможна только на базе научно-технического задела и эффрективной инновационной экосистемы, которая представляет собой совокуп- ность элементов инновационной инораструктуры, включающей в себя различные институты, организации и фрирмы, а также соответствующую им систему управления и координации, достаточных для создания и реализации инновационных проектов.

Подтверждением высокого научно-технического задела Новосибирской области (далее - НСО) является активное участие региона в реализации национального проекта «Наука», а сорормированная за последнее время инновационная экосистема региона позволяет региону входить в группу «Сильные инноваторы» Рейтинга инновационных регионов, разработанного Ассоциацией инновационных регионов России (далее АИРР) совместно с Министерством экономического развития Российской Федерации при участии ведущих экспертов страны. ${ }^{3}$

\section{Управление инновационной деятельностью}

В целях активизации и поддержки инновационной деятельности, от генерации идей до выпуска продукции, особо актуальным в процессе развития региональной инноваци->

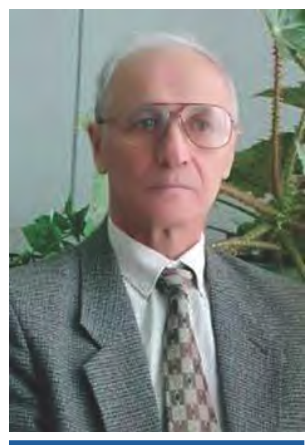

Дмитрий Цукерблат, ведущий научный сотрудник ГПНТБ СО РАН, г. Новосибирск кандидат педагогических наук

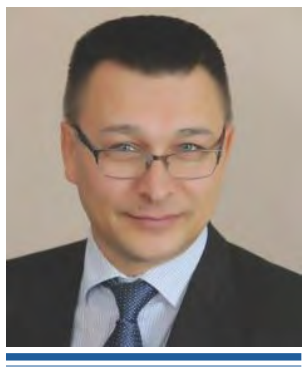

Александр Николаенко, зам. директора по инновационной деятельности ИХТТМ СО РАН, г. Новосибирск

'Постановление Правительства Новосибирской области от 19.03.2019 № 105-п «О Стратегии социально-экономического развития Новосибирской области на период до 2030 года».

${ }^{2}$ Губернатор Андрей Травников: Синхротрон СКИФ - это сверхзадача, сопоставимая с крупнейшими советскими проектами. URL: https://www.nso.ru/news/ 39385 (дата обращения: 16.04.2020).

${ }^{3}$ Рейтинг инновационных регионов России. URL: http://i-regions.org/reiting/rejting-innovatsionnogo-razvitiya/ (дата обращения: 16.04.2020). 
С 1990 года

в ННЦ происходит

перестройка и

реформирование

системы взаимоде-

йствия всех

субъектов научной,

технической и

инновационной

деятельности,

фрормируется

инновационная

инфраструктура

\section{В Новосибирске}

был создан

консорциум

«Сибнанотех»,

участниками

которого стали

54 организации,

выполняющие

работы в области

нано-технологий онной экосистемы становится создание недостающей инфраструктуры и формирование связей между всеми специализированными организациями, выступающими в качестве элементов единой экосистемы.

На основе созданной инновационной экосистеме гораздо проще возникнуть успешному инновационному бизнесу, готовому к сотрудничеству с научными и образовательными организациями. Ключевыми элементами успеха при этом являются межличностные отношения и доверие. Партнерские отношения между различными элементами инновационной среды представляют собой в первую очередь связи между отдельными людьми. Не организации сотрудничают между собой сотрудничают отдельные люди. Накопленный опыт показывает, что представители и науки, и образования, и бизнеса открыты к диалогу и готовы к сотрудничеству.

Научно-образовательная подсистема

Новосибирская область обладает огромным научно-исследовательским потенциалом. Особое положение занимает Новосибирский научный центр (далее - ННЦ) - компактная территория (Академгородок, наукоград Кольцово, г. Бердск, р.п. Краснообск) с высокой концентрацией научно-технологического, научно-образовательного потенциала и уникальных компетенций мирового уровня, что позволяет реализовывать междисциплинарные научные проекты.

С 1990 года в ННЦ происходит перестройка и реформирование системы взаимодействия всех субъектов научной, технической и инновационной деятельности, фрормируется инновационная инораструктура. Регион является одним из крупнейших образовательных центров России. Организации высшего образования региона поставляют организациям и предприятиям квалифицированные кадры практически по всем направлениям научных исследований. Институты Сибирского отделения РАН (далее - СО РАН) предоставляют оборудование, площади для проведения научных исследований, а также направляют своих сотрудников в качестве преподавателей. Они взаимодействуют с предприятиями и организациями высшего образования, на базе научных разработок создаются малые инновационные предприятия.

НИИ СО РАН кроме государственного задания выполняют для предприятий и организаций внебюджетные работы (консультации по отдельным вопросам организации произ- водства и совершенствования технологического процесса, независимые экспертизы, технические расчеты, использование оборудования института или университета для проведения отдельных измерений и испытаний и т.п.). Несмотря на разовый характер услуг, качественный научно-технический сервис, безусловно, способствует укреплению партнерских и личных связей, повышению инорормированности хозяйствующих субъектов об инновационном потенциале НИИ и университета, распространению сведений о возможностях НИИ, что создает предпосылки для долгосрочного сотрудничества и получения новых заказов.

\section{Подсистема интеллектуальной}

\section{собственности}

В рамках развития инновационной деятельности Российская Федерация формирует и реализует политику, направленную на эфорективное использование результатов интеллектуальной деятельности (далее РИД). В процессе совершенствования инновационной политики Правительство Российской Федерации разработало пакет документов о создании федеральных целевых программ (далее - ФЦП). Так, например, начиная с 2008 г. в соответствии с ФЦП «Развитие инфрраструктуры нанотехнологий» в России начала создаваться национальная нанотехнологическая сеть (далее - ННС). Стратегической целью создания ННС было объявлено обеспечение достижения и поддержания паритета России с экономически развитыми странами в сорере нанотехнологий. В Новосибирске был создан консорциум «Сибнанотех», участниками которого стали 54 организации, выполняющие работы в области нанотехнологий.

В ходе реализации проекта в Новосибирской области были получены положительные результаты: собрана, проанализирована и размещена в базе данных инорормация о НИОКР в области нанотехнологий, о развитии региональной наноиндустрии. В рамках проекта осуществлялись бесплатные услуги для научно-образовательных организаций по офрормлению патентов, заключению лицензионных соглашений, проведению маркетинговых исследований, доступу к информационным базам данных и т.д. Были разработаны методические пособия по коммерциализации РИД. В настоящее время работы продолжаются на базе нанотехнологического центра «Сигма-Новосибирск». 
Сбалансированная система управления ИС, означающая гибкое сочетание интересов правообладателей и пользователей, представляет собой важную составную часть нормально фрункционирующей экосистемы инноваций. Как справедливо отмечает Видякина О.В., «вне зависимости от того, на базе какой модели формируется «инновационная экосистема», имеет значение система управления интеллектуальной собственностью, как неотъемлемая часть инновационной экосистемы».

Данная система позволяет не только генерировать технологические инновации, но и успешно их передавать как на национальном, так и на международном уровнях. В этой связи Роспатент оказывает техническую помощь в применении системы ИС для поддержки развития технологий и, по сути, всех остальных звеньев инновационного цикла. Учитывая большой задел интеллектуальной деятельности научно-образовательного комплекса, в НСО был открыт единственный в России орилиал Роспатента (ФГБУ «ФИПС»). Основное направление деятельности - проведение экспертизы заявок на выдачу патентов на полезные модели и подготовка проектов решений Федеральной службы по интеллектуальной собственности (отделы механики и электроники / электротехники.).

С 2012 года на базе Государственной публичной научно-технической библиотеки СО РАН работает региональный Центр поддержки технологий и инноваций (далее ЦПТИ). Новосибирский ЦПТИ предоставляет доступ к высококачественной технической инфрормации и связанным с ней услугам. Благодаря ЦПТИ инноваторы имеют возможность раскрывать свой потенциал, создавать РИД, которым предоставляется правовая охрана, обеспечивать правовую охрану таких объектов и управление правами на ИС. Спектр услуг, оказываемых ЦПТИ, достаточно широк: доступ к патентным (специализированный патентный поиск) и не патентным ресурсам и публикациям по вопросам ИС. ЦПТИ является также и коммуникационной площадкой, организовывая и проводя консультации, тренинги, семинары, конференции по вопросам деятельности в сорере ИС.

\section{Коммуникационная подсистема}

Регион располагает значительным количеством экспертных бизнес-площадок для эфффективных коммуникаций, деловых и социокультурных презентаций общественно- важных проектов. Наряду с региональными активно используются площадки фредерального и международного уровней, которые обосновались в Новосибирске. Достаточно вспомнить ежегодно проводимый Международный фрорум-выставка технологического развития «ТЕХНОПРОМ», мероприятия которого объединяют на своей площадке ведущих российских исследователей и разработчиков, отвечающих на вызовы научно-технологического развития страны. По мнению экспертов: «На нем традиционно принимают решения, влияющие на развитие экономики всей страны, выступают чиновники высшего уровня, главы компаний-лидеров отрасли, презентуют новейшие инновационные разработки и привлекают миллиарды инвестиций в высокотехнологичные и инновационные стартапы».

Для организации нефрормальных встреч профрессиональных сообществ, а так же проведения деловых фрорумов, конференций и хакатонов в НСО запущено три «Точки кипения» (Академпарк, Новосибирский государственный технический университет, Новосибирский государственный университет экономики и управления) по фрормату, предложенному Агентством стратегических инициатив. Основные направления мероприятий это вопросы подготовки кадров для рынков будущего, перспективы развития передовых производственных технологий, создание энергетики на новых принципах функционирования, разработка продуктов, обеспечивающих рост продолжительности и повышение качества жизни, интеллектуальные системы управления транспортом.

\section{Подсистема трансфера технологий}

Во многих направлениях институты РАН продолжают выполнять работы мирового уровня. Однако при этом сохраняется недостаток спроса со стороны промышленных предприятий. По существу сотрудничество науки, организаций высшего образования и промышленных предприятий по вопросам создания и использования РИД, как правило, различается причинно-следственными связями.

Первый путь работает по принципу «толчка», когда научная деятельность сотрудников НИИ и университета выполняется согласно собственным планам развития, по типу открытых инноваций. В результате таких работ создаются образцы новой высокотехнологичной продукции, внедрение которых тре-
Благодаря ЦПТИ

инноваторы имеют

возможность

раскрывать свой

потенциал,

создавать

РИД, которым

предоставляется

правовая охрана, обеспечивать

правовую охрану таких объектов

и управление

правами на ИС

Международный форум-выставка технологического развития «ТЕХНОПРОМ», мероприятия которого объединяют на своей площадке ведущих российских исследователей и разработчиков, отвечающих на вызовы научнотехнологического развития страны 
Один из «старейших» бизнесинкубаторов (далее - БИ)

региона - бизнесинкубатор

Академпарка с 2010 года

поддерживает

и развивает

технологические

стартапы

В 2019 году

в бизнес-

инкубаторе было

94 компании-

резидента,

в них работает

516 человек,

а совокупная

выручка составила

477 млн руб. бует значительных затрат, изменения технологического цикла, и поэтому востребовано в первую очередь малыми инновационными предприятиями, выпускающими единичную продукцию.

Второй путь работает по принципу «тяги». Этот путь коммерциализации РИД и созданной ИС предполагает, что инициатива исходит от предприятия, которое заказывает НИОКР у НИИ или университета, заключая договор, связанный с решением прикладных задач конкретного заказчика. Промышленные предприятия обычно не заказывают разработку совершенно новой продукции. Чаще результатом НИОКР является усовершенствование уже выпускаемой продукции или уже работающей технологии.

Опыт показывает, что кооперация участников системы создания знаний и инноваций, представителей науки и образования, бизнеса и государственной власти может не только повысить конкурентные преимущества участников (в своей области интересов), но и создать синергетические эффректы, способствуя росту занятости, развитию новых высокотехнологичных производств и коммерциализации разработок. Этому содействуют основные элементы инновационной инфраструктуры, которые в т.ч. направлены на трансфер технологий:

- Новосибирский областной фонд поддержки науки и инновационной деятельности, в течении последних 10 лет плотно «упаковывает» проекты для Сибирской Венчурной Ярмарки.

- Индустриальный офрис Академпарка осуществляет систему мероприятий по внедрению новых технологических решений и результатов проектной деятельности в промышленность, помогает преодолевать «технологические барьеры», имеющиеся на предприятиях.

- Центр трансорера технологий и коммерциализации НГУ обеспечивает комплексное развитие инновационной экосистемы университета, содействует синхронизации работы с объектами инновационной инорраструктуры региона, а также устанавливает кооперационные связи НГУ с высоко-технологичным бизнесом.

- Среди бизнес-акселераторов можно выделить А:СТАРТ, признанной одной из лучших акселерационных программ в России, благодаря которой с 2010 года в Академпарке создаются и развиваются инновационные стартапы в области медицины,
ИТ, приборо-строения, нано- и биотехнологий. Проект помог запустить 210 успешных стартапов. Например выпускник А:СТАРТа Андрей Загоруйко, сотрудник Института катализа им. Г.К. Борескова СО РАН, с проектом по разработке технологии для утилизации жидких токсичных органических и хлорорганических отходов стал по итогам 2019 г. победителем в номинации «Стартапер года» премии журнала «Деловой квартал».

Такие примеры многократно подтверждают тот фракт, что НИИ СО РАН были и остаются одним из главных источников инновационных идей и технологий. Однако сегодня важно не только создавать систему, которая способна генерировать проекты, но и могла быподдерживать их технологически.

\section{Технологическая подсистема}

Для старта реализации инновационных идей и технологий в Новосибирской области сорормирована значительная сеть бизнесинкубаторов: Бизнес-инкубатор Академпарка, Нанотехнологический центр «СИГМА. Новосибирск», Бизнес-инкубаторы города Новосибирска и р.п. Кольцово.

Один из «старейших» бизнес-инкубаторов (далее - БИ) региона - бизнес-инкубатор Академпарка с 2010 года поддерживает и развивает технологические стартапы. В первую очередь, БИ привлекает недостающие интеллектуальные и материальные ресурсы необходимые для эффрективного продвижения и скорейшего вывода продукта на рынок. В 2019 году в бизнес-инкубаторе было 94 компании-резидента, в них работает 516 человек, а совокупная выручка составила 477 млн руб..

Безусловно, что стартапам в сорере приборостроения, биомедицины и новых материалов для изготовления прототипа необходимо дорогостоящее технологическое оборудование. На решение этой проблемы направленны созданные в регионе следующие специализированные центры: инжиниринговые центры, центры прототипирования, испытательные лаборатории, Центр технологического обеспечения, Центр информационных технологий, Центр наномодифицированных материалов, Испытательный лабораторный центр Биотехнопарка Кольцово, Центр прототипирования Медицинского Технопарка, Инжиниринговый медико-технологический центр и Региональный центр нормативнотехнической поддержки инноваций Новоси- 
бирской области. Необходимыми объектами технологической инфраструктуры, направленными на создание наилучших условий для успешного развития действующих высокотехнологичных предприятий, являются технопарки. Они представляют собой имущественный комплекс, который обладает уникальной технологической и деловой инфраструктурой. В НСО реализуется три технопарковых проекта: Академпарк, Медицинский Технопарк и Биотехнопарк Кольцово. Результаты их деятельности подвела Ассоциация кластеров и технопарков России в 2019 году. По итогам V Национального рейтинга технопарков, в который вошел 41 технопарк, расположенный в 22 регионах, в группу $\left(A_{+}\right)$«Наивысший уровень эффрективности функционирования технопарка» по результатам исследования вошел новосибирский Академпарк. Такое признание обязывает предпринимать усилия для дальнейшего развития инновационного бизнеса резидентов всех технопарков региона.

\section{Финансовая подсистема}

Прежде чем принять решение о вложении инвестиций в открытие производства, бизнес собирает информацию о состоянии инвестиционного климата в регионе: какой на территории налоговый режим, насколько быстро и прозрачно решаются административные вопросы, связанные с землеотведением, подключение к инженерным сетям и так далее. Наконец, оказывает ли власть давление на бизнес и есть ли фракты недобросовестной конкуренции. И в случае, когда региональная власть гарантирует бизнесу налоговые префреренции, оперативность сопровождения проекта и защиту от недобросовестной конкуренции, он вкладывает деньги в проект.

Конкуренция в поиске инвесторов усиливается год от года. В Новосибирской области на протяжении последних лет определилась позитивная динамика в привлечении инвестиционных проектов, более 6,5 млрд. руб. инвестиций обеспечили проекты, реализуемые Правительством Новосибирской области. Благодаря динамичной работе областного совета по инвестициям удалось значительно повысить эффрективность фринансовой инфрраструктуры поддержки инвестиционных проектов.

Для оказания оринансовой поддержки реализуемых инновационных проектов, на основе государственно-частного партнерства, созданы и успешно работают в Новосибир- ской области следующие фонды: Представительство Фонда содействия инновациям, Представительство Фонда «Сколково», Государственный фронд развития промышленности Новосибирской области, Фонд развития малого и среднего предпринимательства Новосибирской области, Фонд микрофринансирования субъектов малого и среднего предпринимательства.

Важным элементом развитой экономики, наряду с фрондовым и банковским рынками, выступает венчурное инвестирование. Однако оно имеет свои особенности, главная из которых - высокие риски. Тем не менее, российский венчурный рынок развивается, совершенствуя свою инфраструктуру и наращивая фринансовые результаты.

В системе венчурного инвестирования подавляющее большинство бизнес-ангелов являются ключевым звеном в запуске процесса поддержки стартапов, по сути, с самой ранней стадии их развития. Это не просто «денежные мешки», а главным образом профрессионалы, имеющие большой опыт в тех отраслях, куда они инвестируют.

\section{Заключение}

Инновации являются мощным преобразующим фрактором порождая новые отрасли и модернизируя традиционные, этому содействует взаимодействие различных элементов инновационной инфраструктуры. У предприятий появилась возможность вывести товары и услуги на новый уровень, с постоянно расширяющимися внутренним и внешним рынками.

Традиционная модель инновационного развития предполагает полный цикл от генерации идей, проведения исследований и разработок до производства пробной партии инновационного продукта и вывода его на рынок. С точки зрения институциональных фракторов эта модель предполагает задействование многих специализированных организаций для реализации полного инновационного цикла. Это университеты, научно-исследовательские институты, консалтинговые организации, технологические и производственные предприятия и т.д. Часто объединение этих предприятий происходит в форме кластера, холдинга или корпорации.

В Новосибирской области, с учетом приоритетов в научно-технической сорере, инновационный процесс стимулируется государственными органами фредерального и регионального уровня в форме создания иннова-

\section{Благодаря}

динамичной работе областного совета

по инвестициям удалось значительно повысить эороективность фринансовой инорраструктуры поддержки инвестиционных проектов

Важным элементом развитой экономики, наряду с фрондовым и банковским рынками, выступает венчурное инвестирование. Однако оно имеет свои особенности, главная из которых - высокие риски. Тем не менее, российский венчурный рынок развивается, совершенствуя свою инфрраструктуру и наращивая фринансовые результаты 
В регионе

ссрормирована

полноценная

инновационная

инорраструктура,

позволяющая

эмрорективно

реализовывать

потенциал

«тройной спирали»

- взаимодействие

научно-

образовательного

комплекса,

бизнеса и власти ционной инфраструктуры, грантовой поддержки, субсидий и налоговых льгот инновационным компаниям.

В регионе сорормирована полноценная инновационная инораструктура, позволяющая эфроективно реализовывать потенциал «тройной спирали» - взаимодействие научно-образовательного комплекса, бизнеса и власти. Это позволяет Новосибирской области входить в лидеры инновационных регионов России. Однако, нельзя заявлять о том, что в Новосибирской области уже найдено решение главной проблемы современного научно-технологического развития России проблемы разрыва между исследователями, инноваторами и индустрией. Но опыт различных фрорматов решения этой проблемы у нас есть. Для исправления данной ситуации предлагается создание единого оператора «одного окна» для всех участников инновационного процесса, основными задачами которого бы являлись:

• популяризация сореры науки и иннова-
ций;
• развитие среды технологического
предпринимательства;
• организация коммуникаций между
участниками научно-технологической и
инновационной среды;
• оказание методической, организацион-
ной, маркетинговой, фринансовой, иму-
щественной поддержки инновационной
деятельности.
Указанные задачи в приоритетном поряд-

Указанные задачи в приоритетном порядке будут выполнятся в ходе реализации проекта «Академгородок 2.0». Проект создаст условия для развития наукоемкого, инновационного бизнеса и внесет значимый вклад в экономику Новосибирской области.

\section{Список источников}

1. VII Международный форум и выставка технологического развития. Новосибирск, 2019. - URL: https://www.novosibex- ro.ru> event (дата обращения: 16.04.2020).

2. Бизнес-инкубатор Академпарка. Новосибирск, 2020.-URL: https://academpark.$\mathrm{com} /$ projects/biznes_inkubator/ (дата обращения: 16.04.2020).

3. Видякина О.В. Инновационная экосистема: системный анализ // Копирайт. Вестник Российской академии интеллектуальной собственности и Российского авторского общества. - 2020. - №2 - - . 44-51.

4. В Сибири формируется единое научно-образовательное пространство // Поиск. - 2020. - 24 anp.

5. Губернатор Андрей Травников: Синхротрон СКИФ - это сверхзадача, сопоставимая с крупнейшими советскими проектами. - URL: https://www.nso.ru/news/39385 (дата обрашения: 16.04.2020).

6. Данилов Л. В., Кашинова Е. А., Кравченко Е.И., Бухарова М.М., Лабудин М.А., Пятый ежегодный обзор «Технопарки России 2019», Москва:АКИТРФ,2019.С.110.

7. Катковская Ю. «Утокс»: Наука - наше серьезное преимущество // Деловой квартал. - 2020. - № 01 (269). - С. 26-29.

8. Кластер «Сибирский наукополис» в программе развития Новосибирского научного иентра. - URL: https://vn.ru>news-klaster-sibirskiy (дата обращения: 16.04.2020).

9. Марьина А. Новосибирский стартап iFarm по производству овощей в городах привлек 1 млн долл., лид-инвестором сделки выступил венчурный фонд Gagarin Capital // Rusbase. - 2019. - URL: https://rb.ru/news/ifarm-invest/

10. Милогулов Г. Точка кипения - это пространство, где все могут говорить со всеми. - URL: http://www.sib-science.info/ru/news/milogulov-tochka-kipeniya-11022019 12.02.2019 (дата обращения: 16.04.2020).

11. Наука и инновации в Новосибирской области. Статистический сборник / Территориальный орган ФСГС по Новосибирской области. - 2019. - С. 126.

12. Новосибирский научный иентр получит импульс к развитию. - URL: https://www.nso.ru/news/29051 (дата обращения: 16.04.2020).

Дмитрий Цукерблат - Россия Фанлар Академиясининг Сибирь Давлат илмий-техника кутубхонаси етакчи илмий ходими, педагогика фанлари номзоди.

Мақолада Новосибирск вилояти мисолида инновацион инфратузилманинг экотизими ўрганилган бўлиб, унинг ўзига хос элементлари мисолида келтирилган. Шу билан бирга, ишлаб чиқарувчи корхоналар тизимида таклиф қилинаётган вояларни инновацион мах,сулот сифатида амалга оширишгача бўлган жараённинг бажарилиши х,ақида мулох,азалар берилган. Ташкилотларда вужудга келган муаммоларни инновацион инфратузилма элементлари орқали ўзаро бовлаш ва ечимларни самарали амалга ошириш учун «Ягона ойна» операторини яратиш таклиф этилмоқда. Илвор лойихаларни амалга оширишда нафакат илмий-техник йўналишлар, балки самарали инновацион экотизим асосида бошқариладиган турли муассасалар, ташкилотлар, ширкатлар, шунингдек, етарли бўлган бошқарувни мувофиқлаштириш тизимини хам ўз ичига олади.п 
Историография

вопросов музейной

деятельности

библиотек довольно

обширна.

Проблемы

музеесрикации и

мемориальной

деятельности

библиотек получили

своё освещение

во многих трудах

российских

библиотечных и

музейных

специалистов

Целью

предлагаемой

статьи является

определение

социально-

культурных

предпосылок и

фракторов создания

библиотек-музеев;

анализ

типологических

признаков,

особенностей

функционирования

и значения

деятельности

библиотек-музеев

для сохранения и

популяризации

национального

культурного

наследия тельности библиотек и музеев происходит, во многом, благодаря усилению, в первую очередь, мемориальной, кумулятивной и коммуникационной функций данных учреждений. Однако, музей только в отдельных сорерах своей деятельности может выполнять коммуникационную функцию, поскольку предоставляет информацию об объектах хранения, которые сами по себе такую функцию не выполняют (имеются в виду анэпиграфичные предметы, т.е. не имеющие надписей) и без соответствующего восприятия и анализа посетителем, никакой социальной инорормации не несут [19, с. 31].

Историограсрия вопросов музейной деятельности библиотек довольно обширна. Проблемы музеефикации и мемориальной деятельности библиотек получили своё освещение во многих трудах российских библиотечных и музейных специалистов (работы А. Борисовой, В. Викуловой, А. Виноградовой, М. Дворкиной, Ю. Демченко, Л. Киселевой, С. Колосовой, Т. В. Кузнецовой и Т. Я. Куз-нецовой, Т. Майстрович, С. Матлиной, Н. Михалёвой, А. Молодцовой, Т. Опритовой и др.). Научная постановка проблем сущности, идентификации, типологизации и функционирования библиотек-музеев основательно разработана в трудах Ю. Демченко [13-16]. Научный анализ вопросов создания и отдельных аспектов их деятельности, в частности развитие их мемориальных фрункций, осуществлено в трудах ведущего научного сотрудника Российской государственной библиотеки С. Матлиной [20; 21]. В начале XXI в.. в России появляются первые диссертационные работы, обобщающие и систематизирующие теоретический и практический опыт музейной деятельности библиотек (диссертации В. Викуловой (2008), А. Виноградовой (2008), Ю. Демченко (2010)) [9; 11; 14]. В частности, Ю. Демченко построила модель библиотеки-музея по определенным культурологическим признакам, к которым относятся тематическое и смысловое единство библиотечного и музейного частей фронда; общность материальных и нематериальных объектов музеефикации; синтез визуальных, вербальных и семантических средств коммуникации; взаимная адаптация и единство музейных и библиотечных форм и методов работы; активное фрормирование культурного пространства на локальном или региональном уровне [13-16]. Вопросы интеграции библиотек, музеев, архивов, а также музейная деятельность библиотек также исследовались в тру- дах украинских библиотековедов и архивоведов (Н. Волян, С. Кулешова, И. Лосиевского, Н. Розколупы, Н. Синицы, С. Шемаева и др.). К сожалению, в Украине состояние исследования деятельности библиотек-музеев остается ещё на недостаточном уровне: мало исследованы предпосылки возникновения и этапы развития библиотек музеев, недостаточно проанализированы в историческом ракурсе причины обращения библиотек к музейной деятельности, особенности их функционирования, признаки классификационно-типологического распределения и пр. Не проводилось обобщающего анализа деятельности библиотек-музеев по региональному принципу. Остается также неизвестной общая картина развития музейной деятельности библиотек в Украине в целом. Итак, вопросы изучения условий, предпосылок, сущности, типологии, организации, нормативно-правового обеспечения и функционирования библиотек-музеев, а также их мемориальных свойств (музейной составляющей) библиотечного фонда, имеют исключительно важное историко-культурное значение. Целью предлагаемой статьи является определение социально-культурных предпосылок и фракторов создания библиотек-музеев; анализ типологических признаков, особенностей функционирования и значения деятельности библиотек-музеев для сохранения и популяризации национального культурного наследия.

Известно, что библиотеки и музеи осуществляют некоторые общие социальные срункции (культурно-просветительские, научно-информационные, коммуникационные, культурно-образовательные, воспитательные, мемориально-охранные и др.) и выполняют схожие задачи (сбор, обработка, изучение, хранение, демонстрация документов и др.). Вполне логичным является объединение работы двух разных по содержанию фондов (библиотечного и музейного) и организация их функционирования в едином информационном учреждении. Такая интеграция библиотечной и музейной деятельности предполагает проведение в учреждении следующих мероприятий: осуществление исторических научно-исследовательских работ по профилю библиотеки; разработка концепций и программ её развития, а также участие в программах и проектах других учреждений; организация научных конфреренций, симпозиумов, семинаров, практикумов; подготовка к печати научных, научно-популярных, ин- 
фрормационно-справочных, библиографических изданий. Наиболее важными видами работ такого учреждения являются: комплектование и научная организация фонда, от развития которого зависит определение юридического статуса музейного (мемориального) предмета (экспоната), научного и культурного его значения как для науки и культуры, так и для конкретной библиотеки; выявление, изучение и сбор документов из фондов различных библиотек, архивов, музеев и других учреждений (в т.ч. - принятие в дар коллекций и отдельных предметов от юридических и фризических лиц); осуществление учета, хранения, консервации и реставрации предметов-экспонатов; создание электронной базы данных, научно-справочной картотеки и пр.

В библиотеке, как хранилище духовного, исторического и литературного наследия народа, отдельные документы приобретают особую социальную значимость и ценность. Если такие документы непосредственно связаны с теми или иными историческими лицами и событиями, они могут постепенно, по мере исследования и формирования коллекции, превратиться в музейные экспонаты. В свою очередь, использование музейных экспозиций способствует эмоциональному воздействию на посетителей, расширяет социально-коммуникационную функцию библиотек [16]. Если, рядом с популяризацией книги, одним из официально заявленных приоритетов библиотеки будет фрормирование и раскрытие фонда вещей или художественно-образных материалов, меняется статус библиотеки: она принимает на себя исследовательские фрункции и получает музейную специализацию, превращаясь постепенно в библиотеку-музей. Такое явление логически подпадает под определение библиотеки как четырехэлементной системы, предложенной Ю. Столяровым [30]. С одной стороны, библиотека-музей существует для читателей, комплектует фронд тиражируемыми документами, отвечающими читательским запросам, а также обеспечивает материально-техническую базу для сохранения и доступности изданий. C другой - расширяет сфреру действия каждого указанного составного элемента системы и тогда главную роль играют структурные, а не качественные различия. Таким образом, происходит механическое удвоение элементов: фронды - музейные и библиотечные; материально-техническая база - помещения и оборудование - для книг и для экспонатов; библиотекарь - специалист библиотечного и му-

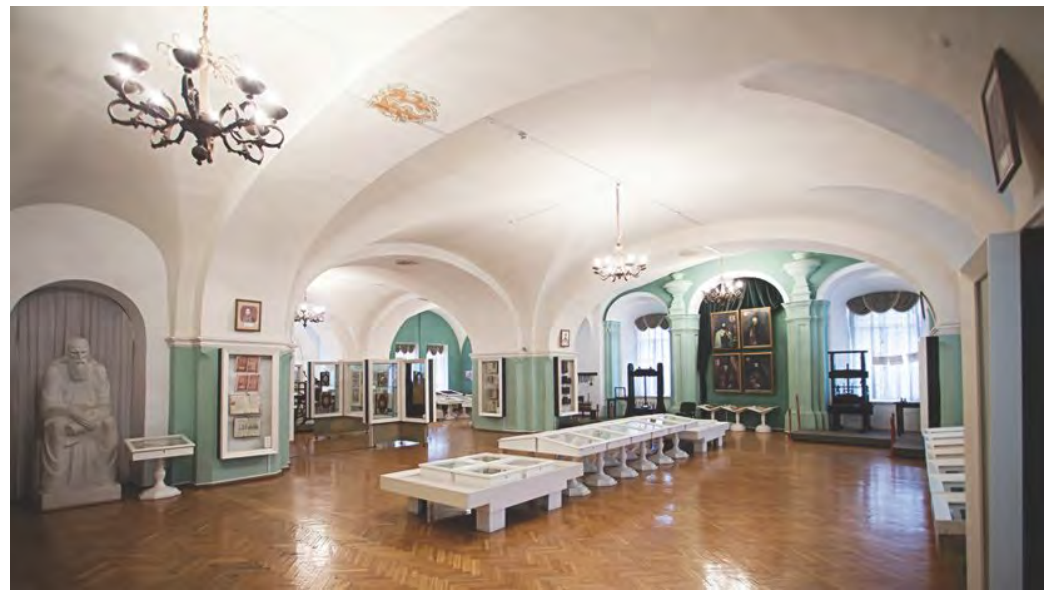

зейного дела; пользователь - читатель и посетитель библиотечного музея. В то же время, экспонаты и книги в библиотеке-музее представляют собой особое культурное единство, дающее новый смысл деятельности учреждения [15, с. 26-27]. Для библиотекмузеев особенно важным является стремление привлечь своих читателей к культурному наследию, стимулировать творческую активность личности, придавая ей для этого новое направление деятельности - участие в создании и развитии библиотеки-музея, как ретранслятора памяти поколений.

Собирая книги, рукописи, предметы быта, национальные костюмы, орудия труда, документы и фотографии прошлых лет, библиотеки-музеи не только стремятся к оригинальности своих коллекций, но и хотят отразить дух и колорит определённой эпохи (в том числе - неповторимость именно своего населенного края и его вклада в общую культуру страны), а также - сохранить воспоминания, традиции, язык как основные составляющие социального опыта и культурной памяти поколений. При этом нематериальная часть культуры становится объектом музеефикации наравне с материальной, что проявляется в таких фрормах деятельности библиотек-музеев как записи рассказов старожилов, возрождения национальных обрядов, местных говоров и т.п. В библиотеке-музее книга или иной вид печатного документа, который относится к экспозиции, является одним из ее системообразующих элементов. Экспонат в библиотеке-музее - это повод для обращения к тексту книги. Отсюда профиль библиотеки-музея должен соответствовать профилю значительной части библиотечного фонда. Поэтому важно формировать библиотечно-музейный фронд по общему плану с единственной четко очерченной идеей и целью. В библиотеке-музее экспонат выступает как символ,
В библиотеке,

как хранилище

духовного,

исторического и

наследия народа,

отдельные

документы

приобретают

особую социальную

значимость и

ценность

Для библиотек-

музеев особенно

важным является

стремление

привлечь своих

читателей

к культурному

наследию,

стимулировать

творческую

активность

личности, придавая

ей для этого новое

направление

деятельности -

и развитии

библиотеки-музея,

как ретранслятора

памяти поколений литературного

участие в создании 
Книга в библиотеке-

музее выступает:

как инструмент

научной обработки

фондов;

как экспонат,

без которого

не обходится

ни одна экспозиция как объект научного

изучения; как

средство

популяризации

знаний,

распространения

библиотечной и музейной культуры

\section{В библиотеке-}

мyзеe

пользователь не просто получает разнообразную

информацию,

но может

удостовериться

в ней с помощью

мемориальных

(музейных)

предметов

которые

представляют

собой

социокультурные

реалии знак текста, иногда даже выполняя дополнительную роль, объясняя, иллюстрируя книгу. Роль посредника между экспонатом и книгой библиотекари нередко берут на себя. При обращении к зрителям, слушателям, участникам того или иного мероприятия, как правило, дают ссылки на издание из фонда библиотеки, где можно больше узнать об эпохе, явлении, событии, которые представляет экспонат. Книга в библиотеке-музее выступает: как инструмент научной обработки фондов; как экспонат, без которого не обходится ни одна экспозиция; как объект научного изучения; как средство популяризации знаний, распространения библиотечной и музейной культуры. Книга или сама является бесценным экспонатом, или помогает раскрывать сущность мемориального (музейного) предмета. Библиотеки, формируя свои фонды, часто являются владельцами уникальных книжных коллекций, уникальных изданий с определенными пометками, записями, экслибрисами, которые имеют исключительную историко-культурную, мемориальную и музейную ценность. Многие из редких и ценных книг являются книжными памятниками и составляют национальное культурное достояние. Такая библиотека становится ведущим партнером музея по сохранению памятников национальной культуры. В библиотеке-музее пользователь не просто получает разнообразную инорормацию, но может удостовериться в ней с помощью мемориальных (музейных) предметов, которые представляют собой социокультурные реалии. Музейные экспозиции в библиотеках представляют собой особые художественно-научные явления, благодаря которым создается возможность установления духовной связи с прошлыми поколениями и вводится в научный оборот новая, достоверная инорормация.

История является стержнем библиотекимузея. Это может быть история человеческого общества, история культуры, но чаще всего - история литературы и искусства, история науки и техники, отраженная в изданиях, рукописях, вещах и других различных документах. Поэтому понятие исторического сознания является одним из главных для деятельности библиотеки-музея, которая представляет собой центр научного документирования региона, где сосредоточены материальные свидетельства (документы) регионального развития общества, культуры, природы, которые несут в себе аутентичную информацию, что имеет решающее научное и культурное значение.

Библиотека-музей - это интегрированное учреждение культуры, которое в равной степени выполняет функции библиотеки и музея. Библиотека-музей, как правило, имеет в своем структурном подразделении библиотечные и музейные отделы, осуществляет комплектование, обработку, систематизацию, хранение и учет документов и предоставляет возможность читателям пользоваться, при определённых ограничениях, книжными и музейными фондами, выполняет просветительские, научные, развлекательные программы с использованием особо редких и ценных инорормационно-документальных и мемориальных ресурсов. У некоторых библиотековедов термины «библиотечно-музейный центр», «библиотечно-музейное учреждение» используются как синонимы к понятию «библиотека-музей» [7-10]. Библиотековед А. Молодцова считает, что библиотека-музей - это комплексное учреждение культуры, где книга работает рядом с экспонатом, но выполняет ведущую социальную и инфрормационную роль [22, с. 16]. По аналогии деятельности библиотек и музеев, библиотеку-музей можно определить как учреждение, выполняющее функции и библиотеки, и музея [26, с. 24]. Основным функциональным отличием библиотеки-музея, также как любого музея при библиотеках (музейной библиотеки), являются определённые ограничения в доступности документов (оставляя их открытыми только для научной работы) и широкое публичное экспонирование. Таким образом, библиотека-музей - это многофрункциональное культурно-просветительское и научное некоммерческое учреждение, которое формирует и сохраняет библиотечные и музейные фонды (документы), проводит инорормационную, просветительскую и научноисследовательскую работу для формирования локальной культурной микросреды. Библиотека-музей поддерживается государством или владельцем, или существует на общественных началах с целью обеспечения хранения, изучения и публичного представления музейных документов и библиотечных коллекций. Библиотека-музей как профессиональное объединение усилий многих специалистов (в большинстве, библиотечных и музейных), меценатов, любителей и энтузиастов музейного дела, создается в направлении развития и совершенствования музейной деятельности библиотеки с целью приближения фондов уникальных документов к пользо- 
вателям. Как одна из разновидностей библиотек, библиотека-музей - это учреждение, где создается особая коммуникационная среда, связь между прошлым и настоящим, где наглядными средствами по определенной тематике (или по другим признакам) дается информация об историческом развитии определенного социального явления, связанного с культурной, научной и производственной деятельностью региона с целью сохранения документных и книжных памятников, изучения истории, популяризации культурного наследия народа. Важными задачами библиотеки-музея являются: раскрытие вклада библиотеки в научно-образовательное и культурное поступательное движение края; привлечение внимания к своей деятельности новых пользователей и потенциальных партнеров; повышение ее статуса в современном социуме; организация на базе публичных библиотек музейных экспозиций, объектов исторического, культурного, природного достояния края путем аккумуляции и интеграции региональных информационно-документальных и мемориальных ресурсов; создание необходимых условий для их хранения, рационального использования и пропаганды среди местных жителей. Как отмечает исследовательница С. Матлина, происходит синкретическое взаимопроникновение библиотечных и музейных орорм, на основе чего в публичных библиотеках по инициативе библиотекарей или энтузиастов и владельцев раритетов создается новая модель библиотеки (библиотека-музей) на базе историко-краеведческих, историко-литературных, историко-этнографрических и других постоянных экспозиций [21, с. 3-4]. Профриль большинства библиотек-музеев зависит от характера и содержания музейной экспозиции, которая предопределяет и основные разновидности самих музеев.

С Матлина выделяет три основных разно-видности библиотек-музеев: историкоэтнографические и историко-краеведческие библиотеки-музеи; мемориальные (в том числе, литературные) библиотеки-музеи и библиотеки-музеи народного искусства. Сюда же, как отдельный вид, можно добавить библиотеки-музеи истории библиотеки или библиотечного дела.

Однако, классификация библиотекмузеев может происходить по раз-личным признакам, например по типу хране-ния документов (коллекционные, ансамбле-вые и др.), по статусу (центральные, район-ные, филиалы библиотеки-музея и др.) и пр. Библиотеки-музеи можно определять по сложившемуся профрилю, например историческому, этнографическому, литературному, мемориальному, естественно-научному, сельскохозяйственному, тематическому и т.п. (вообще, существует более 40 видов музеев). В библиотечной практике количественное превосходство имеют историко-краеведческие и литературно-мемориальные музеи. Успех работы библиотеки-музея заключается в том, что здесь экспонаты работают рядом с книгой, усиливая ее инфрормационную составляющую, и в целом оказывая более сильное эмоциональное и культурное воздействие на пользователей.

Библиотеки-музеи относятся к тому типу библиотек, в которых музейная деятельность равнозначна библиотечной и осуществляется на постоянной основе и требует для своего осуществления значительных трудовых и материальных затрат, соответствующего отражения в фрормулировке целей и задач учреждения. Вообще, соотношение музейной и библиотечной деятельности связано с периодичностью обращения библиотеки к фрормам и методам работы своего музея: равнозначность двух видов деятельности предполагает, что осуществляются они на постоянной основе. По мнению Ю. Демченко, от характера музейной работы библиотеки, особенностей функционирования ее музейного отдела, библиотеки делятся на библиотеки-музеи, музеи-библиотеки, библиотеки с библиотечным музеем, мини-музей в библиотеке и т.д. [14, с. 82-89]. Исследовательница отмечает, что музей-библиотека - это библиотека, которая углубленно занимается гуманитарными исследованиями, воплощает в этом направлении свои достижения в виде научных и научно-популярных текстов (публикаций) и в виде определенных предметов (в том числе музейных), пытается наилучшим образом отвечать на широкие инорормационные и культурные запросы пользователей, а также на узкоспециальные запросы по профилю своей научной деятельности [14, с. 90]. Мини-музей в библиотеке - это небольшая по объему музейная коллекция (или постоянная выставочная музейная экспозиция, уголок, комната) в библиотеке, которая, как правило, официально и документально не офрормлена должным образом. В большинстве случаев, мини-музей в библиотеке - это современное наименование краеведческого или этнографрического уголка или комнаты в библиотеке.
Важными

задачами

библиотеки-музея

являются:

раскрытие вклада библиотеки

в научно-

образовательное

и культурное

поступательное

движение края;

привлечение

внимания к своей

деятельности

новых

пользователей и

потенциальных

партнеров

Исследовательниц

а отмечает,

что музей-

библиотека - это

библиотека,

которая углубленно

занимается

гуманитарными

исследованиями,

воплощает в этом

направлении свои

достижения в виде

научных и научно-

популярных текстов

(публикаций) и

в виде

определенных

предметов 
Все библиотеки-

музеи выполняют

определенные

специализированн

ые мемориальные

функции по

отношению

к конкретным

френоменам

прошлого, одной из

распространенных

фрорм реализации

которых является

создание

в библиотеках

музейных

экспозиций

Библиотека-музей это относительно новое направление

в развитии

библиотечного

обслуживания

населения, новый

подход

к краеведческой деятельности,

который

заключается

в проведении

самостоятельного

краеведческого

поиска
Часто мини-музеем называют небольшую по количеству экспонатов и занимаемой площади музейную экспозицию в библиотеке, которая способствует пропаганде книг и чтения, организации досуга читателей [14, с. 87-88].

Все библиотеки-музеи выполняют определенные специализированные мемориальные функции по отношению к конкретным френоменам прошлого, одной из распространенных фрорм реализации которых является создание в библиотеках музейных экспозиций. Музейные экспозиции, в большинстве случаев, делятся на три группы: первая - музейные экспозиции, которые существуют обособленно в библиотеке-музее как вторичный элемент системы; вторая группа - музейные экспозиции, представляющие собой часть мемориального комплекса, который состоит из нескольких обособленных элементов, связанных единой тематикой (например, те, что принадлежали одной эпохе, одной исторической личности и др.); третья группа - музейные экспозиции, которые являются частью мемориального библиотечного подфонда, как совокупности некоторой части библиотечного фронда и других элементов, объединенных не только общей тематикой, но и справочно-библиографрическим аппаратом. Такие своеобразные библиотеки с музейными экспозициями, куда люди несут редкие и ценные предметы культуры, иногда - музейные экспонаты, отражают личную жизнь и определённую историю повседневности, которая у нас недостаточно исследована. При этом библиотекари активно помогают местным жителям изучать семейные родословные, составлять генеалогические деревья, личные архивы и т.п. Часто инициатива преобразования обычной публичной библиотеки в библиотеку-музей принадлежит именно библиотечным сотрудникам, которые пишут запросы в архивы, изучают биографии представителей местной интеллигенции, осуществляют разнообразную научно-поисковую работу [26, с. 24]. Логика исследовательской деятельности наиболее развитых библиотек музеев приводит к превращению их в мемориальные библиотеки. По сути, любая библиотека, не говоря уже о библиотеке-музее, выполняет мемориальную функцию, собирая, сохраняя и распространяя культурную память [20]. Библиотека-музей - это относительно новое направление в развитии библиотечного обслуживания населения, новый подход к краеведческой деятельности, который заключается в проведении самостоятельного краеведческого поиска, собирания и сохранения вещей и нетрадиционных для библиотек материалов. Объединение библиотеки и музея в одном заведении не только возможно, но и особенно необходимо в сельской местности и отдаленных от центра местах, где библиотека-музей не роскошь, а способ выживания и фрорма развития культурной среды.

Приведем краткую характеристику основных видов библиотек-музеев. Так, мемориальная библиотека-музей освещает биографрию известных и выдающихся личностей и семей на фроне раскрытия различных историко-культурных явлений или выявляет важные исторические события либо исторические места, связанные с развитием хозяйства, культуры края, а также фрактов, касающихся библиотеки или фрормирования ее библиотечного и музейного фонда. Близкими к вышеназванной разновидности являются историко-краеведческие и историко-этнографические библиотеки-музеи, которые на примерах письменных документов и предметов культуры и быта также раскрывают определенные исторические фракты, события и периоды развития материальной и духовной культуры края. Краеведческий фронд таких библиотек-музеев (книги, периодика, электронные издания, кино-, фрото-, аудио-документы, брошюры, буклеты и др.), как правило, выделяют из основного фонда и располагают на отдельных полках и постепенно пополняют соответствующими вещами и документами. Постепенно формируют краеведческие тематические папки, исторические альбомы, содержащие оригиналы или копии документов, публикации из газет и журналов, письма, воспоминания, мемуары, дарственные грамоты, другие материалы из семейных архивов местных жителей. Популяризации и распространению краеведческих знаний способствуют подготовленные библиотекоймузеем краеведческие литературные очерки, библиографрические указатели (персональные и тематические), краеведческие календари, буклеты о музейных экспозициях и т.п.

Некоторые библиотеки-музеи имеют культурно-художественное направление профиля экспозиции и фрондов, которые раскрывают разные жанры художественного искусства, преимущественно - художественных произведений мастеров определенного края (главным образом - произведений народного искусства). По большей части, основу музей- 
ных коллекций таких библиотек-музеев составляют оригинальные памятники истории общества и природы; предметы материальной и духовной культуры края, которые представлены образцами декоративно-прикладного искусства; образцами продукции местных предприятий, представляющими художественную ценность; интересными фротографиями; собраниями оригиналов произведений искусства или их копиями; вещами личного и профессионального пользования известных мастеров и художников края и пр. Фонд библиотеки-музея фрормируется в соответствии с видом библиотеки, профиля хранения книг и других документов, согласно информационным потребностям населения, исторических, экономических, культурных и других особенностей региона, как упорядоченное собрание изданий, рукописей, изобразительных материалов и музейных предметов путем их приобретения, безвозмездной передачи от учреждений, организаций, граждан и другими способами, не противоречащими действующему законодательству. Особенно ценные, редкие документы и коллекции должны быть включены в Государственный реестр национального культурного достояния страны. В случае, если библиотека не обеспечивает необходимых условий для их хранения и использования, они могут быть переданы другим библиотекам или музейным учреждениям в соответствии с законодательством.

Создание и функционирование библиотек-музеев обусловлены: развитием научноисследовательской работы библиотеки, особенно - с редкими и ценными изданиями; использованием методов музейной работы в создании мемориальных книжных выставок, музейных экспозиций и мемориальных уголков; изучением истории создания библиотеки и формирования её библиотечных коллекций как объекта исследовательской и музейной деятельности; систематическим ведением историко-краеведческой работы и фрормированием фонда краеведческой литературы; организацией выездных экспозиций вместе с музейными учреждениями; проведением экскурсий и различных фоорм культурно-массовой работы [24, с. 57-58]. Соответственно, фракторами, которые могут побудить создание библиотеки-музея могут быть:

- активизация краеведческой работы; поиск новых фрорм деятельности при уменьшении количества читателей и фринансирования библиотеки;
- организация выставок и музейных экспозиций в библиотеке, что вполне совместимо с её мемориальной и просветительской функциями;

- наличие значительного количества музейных предметов, подаренных в библиотеку (общественные и частные источники комплектования музейной экспозиции);

- личная заинтересованность сотрудников библиотеки иметь «собственное лицо», выделить в историко-культурной среде своё место, прославить свой город или село либо своих земляков;

- общедоступность и бесплатность инфрормационных и демонстративных услуг;

- удовлетворение разноплановых культурных потребностей и мотиваций.

Инициатива создания музейных экспозиций, как правило, исходит от: сотрудников библиотеки; родственников писателя, ученого или иного выдающегося деятеля; жителей района города или села, общественных или церковных деятелей; краеведов; деятелей науки, образования, культуры; коллекционеров, библиосилов и др. Так, например, заведующая библиотеки с. Жовтень Сахновщинской ЦБС Харьковской области Т. Побидынская поставила себе целью в 2005 г.. создать библиотеку-музей - собрать, офрормить, сохранить и предоставить своим читателям источники и инорормацию о родном крае, о людях своего села. При офрормлении и расстановке исторических экспонатов и литературы она сорормировала следующие основные направления (разделы) представления материалов: исторический; народоведческий; географрический; экологический; литературное краеведение; выдающиеся люди родного края. Сейчас указанная библиотека-музей занимает две просторные комнаты со стендами и выставками. Наряду с музейными экспонатами, которые были собраны Т. Побидынскою и активом библиотеки, оформлены также книжные выставки. В библиотеке систематически пополняется архив воспоминаний старожилов. Заведующая библиотекимузея проводит экскурсии-беседы, комментируя историко-краеведческие, литературные и этнограсрические материалы экспозиций [25]. Это доказывает тот фракт, что только тогда, когда сами сотрудники будут увлечены идеей создания музея в своей библиотеке и добровольно возьмут на себя дополнительную нагрузку, смогут привлечь к работе по организации музея местную администрацию, читателей и жителей определённой местнос-
Фонд

библиотеки-музея

фрормируется

в соответствии

с видом

библиотеки, профиля

хранения книг и других документов, согласно

инорормационным потребностям

населения

\section{Создание и}

функционирование библиотек-музеев обусловлены: развитием научноисследовательской работы

библиотеки, особенно с редкими и ценными изданиями 
ти, - только в этом случае будет возможным организовать музей в библиотеке (поскольку создание музеев в библиотеках не предусмотрено типовым штатным расписанием). К примеру, в постановлении городского совета г. Красный Лиман Донецкой области от 19.03.2014 г. «О работе инновационных моделей библиотек централизованной библиотечной системы отдела культуры и туризма Краснолиманского городского совета»указано, что несмотря на трудные фринансовые условия, недостаточное поступление новой литературы, библиотечные сотрудники продолжают поиск интересных новых фрорм работы. В частности, было создано 11 инновационных типов библиотек: библиотека-музей, библиотека-горница, библиотека-дом природы и др. Всего в Краснолиманском районе действует 23 библиотеки (центральная городская библиотека для взрослых, центральная детская библиотека, девять поселковых и 12 сельских библиотек) [1]

Список использованной литературы:

1) «Про роботу інноваційних моделей бібліотек для громади иентралізованої бібліотечної системи відділу культури i туризму Краснолиманської міської ради» // Красный Лиман: Официальный сайт Краснолиманского городского совета. - URL: http://krliman.gov.ua/documents/19-03-2014/20140401-12

2) Библиотечная энииклопедия / Рос. гос. б-ка.; сост.: Е. И. Ратникова, Л. Н. Уланова. - Москва: Пашков дом, 2007. - 1300 с.

3) Бібліотека - регіональний иентр інформації: (з досвіду роботи бібліотек-музеїв) / Упр. культури, туризму і курортів Хмельнии. облдержадмін.; Хмельнии. ОУНБ ім. М. Островського / Уклад. Н. М. Синиця; Ю. М. Гой; Ю. А. Стецюк. - Хмельницький, 2008. - 16 c.

4) Бібліотека року (за результатами обласного огляду-конкурсу сільських бібліотек): з досвіду роботи / Упр. культури, на- иіональностей та релігій Хмельнии. облдержадмін.; Хмельнии. ОУНБ ім. М. Островського. - Хмельнииький, 2013. - 24 с.

5) Бібліотека-музей: Методичні рекомендаиії / Упр. культури, туризму і курортів Деражнян. Райдержадмін.; Деражнян. ЦРБ; Уклад. Ю. А. Стеиюк; В. К. Куиюк; Т. В. Матвієнко. - Деражня, 2009. - 16 с.; см. также: Методичні рекомендації щодо створення на базі публічних бібліотек поліфункціональних установ бібліотек-музеїв / Упр. культури, туризму і курортів Хмельнии. облдержадмін.; Уклад.: Г.Й. Фурманчук, К. А. Чабан. - Хмельницький, 2009. -32 c.

6) Борисова Е. И. Нормативно-правовое регулирование мемориальной деятельности публичных библиотек: за и против / E. И. Борисова //Библиотечное дело. 2010. - № 21 (135). - C. 20-24

7) Викулова В. П. Дом на Никитском: история, которая живет / В. П. Викулова // Библиотека. - 2008. - № 9. - С. 34-41

8) Викулова В. П. Исследование мемориальной функции публичной библиотеки / В.П. Викулова // Библиотековедение. 2008. - № 8. - C. 32-36

9) Викулова В. П. Мемориальная деятельность публичной библиотеки: организационно-управленческая кониепция: Дис. канд. пед. наук: 05. 25. 03 / В. П. Викулова. М., 2008. - 272 с.; см.. также: Викулова В. П. Мемориальная деятельность библиотеки: организационно-управленческая кониепиия: Монография / Департамент культуры г. Москвы, Центр, гор. б-ка - мемор. иентр «Дом Гоголя»; науч. ред. проф. В. К. Клюев ; авт. вступ. ст. М. Д. Афанасьев. - Москва: «Издательство ФАИР», 2009. -320 C.

10) Викулова В. П. Музеи в библиотеках, библиотеки в музеях /В. П. Викулова // Информ. бюл. РБА. - Санкт-Петербург, 2004. - № 9. - C. 27-29

11) Виноградова Е. Б. Мемориальные библиотеки: классификационный и типологический анализ: Дис. канд. пед. наук: 05. 25. 03 / Е. Б. Виноградова. - Москва, 2008. 269 c.

Виктор Соколов - Ярослав Мудрий номидаги Украина Миллий кутубхонаси бош мутахассиси, тарих фанлари номзоди, доцент.

Мақолада кутубхона-музейларнинг мухим жихатлари ва улар фаолиятининг уцзига хос хусусиятлари, шунингдек кутубхона музейида олиб борилаётган илмий тадқиқотлар ривожланишига хамда миллий маданий меросни сақлаш ва уларни оммалаштириш хақида суиз борган. Кутубхона-музейлар мемориал ёдгорлик ва маданий-магрифий марказлар фаолиятини тахлил этиш имкониятлари мавжудлиги хақида хам айтилган. Кутубхона ва музейларни умумий ижтимоий фаолияти ёритиб берилган. Кўпгина музейларни шаклланиш босқичида кутубхона фаолияти билан бовлик томонлари мутахассисларнинг қарашларида ханузгача бирдамлик мавжуд эмаслиги айтиб ўтилган. Мақоланинг мақсади кутубхона-музей яратилишида, ижтимоий маданий омилларни аниқлаш х,амда типологик методлар асосида кутубхона-музейлар фаолиятини тахлил этишдан иборат. 
Роскошный альбом

- полиграфический шедевр «Описание

Священного

Коронования

их императорских величеств государя

императора

Александра

Третьего и

государыни

императриць

Марии

Феодоровны всея

России» (1883)

Фонд отдела

редких книг имеет

определенное

краеведческое

направление.

Этот «местный

характер»

особенно ценен

для людей,

интересующихся

историей

мордовского края политическим, социальным, историческим, естественным и медицинским наукам, а также художественная литература: в том числе академические, научные дешевые и популярные издания для народа, книги по литературоведению, а также издания для детского чтения.

Особой гордостью фонда являются издания, вышедшие еще при жизни авторов: «Российская грамматика» М.В.Ломоносова (1757), на титульном листе которой сохранилась запись прежнего владельца - Архимандрита Соловецкого монастыря Варсонофия (в миру - Василий Щеныков), сделанная в ноябре 1759 года, трагедия «Феминист и Иеронима» В. Майкова (1775), «Сочинения» Г. Р. Державина (1808), поэмы «Эрпели и Чир-Юрт» А.И. Полежаева (1838), «Поэмы и повести» А. С. Пушкина (1835) с экслибрисом «Из книг Владимира Николаевича Лялина», первый номер журнала «Современник» (1836).

Среди изданий, привлекающих наибольшее внимание, как правило, выделяются книги необычного размера - книги-гиганты и мини-издания. Роскошный альбом - полиграфический шедевр «๐писание Священного Коронования их императорских величеств государя императора Александра Третьего и государыни императрицы Марии Феодоровны всея России» (1883). Книга офрормлена с использованием лучших тканей и переплетных материалов, великолепно иллюстрирована лучшими русскими художниками своего времени, среди которых есть и наш земляк известный мордовский художник Иван Кузьмич Макаров. Данное издание поражает своими размерами: 65×49 см. Это самая большая книга в фрондах Национальной библиотеки им. А. С. Пушкина РМ.

Самые маленькие книги - это отрывки из произведений «Медный всадник», «У лукоморья», «Памятник», «Анчар», «19 октября» размером всего 15х20 мм, изданные в Санкт-Петербурге в издательстве «Шпора» в 2007 году. Взяв эти книги в руки, пролистав их, появляется желание не только изучить их как произведение полиграсрического и переплетного искусства, но ещё раз перечитать знакомые с детствапроизведения.

Фонд отдела редких книг имеет определенное краеведческое направление. Этот «местный характер» особенно ценен для людей, интересующихся историей мордовского края. В фронде бережно хранятся «Господань Минек Иисусань Христань Святой Евангелья. Стормадозь эрзянь келсе» («Господа на- шего Иисуса Христа Святое Евангелие от Луки») на эрзянском языке, вышедшее в Петербурге в типографрии Николая Греча в 1821 году, первая прижизненная «Мордовская грамматика, составленная на наречии мордвымокши» Павла Петровича Орнатова (1838). Украшением фронда является книга Акселя Олая Гейкеля «Одежда и орнамент мордвы». Она была издана в Хельсинки в 1899 году. В ней представлены рисунки и вышивки мордовских (мокшанского и эрзянского) костюмов; выявлены и рассмотрены различия эрзянской и мокшанской одежды. Не менее интересны издания, вышедшие в городе Саранске в типографии братьев Сыромятниковых первых печатников города - «Каталог Саранской Городской Публичной библиотеки» (1898г.) и «С юными паломниками в Пайгармский монастырь» (1909г.)

Отдел располагает единичными экземплярами с цензурным разрешением, изданиями военных лет, книжными собраниями библиотек частных и коллективных владельцев. Уникальность определяется особенностями самих книг. Среди них такие неповторимые признаки, делающие экземпляры особенными, как: экслибрисы, суперэскслибрисы, дарственные надписи, автографы, владельческие и читательские пометы. Перечислить все признаки, которые делают книги свидетелем истории и помогают восстановить реальную картину связанных с нею событий и фрактов, в рамках небольшой статьи, пожалуй, невозможно. Скажем лишь, что в фонде хранятся издания с экслибрисами известных лиц дореволюционной России и нового времени: Императора Александра II Николаевича (Романова); представителей знаменитой купеческой династии Гарелиных; критика, историка западноевропейской и русской литературы Петра Семеновича Когана; князя, темниковского уездного предводителя дворянства (1872-1884) Петра Васильевича Ищеева; общественно-политического деятеля, журналиста, писателя Игоря Платоновича Демидова; Городского главы, гласного городской Думы, присяжного и частного поверенного окружного и уездного судов, председателя попечительства церкви Александра Невского Андрея Андреевича Любомудрова; русского фрилософра, мыслителя, культуролога, теоретика европейской культуры и искусства Михаила Михайловича Бахтина и др.

На протяжении нескольких лет отделом проводится нелегкая, ёмкая, но безумно ин- 
тересная научно-исследовательская работа с самой востребованной на сегодняшний день коллекцией «Личная библиотека Михаила Михайловича Бахтина» - русского философра, культуролога, теоретика европейской культуры и искусства, более 25 лет прожившего в городе Саранске. Только за последние два года, редкий фонд Национальной библиотеки, с целью ознакомления с библиотекой М. М. Бахтина, посетили более 30 учёных из Великобритании, Испании, Бразилии, Японии и др.

Помимо книжного фонда библиотека обладает периодическими изданиями второй половины XIX - начала XX века. Это собрание универсальное по тематике и насчитывает более 3 тыс. экземпляров. Здесь представлены дореволюционные журналы: «Вестник Европы», «Исторический вестник», «Русская мысль», «Русская старина», «Мир божий», «Образование» и др.

Глубоко понимая непреходящую ценность дошедших до нас уникальных памятников истории и культуры, мы стараемся через раскрытие редкого фронда и книжных коллекций отдела самопрезентовать Национальную библиотеку в виртуальном пространстве, применяя электронную и традиционную фрормы работы с инорормацией. Просветительскую миссию выполняют созданные отделом группы в социальных сетях: «Книжные сокровища Пушкинки» https://ok.ru/knizhnyes; «Отдел редких книг и работы с книжными памятниками» https://vk.com/orkrm; «Отдел редких книг и работы с книжными памятниками» https://www.facebook.com/groups. Приоритетным направлением работы в группе является популяризация уникальных памятников культуры, в частности здесь рассказывается об отдельных уникальных экземплярах раритетных изданий или освещаются целые книжные собрания(коллекции) из редкого фонда библиотеки. Представленные нами подлинные рукописные, печатные документы и уни- кальные книжные издания привлекают большинство участников и играют большую роль в фрормировании интереса и уважения к отечественной и зарубежной истории и культуpe.

С 2018 года при отделе открыт Клуб любителей редкой книги “Старина». Он объединяет всех, кто ценит и любит старинную книгу, кому дороги традиции российского книгоиздания, кого волнуют проблемы чтения и восприятия книг, переживших века. На сегодняшний день состоялось уже 12 заседаний клуба.

Работа с редкими книгами - это осязаемое прикосновение к прошлому, к уходящему в глубину веков началу начал. Бережно сохраняя эти уникальные издания, мы помогаем сделать ощутимой и наглядной неразрывную связь поколений.

\section{Список использованных источников:}

1. Книжные памятники - коллекиии редкого фонда Национальной библиотеки им. А.С. Пушкина Республики Мордовия / М-во культуры и туризма РМ, Нац. б-ка им. А.С. Пушкина РМ, Отдел редких книг и работы с кн. памятниками; сост. Н.Н. Земкова. - Саранск: [б. и.], 2015.32 с.

2. Земкова Н.Н. История и развитие отдела редких книг и работы с книжными памятниками / Н.Н. Земкова // Библиотечное краеведение Мордовии: вып. 22 / сост. С.Н. Архипова.-Саранск: [б. и.], 2014. С. 33-37.

3. Земкова Н.Н. Коллекция книг первых лет существования Саранской Городской народной бесплатной библиотеки -читальни //История библиотек как отражение историко-культурного развития Республики Мордовия: материалы IV Краеведческих чтений / Н.Н. Земкова / М-во культуры и туризма РМ, Нац. б-ка им. А. С. Пушкина РМ; [сост. С.Н. Архипова; ред-кол.: А.И. Степанов и др.]. - Саранск: [б.и.], 2014. С. 102-105.

4. Земкова Н.Н. Редкий - не значит недоступный. Раритеты в соцсетях / Н.Н. Земкова //Библиотека. - 2020. - №8. - С.13-14
Помимо книжного фонда библиотека обладает периодическими изданиями второй половины XIX начала XX века. Это собрание универсальное по тематике и насчитывает более 3 тыс. экземпляров

\section{С 2018 года}

при отделе открыт Клуб любителей редкой книги «Старина». Он объединяет всех, кто ценит и любит старинную книгу, кому дороги традиции российского книго-издания

Наталья Земкова - А.С. Пушкин номидаги Мордовия Миллий кутубхонасининг қўлёзма ва ноёб ёдгорликлар бўлими бошливи.

Муаллиф мақолада Мордовия Республикасидаги 120 йиллик тарихга эга йирик кутубхонанинг қуллёзма ва нодир китоблари хақиида ўз фикрларини баён этган. Нодир китоблар фондида XVIII аср охири ва XX асрнинг бошларига оид босма нашрлар сақланаётган бўлиб, уларнинг аксарияти ягона нусхада эканлиги билдирилган. Хозирги кунда кўлёзма ва ноёб ёдгорликлар бўлимида 14000 мингдан зиёд махаллий ва хорижий нашрлар сақланмоқда. Шунингдек фонддан алохида кийматга эга бўлган бадиий нашрлар хамда китоб нашр этиш тарихининг айрим даврларини акс эттирган матбаа ижодининг дурдоналари х,ам уррин олган. Бунга 1957 йилда нашр этилган М.В.Ломоносовнинг дастхати туширилган «Рус грамматикаси» китобини мисол сифатида айтиб ўтган. 


\section{МОБИЛЬНОЕ БИБЛИОТЕЧНОЕ ОБСЛУЖИВАНИЕ НА ПРИМЕРЕ НОВОСИБИРСКОЙ ОБЛАСТНОЙ ДЕТСКОЙ БИБЛИОТЕКИ \\ ИМ. А. М. ГОРЬКОГО}

do)

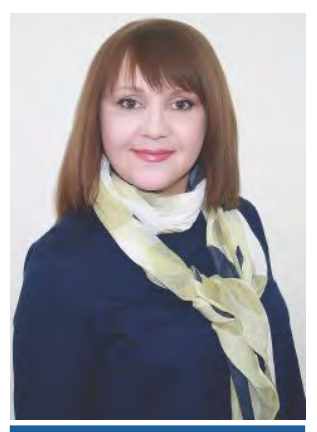

Ольга Костина, директор

государственного

бюджетного

учреждения

культуры

Новосибирской

области

Областная детская

библиотека

им. А. М. Горького

Областная детская

библиотека

им. А. М. Горького уже не первый год организует передвижной библиотечный

пункт на

железнодорожном вокзале «Новоси-

бирск-главный»,

в рамках акции

«Книга в дорогу»
$\mathrm{M}$ обильность-этот распрострнённый современный термин употребляется во многих сорерах жизнедеятельности человека. Применительно к библиотеке, в узком смысле, обозначает транспортное средство, перевозящее документы библиотечного фронда - хорошо знакомые нам библиобусы. Более широко понятие «мобильная библиотека» трактуется как передвижная библиотечная служба. Этот вид обслуживания позволяет библиотеке прокладывать маршруты в те места, где книги будут наиболее востребованы. Прежде всего - места большого скопления людей и зоны культурного отдыха.

Государственное бюджетное учреждение культуры Новосибирской области «Областная детская библиотека им. А. М. Горького»крупная центральная библиотека региона, методический центр для библиотек, обсуживающих детей в Новосибирской области. Библиотека, основанная в 1956 году, сегодня обслуживает около 18 тысяч читателей в год, имеет в фонде 223 тысячи экземпляров библиотечных документов.

В числе прочих библиотек Российской Федерации мы выбрали такой вектор развития, который позволяет нашей библиотеке быть востребованной своими целевыми группами за счет многофрункциональности и разнообразия библиотечных сервисов. Предоставление услуг вне стационара, на наш взгляд, является одним из эфрорективных способов популяризации и предоставления библиотечных ресурсов, позиционирования детской библиотеки, как доступного учреждения культуры, где можно не только взять книги на дом, но и с пользой провести свой досуг.

Областная детская библиотека им. А. М. Горького уже не первый год организует передвижной библиотечный пункт на железнодорожном вокзале «Новосибирск-главный», в

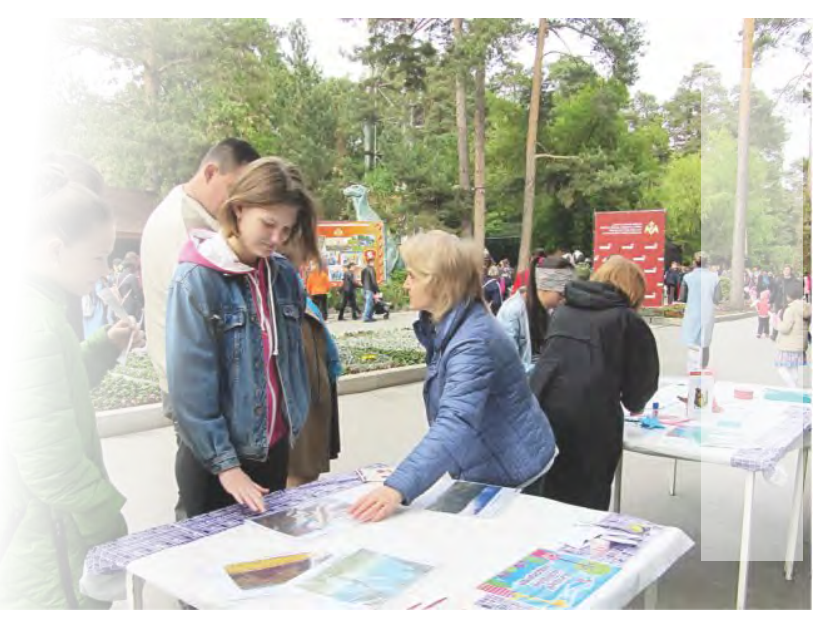

рамках акции «Книга в дорогу». Руководство ж/д вокзала поддержало инициативу библиотеки, оказав помощь в организации пункта обслуживания, обеспечив необходимой мебелью: стеллажом для книг, столом и стульями. Библиотека, предназначенная в дорогу, формируется в основном из списанной из библиотечного фонда беллетристики для взрослых и детей, сказок и периодических изданий. Подобная литература пользуется спросом во время путешествий, поскольку лёгкое увлекательное чтение наилучшим образом помогает скоротать время в пути. Отправляя книгу в дорогу, библиотека решает как минимум три задачи: приобщает людей к чтению, скрашивает однообразие железнодорожного маршрута дальнего следования и продлевает жизнь книге и журналам ещё на какое-то время. Есть у этой акции одна особенность: до начала посадки, прежде чем пассажиры разойдутся по своим вагонам, на площадке мобильной библиотеки дети могут интересно провести время, поучаствовав в литературных играх и викторинах, скрасив, таким образом, свой дорожный досуг и, конечно же, улучшив настроение. Подобное культурное мероприятие на железнодорожном вокзале «Новосибирск-главный», безусловно, делает его облик ещё более привлекательным для гостей и жителей нашего города.

«...библиотечная служба, не стоящая на месте...» - такое определение мобильной библиотеке даётся в Руководстве по мобильным библиотекам ИФЛА. Покидая собственные стены, библиотека расширяет возможности доступа к своим ресурсам. За пределами своей площадки бывает довольно проблематично осуществлять полноценное обслуживание населения. Связано это в первую очередь с тем, что книги из фондов выдаются на руки только читателям, офрормленным в 
библиотеку по всем правилам. Тем не менее, в мобильных условиях привлечь внимание горожан к конкретным книгам и библиотеке, вполне возможно. Именно с этой целью Новосибирская детская библиотека им.А.М. Горького в 2016 году возродила свою давнюю традицию - выходить в парк культуры и отдыха. Для организации передвижного пункта библиотечного обслуживания нами был выбран парк культуры и отдыха «Берёзовая роща». Заключив договор с руководством парка на проведение культурно-досуговых мероприятий, библиотека в определённый день недели в летний период организует площадку для посетителей, чтобы познакомить с детской литературой, рассказать о библиотеке, приобщить к чтению через полюбившиеся юным читателям литературные игры и викторины. Подобные мероприятия в местах отдыха горожан вызывают живой интерес и желание поучаствовать не только у детей, но и у взрослых.

«В гости к куклам!» - под таким девизом детская библиотека им. А. М. Горького порядка 10 лет организует мобильную площадку в Новосибирском областном театре кукол. Учитывая возрастной контингент зрителей, организаторская роль в работе данной площадки закреплена за отделом обслуживания дошкольников и младших школьников. Задача библиотекарей заключается в привлечении внимания детей к книгам перед началом спектакля и во время антракта. С этой целью в фройе оформляется тематическая книжная выставка, раскладываются демонстрационные материалы, родителям предлагается информационная продукция библиотеки. Примечательностью библиотечного пункта является игровой компонент, состоящий из литературных игр и викторин, разработанных по специальной методике с учётом возрастных особенностей детей до пяти лет.

Новосибирск - крупный город с населением свыше полутора миллионов человек. Как и в любом мегаполисе, в нашем городе насыщенная культурная жизнь, которую поддерживают не только театры, музеи, концертные организации, но и библиотеки, а их в городе 76. Не стала исключением областная детская библиотека. На протяжении последних трёх лет мы организовывали мобильную площадку в Новосибирском зоопарке в День защиты детей 1 июня. Традиционно в этот день на территории зоопарка проводится Праздник детства. Специалисты нашей библиотеки готовят для юных горожан и их роди-

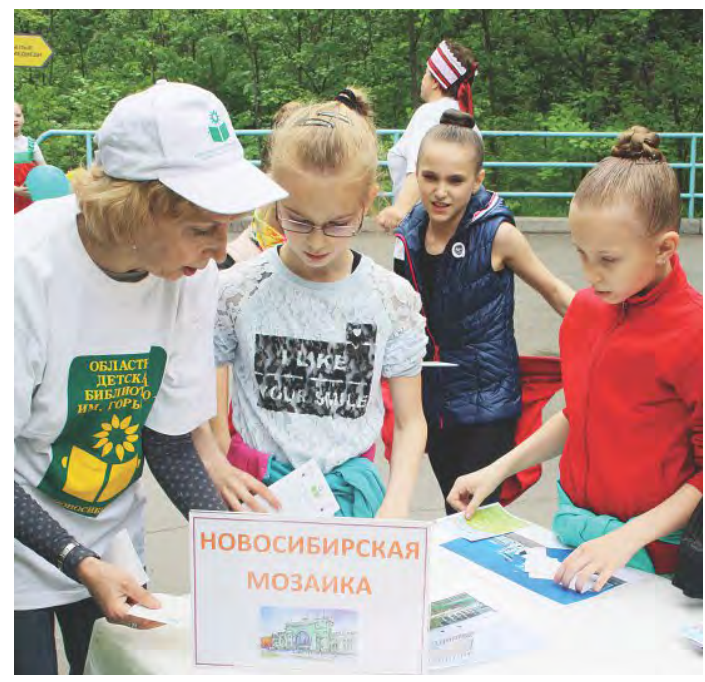

телей программу краеведческой тематики, позволяющую проверить свои знания по истории и культуре города и Новосибирской области. А для подсказки на помощь всегда приходят книги, сопровождающие любое мероприятие библиотеки.

Особое место в мобильном библиотечном обслуживании занимают передвижные книжные пункты, дающие возможность выдачи документов библиотечного фонда вне стен библиотеки. На сегодня у нас 13 передвижных пунктов выдачи: 8 передвижек в детских садах и 5 в средних образовательных учреждениях. Передвижные пункты в детских садах мы комплектуем художественной детской литературой для дошкольников и методическими пособиями для воспитателей. В школах, как правило, выдаем периодические издания для детей и подростков. Помимо книговыдачи в план работы передвижек включены мероприятия: литературные часы, викторины, книжные обзоры для родителей и педагогов.

Формы мобильной работы могут быть различными. Все зависит от наличия интересных идей и возможностей их реализации. Так, в 2019 году, Новосибирская областная детская библиотека в партнерстве с Общественной некоммерческой организацией «Новосибирское библиотечное общество» приняла участие в конкурсе социально-значимых проектов министерства социальной политики Новосибирской области и получила субсидию на реализацию проекта «яблочные полки - дополняем реальность». Идея заключалось в том, чтобы при помощи специального программного приложения дополнить («оживить») страницы детских книг медиа элементами: видеофррагментами детских спектаклей новосибирских театров по конкретным произведениям. Основная целевая аудито-
«В гости к куклам!» - под таким девизом детская библиотека им. А. М. Горького порядка 10 лет организует мобильную площадку в Новосибирском областном театре кукол

Новосибирск крупный город с населением свыше полутора миллионов человек. Как и в любом мегаполисе, в нашем городе насыщенная культурная жизнь, которую поддерживают не только театры, музеи, концертные организации, но и библиотеки, а их в городе 76

Формы мобильной работы могут быть различными. Все зависит от наличия интересных идей и возможностей их реализации 


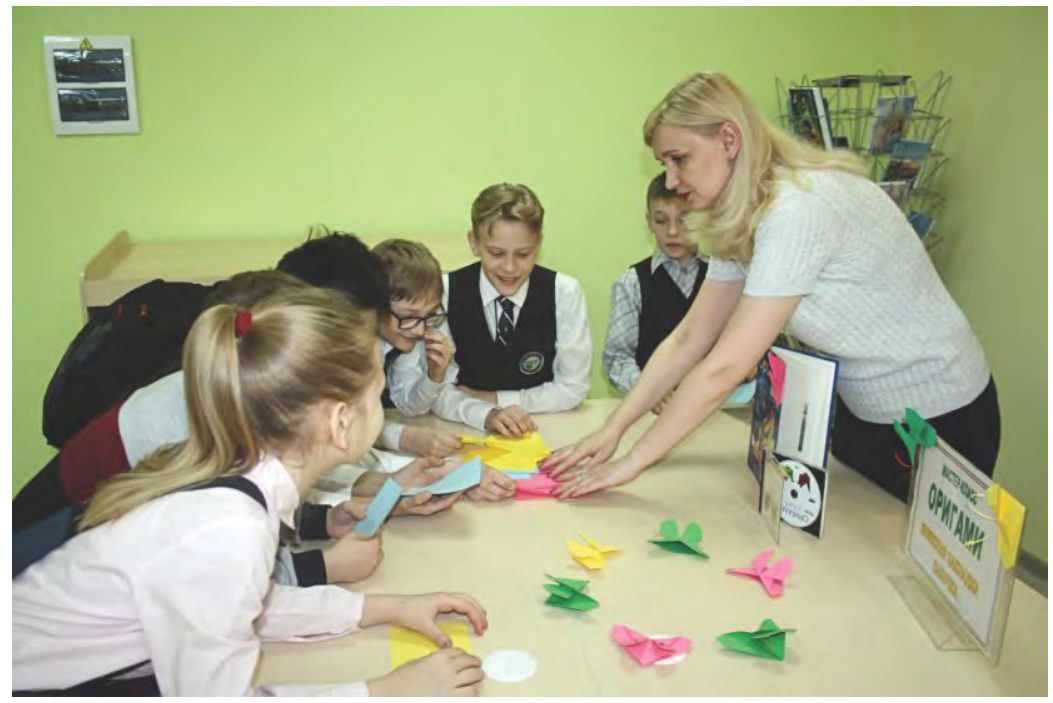

рия - учащиеся коррекционных школ. Дети с ослабленным интеллектом зачастую не могут читать. Чтобы сделать для этих детей книгу более доступной, а заодно приобщить к миру Дети театрального искусства, мы решили «ожис ослабленным интеллектом

зачастую

не могут читать.

Чтобы сделать для

этих детей книгу

более доступной,

а заодно

приобщить

к миру

театрального

искусства,

мы решили

«оживить»

страницы книг

при помощи

инорормационных

технологий вить» страницы книг при помощи инорормационных технологий. В состав «Яблочной полки» входят 10 произведений, по которым в разные годы ставились спектакли в новосибирских театрах, планшет с установленным на нем программным приложением, позволяющим «оживить» книжные страницы. Десять мобильных полок были отправлены в те районные библиотеки области, которые сотрудничают с коррекционными школами. Особенно это оказалось востребовано в тех уголках нашей области, где знакомство со спектаклями новосибирских театров становится малодоступным из-за территориальной отдаленности.

Думаю наш опыт наглядно демонстрирует возможности «библиотеки, не стоящей на месте». Где бы ни проходила работа мобильного библиотечного пункта: на вокзале, в пар- ке, театре, кинотеатре (у нас имеется и такой опыт), эта фрорма нестационарного обслуживания при правильно организованном процессе - от подбора ресурсов, подготовки рекламной продукции до проведения мероприятия - способна вызвать интерес у жителей и гостей города к книгам и библиотекам, привлечь новых читателей и создать привлекательный имидж библиотеки.

В заключении хочу добавить. С марта 2020 года, по объективным причинам - ограничениям, связанным с распространением новой коронавирусной инорекцией, мы были вынуждены временно приостановить акцию «Книга в дорогу», работу передвижных книжных пунктов в школах и детских садах, и прочие мероприятия, носящие мобильный, передвижной характер. Тем не менее, поиск идей для новых мероприятий вне библиотеки продолжается, и после снятия всех ограничительных мер, Новосибирская областная детская библиотека будет, как и раньше радовать, удивлять и вдохновлять своих читателей на встречу с книгой и новыми знаниями.

\section{Источники:}

1. Руководство ИФЛА по работе публичных библиотек. 2-е полн. пересм. изд./ ИФЛА, РБА; сост.К. Куни, Б.Габбин; научн. ред. изд. на рус. яз. В. Р. Фирсов. СПб.: Издво «Рос. нач. б-ка», 2011.

2. Руководство по мобильным библиотекам. Пересмотрено рабочей группой Секции публичных библиотек ИФЛА, координатор Иэн Стрингер. - The Hague, IFLA Headquarters. - 75p. - 30cm (IFLA Professional Reports; 123) Перевод с английского Э.Г. Азгальдов по инициативе и при поддержке Некоммерческого фонда «Пушкинская библиотека», 2010.

\footnotetext{
Ольга Костина - М. Горький номидаги Новосибирск вилоят Болалар кутубхонаси директори.

Муаллиф мақолада китобхонларга мобил хизмат кўрсатиш тури буцйчча амалга оширилаётган жараёнлар хақида батафсил баён этган. Кутубхона томонидан чекка жойларда истиқомат қцлувчи ах,ли эхтиёжлари учун керакли бўлган адабиётларни етказиб бериш орқали хизмат турининг самарали усули - библиобуслар хизматини жорий этилган. Мобил кутубхонанинг яна бир афзаллик жихати шундаки, у кўчма кутубхона сифатида одамлар кўп йивилиб, маданий тадбирлар ўтказадиган жойларда хозир бўлади. Кутубхонадаги ресурсларни оммалаштириш ва кенг тарвиб килиш мақсадида Новосибирск вилояти темир йўллари билан хамкорликда «Харакатдаги китоб» лойихаси хам ишга туширилган бўлиб, бугунги кунда у хизмат кўрсатишнинг энг самарали усулларидан бири деб тан олинмокда. Бунда поездда махсус вагон ажратилган бўлиб, керакли технологик ускуна ва мебеллар билан жихозланган. Хозирда у сафардаги йўловчиларнинг вақтларини кўнгилдагидек ўтказишлари учун хизмат қилмоқда ва йўловчилар орасида катта қизиқиш уйвотмокда.
} 
C XIV века нашей эры и до прихода Советской власти в Средней Азии чагатайскии язык был средством литературного творчества и исторических записей от Дели до Сибири и от Ирана до Бенгалии

Великий поэт Мир Алишер Навои, гигант в каноне чагатайской литературы, помог установить эталон композиции в языке

Самым ранним примером, хранящимся

в Британской библиотеке, является «Махзан аль-асрар», изданный в Казани в 1858 году тюркизировалось. По мере того, как при Тимуре оно достигло зенита своей политической и военной мощи, тюркские диалекты региона постепенно начали сливаться в качестве языка государственной власти. Qisas alanbiya Аль-Рабгузи, отражает этот этап перехода и появление «чагатая», как языка литературы и государственного управления. Военная доблесть ханства пошла на убыль в течение следующих трех столетий, но его культурное наследие продолжало расти. С XIV века нашей эры и до прихода Советской власти в Средней Азии чагатайскии язык был средством литературного творчества и исторических записей от Дели до Сибири и от Ирана до Бенгалии.

Проблема, однако, в том, что то, что было написано в Самарканде XV века н.э., не обязательно было тем же диалектом, что и в рукописи XIX века н.э. из Казаны или Кашгара. Как язык, у «чагатая» никогда не было государственного, институционально регулируемого стандарта, как в турецком, фрранцузском, фрилиппинском или корейском. Более того, не существует группы активных носителей языка, на которых можно было бы полагаться при проведении тестов на разборчивость речи, как если бы они читали лекции без глобальных стандартов, таких как английский, южный кечуа или йоруба. В результате тег «Чагатай» используется Библиотекой - и многими востоковедами, но не лингвистами - для описания совокупности произведений, демонстрирующих захватывающее дух количество языковых вариаций. Великий поэт Мир Алишер Навои, гигант в каноне чагатайской литературы, помог установить эталон композиции в языке. То же самое сделал Бабур, основатель династии Великих Моголов.

Авторы некоторых текстов относительно упрощают эту задачу, открыто заявляя, какие тексты они используют или обсуждают. Многочисленные рукописи содержат словари различных диалектов, а также объяснения различий в произношении, морфологии, синтаксисе и семантике между различными тюркскими общинами. Или 11042 слова, например, дает нам глоссарий слов, используемых кыргызскоговорящими в Бухаре. Составленный Мухаммадом Каримом аль-Булгари из Казани в XIX веке н.э., он был призван дать татарским студентам в Бухаре ключ к особенностям местных речевых образов, переведя эти слова на персидский и арабский языки.

Чагатайско-персидский кодекс, содержащий многочисленные лингвистические трактаты, представляет нам еще несколько вопросов номенклатуры. Скопированный в Индии в середине XIX века н.э., труд демонстрирует интерес ученых-моголов к различным тюркским диалектам. В первых трех текстах представлены грамматики и словари чагатайского, азербайджанского, ногайского и кашгарского языков, ни один из которых не создает слишком много проблем, когда речь идет о грубом определении современных языковых сообществ. Однако четвертый текст создает некоторую путаницу. Автор, которым, возможно, был Агур бин Байрам Али Би, утверждает, что тюркские народы разделены на два лагеря: аймаки, которые говорят такие вещи, как «гайда, хандай, кали и таш», и туркмены, которые говорят «хайда, хандай, гали и тире». Эти подразделения, похоже, отмечают некоторые фонологические различия, о которых мы знаем сегодня. Рассмотрим, например, казахский «каджет» и турецкий «хаджет» (что означает «потребность») или казахский «таш» и турецкий «даг» (что означает «гора»). Но помимо этого линии начинают расплываться.

Конечно, чагатай - это не только язык рукописей. На протяжении большей части XIX века н.э. литография также использовалась для воспроизведения текстов. Литография, в отличие от ранних подвижных шрисртов, помогла воспроизвести стиль каллиграфии насталик, распространенный во многих рукописях Центральной Азии. Однако также использовался подвижный шрифт, особенно в контексте программ европеизации, навязанных различными колониальными империями. В начале XIX века нашей эры печатные машины существовали в Казани (историю о нем написал Р. И. Якупов), а также в СанктПетербурге, и вскоре были открыты в Ташкенте, Оренбурге и Бухаре. Самым ранним примером, хранящимся в Британской библиотеке, является «Махзан аль-асрар», изданный в Казани в 1858 году (ITA.1986.a.1077). Монографрия была опубликована Джозефом Готвальдтом, профрессором арабского и персидского языков Казанского университета с 1849 по 1897 год. Готвальдт стал библиотекавостоковедом в университете в 1850 го-ду и возглавил его издательство с 1857 года, что еще раз продемонстрировало глубокую связь между востоковедческой наукой и из-данием чагатайской литературы.

Не все печатные издания чагатайской литературы были созданы в Императорской академии. Копия «Диван-и Машраб» (ORB.30 
( 8204), сборника стихов Бобораима Муллы Вали, сусрийского интеллектуала XVI-XVII веков н.э., также известного как Машраб, вероятно, была выпущена для удовольствия читателей из Центральной Азии. Это прекрасное издание было литографировано в Ташкенте в 1900 году и демонстрирует эстетические высоты, достижимые среднеазиатскими ремесленниками конца XIX века н.э. Это также дает нам четкий контраст с современными произведениями тюркских народов, подчеркивая растущую пропасть между литературными и просторечивыми способами выражения.

Периодический журнал «Шура» начала XX века (14499. tt.18), издаваемый в Оренбурге башкирским и татарским джадидом Ризаеддином Фахреддиновым (Ризаитдин Фәхретдин), представляет собой пример, демонстрирующий чагатайские и татарские черты. Среди них использование - ymyz вместо ybyz для первого лица множественного числа (особенность Chagatai) и появление tügel для отрицательной связки (распространено в татарском). Похоже, что Фахреддинов действовал по скользящей шкале, предпочитая более литературный стиль для социальных комментариев и, по иронии судьбы, более народный для литературныхпроизведений.

Сравните это с книгой Даври Алим (14499.р.5), рассказывающей о путешествиях Абдуррешита Ибрагимова (Габдрәшит Ибрацимов) по всему миру и их влиянии на национальное развитие. Он содержит элементы, общие для огузских диалектов (олмак, иле), а также особенности, которые можно найти в карлукских или кыпчакских диалектах (конструкции -gan past и -a tur). Это не чагатай, но и не узбекский, туркменский или татарский. Что тут происходит?

Возможно, мы наблюдаем что-то новое зарождающийся lingua franca для мусульманских тюркских общин по всей Евразии. Иногда он упоминается под простым прозвищем тюрки, как мы видим на обложке выпуска

Майкл Эрдман - Британия Миллий кутубхонасининг турк ва туркий нашрлар буйича мутахассиси.

Муаллиф маколада туркий халқларнинг кутубхоналари фондида сақланаётган чиватой ёзувидаги адабиётларни, тилшунослик атамалари билан бовликлиги хақида ўтказган тадқиқот натижалари хусусида фикр билдирган. Айниқса, Марказий Осиё худудида жойлашган туркий элатларни тарихий манбаларида келтирилган атамалар, ижтимоий ва интеллектуал жихатдан уцзаро ўхшаш сўзлар орқали акс этган. Туркий тиллар ёзувини дастлабки манба сифатида бизгача етиб келиши, бу ўрхун ёзуви бўлиб, миллодий VIII асрларда яратилган. Ўтган ўн уч аср давомида туркий ёзувлар таркалиши эволюцияси, асосан, биз билган чиватой диалектида шаклланиб келингани таъкидланади. Шунингдек, муаллиф хулоса ўрнида қадимги чиватой архив манбаларини замонавий туркий халқлар оммасига сифатли етказиб бериш буйича бир қанча таклифларини берган. среди изгнанников из различных тюркских
Ойна (ITA.1986.а.1625) за 1914 год. Несомненно, были предложены другие типы общих тюркских систем - наиболее известные из которых был выдвинут Исмаилом Гаспирали, но, похоже, ни один из них не получил безоговорочной поддержки, как среди интеллектуалов, так и среди среднестатистических тюркоязычных людей. Специалист по восточноским текстам, литературной культуре и тил внимание на широко распространенное присутствие междиалектного тюрки и в восточно-туркестанских документах. Нам еще многое предстоит понять об этом явлении и о том, как он связан с Чагатай в лингвистическом, историческом, социальном и политичес-

Чагатай проиграл целому ряду полуязычных, жестко управляемых языков - узбекского, татарского, башкирского, казахского, киргизского и туркменского и других - которые стали новыми литературными нормами. Чагатай, а может быть, тюрки, не вымерли полностью, а прожили еще какое-то время в .t.40) в другом месте, но стоит упомянуть еще раз, как пример продолжающегося использования языка в качестве общего знаменателя общин, по крайней мере, до конца 1930-х годов. Тем не менее, тихое исчезновение Чагатая с мировой сцены лишило нас возможности по-настоящему понять, чем он был и увикультурной продукции. А для сообщества каталогизаторов и кураторов это означает постоянную борьбу за категоризацию этих произведений таким образом, чтобы сделать их доступными для поиска и использования читателями со всего мира. Мы надеемся, что со К ним и к самому языку возродит важность Чагатая для понимания истории Евразии.

\section{Специалист}

по восточно-

тюркским текстам, литературной культуре и многоязычию Ахмет Ходжам Пекиний обратил внимание на широко распространенное присутствие междиалектного тюрки и в восточнотуркестанских документах 
АХБОРОТ-КУТУБХОНА

МУАССАСАЛАРИНИ

РИВОЖЛАНТИРИШДА ФАОЛИЯТ

САМАРАДОРЛИГИНИ

БАХОЛАЙДИГАН МЕЗОНЛАРДАН ФОЙДАЛАНИШ ИСТИҚБОЛЛАРИ

\section{dol $10.47267 / 2181-8207 / 2020 / 3-033$}

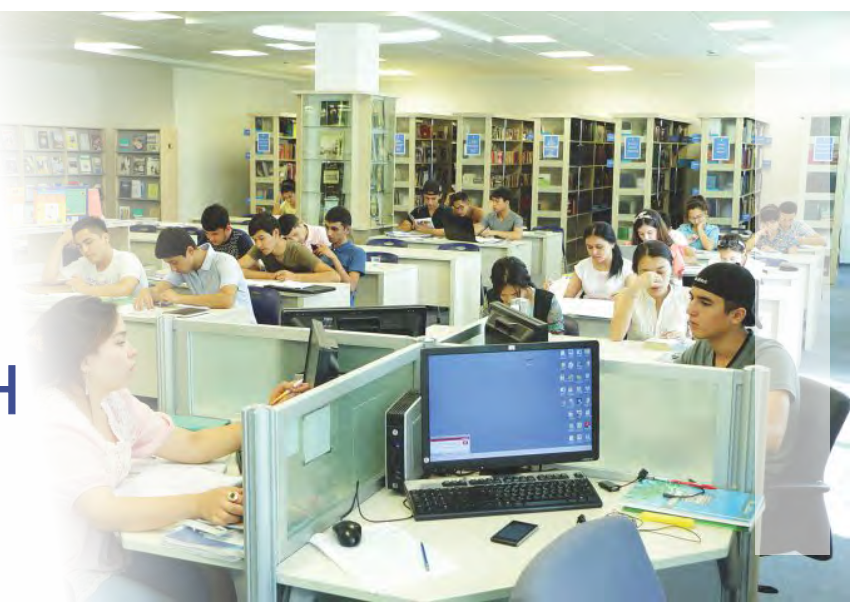

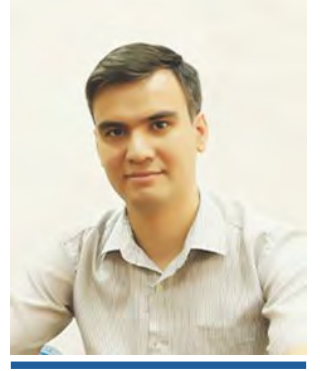

Тимур Ахмедов,

Тошкент ахборот

технологиялари университети 2 курс магистранти

The article examines the ongoing reforms in Uzbekistan, in particular, analyzes the decrees, concepts and programs for the development of the information and library sphere. The author examines research conducted abroad on the development of special criteria for assessing the effectiveness of information and library activities, the creation of statistical databases. Taking into account international experience, a solution to this issue is proposed.

Таянч суузлар: Харакатлар стратегияси, ахборот-кутубхона муассасалари, самарадорлигини бахолаш, бахолаш моделлари, бахолаш мезонлари, ISO-11620, IFLA.

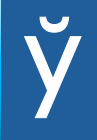

збекистон Республикасини ривожлантиришнинг бешта устувор йўналиши бўйича 2017-2021 йилларда Харакатлар стратегиясини амалга ошириш доирасида барча сохалардаги бўлгани каби республикада ахборот-кутубхона сохасини ривожлантиришга хам катта урғу берилди.

Хусусан, Ўзбекистон Республикаси Президентнинг 2019 йил 7 июндаги Қарорига асосан 2019-2024 йилларда Ўзбекистон Республикасида ахборот-кутубхона сохасини ривожлантириш концепцияси ва чора-тадбирлар дастури қабул қилинди. Шунингдек, Миллий кутубхона қошида 186 та туман (шахар) ахборот-кутубхона марказлари ташкил этилиши, айни пайтда умумтаълим мактаблари ва ўрта махсус, касб-хунар таълими муассасалари қошида фраолият кўрсатаётган барча ахборот-ресурс марказлари эса тугатилиши кўзда тутилган. Шу билан бирга, умумтаълим мактаблари ва уурта махсус, касб-хунар таълими муассасаларининг кутубхоналари сақланиб қолиниши кўрсатибўтилган. ${ }^{1}$

Ўзбекистон Республикаси Президентининг «Ўзбекистон Республикаси ахолисига ахборот-кутубхона хизмати кўрсатишни яна- да такомиллаштириш тўғрисида»ги қарорида таъкидланганидек, республикада ижтимоийиқтисодий сохани ислох қилишнинг хозирги шароитида ахборот-кутубхона фраолиятини ривожлантиришнинг мақсад ва вазифралари мамлакатда амалга оширилаётган ўзгаришларга ва халқаро амалиётга мос бўлиши заpyp.

Мазкур Қарорда асосий вазифалар қаторида ахборот-коммуникация технологияларининг ривожланиши ва замонавий умумжахон тенденцияларини хисобга олган холда ахборот-кутубхона фраолиятини ислох қилиш; ахолига ахборот-кутубхона хизматлари кўрсатиш бўйича ижтимоий кафролатларни сифратли таъминлаш хамда замонавий талабларни хисобга олган холда, ахборот-кутубхона муассасаларини ривожлантириш мақсадида норматив-хуқуқий базани такомиллаштириш; ахборот-кутубхона муассасаларини малакали мутахассислар билан таъминлаш кўрсатилди. ${ }^{2}$

Бироқ назарда ахборот-кутубхона фраолияти самарадорлигини бахолайдиган махсус мезонларни ишлаб чиқиш, статистик базаларни яратиш каби масалаларга эътибор бироз сустдай кўринмоқда. Вахоланки, сўнг-

\footnotetext{
186 та ахборот-кутубхона марказлари очилади, кутубхоначилар куни нишонланади, - https://www.norma.uz/uz/qonunchilikda_yangi/186_ta_ahborot-kutubhona_markazlari_ochiladi_kutubhonachilar_kuni_nishonlanadi.

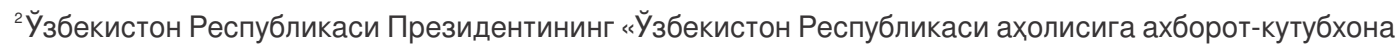
хизмати кўрсатишни янада такомиллаштириш тўғрисида»ги Қарори // Ўзбекистон Республикаси Қонун хужжатлари маълумотлари миллий базаси, 07.06.2019 й.
} 
ги йилларда халқаро миқёсда соха жадал суратларда ривожланди, янги тенденциялар пайдо бўлди.

Бу эса ахборот-кутубхона сохаси фаолиятини бахолаш бўйича анча изланишлар олиб бориш ва халқаро меъёрларни кенг қўллаган холда миллий тизимни ишлаб чиқиш зарурияти борлигини кўрсатади. Масаланинг иккинчи томони бугунги кунда Ўзбекистонда 12 мингга яқин кутубхоналар мавжудлиги, уларнинг имконияти ва иноратузилмаси турли-туманлигини хисобга олган холда қайси муассаса берилган имкониятлардан тўғри фройдаланиб, ахолига сифратли хизмат кўрсатаётганлиги аниқлаш бугунги кунинг долзарб вазифралари қаторида турибди.

Ўтган асрнинг 70-йилларида бир қатор рус олимлари, шулар жумласидан, Н.С.Карташов, Л.А.Кожевникова, Ж.С.Шадрин, Ю.П. Столяров ахборот-кутубхона фраолияти самарадорлигини турли мезонлар билан бахолаш борасида изланишлар олиб боришган бўлса, XXI асрда ғарб олимлари П.Роуз, Р.Полл, Петер те Бокхорстлар, П.Брофи ўлчов ва бахолаш кўрсаткичларни яратиш хамда тахлил қилиш борасида ўз изланишларини кенг оммага тақдим этишди.

Мазкур тадқиқотларда кутубхона фраолияти ва сифат даражасини акс эттирувчи кўрсаткичлар ва мезонларни аниқлаш, мавжуд усулларни тахлил қилиш, турли хил ва турли йўналишдаги кутубхоналар ишини бахолаш учун моделлар (тизимлар) ишлаб чиқишга урғу берилган.

Ахборот-кутубхона фаолиятининг самарадорлигини сифат жихатидан ўлчаш учун кўрсаткичлар тўпламини ишлаб чиқиш мураккаб муаммо хисобланади. Мутахассислар фрикрича, бунинг учун, аввало, мазкур фраолиятдаги хар бир жараённи чуқур тахлил қилиш талаб этилади. Ахборот-кутубхона муассасалари фраолиятининг самарадорлигини бахолаш мезонларини хаётга татбиқ этиш орқали инсон капитали, ахоли саводхонлик даражаси ва давлатнинг инновацион тараққиётига таъсирини янада кучайтириш ва бу борада аниқ харакатлар режасини ишлаб чиқишга замин яратади.

Хорижий кутубхонашуносликда, асосан Шимолий Америкада кутубхона фраолиятини бахолаш учун турли хил усулларни яратишга бўлган биринчи уринишлар XIX аср охири $\mathrm{XX}$ аср бошларига тўғри келади. Аммо самарадорликни бахолаш усулларини яратиш бўйича тизимли ёндашувнинг бошланиши ва бахолаш методологиясини яратилиши Шимолий Америка фралсафий ва тизимли ёндашув тарафдори Ф.Морз (Р.M. Morse) номи билан боғлиқ. У ўзининг назариясини 1968 йилда нашр этган «Кутубхона самарадорлиги: тизимли ёндашув ${ }^{3}$ китобида тўлиқ акс эттирди. Шу даврдан бошлаб кўплаб кутубхоначиларнинг тадқиқотлари ва назарий ишланмалари тизимли ёндашувга асосланиб, бу ушбу сохада муваффрақиятли натижаларга олиб келди.

П.Лабонинг таъкидлашича, ${ }^{4}$ ахборот-кутубхона фраолиятининг сиорати ва самарадорлигини бахолаш соха бошқарувининг мухим таркибий қисми хисобланади. Одатда, муассаса фралиятини бахолаш, авваламбор, аниқ ва равшан вазифаларни шакллантиришдан бошланади, бу эса, бахолашнинг энг долзарб воситаларини танлаш имкониятини беради.

Ахборот-кутубхона фраолияти самарадорлигини бахолаш кўрсаткичларининг ривожланиши реал бошқарув амалиёти эхтиёжлари, бюджет маблағларини сарорлаш самарадорлигига қаратилгани билан хам ахамиятлидир.

Н.Редькина ўз ишида қуйидагиларни баён этади. «Ахборот-кутубхона муассасининг салохияти ва фраолиятининг самарадорлигини тахлил қилиш буйича тўпланган тажрибани ўрганиб чиқиб, бахолаш тизимларини қуйидаги таркибий қисмларга ажратиш лозим: ўлчов мақсадлари - қандай муаммоларни ечишга қаратилганлигини аниқлайди; ўлчов таркиби - моделни қуриш тамойиллари, унинг кўрсаткичлари, мезонлар таркибини ўрганади; ўлчаш усуллари - керакли маълумотларни олиш, ўлчаш усулларини белгилайди; ўлчов стратегияси - унга мувофик маълумотларга ишлов бериш ва фройдаланувчига етказиш воситалар (усуллар ва технологиялар) тўпламини ўз ичига олади. Шу боис, ахборот-кутубхона самарадорлигини бахолаш учун тегишли мезонларни шакллантириш, кўрсаткич ва усулларни аниқлаш ва ўлчов тизимини яратиш керак».

Ўз навбатида, бир қатор рус олимлари кейинги йилларда ахборот-кутубхоналар фрао-
Бугунги кунда

Ўзбекистонда

12 мингга яқин кутубхоналар мавжудлиги, уларнинг имконияти ва инфратузилмаси турли-туманлигини хисобга олган холда қайси муассаса берилган имкониятлардан тўғри фройдаланиб, ахолига сифатли хизмат кўрсатаётганлиги аниқлаш бугунги кунинг долзарб вазифралари қаторида турибди

Ахборот-кутубхона муассасалари фаолиятининг самарадорлигини бахолаш мезонларини хаётга татбиқ этиш орқали инсон капитали, ахоли саводхонлик даражаси ва давлатнинг инновацион тараққиётига таъсирини янада кучайтириш ва бу борада аниқ харакатлар режасини ишлаб чиқишга замин яратади

\footnotetext{
${ }^{3}$ Morse P.M. Library effectiveness: A systems approach. Cambridge, Mass.: The M.I.T. Press, 1968. 207 p.

${ }^{4}$ Лабо П. Оценка деятельности библиотек: тенденции, приоритеты, показатели, - http://www.myshared.ru/slide/1320513/

${ }^{5}$ Редькина Н. С.Измерение эфрфективности работы библиотек //Библиосфрера, 2009, № 1, с. 63.72
} 
кейинги йилларда ахборот-

кутубхоналар

фраолиятидаги

жиддий ўзгаришлар муносабати билан

уларнинг

фраолиятини

бахолайдиган

кўрсаткичларни қайта кўриб чиқиш зарурлигини

таъкидлашмоқда.

Бунда, асосан,

статистик

кўрсаткичларга таяниш лозимлиги айтилмоқда

Статистик кўрсаткичлар

тўпламини

шакллантириш

орқали

ахборот-кутубхона

рахбарлари

ва уларнинг

муассислари

ишлар холатини

бахолаб,

мyасcaca

фраолиятининг

қиёсий тахлилини

ўтказиш

имкониятига эга бўлишади лиятидаги жиддий ўзгаришлар муносабати билан уларнинг фраолиятини бахолайдиган кўрсаткичларни қайта кўриб чиқиш зарурлигини таъкидлашмоқда. ${ }^{6}$ Бунда, асосан, статистик кўрсаткичларга таяниш лозимлиги айтилмоқда. Уларнинг орикрича, статистик кўрсаткичлар тўпламини шакллантириш орқали ахборот-кутубхона рахбарлари ва уларнинг муассислари ишлар холатини бахолаб, муассаса фраолиятининг қиёсий тахлилини ўтказиш имкониятига эга бўлишади. Бу борада статистик кўрсаткичлар ва уларни хисоблаш бирликларини халқаро тавсияларга (ISO ва IFLA стандартлари) ва махаллий кутубхоналар иш тажрибасига мувофиқлаштириш зарур.

Айрим давлатларда, хусусан, Молдова Республикаси Миллий кутубхонаси ва Саха Республикаси Миллий кутубхонаси (Якутия) фраолиятини бахолаш усуллари ISO-116207 «Кутубхоналар самарадорлиги кўрсаткичлари» халқаро стандарти асосида ишлаб чиқилган. Мазкур ёндашув натижаси ўлароқ, харажатлар оптималлаштирилиб кутубхона хизмати сифати кўтарилди ва ўқувчилар аудиторияси кенгайишига эришилди.

Ўзбекистон шароитида ахборот-кутубхона муассасалари ораолияти самарадорлигини бахолаш мезонларини яратиш мазкур муассасаларнинг иш сифратини ошириш, харажатларни минималлаштириш, сохани стратегик ва инновацион ривожланишига хизмат қилиши мумкин.

Қўйилган мақсадни амалга ошириш учун ахборот-кутубхона фраолиятининг самарадорлигини тавсифловчи асосий халқаро ва миллий кўрсаткичлар ва стандартларни тахлил қилиш, бахолаш мезонлари тушунчасининг мохиятини назарий жихатдан асослаш, мезонлар ишлаб чиқиш методларини классифрикациялаш ва хусусиятларини аниқлаш, илғор халқаро тажрибани уурганиш асосида Ўзбекистонда фраолият олиб бораётган ахбо- рот-кутубхона муассасалари самарадорлигини бахолаш мезонларини ишлаб чиқиш талаб этилади.

Ахборот-кутубхона фраолиятини самарали ташкил этишга қаратилган ушбу изланишлар уззбекистонлик соха мутахассислари ва кенг жамоатчиликда катта қизиқиш уйғотиши хамда мазкур йўналишни ривожлантиришга хизмат қилиши мумкин.

Фойдаланилган адабиётлар руцйхати

1. Ўзбекистон Республикаси Президентининг «Ўзбекистон Республикасини янада ривожлантириш буйича харакатлар стратегияси туцврисида»ги Фармони // ЎЗР. Қонун хужжатлари маблумотлари миллий базаси, 07.02. - 2017 й.

2. Ўзбекистон Республикаси Президентининг «Ўзбекистон Республикаси ах,олисига ахборот-кутубхона хизмати кўрса тишни янада такомиллаштириш тугрисида»ги Қарори // Ўзбекистон Республикаси Қонун хужжатлари маблумотлари миллий базаси, 07.06.2019 й.

3. Ахборот-кутубхона ва ахборот-ресурс марказлари ишини ташкил қилиш (хужжатлар тупллами) // Ўзбекистон Миллий кутубхонаси, Т.: 2007 й.

4. Morse P.M. Library effectiveness: A systems approach. Cambridge, Mass.: The M.I.T. Press, $1968.207 p$.

6. Лабо П. Оценка деятельности библиотек: тендениии, приоритеты, показатели, - http://www.myshared.ru/slide/1320-513/

7. Редькина Н. С.Измерение эффективности работы библиотек // Библиосфера, 2009 , № 1, c. 63.72

8. Стандарты ИФЛА: Руководство ИФЛА по повышению профессиональной квалификации: принципы и рекомендации; Справочная модель библиотеки ИФЛА (LRM); Рекомендации по непрерывному профессиональному развитию: приниипы и передовой опыт; Рекомендации для удобных для чтения материалов; Рекомендаиии ИФЛА по обслуживанию публичных библиотек-https://www.ifla.org/standards.

\footnotetext{
Тимур Ахмедов - магистрант 2 курса Ташкентского университета информационных технологий.

Маколада Ўзбекистонда амалга оширилаётган ислохотлар, хусусан ахборот-кутубхона сохасини ривожлантиришга оид карор, концепция ва дастурлар тахлили келтирилган. Муаллиф ахборот-кутубхона фаолияти самарадорлигини бах,лайдиган махсус мезонларни ишлаб чикиш, статистик базаларни яратиш борасида хорижда олиб борилаётган изланишларга назар ташлаган. Халқаро тажрибани хисобга олган холда мазкур масала ва унинг ечимига эътибор қаратилган.
}

\footnotetext{
${ }^{6}$ Дворкина М.Я., Джиго А.А., Майстрович Т.В. Библиотечная статистика: новый российский стандарт // «Университетская книга», 2014, №5

${ }^{7}$ ISO 11620:2014 Information and documentation - Library performance indicators. - https://www.iso.org/standard/56755.html
}

«INFOLIB» ахборот-кутубхона журнали. №4 (24) 2020 


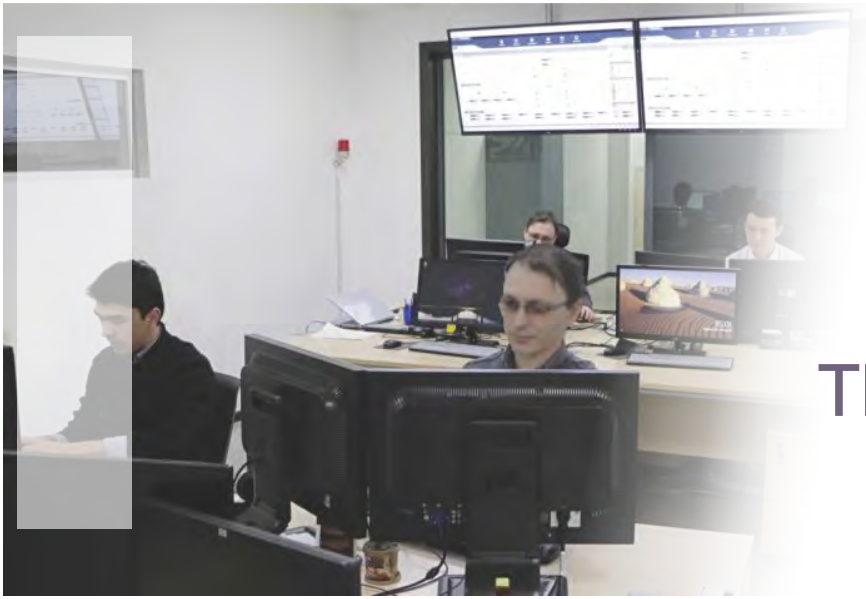

\section{ИСТОРИЯ ДЕЯТЕЛЬНОСТИ СЛУЖБЫ ИНФОРМАЦИОННО- КОММУНИКАЦИОННЫХ ТЕХНОЛОГИЙ НАЦИОНАЛЬНОЙ БИБЛИОТЕКИ УЗБЕКИСТАНА}

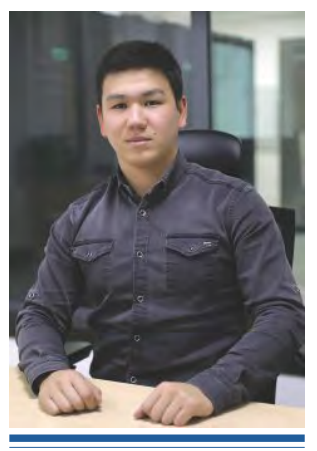

Сардор Холбоев, специалист

I категории Службы администрирования сети и поддержки серверного оборудования Национальной библиотеки Узбекистана

Библиотека участница ряда научноисследовательских проектов, которые

отличаются

многоаспектностью

и направлены на

совершенствование

инорормационно-

библиотечного

дела, подготовку

высококвали-

фрицированных

кадров

The article considers the library as a participant in a number of research projects, which are distinguished by their multi-aspect nature and are aimed at improving the information and library business. Information technologies in libraries, development of research methods and means of forming a national electronic catalog and access to it the study of the information culture of young people, the culture of reading is the main, but not a complete list of scientific developments of the library team. The author suggests for further development of the information and library system by information technologies, it is necessary to pay special attention to providing the material base and storing information in the service with server equipment.

Ключевые слова: научно исследовательские, многоаспектность, информационные технологии, исследовательских методов, электронного каталога, библиотечной системы.

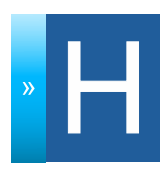
а сегодняшний день перспективы библиотеки связаны с совершенствованием информационного обслуживания пользователей на основе новейших информационных и коммуникационных технологий. Внедрение новых технологий вызвало изменения традиционных технологических процессов, что повлекло за собой реорганизацию функциональных отделов: в начале 1999 г. был организован отдел автоматизации и новых инфрормационных технологий, создана локальная автоматизированная сеть.

Библиотека участница ряда научно-исследовательских проектов, которые отличаются многоаспектностью и направлены на совершенствование информационно-библиотечного дела, подготовку высококвалифицированных кадров. Информационные технологии в библиотеках, разработка исследовательских методов и средств формирования национального электронного каталога и доступа к нему, изучение информационной культуры молодежи, культура чтения - это основной, но далеко не полный перечень научных разработок коллектива библиотеки.

Для дальнейшего развития инфрормационно-библиотечной системы инорормационными технологиями, необходимо уделять особое внимание обеспечению материальной базой и сохранению информации в службе сервиса серверным оборудованием. И первые шаги серверного сервиса были начаты в 1999 году. Общий объём по хранению информации был всего мощностью 80 Гб, что могло размещать всего инфрормации, например, 350 научных диссертаций. За прошедшие 20 лет мощность объёма серверного оборудования достигла 300 Тб, работающей в активном режиме, а также 300 Тб, работающей в резервном режиме, что позволяет в случае выхода из строя сервера активного режима, параллельно сохранять инорормацию в сервере резервного режима. Эта технология позволяет сохранить около 2,5 млн. печатных изданий, если постранично получается 750 млн. страниц. На сегодняшний день на сервере фрункционирует 10 электронных сайтов, в основном базирующихся на портале «natlib.UZ», под этим доменом расположена программа «uznel», которая фрормирует базы данных электронной каталогизации печатных изданий и полнотекстовых записей национальной библиографиии, кроме этого программой пользуются служба комплектования информационных библиотечных фрондов и другие.

Основным пользователем серверного сервиса является служба сканирования и оцифровки печатных изданий. Книжные издания различных фрорматов, периодические издания газет и журналов, издания из кол- 


\section{1 Книжных изданий раз- личных фрорматов 57616 экз. или 17284800 страниц;

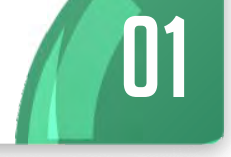 \\ 04}

Периодических изданий газет и журналов оцифровано 112905 экземпляров

\section{гов}
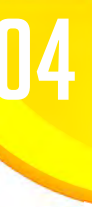

(1) 03

Книг из отдела

02 редких фрондов оцифровано 3285 эКз. или 1314000 страниц

\section{Инфографрия 1.}

лекции редких фондов сканируются и после обработки архивируются и отправляются на хранение на сервер для дальнейшего пользования. В возведенном в 2012 году новом здании Национальной библиотеки Узбекистана начал свою деятельность центр оцифровки и сканирования. За прошедший год отделом было оцифровано книжных изданий, включая авторефераты, научные диссертации и другие фонды в общем количестве 201166 единиц (19 419600 страниц) инфрографрия1.

Служба сканирования и оцифровки полностью фрормирует нормативно-методические и другие базы данных для Национальной библиотеки Узбекистана - это «uznel.natlib.uZ», «press.natlib.uz», «nodir.natlib.uz», «diss.natlib.uz», «journal.natlib.uz», «qr.natlib.uz», koторые хранятся в электронном виде на серверном оборудовании.

Чтобы не оцифровывать копии печатных изданий, имеющихся в фрондах библиотеки в 2-3 экземплярах, была разработана программа «ВООК». C помощью этой программы эффективность и действенность службы значительно возросла по сравнению с предыдущими годами, то есть во избежание повтора оцифрровки копий, проверяется количество печатных изданий в других службах и оцифровывается одна копия.

В 2018 году в Национальной библиотеке Узбекистана имени Алишера Навои был реализован проект «Национальная общеобразовательная электронная библиотека». Актуальность данного проекта в первую очередь направлена на развитие в Республике электронной информационно-библиотечной системы, основной целью которой является дальнейшее совершенствование инорормационно-библиотечного обслуживания населения. В рамках проекта UzNel автоматизированная информационно-библиотечная система, объединяющая 21 крупные инсрормационно-библиотечные учреждения Республики, является координирующим органом по обмену и использованию инфрормации, по обеспечению и эсрфективному предоставлению информационных услуг различным слоям населения. В соответствии с постановлением Президента Республики Узбекистан от 7 июня 2019 года № ПП-4354 «О дальнейшем совершенствовании инорормационно-библиотечного обслуживания населения Республики Узбекистан» Служба сканирования и оцифровки создана как структура Национального общеобразовательного центра электронной библиотеки Узбекистана имени Алишера Навои. Из этого следует, что масштаб работы сервиса свидетельствует о быстром росте его планов на будущее. В ближайшие 2020-2025 годы планируется полная оцифровка фрондов Национальной библиотеки и пополнение нормативно-методической базы электронными изданиями. Оснащена служба современным технологическим оборудованием, производителем которой является немецкая компания «Micro book». Многофункционирующее цифровое оборудование предназначено для оцифровки печатных изданий различных форматов.

Целью данной работы является предоставление пользователям услуг на уровне мировых стандартов, то есть создание возможности удаленного доступа к электронным информационно-библиотечным ресурсам и мультимедийным продуктам.

Проводятся занятия для региональных специалистов по повышению квалисрикации по оцифровке печатных изданий, включающих теоретические и практические занятия в целях укрепления их знаний и навыков на проорессиональном уровне.

В рамках проекта «Национальная общеобразовательная электронная библиотека» было установлено оборудование для аудио и видео студий, в которых на профессиональном уровне можно будет заниматься записями с творческими личностями. «Книга у микрофона» - под таким девизом в аудио студии создаются аудио книги для людей с ограниченными возможностями и таким способом распространяются подготовленные аудио материалы для библиотек, которые обслуживают незрячих пользователей. При Министерстве 
культуры Узбекистана существуют около 90 библиотек для незрячих пользователей и этот метод даёт возможность пополнения фонда и создает благоприятные условия для посетителей библиотек. Специалистами мультимедийной студии одной из первых аудио книг создана книга под названием «Уфқ» в переводе «Горизонт», написанная Народным писателем и героем Узбекистана Саид Ахмадом, продолжительность аудио книги составляет 12 часов 38 минут и запись можно слушать в Мр3 фрормате. Также было записано одно из классических произведений писателя Чулпана под названием «Кеча ва кундуз», что в переводе значит «День и ночь» и продолжительность аудио книги составляет 17 часов 48 минут. Кроме этого записана аудио книга писателя Миркарима Осима под названием «Тумарис», продолжительность аудио книги составляет 13 часов 45минут. Записанных аудио книг уже несколько десятков и специалистами Национальной библиотеки продолжается работа по созданию аудио книги с привлечением волонтёров для чтения.

Ещё одна уникальность функционирования аудио студии - это перезапись старых грампластинок, находящихся в службе хранения общих фрондов, где применяются специальные запрограммированные эффректы и в результате появляется более эффрективный голосовой трек. На сегодняшний день имеющаяся конвертация медиа ресурсов в Национальной библиотеке составляет 217 экземпляров оцифрованных грампластинок, также переведены на MP3 фрормат 121 грампластинка.

В социальном проекте очень удобно создавать голосовые рекламные объявления, которые можно будет запускать в социальной сети facebook и Telegram каналах, в этом случае при пропаганде культуры чтения для распространения в различных слоях населения. В аудио студии часто организуются вечера поэзии, записываются интервью с поэтами, такими как Шукур Курбон, Фарида Асрруз, Азим Суюн и многими известными творческими личностями Узбекистана. Вся записанная инорормация хранится на сервере Национальной библиотеки Узбекистана, на портале natlib.uz пользователям и всем желающим можно будет ознакомиться с ней в электронном архиве библиотеки.

В мультимедийной студии можно особо отметить работу видеосъёмки - это презентации новых книг с участием авторов, ин- тервью с ними становятся документальным видеосюжетом. Кроме этого можно подготовить короткометражные ролики о книгах и журналах и в дальнейшем их можно разместить на канале YouTube.com. В последнее время практикуется дистанционное обучение специалистов библиотечной сфреры в онлайн режиме, это вид обучения очень удобен для региональных инорормационно-библиотечных учреждений, которые находятся в отдаленных краях нашей Республики. В основном темами проводимых онлайн занятий являются: обучение организации современных инорормационно-библиотечных видов деятельности, виртуальное обслуживание читателей, оформление полнотекстовых библиограсрических записей, дистанционное обеспечение инорормации для пользователей, правила применения каталогизации печатных изданий и правильное использование стандартов, а также методы оцифровки инфрормационно-библиотечных фондов. За 2019 год в мультимедийной студии было произведено 53 вида различных видеомонтажей, некоторые проводятся на регулярной основе - это видео клуб «Читающая мама», проводимые социологические опросы и интервью на центральном улицах Ташкента с горожанами и гостями столицы «О культуре чтения среди населения». Проводятся и записываются интервью с деятелями науки Узбекистана, а также со специалистами ближнего и дальнего зарубежья, например, беседа с доктором фрилософрских наук, профессором Иброхим Хаккулом, одна из актуальных тем: «Тенденции развития современного чтения среди молодёжи», интервью с экспертом ЮНЕСКО, доктором педагогических наук, профрессором, заслуженным деятелем науки Натальей Гендиной по теме: «Тренинг тренеров по медийно-информационной грамотности инфрормационной культуры в Узбекистане». Вся данная видео инорормация сохраняется в базе мультимедийного архива. Студия продолжает запускать проекты по созданию буктрейлеров различных фрорматов, разрабатывает слайд-шоу для виртуальныхвыставок.

Республиканский центр сводного электронного каталога (РЦСЭК) создан в соответствии с Постановлением Президента Республики Узбекистан №1487 от 23 февраля 2011 года «О мерах по дальнейшему качественному развитию инсрормационно-библиотечного и инорормационно-ресурсного обслуживания на базе инфрормационно-коммуни- функционирования

аудио студии - это

перезапись старых грампластинок, находящихся в службе хранения общих фондов, где применяются специальные запрограммированные эфроекты и в результате появляется более эфрфективный голосовой трек

За 2019 год в мультимедийной студии было произведено 53 вида различных видеомонтажей, некоторые проводятся на регулярной основе - это видео клуб «Читающая мама», проводимые социологические опросы и интервью на центральном улицах Ташкента с горожанами и гостями столицы 
Онлайн программа

Сводный

электронный каталог (СЭК) -

отражает

библиографрическую

инорормацию о

фондах библиотек.

Все пользователи

независимо от их

местонахождения

получают

свободный доступ

в режиме реального

времени $\mathrm{k}$

библиографической

инорормации

о фрондах библиотек

Республиканский

центр сводного

электронного

каталога

осуществляет

работу по быстрому

обмену

инорормацией

между

республиканскими

инорормационно-

библиотечными

учреждениями,

организует единый

каталог базы

данных кационных технологий на 2011-2015 гг.». РЦСЭК осуществляет свою деятельность и функционирует на базе Национальной библиотеки Узбекистана в соответствии с законодательством Республики Узбекистан.

В 2013 году была запущена в тестовом режиме первая онлайн программа Сводный электронный каталог (СЭК) которая имеет электронные каталоги библиотек и библиографические базы данных. Республиканский центр сводного электронного каталога осуществляет работу по быстрому обмену информацией между республиканскими информационно-библиотечными учреждениями, организует единый каталог базы данных, контролирует и обеспечивает высокое качество библиографических записей в электронном каталоге и координирует деятельность инорормационно-библиотечных учреждений по обмену инфрормацией.

В центре функционируют две службы

- Служба каталогизации и редактирования.

- Служба технического обеспечения и внешней связи.

Каталогизация и редактирование - Ocновная задача отдела вести контроль библиографических записей, не допускать их повтора и обеспечить их качество.

Техническое обеспечение и внешние связи. Устанавливает активные связи между информационно-библиотечными учреждениями. Обеспечивает защиту базы СЭК, резервное копирование, архивирование записей, защиту от несанкционированного доступа и вирусов, дублирование в целях coxранности и т.д.

Онлайн программа Сводный электронный каталог (СЭК) - отражает библиографическую информацию о фондах библиотек.

Все пользователи независимо от их местонахождения получают свободный доступ в режиме реального времени к библиограсической информации о фондах библиотек. В инфрормации о найденном документе содержатся сведения о месте и шисррах его хранения, а также возможности удаленного заказа документов из фондов информационно-библиотечных учреждений. Эффрективность программы СЭК оценивается как предоставление эффрективных возможностей для фрормирования частных локальных электронных каталогов в инфрормационно-библиотечных заведениях Республики Узбекистан.

В службе формирования Национальных база данных после 2000 года начались рабо- ты по созданию электронного карточного указателя периодических изданий, первоначально внедрили программу ИРБИС, а затем начали работать в программе АИБИС, с 2019 года переведена конвертация в программу UZNEL и было включено более 120000 библиографрических записей. Кроме того служба создала полнотекстовую базу данных «Карши - 2007» в связи с юбилеем города Карши в 2006 году. Создана электронная база данных нормативных документов, создано более 40 полнотекстовых электронных пособий, вся инорормация службы сохраняется на базе сервера Национальной библиотеки.

Служба комплектования информационнобиблиотечных фондов занимается фрормированием поступлений и оформлением печатных изданий Национального библиотеки. C 2007 года отдел начал применять информационно-коммуникационные технологии в офрормлении книжных и периодических изданий. Как и все службы, служба комплектования первоначально применяла программу ИРБИС и в дальнейшем с переходом в программу АИБИС, с развитием в области ИКТ, совместно с специалистами - программистами внедрены автоматизированные программы «stat.natlib.uz» - программа статистического учета книг и периодических изданий, также программа База данных для научных диссертаций, которые поступают из Академии наук Узбекистана «diss.natlib.uz». Последний результат - это внедрение программы Uznel в рамках Национальной общеобразовательной электронной библиотеки, в базу данных которой была введено: 13841 наименований книг, плакатов и открыток - 243 экземпляра, 185 географических и исторических карт, научных работ и авторесрератов 1761 экземпляр, также 365 научных журналов и 827 газетных изданий. Кроме этого с 2006 по 2019 годы было создано 252427 библиографических записей по IBS и в программах, созданных и используемых в библиотеке. Все данные службы комплектования информационно-библиотечных фрондов сохраняются в электронном архиве Национальной библиотеки Узбекистана.

C внедрением в 1998 г. и в дальнейшем с модернизацией инорормационно-библиотечной деятельности в республике в 2011 г. была внедрена новая информационная система «АИБС», разработанная отечественной фрирмой «Метрофрор», на основе фрормата каталогизации MARC21.

В 2013 году Агентством «Узстандарт» был 
утвержден Государственный стандарт Республики Узбекистан O'z DSt 2803:2013 «Система стандартов по информации, библиотечному и издательскому делу. Коммуникативный машиночитаемый фрормат UZMARC», разработанный на основе международного стандарта UNIMARC. В этой связи в 2015 г. Центром молодых программистов «BePRO» был разработан новый программный продукт для библиотеки - информационная система «IBS», поддерживающая фрормат UZMARC.

Сотрудники Национальной библиотеки в тесном сотрудничестве с программистами корейской компании «FutureNuri» приступили к разработке информационной системы, удовлетворяющей современным требованиям каталогизации.

C фревраля 2019 года была запущена новая информационная система Национальной библиотеки «UzNEL», являющейся интегрированной системой Национальной библиотеки и 14 инорормационно-библиотечных центров республики.

Система UZNEL обладает всем необходимым функционалом инорормационно-библиотечной работы: модуль «Комплектование», модуль «Каталогизация», модуль «Книговыдача» (включает также «Регистрацию пользователей»), модуль «Администратор» (или «Общий» модуль), кроме того система соединена с серверным хранилищем данных (более 20 серверов, SAN (Storage Area Network) хранилище объемом З0Тб и NAS (Network Attached Storage) хранилище с объемом 600 ТБ) для загрузки полнотекстовых электронных документов, в том числе оцифрованных библиотекой.

Все вышеперечисленные службы Национальной библиотеки Узбекистана выполняют одну общую задачу - это создание условий пользователям, имеющимся высоко-оснащённым технологичным оборудованием.

В 2018 г. на основе Постановления Президента Республики Узбекистан от 17 декабря 2013 года № ПП-2088 «О первоочередных мерах по реализации проекта «Национальная общеобразовательная электронная библиотека» при финансовом сотрудничестве с Фондом экономического развития и сотрудничества Республики Корея» начался новый этап автоматизации библиотеки. Для создания электронного читального зала была проведена реконструкция здания на первом этаже библиотеки общей площадью $350 \mathrm{~m}^{2}$ на 106 посадочных мест. В читальном зале имеется специальная зона для лиц с ограниченными возможностями, оснащенная специальными компьютерами для использования видеоматериалов. Также в читальном зале пользователям созданы условия для поиска книг в e-book фрормате и после оформления заказа читатели могут получить инфрормацию в электронной фрорме. Стоит вопрос, как будут развиваться в следующее 10-летие информационно-коммуникационные технологии в глобальном масштабе, в частности, в Национальной библиотеке и прикреплённых региональных информационно-библиотечных центрах Узбекистана на следующем этапе создания электронных библиотек. Эта тенденция связана с тем, что в будущем значительно сократится издание и выпуск печатной продукции, в связи с переходом на циорровые технологии и увеличением обращений к электронным ресурсам.

Сардор Холбоев - Ўзбекистон Миллий кутубхонаси Тармокларни маъмурийлаштириш ва сервер ускуналарини сақлаш хизмати I тоифали мутахасиси.

Муаллиф ахборот-кутубхона муассасалари ривожланиши ахборот технологиялари билан бевосита бовлиқлигини амалга оширилаётган лойихалар билан изохлайди. Мақолада Ўзбекистон Миллий кутубхонасида ахборот технологияларида сервер хизматини кўллаш тарихи 1999 йилда 80 Мб маълумотлар базасини сақ,лаш хажмига эга сервер билан бошлангани ва хозирги кунга келиб хизмат кўрсатиш қуввати 300 Тб ли турли мазлумотлар базасини ўз ичига қ,амраб олган сервер хизмати хақида батафсил сўз борган. Бу хизмат фаолияти нафақат Миллий кутубхона фойдаланувчилари учун балки, республикамиздаги йирик вилоят ахборот-кутубхона марказлари фойдаланувчиларига х,ам дастурий таъминот орқали ахборот етказиб бериш бўйича турли лойихаларни амалга оширган. Муаллиф хулоса ўрнида келажакда босма нашрлар уурнига ахборотни етказиб беришда рақамли технологияларнинг самарали усуллари жадаллик билан ривожланишида кутубхоналарда хизмат куррсатишни имкониятлари х,ам ўзгариб бориши далиллар билан келтирган.

\section{С фревраля}

2019 года была

запущена новая

инорормационная

система

Национальной

библиотеки

«UZNEL»,

являющейся

интегрированной

системой

Национальной

библиотеки и

14 инорормационно-

библиотечных

центров республики

Система соединена

с серверным

хранилищем данных (более 20 серверов, SAN (Storage Area

Net-work) хранилище объемом 30 Тб и NAS (Net-work Attached Storage) хранилище с объемом 600 ТБ) для загрузки полнотекстовых электронных документов, в том числе оцифрованных библиотекой 


\section{ПРОЦЕССОВ В ПСИХОЛОГИЧЕСКОМ РАЗВИТИИ И ЖИЗНИ ЧЕЛОВЕКА}

ЗНАЧЕНИЕ, ИНФОРМАЦИОННЫХ

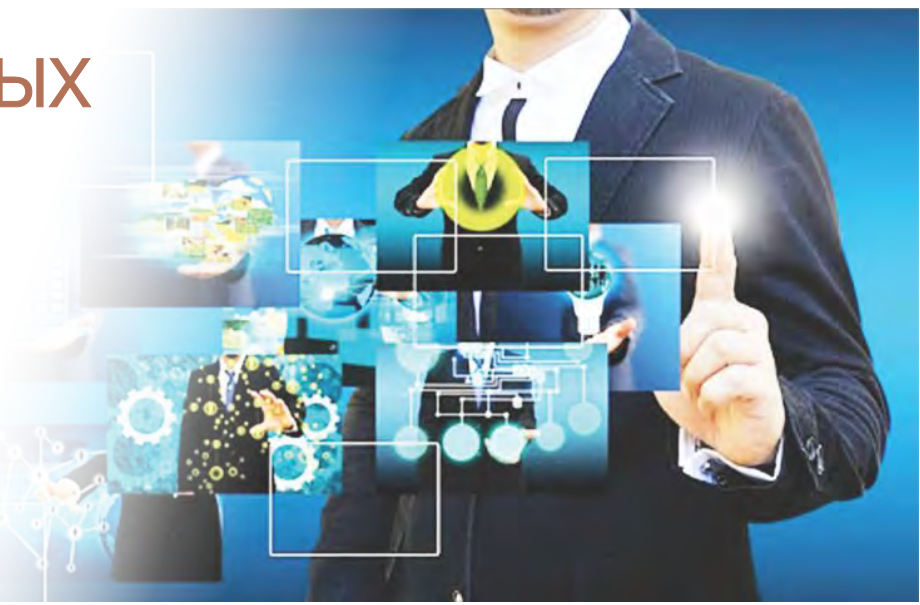

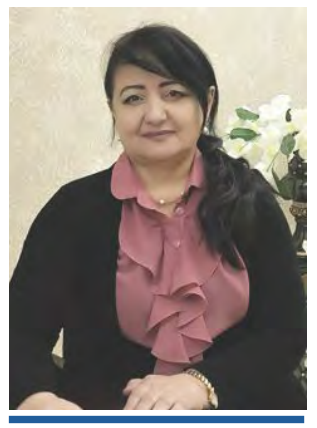

Лола Мухамедова,

Ассистент

Ташкентского Государственного

Аграрного университета

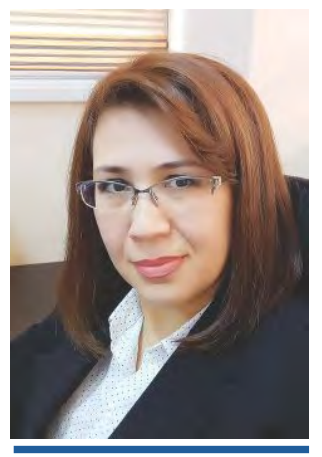

Муаззам Курбанова, директор ИРЦ,

старший

преподаватель

Ташкентского

Государственного

Аграрного университета

This article examines the individual's active behavior in difficult conditions for the process of adaptation to the information environment. At the same time, the role of the modern library is with awareness. The analysis of cognitive dissonance in order to reduce anxiety, conflict situations and increase the effectiveness of self-realization of the individual. The new information worldview takes into account the role of information processes in scientific and social progress, rethinks the importance of information, information processes and information technologies in human life and society.

Ключевые слова: «инорорма-ционное мировоззрение», социальный характер, знания, адаптация, психология, личность, гармония.

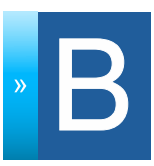
ажную роль в информационную эпоху играет в жизне образование, формирующее уних новые знания, умения, опыт деятельности. Эфрфективная адаптация к новой информационной среде зависит от многих фракторов, в том числе и от правильного мышления, психологической готовности человека к новым формам взаимоотношений, особенно социально-коммуникативным возможностям.

Образование способствует фрормированию нового целостного миропонимания и информационного мировоззрения, адекватного новой необходимости. Процессы адаптации человека к современному инорормационному обществу имеют преимущественно не биологический, а социальный характер, и осуществляются через построение культурной, над индивидуальной системы адаптации.

Диалектичность ситуации адаптационных процессов в том, что внешние воздействия среды приводят к внутреннему дисбалансу, который в свою очередь развивается в конфликты с окружающими людьми. Следовательно, адаптационные механизмы наиболее эффрективны при активном творческом изменении внутреннего содержания личности

- выработке новых фрорм поведения, овладении новых фрорм деятельности. Эти внутренние трансформации неизбежно отражаются на взаимоотношениях с окружающими людьми, иногда возможно и изменение социального статуса индивида. Подобный конструктивный подход к патологическим состояниям - это уже признак системного мировоззрения.

Таким образом, успешная адаптация, т.е. здоровье человека (физическое и психическое) неразрывно связаны с его мировоззрением. Мировоззрение, основанное на знании универсальных закономерностей и направленное на объединение с окружающим миром, позволяет человеку бескризисно преодолевать сложные переходные процессы в жизни, помогает выбирать наиболее эффрективные пути развития. В работах современных исследователей С.Г. Антоновой, К.К. Колина, И. А. Кузибецкого, Л.В. Нестеровой и др. уже появилось новое понятие «информационное мировоззрение». Новое информационное мировоззрение учитывает роль информационных процессов в научном и социальном прогрессе, переосмысливает значимость инорормации, информационных процессов и инорормационных технологий в жизни человека и общества.

Во всех областях деятельности особенностью современного общества является инновационная развития, которое признается единственным возможным путем дальнейшего развития.

Все необходимые материалы можно получит услугами навигации современной библиотеки. Для того, чтобы обеспечить новое ка- 
чество функционирования и развития необходимо новейшая информационно-коммуникационная технология интернета, что дает качественную услугу доступа пользователей к удаленным ресурсом библиотек.

Если личность при инновационном развития современного мира не успевает получать необходимые качественные материалы, постепенно наступает когнитивный диссонанс. (это несоответствии состояния того, что наблюдаешь тому, что у тебя в сознании).

Инорормационные перегрузки способны вызывать различные формы дезадаптации человека. В первую очередь это нарушение психологического равновесия человека, которое затем приводит к соматическим заболеваниям. Формы проявления психологической адаптации человека к окружающему миру могут быть различными:

\section{1) в виде различных фрорм психологичес- кой защиты; \\ 2) психосоматических заболеваний; \\ 3) психотических состояний.}

Может возникнуть проблема неуверенности в себе, она часто носит неосознанный характер и маскируется под другие проблемы: излишнюю тревожность, агрессивность, потерю вкуса к жизни и др. Например, человек начинает ощущать, что он недостаточно хорош, раз не справляется с современной информационной техникой, не может разобраться в новых технологиях, успеть ознакомиться со всеми литературными, профессиональными новинками. В процессе преодоления человеком подобной ситуации, чтобы выглядеть достойно в глазах окружающих, не вызывать осуждения, человек использует приобретенный на предшествующих этапах опыт или открывает принципиально новые способы поведения и решения сложных задач, моделирует новые программы и планы внутрипсихических процессов, фрормирует новые связи, для преодоления возникших ситуаций.

Адаптация к новым условиям, переживание периода неопределенности неизбежно влечет за собой психологический стресс у индивида, так называемый стресс адаптации. Состояние неопределенности, тревожности может стимулировать адаптационные процессы, так как индивид осознанно и неосознанно стремится вернуть комфрортное самочувствие. Но оно же может стать причиной дезорганизованного поведения и, позже, к психосоматическим расстройствам.

У личности существует фрормированная система ценностей и моральных принципов представлений о мире. Личность чувствует себя отлично в ситуациях, когда она понимает что происходит вокруг. В противном случае возникает тревога и не приятие действительности. Если у вас есть согласованность между знаниями, принципами и действием ваша психика считается адаптированной, если нет, то в головном мозге происходит тряска, который вынуждает в выходу из зоны комфорта. Если когнитивный диссонанс слишком сильный, могут возникнуть стресс, и даже депрессия.

Человек по мере информированности корректирует свои принципы, знания, понятия и меняет их, меняется поведения, то есть идет процесс самонастройки к современному инновационному миру благодаря услугам современной библиотеки.

Давайте заглянем в прошлое. Раньше доступ к книгам для простого рабочего человека были роскошью. Библиотеки были только в богатых домах и литература в них была в основном специфическая. А сейчас? Открытые просторные залы, множество стеллажей с книгами, электронные залы с компьютерами, телевизоры, проекторы, акустическое оборудование для мероприятий.

Если инфрормация вызывает антигармонию личность от этой ситуации максимально дистанцируется. Поэтому в первую очередь необходимо решить вопросы инновационность деятельности библиотек, к которому уделяется очень много внимании.

Возрастающая информатизация общества особенно кардинально повлияло на состояние чтения. В настоящее время соперником библиотеки является Интернет.

Происходит отток читателей из библиотек, в том числе детского и подросткового.

Существует очень много гипотез, что привлечения в библиотеку читателей нового поколения возможно при активном использовании современных инфрормационно- коммуникационных технологии с использованием ресурсов Интернет.

Основные понятия инновации: в жизнедеятельности любой организации меняется за счет постоянного появления новых технологий, который дает рост и качество профрессиональной деятельности. Не смотря на того, что очень много техники внедрено в производство для улучшения качество производство и качество жизни (люди раньше часами, днями, месяцами томительно выполняли трудную работу для выполнения планов или
Человек по мере инорормированност и корректирует свои принципы, знания, понятия и меняет их, меняется поведения, то есть идет процесс самонастройки к современному инновационному миру благодаря услугам современной библиотеки

Существует очень много гипотез, что привлечения в библиотеку читателей нового поколения возможно при активном использовании современных инорормационнокоммуникационных технологии с использованием ресурсов Интернет 
В настоящее время в системе «Человек Природа Общество»

в адаптационной способности человека можно выделить биологическую, социальную и психологическую составляющие

Необходимо отметить, что в зависимости от индивидуально психологических свойств личности адаптационный

процесс может протекать либо в активноцеленаправленной, либо в пассивноприспособительно й фрорме заказов), психологическое состояние людей становиться хуже, чем раньше. Если не учесть человеческий фрактор, что люди имеют право на счастливую жизнь и они являются биологическими организмоми на что влияет очень много фракторов, который приводит в дальнейшем срывам, конфрликтом особенно чрезмерные нарузки производство и отдалении от семьи, но в настоящее время во многих отраслях в жизнь человека очень много инновации (новшество) введено, но состояния людей по отношении психики и здоровья все хуже ихуже (статистика 2019 года)

По статистики идет рост не только качество жизни, но и рост цевилизационных болезней онкологии, ИБС, аллергия, сахарный диабет, цирроз печени, СПИД, бесплодия и высокая смертность. Растет бездомность, алкоголизм, наркомания, проституция.

Все это возникает в результате невозможности самостоятельно решить проблемы.

Для того, чтобы получить инфрормации об уровни жизни мы обратимся к сайту Numbeo, который ежегодно публикует рейтинг уровня жизни в странах мира. Сюда входит 71 стран, где оценивается по следующим параметром.

- Покупательная способность граждан;

- Уровень загрязнения окружающей среды;

- климат;

- безопасность;

- уровень здравоохранения;

- стоимость жизни;

- стоимость недвижимости;

- временные затраты на поездки.

Социологи мира считают, что материальное благосостояния - это не самый важный фрактор, что жизнь хороша или плоха в отдельно взятой стране помимо основных благ, это доступ жилья и продовольствия, образования, здравоохранения, занятость, которая будет поддерживать благосостояния, понятия «уровень жизни» также включает и нематериальные активы такие как безопасность, рабочих мест, политическая стабильность, свобода личности и качество окружающей среды. В этой списке Узбекистана пока нет, Казахстан находится 69 месте после Вьетнама, на первом месте Денмарк Королевство Дании, где царит Средневековье и романтизм, более того человек оказавшись в этом государстве, полностью погружается в мир сказки. Согласно статистики Дания самая дорогостоящая страна. По статистики считается самые счастливые люди это датчане.

Таким образом, человеку для благополуч- ной жизнедеятельности следует неизменно вырабатывать социальные черты и психологические качества в собственной личности. Поскольку уровень социально-психологических параметров личности оказывает непосредственное воздействие на результативность деятельности.

В настоящее время в системе «Человек Природа - Общество» в адаптационной способности человека можно выделить биологическую, социальную и психологическую составляющие. Процесс адаптации определяет кроме самого существования еще и возможности человека вести полноценную, эфррективную жизнь, находя необходимые «ответы» на «вызовы» окружающей его природной и социокультурной среды. Под воздействием новых вызовов информационной среды нарушается равновесное состояние организма: начиная с психологических отклонений, через невротические реакции к развитию телесных патологий - болезней. Наиболее тяжелыми последствиями могут быть дезорганизация, нарушение целостности личности, разрушение психической защиты личности и др.

Необходимо отметить, что в зависимости от индивидуально психологических свойств личности адаптационный процесс может протекать либо в активно-целенаправленной, либо в пассивно-приспособительной орорме. Таким образом, социально-психологическая адаптированность следует определять как «такое состояние взаимоотношений личности и группы, когда личность без длительных внешних и внутренних конфрликтов продуктивно выполняет свою ведущую деятельность, удовлетворяет свои основные социогенные потребности, в полной мере идет навстречу тем ролевым ожиданиям, которые предъявляет к ней эталонная группа, переживает состояния самоутверждения и свободного выражения своих творческих способностей, находиться в гармонии с самим собой и окружающем миром, что дает реализовать способности и внутреннее потенциалы личности.

Из сказанного можно сделать вывод, что развития библиотек происходит стремительно. Способность человека адаптироваться к изменениям окружающей среды, взаимодействуя с ней основе биологической, психологической и социальной сущности, тесно связана с понятием здоровья человека. И многие исследователи считают, что «адаптационные возможности организма» мо- 
гут рассматриваться как мера здоровья, как мера защиты от болезни»Для того чтобы, каждый индивидуальный личность мог получить качественную информацию и имел базу реальных услуг, необходимо единое инфрормационное пространства инновационное совершенствование библиотечной деятельности. Электронная среда, с одной стороны, помогает библиотекарю ориентироваться в литературном пространстве, с другой - библиотекарь сам выступает навигатором в книжном мире. Успешными, становятся только те из них, которые внедряют в свою практику инновационные проекты, находят новые способы и методы обслуживания. Как считают ведущие специалисты страны, инновационный путь развития библиотек «единственный путь, обеспечивающий поступательное развитие библиотечного дела». С точки зрения управления библиотечным делом, инновация - это целенаправленно проводимые изменения во всех сорерах и на любом участке библиотечной деятельности, для адаптации к требованиям внешней среды с целью достижения долгосрочной эффективности функционирования. Сегодня библиотеки применяют новые фрормы работы (электронные выставки, виртуальные экскурсии и презентации, чат-конфреренции, транслирование библиотечных мероприятий онлайн, обзоры сетевых ресурсов), создают новые типы ресурсов (виртуальный выставочный зал), используя для этого RRS-рассылки, социальные сети, фрото- и видео сервисы. С помощью Интернета расширяется аудитория при информировании о библиотечных услугах. Читатели могут посетить виртуальные мероприятия, получив наглядное представление об имеющихся изданиях и услугах библиотек. С помощью сетевых технологий (мобильные, фрото-, видео-сервисы, электронные библиотечные системы) библиотеки могут информировать читателей о своей деятельности, анализировать имеющиеся в фонде ресурсы, организовывать рекламные компании, изучать запросы потребителей инорормационных услуг. Все вышеизложенное позволяет сделать вывод о том, что современные библиотеки, находящиеся на этапе внедрения новых информационных технологий, обладают огромным инновационным потенциалом и уже в недалеком будущем это сулит полную перестройку самих принципов организации библиотечного обслуживания. Развития страны непосредственно связанно психологическом развитием личности, гармонично вписываясь в библиотечно-информационную систему через Интернет-пространство, расширяет этим круг своих информационных баз, и в первую очередь, среди молодежи.

\section{Список литературы:}

1. «Адаптация личности в современном мире» межвузовский сборник научных трудов выпуск 3,2011 г.

2. «Теория когнитивного диссонанса» книга Леон Фестингер, Анистратенко перевод на русский язык, 2018 г.

3. Библиотечное дело: терминолог. словарь.-М.: РГБ, 1997.-С. 45.

4. Камалетдинов Р.К Автоматизированные библиотечные информационные системы как средство освоения и внедрения ИКТ // Р.К Камалетдинов // Вестник Казанского ГУКИ. - 2012. - № 4. - С. 152-154.

5. Гусева Е. Всероссийский конкурс библиотечных инноваций: идеи и технологии /Е.Н. Гусева // Медиатека и Мир. - 2013. - № 3. - С. 6-8.

6. Гусева Е.Н. Инновация как стратегия, фактор и условие развития библиотек/Е.Н. Гусева //Школьная библиотека. -

Лола Мухамедова - Тошкент Іавлат Аграр ениверситетини жисмоний тарбия ва спорт кафедраси ассисенти.

Ушбу мақола мураккаб шароитларда шахснинг фаол хатти-х,аракати ахборот мух, итига мослашиш жараёни учун мухим ах,амиятга эга. Шу билан бирга, ахборот олишда замонавий кутубхонанинг роли кўриб чиилади. Ихтилофли вазиятларни камайтириш ва шахсни ўз-уззини англаш самарадорлигини ошириш учун когнитив диссонанс тахлиллари уттказилди. Янги ахборот дунёқараши илмий ва ижтимоий тарақққиётда ахборот жараёнларининг ролини хисобга олади, инсон ва жамият хаётида ахборот, ахборот жараёнлари ва ахборот технологияларининг ахамиятини қайта кўриб чиқади. Масофадан ишлашда янги информасион-коммуникатив технологиялардан фойдаланишда сифатли библиотека маълумотларидан фойдаланиш усуллари кўриб чиқилади. Психологик мувозанатни шах,сни соматис х,латига таъсири ва муваффииятларга эъришиш. Ахборат-технология янгиликларига онсон ва тез мослашиш. Ахборат маълумотлар баъзасидан унумли ва самарали фойдаланишни дунё рейтинг хайёт тарзига таъсири куцриб чилади. Cuфатли хайёт тарзи шах,сни ах,борат-маълумот баъзасидан қ,ай даражада фойдаланишига бовликлигини кууриб чикилади.

\section{Электронная}

среда, с одной

стороны, помогает

библиотекарю

ориентироваться

в литературном

пространстве,

с другой -

библиотекарь сам

выступает

навигатором

в книжном мире

C точки зрения

управления

библиотечным делом,

инновация - это

целенаправленно

проводимые

изменения во всех

сорерах и

на любом участке

библиотечной

деятельности,

для адаптации

к требованиям

внешней среды

с целью достижения

долгосрочной

эфроективности

фрункционирования 


\section{«ЎЗБЕК» ВА «ЎЗБЕКИСТОН» АТАМАЛАРИ ЁЗМА МАНБАЛАРДА}

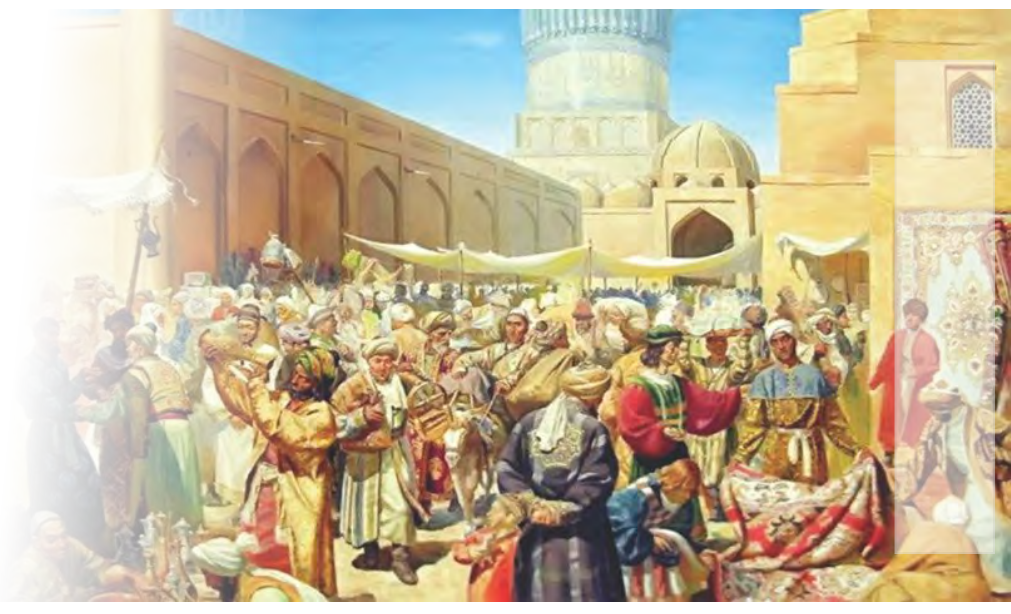

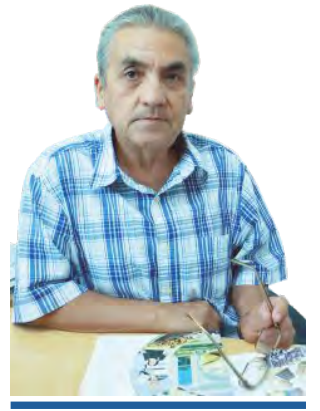

Шамсиддин

Камолиддин, тарих франлари доктори, профрессор

«уัзбекистон» атамаси тарихий илдизларга эга

бўлиб, бутун

Ўрта Осиё минтақасининг тарихий

номларидан бири бўлган. «Ўзбекистон»

атамаси манбаларда илк бор XIV асрда,

тарихий

хариталарда эса

XVI асрда муомалага кирган

The article discusses the use of the term "Uzbek" and the toponym "Uzbekistan" in medieval written sources. The name Uzbek is first encountered in the sources of the 12th century; this name was borne by some of the Turkic rulers of the Near and Middle East. The origin of the toponym Uzbekistan is associated with the name of the ruler of the Golden Horde, Uzbekkhan. In the fourteenth century. the name of Uzbekistan was understood as the Golden Horde. In the fifteenth century. after the collapse of the Golden Horde into several khanates, the name Uzbekistan was attached to the Uzbek Ulus, i.e. the state of nomadic Uzbeks, formed in the eastern part of the Golden Horde. From the beginning. XVI century the toponym Uzbekistan began to be applied to the whole of Central Asia, on the territory of which the state of the Shaybanids was formed. This name was used as a synonym for the place names Turan and Turkestan up to 1865, when Central Asia was conquered by the Russian Empire. Ba-sed on these data, we have every reason to believe that the toponym Uzbekistan, used for 365 years (from the beginning of the 16th century to 1965) in relation to the whole of Central Asia, was one of the historical names of the region.

Keywords: Central Asia, Turan, Turkistan, Uzbekistan, the Uzbeks, the Turks, the Golden Horde, the Uzbek Ulus, the Shaybanids.

Шўролар даври тарихшунослигида «Ўзбекистон» атамаси 1924 йилда коммунистлар томонидан ўтказилган «миллий-худудий чегараланиш» гача мавжуд бўлмаган, деган хато орикр хукмрон эди. Хозирги кунда «конструктивизм» жамиятшунослик назарияси тарафдорлари хам «Ўзбекистон» атамаси 1924 йилда янги уцзбек миллатини «ясаш» мақсадида муомалага киритилган, унга қадар эса бу атама мавжуд бўлмаган, деган фрикрни илгари сурадилар. Менинг тадқиқотларим шуни кўрсатадики, «Ўзбекистон» атамаси тарихий илдизларга эга бўлиб, бутун Ўрта Осиё минтақасининг тарихий номларидан бири бўлган. «Ўзбекистон» атамаси манбаларда илк бор XIV асрда, тарихий хариталарда эса XVI acpда муомалага кирган. XIV асрда бу атама Олтин Ўрда, XV асрда - Дашти Қипчоқдаги Ўзбек Улуси, XVI - XIX асрларда эса Ўрта Осиёга нисбатан қўлланилган.

«Ўзбекистон» атамасининг келиб чиқиши «Ўзбек» исми билан боғлиқ бўлиб, бу исм оғуз/ғуз/уз ва бек сўз ларидан ташкил топган, ва «ўғузлар беги» маъносини англатади. «Ўзбек» исми манбаларда илк бор XII аср да қайд этилган - Хамадон шахри хукмдори Сурсуқнинг лашкарбошиларидан бири (амир алжайш) Ўзбек 1115-1116 йилларда Мосул хокими бўлган [Усама ибн Мункыз: 135]. Табризда хукм сурган Илдегизийлар сулоласининг охирги хукмдори Музафорариддин (12101225 йилларда хукм сурган) нинг исми хам Ўзбек бўлган [Рашид ад-Дин I (2): 159, 186, 193]. Хоразмшох Жалол ад-Диннинг Афрғонистондаги харбий қўмондони Жахон Пахлавон Ўзбек Тоий бўлган [ан-Насави: 134-136, 267].

\section{«Ўзбек вилояти» ёки «ўзбекистон»}

Олтин Ўрда маъносида (XIV аср)

«Ўзбекистон» атамаси эса Жўчи Улуси, яъни Олтин Ўрда хукмдори Султон Ғиёсиддин Мухаммад Ўзбекхон (тахм. 1283 - 1341) билан боғлиқ. 712/1312-13 йилда у Хоразмдан келган бекларбеги Қутлуғ-Темур ва мусулмонлар ёрдамида тахтга келди, 720/1320-21 йилда эса ўзи хам расман ислом динини қабул қилди. Бунда унга Ахмад Ясавийнинг устози бўлмиш Боб Арслоннинг авлоди Зангиота ва унинг издоши Сайидота кўмакчи бўлганлар. Ўзбекхон хукмронлиги даврида Олтин Ўрда 
ўз даврининг энг қудратли ва нуффузли давлатларидан бирига айланди. Шунинг учун XIV - XV асрларда ёзилган манбаларда Олтин Ўрда «Ўзбекистон», яъни Ўзбекхон мамлакати деб аталган. XIV асрнинг иккинчи ярми XV асрнинг биринчи ярмида турк тилида ёзилган адабиётда, хусусан, шоир Лутфийнинг «Гули Навруз» асарида «Ўзбек» мамлакати ўша даврнинг энг қудратли давлатлари қаторида тилга олинган:

Гох Чин хубларини суззладилар,

Гох Ўзбек дин парилар кўзладилар,

Гохўғдилар Хотан зеболарини,

Замин-е Румнинграъноларини.

[Фазылов 2006: 61 (6в7)].

Муиниддин Натанзийнинг «Мунтахаб аттаворих-и Муиний» («Муиний тарихлари танланмаси») асарида Итил, яъни Волга дарёси бўйларидаги Ўзбек Улуси қайд этилган [Haтанзий: 100]. Фасих ал-Хавафийнинг «Мужмал-и Фасихий» асарида 1335 йил воқеалари баёнида Олтин Ўрданинг нуфузли амирларидан бири Қутлуғ Тимур «Ўзбек давлатининг таянчи» деб аталган [ал-Хавафи: 59, 66]. Шарафриддин Али Яздий «Зафрарнома» асарида: «Шундан кейин Сохиб Қирон Жете ва Ўзбек [хонлари] дан келган элчиларни қабул қилди ва уларга олтин совғалар бериб, уларни ўз хонлари хузурига юборди», деб ёзади [Йазди: 221]. Низомиддин Шомий уузининг «Зафрарнома» асарида Ўзбек мамлакати хақида шундай ёзади: «Хоразмдан шимолда жойлашган вилоят Ўзбек деб аталган» [Шомий: 103]. «Урусхон (1361-1375) Ўзбек вилоятининг хукмдори эди» [Шомий: 59]. «Амир Сохиб Қирон Карминага етиб келганда, душман қочди ва Ўзбек вилоятига кетиб, Урусхон саройида панох топди» [Шомий: 99]. «Ўзбек вилоятидан одам келди» [Шомий: 200]. «Амир Сохиб Қирон Ўзбек вилоятига юрди» [Шомий: 152]. «Ўзбек вилоятига юриш» [Шомий: 229]. «Тимур Қутлуғ Хон ажалини Ўзбек вилоятида топди» [Шомий: 277]. Туркистонлик ўзбек шоири Шоир Хукмий 977/1569-70 йилда ўзининг Эронда фрорс тилида ёзилган «Шахристон» номли геограсрик шеърий асарида шундай ёзади: «Ўзбеклар мамлакати ёки Ўзбекистон Румдан шарқда Чингача, шимолда эса Булғор ва Рус мамлакатигача чўзилган» [Бартольд 1973: 410 - 411]. Абдураззоқ Самарқандийнинг «Матлаи саъдайн ва мажмаи бахрайн» асарида 1410 йил воқеалари баёнида «Дашти Қипчоқ ва Ўзбек мамлакатлари», «Дашти Қипчоқ тарафдаги Ўзбек вилояти» қайд этилган [Самарқандий I: 168, 453].

Мирзо Улуғбек «Тарихи арба'а улус» («Тўрт улус тарихи») асарида ёзишича, «Султон Мухаммад Ўзбекхон Мовароуннахрга келганда, махаллий одамлар унинг одамларидан: «Бу келган одам ким?», деб сўрадилар. Уларнинг сардори ва подшохи Ўзбекхон бўлгани учун уларни «ўзбек» деб атар эдилар. Шу сабабли ўша замондан бошлаб келган кишилар «ўзбек» деб атала бошлади. Қолиб кетган кишилар эса «қалмоқ» бўлдилар [Улуғбек: 226].

Махмуд ибн Вали «Бахр ал-асрор фи маноқиб ал-ахёр» («Хайрлиларнинг фразилатлари хақида сирлар денгизи») асарида шундай ёзади: «Туркистон ахли хар бир даврда турли номлар билан аталган. Тур ибн Ёфас давридан Моғулхон давригача бу мамлакат ахли «турклар» деб аталган. Моғулхон тахтга ўтиргандан кейин бу мамлакатда яшовчи барча қабилалар «моғуллар» деб аталган. Туркистон узра Ўзбекхон байроғи кўтарилгандан кейин хозирга қадар бу мамлакат ахли «ўзбеклар» деб аталади. Лекин олис мамлакатларда Туроннинг барча ахолиси олдингидек «турк» деб аталади [Махмуд ибн Вали: 32].

«Ўзбек вилояти» ёки «Ўзбекистон»

Ўзбек Улуси маъносида (XV аср)

Тўхтамишхон (1380-1395 йилларда Олтин Ўрда хони, 1396-1406 йилларда Туман хони) Амир Темурдан бир неча бор мағлубиятга учрагандан кейин (1389, 1391, 1395, 1397 йилларда) Олтин Ўрда давлати инқирозга учрай бошлади ва аста-секин алохида хонликларга парчаланиб кетди. Бунинг оқибатида рус князлари (Иван Грознийдан бошлаб) кучая бошлади ва бирин-кетин ўзбек-татар хонликларини босиб олди - 1552 йилда Қозон, 1556 йилда Аштархон, 1598 йилда Сибир хонликлари, XVII асрда Нўғай ўрдаси, 1783 йилда эса Қрим хонлиги руслар томонидан босиб олинди. Русларга бўйсунмай мустақиллигини сақлаб қолган ягона ўзбек хонлиги Евросиёнинг шарқий қисмида жойлашган, шу жумладан, Марказий Осиёнинг шимолий қисмини ўз ичига олган Ўзбек Улуси эди [Ахмедов 1972]. Шунинг учун XV аср манбаларида Ўзбек вилояти ёки Ўзбекистон деганда ана шу Ўзбек Улуси назарда тутилган.

Фазлуллох Исорахонийнинг «Мехмоннома-и Бухоро» («Бухоролик мехмоннинг хотиралари») асарида шундай ёзилган: «3 та қабила ўзбекларга мансуб бўлган... Улардан бири - Шайбонийлар бўлиб, уларнинг хони Шайбонийхон эди. Иккинчи қабила - қозоқлар бўлиб, улар куч-қудрати ва довюраклиги билан дунёга машхурдир. Учинчи қабила - манғитлар бўлиб, улардан Аштархон хукмдорла-
XIV-XV асрларда

ёзилган

манбаларда Олтин

Ўрда «Ўзбекистон»,

яъни Ўзбекхон

мамлакати деб

аталган.

XIV асрнинг

иккинчи ярми -

$\mathrm{XV}$ асрнинг

биринчи ярмида

турк тилида ёзилган адабиётда, хусусан, шоир Лутоиийнинг

«Гули Навруз»

асарида «Ўзбек»

мамлакати ўша

даврнинг

энг қудратли

давлатлари

қаторида тилга

олинган

«Туркистон ахли хар бир даврда турли номлар билан аталган.

Тур ибн Ёфрас давридан Моғулхон давригача

бу мамлакат ахли

«турклар» деб

аталган.

Моғулхон тахтга

ўтиргандан кейин

бу мамлакатда

яшовчи барча

қабилалар

«моғуллар» деб

аталган.

Туркистон узра

Узбекхон байроғи

кўтарилгандан

кейин хозирга қадар

бу мамлакат ахли

«ўзбеклар» деб

аталади 
Ўзбекларнинг чегаралари бир тарафрдан уммон

билан, бошқа

тарафдан эса Туркистон билан, учинчи тарафдан Дарбанд билан, тууртинчи тарафдан

Хоразм билан,

бешинчи тарафдан

эса, Астробод

билан чегарадош.

Бу ерларнинг

хаммаси

ўзбекларнинг ёзги

ва қишги кўчиб юриш ерларидир»

1601 йилда

Шайбонийларнинг

ўрнига

Аштархонийлар

сулоласи

хокимиятга келиб,

1757 йилга қадар

хукм сурди.

Шу тариқа

«Ўзбекистон»

атамаси хам

ўзбеклар билан

бирга

Мовароуннахр, яъни Ўрта Осиёга кўчиб келди ри чиққан. Ўзбекларнинг чегаралари бир тарафдан уммон билан, бошқа тарафдан эса Туркистон билан, учинчи тарафдан Дарбанд билан, тўртинчи тарафдан Хоразм билан, бешинчи тарафрдан эса, Астробод билан чегарадош. Бу ерларнинг хаммаси ўзбекларнинг ёзги ва қишги кўчиб юриш ерларидир» [Исфрахани:62].

Мирза Мухаммад Хайдарнинг «Тарихи Рашидий» асарида ёзилишича, «Ўзбекистонга Абу-л-Хайр олдига турли қабилалар келди. Қозоқлар Ўзбекистоннинг асосий қисми устидан ўз хокимиятини ўрнатдилар» [Хайдар: 45P - 46А]. «Тубра ўқимаган одам эди, у хеч қачон хоқонларга хизмат қилмаган эди. У хар доим вақтини Мўғулистон ва Ўзбекистон даштларида ўтказар эди. У чегараларни қўриқловчи қазақ бўлган ва хеч қачон Амир даражасига кўтарилмаган» [Хайдар: 169A]. «Кўкча Тенгиз (Балхаш) кўли Мўғулистонни Ўзбекистондан ажратиб туради. Қиш келиб Кўкча Тенгиз усти муз билан қопланганда, ўзбеклар муз устидан юриб Мўғулистонга келадилар. Бу кўлдан бир дарё (Волга) бошланиб, Ўзбекистон ерларидан оқиб ўтади ва Қулзум денгизи, яъни Каспий денгизига қуйилади. Бу дарё Атил деб аталади, Ўзбеклар эса, уни Идил дейдилар» [Хайдар: 237А]. «Султон Нигорхоним деди: «Мен қариб қолдим ва Ўзбекистон даштларида кўчманчилик хаёт тарзи олиб боришга кучим йўқ». «Рашидиддин Моғулистонда қолди, Тохирхон эса Ўзбекистонда [хукм сурди]» [Хайдар: 245- А].

Амир Темур тузукларида ўзбеклар ва Ўзбекистон хақида шундай ёзилган: «Мовароуннахрда Ўзбекия [жамоаси] нинг жиноятлари ва зулмлари кўпайиб кетди. .... Мен зудлик билан ўзбеклар жамоасига хужум қилишим керак [Темур тузуклари: 28]. Мамлакатнинг уламо ва шайхлари ўзбеклар жамоасини йўқ қилиш ва хайдаб чиқариш хақида фратво бердилар [Темур тузуклари:29].

\section{«Ўзбекистон» Ўрта Осиё минтақаси маъносида (XVI - XIX асрлар)}

1500 йилда Ўзбек Улуси хукмдори Шайбонийхон Мовароуннахрга келиб, Темурийлардан хокимиятни тортиб олди. Дашти Қипчоқда хокимиятсиз қолган бошқа Чингизийлар, яъни ўзбек-татар хукмдорлари ва аслзодалари хам Шайбонийлар давлати (1500-1601) да панох топдилар. 1601 йилда эса Шайбонийларнинг ўрнига Аштархонийлар сулоласи хокимиятга келиб, 1757 йилга қадар хукм сурди. Шу тариқа «Ўзбекистон» атамаси хам ўзбеклар билан бирга Мовароуннахр, яъни Ўр- та Осиёга кўчиб келди. Шунинг учун XVI - XIX асрнинг биринчи ярмида ёзилган манбаларда Ўрта Осиё минтақаси «Ўзбекистон» деб аталган. Хусусан, Сафавийлар сулоласига мансуб Эрон шохи Тахмасп I (1524-1576) Mовароуннахрда жойлашган Шайбонийлар давлатини «Ўзбекистон» деб атаган [Кляшторный, Султонов 2004: 328]. 1562 йилда испан тарихчиси Гарсиа да Орта (Garsia da Orta) Ўрта Осиёда жойлашган «Ўзбек мамлакати» хақида сўз юритган [Berthold 1919: 346, 550].

Бухоро шахрида яшаган икки тиллик ўзбек шоири Турди Фароғий (тахм. 1640 - 1699) ўзининг бир шеърида шундай ёзади:

Тор кўнгуллик беклар, ман-ман деманг, кенглик қилинг,

Тўссон икки бовли Ўзбек юртидур, тенглик қилинг [Турди: 13].

Дурахд-у тангчашм-у бесар-у Яъжужваж, Мухталиср мазхаб гурухи Ўзбекистондур бу мулк.

Таржимаси:

[Одамлари] ишончсиздир, кўзлари қисиқ, калласи йуқ, худди Яъжуж сингари,

Турли мазхаб гурухларга [булинган] Ўзбекистондур бу мулк) [Турди:14].

Бобурийлар сулоласига мансуб султон Мyйиддин Аврангзеб Оламгир I (1068 - 1118/1658 - 1707 йилларда хукм сурган) хузурига элчи бўлиб келган ва унинг Дехлидаги саройида бир муддат яшаган фрранцуз элчиси Франсуа Берньенинг ёзишича, «Ўзбек Татарлари, яъни Самарқанд ва Балх хонлари, Аврангзеб хузурига ўз элчиларини юборишга қарор қилдилар» [Бернье: 128]. «Аврангзеб улар юборган совғаларни келтиришни буюрди... булар мевалар эди: шафтоли, олма, узум, қовун - бу меваларни Дехли ахолиси йил буйи ер эди, улар, асосан, Ўзбекистондан келтирилар эди» [Бернье:129]. «Мен элчилардан уларнинг мамлакати хақида маълумот олишни истадим, лекин улар шунчалик билимсиз эдиларки, хатто ўзларининг Узбекия мамлакатининг чегараларини хам билмас эканлар» [Бернье: 130].

1835 - 1836 йилларда Бухорога келган рус харбий айғоқчиси И.В.Виткевич ўзининг сафар хисоботида шундай ёзади: «Бухоро шахрида бухороликлардан ташқари жуда кўп яхудийлар яшайди, сен у ерда бутун Ўзбекистон ёки Турондан келган одамларни учратишинг мумкин» [Виткевич 1983: 104].

Шундай қилиб, «Ўзбек» исми туркларда илк бор XII-XIII асрларда қайд этилган бўлиб, унинг келиб чиқиши оғуз/ғуз/уз ва бек сўзлари 
билан боғлиқ ва «ўғузлар беги» маъносини англатади. «Ўзбекистон» атамаси Олтин Ўрда хукмдори Ўзбекхон билан боғлиқ бўлиб, XIV асрда бу атама Олтин Ўрда давлатига нисбатан қўлланилган. XV асрда Олтин Ўрда хонликларга парчаланиб кетгандан кейин «Ўзбек вилояти» ёки «Ўзбекистон» атамаси Дашти Қипчоқнинг шарқий қисмидаги Ўзбек Улусига нисбатан қўлланилган. XVI асрда ўзбеклар Мовароуннахрни эгаллагандан кейин то руслар босқинига қадар Ўзбекистон атамаси бутун Ўрта Осиё минтақасига нисбатан қўлланилган. Ўша давр тарихий географиясида «Ўзбекистон» атамаси Турон ва Туркистон тарихий атамалари билан тафовутда бўлмай, аксинча, улар бирга маънодош ном сифратида ишлатилган. Демак, «Ўзбекистон» атамаси бутун Ўрта Осиё минтақасининг тарихий номларидан бири бўлган деб хисоблашга тўла асос бор. Чунки жахон тарихий географиясида бу атама 1865 йил, яъни руслар босқинига қадар 365 йил давомида Турон ва Туркистон атамалари сингари бутун Ўрта Осиё минтақасига нисбатан макротопоним сифратида ишлатилган.

\section{Фойдаланилган адабиётлар, манбалар}

Бернье - Франсуа Бернье. История последних политических переворотов в государстве Великого могола/Предисловие А.Пронина, перевод с франиузского Б.Жуковецкого и М.Томара. М.;Л.:Соцэкгиз, 1936.

Махмуд ибн Вали - Махмуд ибн Вали. Море тайн относительно доблестей благородных (География) указатели Б.А.Ахмедова. Ташкент: Фан, 1977.

Натанзий - Муиниддин Натанзий. Мунтахаб ут-таворихи Муиний (Муиний тарихлари танланмаси) / Форс тилидан таржима, сўз боши ва изохлар муаллифи F.Каримий. Тошкент: O'zbekiston, 2011.

Рашид ад-Дин - Рашид ад-Дин. Сборник летописей / Пер. О.И.Смирновой. Т. 1 (2). М.: Изд-во АН СССР, 1952.

Самаркандий - Абдураззок Самаркандий. Матлаи саъдайн ва мажмаи бахрайн / Форс тожик тилидан таржима, 1-2 кисм. Тошкент: O'zbekiston, 2008.

Темур тузуклари - Уложение Темура / Пер. с перс. Х.Кароматова, под ред. Б.Ахмедова. Предисловие, примечания и комментарии Б.Ахмедова. Т.: Изд-во литры и искус-ства, 1999.

Улувбек-М. Улувбек. Тўрт улус та-рихи / Форс тилидан Б.Ах,медов, Н.Норкулов ва М.Хасаний таржимаси. Т.: Чўлпон, 1994.

Усама ибн Мункыз - Усама ибн Мункыз. Книга издания/Пер. М.А.Салье. М.: ИВЛ, 1958.

ал-Хавафи - Фасих ал-Хавафи. Муджмали Фасихи (Фасихов свод) / Пер. Д.Ю.Юсуповой. Ташкент: Фан, 1980.

Хайдар - Мирза Мухаммад Хайдар. Таърих-и Рашиди / Введение, перевод с перс. А.Урунбаева, Р.П.Джалиловой, Л.М.Епифановой. Примечания и указатели Р.П.Джалиловой и Л.М.Епифановой. Т.: Фан, 1996.

Шомий - Низомиддин Шомий. Зафарнома. Форс тилидан уцгирувчи Ю.Хакимжонов. Таржимани қайта ишлаб нашрга тайёрловчи ва масъул мухаррир А.Ўринбоев. тошкент: O'zbekiston, 1996.

\section{Илмий адабиётлар}

Ахмедов 1972 - Ахмедов Б.А. Государство кочевых узбеков. Ташкент: Фан, 1972.

Бартольд 1973 - Бартольд В.В. Отчет о ко-мандировке в Западную Европу // Соч., $m$. 8. М.: Наука, 1973. С. 397-412.

Виткевич 1983 - Записки о Бухарском ханстве (Отчеты П.И.Демезона и И.В. Виткевича) / Отв. ред. Н.А.Халфин. Вступительная статья и комментарии В.Г.Воловникова и Н.А.Халфина. М.: Наука, 1983.

Фазылов 2006 - Фазылов Э.И. Будапештская рукопись «Гуль и Навруз» Лютфи /Под ред.А.Н.Кононова. Ташкент, 2006.

Berthold 1919 - Laufer Berthold. Sino-Iranica. Chinese contribution to the history of civilization in ancient Iran. Chicago, 1919.

Шамсиддин Камолиддин - доктор исторических наук, профессор.

В статье рассматривается вопрос об употреблении термина «Узбек» и топонима «Узбекистан» в средневековых письменных источниках. Имя Узбек впервые встречается в источниках XII в., это имя носили некоторые из тюркских правителей Ближнего и Среднего Востока. Происхождение топонима Узбекистан связано с именем правителя Золотой Орды Узбекхана. В XIV в. под названием Узбекистан понимали Золотую Орду. В ХV в. после распада Золотой Орды на несколько ханств название Узбекистан прилагалось к Узбекскому Улусу, т.е. государству кочевых узбеков, образованному в восточной части Золотой Орды. С нач. XVI в. топоним Узбекистан стал прилагаться ко всей Средней Азии, на территории которого было образовано государство Шайбанидов. Это название употреблялось в качестве синонима топонимов Туран и Туркестан вплоть до 1865 г., когда Средняя Азия была завоевана Российской империей. Исходя из этих данных, мы имеем все основания считать, что топоним Узбекистан, употреблявшийся 365 лет (с нач. XVI в. до 1965 г.) по отношению ко всей Средней Азии, был одним из исторических названий региона.

«Ўзбекистон»

атамаси

Олтин Ўрда

хукмдори Ўзбекхон

билан боғлиқ

бўлиб, XIV асрда

бу атама Олтин

Ўрда давлатига

нисбатан

қўлланилган

XV асрда Олтин

Ўрда хонликларга

парчаланиб

кетгандан кейин

«Ўзбек вилояти» ёки

«Ўзбекистон»

атамаси Дашти

Қипчоқнинг шарқий

қисмидаги Ўзбек

Улусига нисбатан

қўлланилган.

XVI асрда ўзбеклар

Мовароуннахрни

эгаллагандан кейин

то руслар

босқинига қадар

Ўзбекистон

атамаси бутун

Ўрта Осиё

минтақасига

нисбатан

қўлланилган 


\section{АКАДЕМИК ЯХЬЯ ГУЛЯМОВ - УЧЁНЫЙ И \\ ОРГАНИЗАТОР \\ НАУКИ}

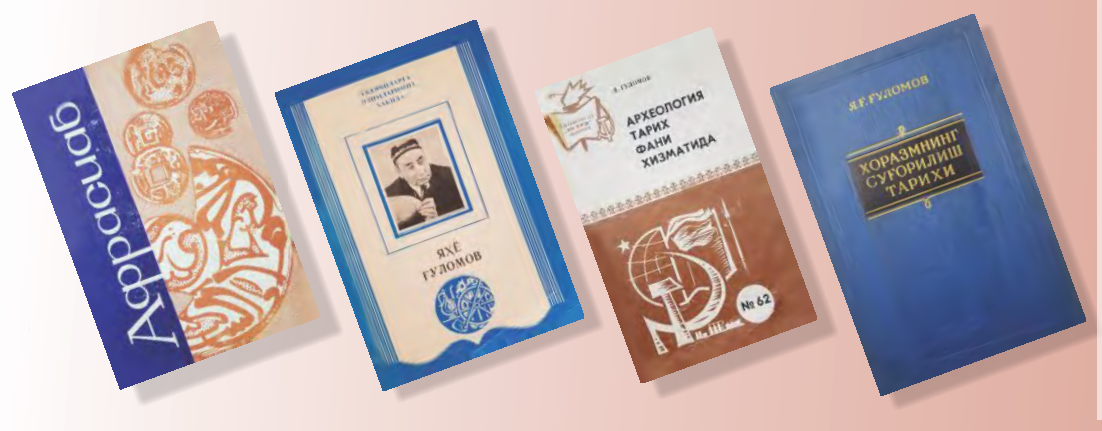

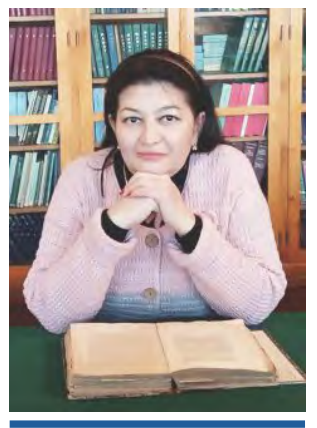

Феруза

Шамукарамова,

старший научный сотрудник Института истории Академии наук Республика Узбекистана

This essay is devoted to the vast scientific and practical activities of the famous historian - the academician Yahya Gulyamov, who was archaeologist, great specialist in history, head of numerous archaeological expeditions. The article presents the way of his rising from a young researcher to the immense specialist in historical science of Uzbekistan. The essay is of historical and historiographical character. In research there were used the documents of Ya. G. Gulymov's personal fund stored in the Central State Archive of the Republic of Uzbekistan, as well as the materials of documentary film «Umr Daftari", and his studies. A special attention is paid to his participation in protection of archaeological and historical monuments threatened to be destroyed.

Ключевые слова: Самарканд, Хорезм, археология, хорезмская экспедиция, памятники культура историческая наука, востоковедение, Зарафранская долина, П. Салиев, В.Л. Вяткин.

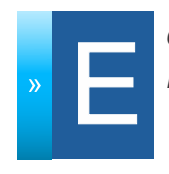

сли мы не сохраним историю, будущее поколение намэтого непростит.

Яхъя Гулямов

Первый археолог-узбек, известный специалист по древней истории Средней Азии, организатор науки, педагог Яхъя Гулямович Гулямов родился 1 мая 1908 г. в махалле Акмечеть города Ташкента. Его отец Гулям Maxсум был учителем медресе Ходжа Ахрара, мать Сорахон-отин - учительницей. У Гулям Махсума было шестеро детей - Эшонхон, Одилкори, Яхъя, Саид Ахмад, Акромхон и Рокия. Чтобы помочь мужу прокормить большую семью, Сорахон-отин держала у себя дома мактаб для девочек. В махалле она считалась самой образованной женщиной и пользовалась большим уважением ${ }^{1}$.

1918 г. после смерти отца десяти летний Яхъя остался на иждивении матери, а с 1921г. воспитывался в детском домеинтернате, где получили образование многие представители местной интеллигенции. Примечательно, что однажды при встрече со студентами в ответ на вопрос - «Кто был Вашим первым учителем?», Я. Гулямов ответил: «Моим первым учителем была моя мать, ее образ всегда передо мной, и всегда в моей памяти ${ }^{2}$. Благодаря матери уже в 7-8-летнем возрасте Яхъя Гулямов свободно читал книги на арабском и персидском языках

По окончании шестого класса школы в 1923 г. он продолжил учебу в Узбекском мужском институте просвещения в Ташкенте (Узинпрос), который окончил в 1926 г. К 1930 г. Я. Гулямов окончил также общественно-экономическое отделение Узбекского государственного педагогического института в Самарканде ${ }^{3}$.

В период учебы в Самарканде Я. Гулямов посещал лекции таких известных ученых, как П. Салиев, М. Саиджанов, В. Вяткин и др., которые оставили в его памяти неизгладимые впечатления. В последующем, вспоминая эти времена, Я. Гулямов характеризовал Пулата Салиева как знатока арабского, фрарси и турецкого языков, глубоко изучившего письменные источники по истории Средней Азии. Именно лекции П. Салиева во многом определили его интерес к истории региона. Пулат Салиев будучи первым узбекским историком, являлся ярчайшей фригурой в начуной об-

\footnotetext{
${ }^{1}$ Мухаммаджонов А. Яхё Ғуломовни хотирлаб. Тошкент: Шарқ, 2000. Б. 4-5.

${ }^{2}$ Академик Ахё Ғуломов. Тошкент, 1998. Б. 4.

${ }^{3}$ Биобиблиографические очерки о деятелях общественных наук Узбекистана / Составитель Б.В. Лунин. - Ташкент: Фан, 1976. С. 180.
} 
щественности того периода. Как один из наставников Я. Гулямова - П. Салиев ввел молодого студента в историческую науку, оказывал всемерную поддержку, в том числе и финансовую в годы учебы в Самарканде.

Однако наибольшее влияние на исследовательские интересы Яхъи Гулямова, в археологическом и востоковедческом направлениях, оказало знакомство с Василием Лаврентьевичем Вяткиным, известным знатоком Самаркандских памятников и археологом, обратившим внимание на любознательного студента, задававшего множество вопросов после каждой лекции.

Первая встреча Я. Гулямова с В.Л. Вяткиным произошла еще в 1921 г. во время экскурсии в Самарканд учеников 8-интерната Ташкента. Позже он вспоминал об этом: «В августе 1921 года некоторую часть воспитанников повезли на экскурсию в Самарканд, среди которых был я, будущий кинорежиссер Наби Ганиев, несколько учителей. Тогда нас разместили в ташкари (мужская часть дома) Усманбая в махалле Кошховуз. Тогда к Юсуфу Алиеву (преподаватель. - Ф.Ш.) часто приходил русский человек - высокий, с широким альлбом, с лысиной на голове, в очках, примерно лет пятидесяти. Одет он был в солдатские ботинки с толстой подошвой, сильно изношенные и выцветшие светлые брюки и рубашку каламинку с четырьмя карманами, а на голове плотная фуражка. Руки у этого человека были с выступающими венами как у кузнецов, пальцы огрубевшие и очень крупные» ${ }^{4}$.

Однако эта первая встреча оставила далеко не приятное впечатление у тринадцатилетнего Яхъи. В немалой степени этому также способствовало то обстоятельство, что при представлении В.Л. Вяткина ученикам интерната была названа его прежняя деятельность в качестве заместителя военного губернатора области и миссионера.
Позднее, уже в период студенчества в Самарканде, узнав, что лекции по курсу «История мусульманского Востока» будет читать В.Л. Вяткин, Я. Гулямов вместе с другими студентами обратились к директору института просрессору Меркуловичу с выражением недовольства. Однако их позиция в корне изменилась сразу же после первой лекции В.Л. Вяткина ${ }^{5}$.

Таким образом, очевидно, именно В.Л. Вяткин был тем человек, который постепенно пробудил интерес Я. Гулямова к археологии, день за днем, поэтапно, раскрывая юному студенту премудрости археологической науки. Одновременно В.Л. Вяткин регулярно снабжал своего протеже уникальными историческими произведениями Мухаммада Джарира Табари, Мухаммада Наршахи, Жувайни и других средневековых летописцев, приобщая его, таким образом, к богатейшему письменному историческому наследию.

Педагогическая деятельность Яхъи Гулямова началась в 1929 г. там же в Самарканде в качестве ассистента открывшегося при Самаркандском педагогическом институте кабинета истории Средней Азии. На эту должность Я. Гулямова рекомендовали П. Салиев, В.Л. Вяткин и А. Фитрат. В 1931 г. он был принят на работу преподавателем Педагогического техникума в Ташкенте. Одновременно с этим он проходил обучение в аспирантуре Узбекского научно-исследовательского института при Совнаркоме УзССР.

Первые научные публикации Я. Гулямова, посвященные изучению и сохранению памятников материальной культуры Узбекистана $^{6}$, истории ремесла ${ }^{7}$, проблеме спасения северо-восточного минарета медресе Мирзо Улугбека в Самарканде ${ }^{8}$ и другие ${ }^{9}$, стали появляться в начале 1930-х годов.

C 1933 по 1940 г. Я. Гулямов работал в должности научного сотрудника и ученого секретаря Узбекистанского комитета по ох-

${ }^{4}$ Ғуломов Я.Ғ. В.Л. Вяткин хақида хотиралар // ОНУ. 1969. № 11. С. 45. (Перевод воспоминаний с узбекс-кого осуществлен автором данной работы).

${ }^{5}$ Там же. С. 46.

${ }^{6}$ Гулямов Я.Ғ. Ўзбекистондаги моддий маданият обидаларини сақлаш ва ўрганиш йўлида // Моддий ма-даният обидаларини сақлаш ва ўрганиш Ўзбекистон қўмитаси. Материаллар. 9-тўплам. Тошкент, 1934; Его же. Ўзбекистонда қадимий обидаларни ўрганиш // Социалистик фран ва турмуш. Тошкент, 1939. № 1. Б. 20-22; Его же. Тарихий обидалар (Самарқанд ва Бухоронинг тарихий-меъморчилик обидалари) // Социалистик фран ва турмуш. Тошкент, 1939. № 12. Б. 23-25.

${ }^{7}$ Ғуломов Я.Ғ. Ёғоч ўймакорлиги санъати тарихидан// Машъал. Тошкент, 1935. № 3. Б. 20-22.

${ }^{8}$ Ғуломов Я.Ғ. Мирзо Улуғбек мадрасасининг шимолий-шарқий (қулаётган) минорасини тўғирлаш // Социалистик фран ва турмуш. Тошкент, 1938. № 11-12. Б. 22-24; Его же. Миноранинг таъмирланиши. (Самарқанд) // Социалистик фран ва турмуш. Тошкент, 1939. № 11. Б. 32-33.

${ }^{9}$ Ғуломов Я.Ғ. Қадимият изларидан (Кўба-Товдаги қадимий Хоразм зардуштийлар қабристони қазилмалари) // Гулистон. Т., 1937. № 4. Б. 6-8; Его же. Қадимий Пойканд // Гулистон. Тошкент, 1939. № 11. Б. $32-33$.
Яхъи Гулямова,

в археологическом

и востоковедческом

направлениях,

оказало знакомство

с Василием

Лаврентьевичем

Вяткиным,

известным

знатоком

Самаркандских

памятников и

археологом,

обратившим

внимание на

любознательного

студента,

задававшего

множество

вопросов после

каждой лекции

В.Л. Вяткин был

тем человек,

который

постепенно

пробудил интерес

Я. Гулямова

к археологии,

день за днем,

поэтапно,

раскрывая юному

студенту

премудрости

археологической

науки 


\section{Достаточно разносторонней}

была сорера научных интересов Яхъи

Гулямовича, однако, доминирующими направлениями

оставались

проблемы истории

орошения

Узбекистана

с древнейших

времен до середины

XX века, а также

истории древнего

общества

Средней Азии

Важной

составляющей указанной работы, наряду с археологи-

ческими

материалами, стали

сведения

письменных

ИсточнИКОВ, CO-

поставляя которые

Я. Гулямов

попытался от-

ветить на ряд

вопросов, основной

среди них: «Почему

страна, распола-

гавшая в древности

огромной

земельной

площадью,

громадными,

удобными для

орошения водными

ресурсами Аму-

Дарьи

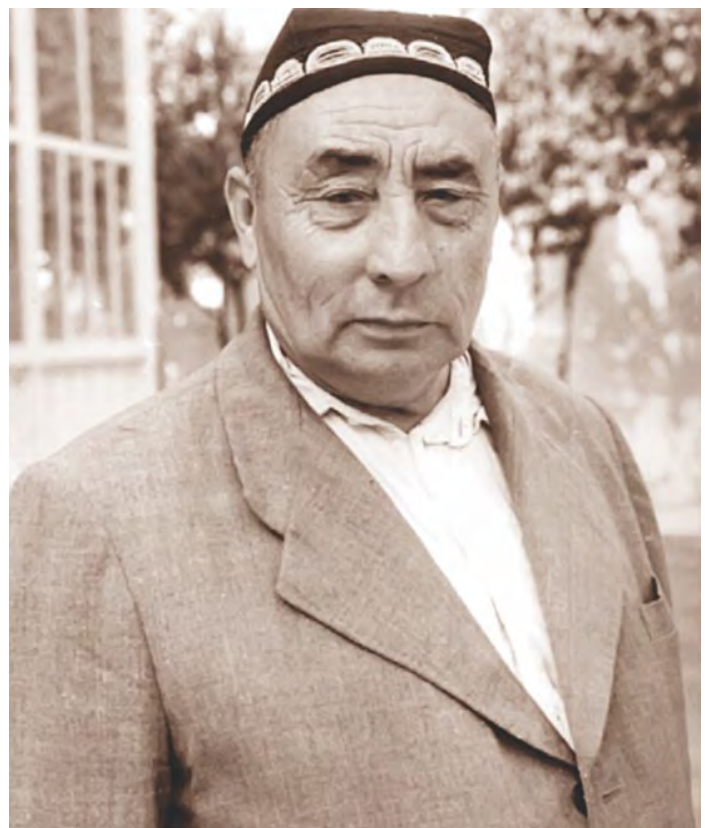

ране памятников старины и искусства (Узкомстарис). Здесь собственно и началось его систематическое участие в различных археологических экспедициях и разведках, в частности, в экспедиции М.Е. Массона на городище Айртам ${ }^{10}$, где он прошел большую практическую школу. В 1936 г. в отрогах Султан-Уиздага (Хорезм) Я. Г. Гулямов провел первые самостоятельные археологические изыскания. C 1938 г. ученый принимал участие в работе Хорезмской археолого-этнографической экспедиции (ХАЭЭ) Института истории материальной культуры АН СССР под руководством С.П. Толстова. Очевидно, в эти годы и сорормировался его интерес к истории и культуре древнего Хорезмского оазиса.

С 1940 г. Я. Гулямов - сотрудник Узбекистанского фрилиала Академии наук СССР сначала в качестве заведующего отделом археологии, а с 1943 г., с созданием Академии наук Узбекистана - заведывал отделом истории древних и средних веков при вновь созданном Институте истории и археологии АН УзССР. С ноября 1956 г. по октябрь 1959 г. Я. Гулямов исполнял обязанности директора данного института.

Параллельно с научной Я. Гулямов осуществлял и преподавательскую деятельность в Ташкентском государственном педагогическом институте им. Низами (ныне ТГПУ им. Низами), где читал лекции по истории Узбекистана и археологии.
Достаточно разносторонней была сорера научных интересов Яхъи Гулямовича, однако, доминирующими направлениями оставались проблемы истории орошения Узбекистана с древнейших времен до середины XX века, a также истории древнего общества Средней Азии.

В 1943 г. Я. Гулямов под научным руководством С.П. Толстова защитил диссертацию на соискание ученой степени кандидата исторических наук по теме: «Хива и ее памятники».

В 1950 г. он уже защитил докторскую диссертацию на тему: «История орошения Хорезма с древнейших времен до настоящих дней». Впоследствии эта работа была издана отдельной монографией (в 1957 г. - на русском $^{11}$, в 1959 г. - на узбекском языках), которая не утратила своей научной значимости и по сей день. По сути, данное исследование явилось первой попыткой последовательного освещения на основе археологического материала истории возникновения и развития системы орошения в низовьях Амударьи с древнейших времен до 50-х годов XX в.

Важной составляющей указанной работы, наряду с археологическими материалами, стали сведения письменных источников, сопоставляя которые Я. Гулямов попытался ответить на ряд вопросов, основной среди них: «Почему страна, располагавшая в древности огромной земельной площадью, громадными, удобными для орошения водными ресурсами Аму-Дарьи, не смогла выйти из состояния земельной тесноты ...»" ${ }^{12}$.

В процессе работы с письменными источниками, в частности, с произведением хивинского хана Абулгази «Шаджара-и турк» («Родословное древо тюрков»), Я. Гулямов внес существенные коррективы в вопросе полноценного авторства. Известно, что Абулгазихан в связи с болезнью завещал завершить свой труд своему сыну и преемнику Анушахану. Сопоставив различные списки рукописи, ученый пришел к заключению, что сочинение «Шаджара-и турк» было завершено не Ануша-ханом, как считалось прежде, а по поручению последнего «неким Махмуди бин Мухаммед Заманом Ургенджи». Более того, не только продолжено, но и «в значительной степени дополнено с введением новых глав».

\footnotetext{
${ }^{10}$ Ғуломов Я.Ғ. Қизилқумда (Хоразмнинг қадимий суғорилиш тарихидан) (1939 й. қазилмалар буйича) // Гулистон. Тошкент, 1939. № 6. Б. 31-33; Его же. Қизилқумдаги қадимий маданият излари // Социалистик фан ва турмуш. Тошкент, 1939. № 7-8. Б. 39-41; Хоразмнинг суғорилиш тарихидан // Гулистон. 1940. № 8-9. Б. 16-18.

${ }^{11}$ Гулямов Я.Г. История орошения Хорезма с древнейших времен до наших дней. Т.: Изд-во АНУзССР, 1957.

${ }^{12}$ Там же. С. 7.
} 
Несмотря на это, Я. Гулямов констатировал, что «самая ценная и самая основная часть этого труда принадлежит именно перу самого Абулгази» ${ }^{13}$. Тем самым исследователь внес значимые коррективы относительно истории создания этого ценнейшего исторического произведения, посвященного истории Хорезма.

Работая в составе Хорезмской археологоэтнографрической экспедиции под руководством С.П. Толстова, начатой в 1936 г., он осуществлял археологическую разведку Южного Хорезма. В течение восьми лет он осуществлял археологический надзор на строительстве Ташсакинского и Суанли-Ленин-ябского магистральных каналов, наблюдая за процессом чистки отдельных каналов и строительства железнодорожной линии Чарджо-уКунград, где ученому удалось собрать, постоянно беседуя с местным населением и строителями, сведения по многим аспектам ирригации региона ${ }^{14}$. В результате систематизации сведений письменных источников, народных преданий, материалов археологических работ, Я. Гулямову удалось собрать и обобщить значительный материал, результатом чего и явилась фундаментальная научная монография «История орошения Хорезма с древнейших времен до наших дней».

Важность данной работы была среди прочих особо отмечена руководителем Хорезмской археолого-этнографической комплексной экспедиции С.П. Толстовым: «Работа Я.Г. Гулямова является крупной разработкой одного из важнейших - по моему мнению, самого важного вопроса истории материальной культуры, точнее - истории хозяйства народов Хорезма и Средней Азии в целом. Я.Г. Гулямов не только обобщает весь этот огромный материал (имеется в виду новый материал, накопленный естественниками, инженерами-ирригаторами, археологами и историками. - Ф.Ш.), подвергая его критическому пересмотру - что одно было бы достаточным основанием для настоятельной необходимости публикации его книги. Он поднимает новый большой материал первоисточников. В течение долгих лет Я.Г. Гулямов работал заместителем начальника Хорезмской экспеди- ции, которая, как он правильно отмечает, внесла значительный вклад в историю древней ирригации Хорезма. Очень значительная часть этого вклада принадлежит непосредственно Я.Г. Гулямову. Им, кроме того, проведена огромная историко-этнографрическая собирательная работа - у местного населения, особенно у старых мирабов, собран интереснейший, исключительно важный материал по ирригации Хорезма XIX-начала XX века» ${ }^{15}$.

В марте 1955 г. Я. Гулямову было присвоено звание профессора. Уже через год, т.е. 5 октября 1956 г., он был избран членом-корреспондентом АН Узбекистана, а 25 фревраля 1966 г. - действительным членом национальной Академии наук. В июне 1958 г. Я. Гулямову присвоено звание заслуженного деятеля науки Узбекистана.

Известный среднеазиатский археолог, коллега Я. Гулямова - В.А. Шишкин особо подчеркивал, что «Я.Г. Гулямов из рядового научного сотрудника вырос в маститого ученого, хорошо известного своими научными трудами по археологии ${ }^{16}$.

Другой близкий соратник и коллега Я. Гулямова проф. Х.З. Зияев в своих воспоминаниях отмечал: «... Домла Яхъя Гулямов был для всех нас примером. Он был наставником не только для меня, но и для всех молодых исследователей. Он был очень скромным, смелым, щедрым и гостеприимным человеком и пользовался большим уважением. Я познакомился с Яхъя-ака в 1946 году и до конца его жизни вместе работал в одном институте. Но, прежде всего, Яхъя Гулямов был первым археологом-узбеком, ставшим кандидатом и доктором наук, и основоположником узбекской археологической науки» ${ }^{17}$.

Во второй половине 60-х годов XX в. в Узбекистане археологические изыскания обретают широкий размах. Этому способствовало создание в Институте истории и археологии АН Узбекистана, усилиями Я. Гулямова, двух отделов: 1) по изучению эпохи камня и бронзы, 2) по изучению истории орошения. Деятельность новых отделов дополнила и расширила круг научных направлений отдела археологии данного института. Исследования велись, в частности, по изучению древних и
Проведена

огромная историкоэтнографическая собирательная работа - у местного населения, особенно у старых мирабов, собран интереснейший, исключительно важный материал по ирригации

Хорезма XIX-начала XX века»

В марте 1955 г. Я. Гулямову было присвоено звание профрессора. Уже через год, т.е. 5 октября 1956 г., он был избран членом-

корреспондентом АН Узбекистана, а 25 февраля 1966 г. действительным членом национальной Академии наук

\footnotetext{
${ }^{13}$ Гулямов Я.Г. История орошения Хорезма с древнейших времен до наших дней... С. 12

${ }^{14}$ Гулямов Я.Г. История орошения Хорезма с древнейших времен до наших дней... С. 16

${ }^{15}$ ЦГАРУз, ф. 2883, оп. 1, д. 31, л. 1-3.

${ }^{16}$ Протокол № 1 заседания Ученого совета Института истории и археологии АН УзССР от 4 января 1966 г. Архив АНУзбекистана. С. 3-4.

${ }^{17}$ Из 4 серийного документального фрильма «Умр дафртари». 1-я серия.
} 
В последующие годы научной деятельности

Я.Г. Гулямов

руководил

археологическими

отрядами

исследующими

стоянки времен

палеолита, неолита,

энеолита $и$

бронзового века

в низовьях

Зарафршана и

в других районах

Узбекистана

С именем

Я.Г. Гулямова

связаны,

в частности,

первоначальные

раскопки ныне

широко известного

могильника

Заман-Баба

(заманбабинской

энеолитической

культуры степного

типа) в районе

западнее

Бухарского оазиса средневековых городов, поселений, культовых сооружений, могильников. Кроме того изучались стратиграфия, топографрия вышеназванных объектов ${ }^{18}$.

В эти годы под руководством Яхъя Гулямоввича продолжались интенсивные археологические работы на городище Афрасиаб в Самарканде, для сохранения целостности площади которого ученый приложил немало усилий. Масштабные стационарные исследования на городище проводились археологами Академии наук Узбекистана, Самаркандского и Ташкентского государственных университетов, Института искусствознания, в результате которых был осуществлен значительный научный прорыв в данном направлении ${ }^{19}$.

Наряду с академической деятельностью Я. Гулямов не забывал и об учебном процессе. Так, в 1969 г. в соавторстве с Р.Н. Набиевым был издан учебник по истории для 7-х и 8-х классов восьмилетних школ на узбекском языке ${ }^{20}$. А к 1971 г. данное учебное пособие выдержало четвертое исправленное издание и было переведено на русский язык ${ }^{21}$.

Возвращаясь к научным исследованиям Я. Гулямова по истории орошения Узбекистана, следует указать, что они имели большое народнохозяйственное значение, способствовали выявлению крупных земельных массивов древнего искусственного орошения, пригодных для этой цели и в наши дни: это западная часть Бухарского оазиса, низовья реки Кашкадарьи, район Нурата и др.

В последующие годы научной деятельности Я.Г. Гулямов руководил археологическими отрядами, исследующими стоянки времен палеолита, неолита, энеолита и бронзового века в низовьях Зарафшана и в других районах Узбекистана. В ходе этих работ установлен, например, исторический возраст города Бухары. Результатом исследований была публикация книги «Первобытная культура и возникновение орошаемого земледелия в низовьях Зарафшана» ${ }^{22}$, в которой ученый был одним из авторов и редактором. В рецензии на данную работу отмечалось, что выхода монографии «с таким нетерпением ждали не только археологи Средней Азии, но и специалисты по истории широкой зоны степей Евразии ... Выход книги ... является крупным научным событием ... открытие культуры на Махандарье - огромным достижением авторов ${ }^{23}$, так как в работе были затронуты важные научные проблемы.

С именем Я.Г. Гулямова связаны, в частности, первоначальные раскопки ныне широко известного могильника Заман-Баба (заманбабинской энеолитической культуры степного типа) в районе западнее Бухарского оазиса.

Ученик Я. Гулямова, академик АН Узбекистана А. Мухаммеджанов, вспоминая об этих годах, писал: «После Хорезмской археологической экспедиции домла организовал новый отряд из молодых, только встающих на научное поприще ребят, куда входил и я, и начал исследование южных районов Узбекистана. Цель работы состояла в выявлении перво бытных стоянок в низовьях Зарафршанской долины. Мы приехали на археологический объект, где произошел интересный момент. Домла поднялся на холм, и указывая рукой, стал показывать: «здесь был древний город, там были городские стены, вон там была цитадель, городские ворота находились с этой стороны, дальше был хауз (водоем. Ф.Ш.)». Я удивился и подумал про себя: «Домла все знающий гений что ли (домла луқмонмилар)?». Однако не решился задать вопрос - «Откуда Вы это знаете?».

Через два года в очередной сезон археологических раскопок мы поехали в Ромитанский район Бухарской области. Там мы наняли рабочих из местного населения, среди которых был мужчина постарше по имени Ешпулат. Этот мужчина стал объяснять молодым парням-рабочим, что Гулямов домла инженер, имеет большую подзорную трубу, наблюдая через которую из Ташкента выявляет места для поиска. Если он говорит «Копайте, здесь есть золото», значит так оно и

\footnotetext{
${ }^{18}$ Гулямов Я.Г. Некоторые итоги археологических работ в Узбекистане в 1967 - 1968 гг. // ИМКУ. Ташкент: Фан, 1972. Вып. 9. С. 3-10.

${ }^{19}$ Гулямов Я.Г. Об археологических исследованиях на городище Афрасиаб в 1967 - 1968 гг. // Афрасиаб. Ташкент, 1969. Вып. І. С. 268-293 (в соавторстве с Ю.Ф. Буряковым).

${ }^{20}$ История Узбекской ССР. Учебник для 7 и 8 классов восьмилетних школ. Ташкент: Укитувчи, 1969. - 108 с. (в соавторстве с Р.Н. Набиевым).

${ }^{21}$ История Узбекской ССР. Учебное пособие для 7-8 классов школ Узбекистана / Перевод с узбекского. Изд. 4-е, исправленное. Ташкент: Укитувчи, 1971. - 94 с. (в соавторстве с Р.Н. Набиевым).

${ }^{22}$ Первобытная культура и возникновение орошаемого земледелия в низовьях Зарафшшана. Ташкент: Фан, 1966 (в соавторстве с У Исламовым и А. Аскаровым).
} 


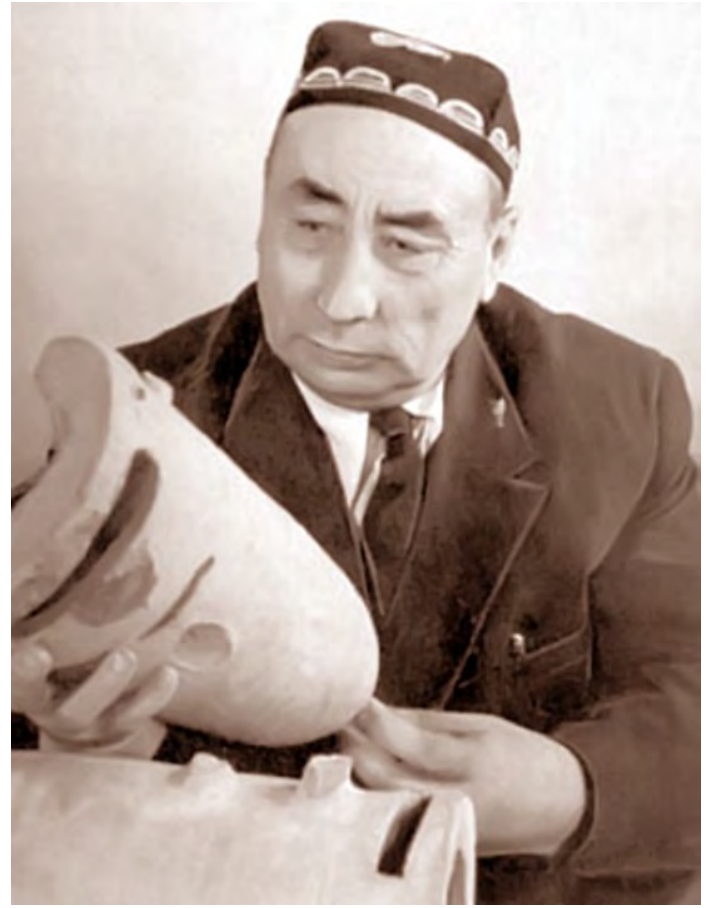

есть» ${ }^{24}$.

Яхъя Гулямович непосредственно участвовал и в археологическом исследовании древнего Ташкента. В частности, он возглавлял Ташкентский археологический отряд, созданный в 1967 г. на базе Института истории и археологии АН Узбекистана, в связи с ликвидацией последствий землетрясения 1966 г. Подавляющее большинство данного отряда составляли женщины-археологи, хотя Я. Гулямов не очень приветствовал их участие в археологических экспедициях, видимо, из-за тяжелых условий полевых работ, негативно влиявших на их здоровье. Цель первого этапа работ Ташкентского отряда заключалась в оказании так называемой «скорой помощи» обреченным на гибель и исчезновение памятников древней культуры Ташкента, на основе изучения которых следовало определить время сложения и развития древнейшего городского образования в районе долины Чирчика ${ }^{25}$. Следует отметить, что это был беспрецедентный случай в истории градостроительства, когда столица Узбекистана прев- ратилась в одну огромную строительную площадку, что в свою очередь способствовало проведению широких археологических исследований территории города как на застраивающихся площадках, так и в районах, наиболее интересных в археологическом плане.

Ташкентский отряд начал свою работу на всех строительных площадках города параллельно. Финансирование этих исследований закладывалось уже в сметы строительства новых микрорайонов. Каждый сотрудник отряда отвечал за закрепленный за ним сектор, на которые была разделена вся территория города $^{26}$. В процессе работ практически рождалась новая методика «городской археологии», когда зачистки стенок котлованов и траншей сочетались с извлечением из ковшей экскаваторов археологического материала или сбора его из уже вывезенного грун$\mathrm{Ta}^{27}$.

С работой Ташкентского отряда под руководством Я.Г. Гулямова связано открытие многослойной пещерной стоянки мустьерского времени, расположенной в Юго-Западных отрогах Тянь-Шаня в 70 км от Ташкента (грот Обирахмат), с работой Ферганского отряда обнаружение палеолитических и неолитических стоянок.

Начиная с конца XIX в., в различных академических периодических изданиях республики регулярно публиковались статьи и очерки, освещающие ход археологических работ на территории Узбекистана. Подобные публикации были подготовлены Н.С. Лыкошиным, М.Е. Массоном, В.А. Шишкиным. Эта традиция была продолжена и Я.Г. Гулямовым $^{28}$. В частности, в одной из таких статейотчетов об итогах археологических работ $\mathrm{AH}$ Узбекистана за 1966 г. сообщается, что год «ознаменовался созданием в Узбекистане Республиканского общества охраны памятников материальной культуры и истории». В том же году был проведен I учредительный съезд созданного Общества (30 марта 1966 г.), на котором при содействии Совета Ми-
Яхъя Гулямович непосредственно участвовал и в археологическом исследовании древнего Ташкента.

В частности, он возглавлял Ташкентский археологический отряд, созданный в 1967 г. на базе Института истории и археологии АН Узбекистана, в связи с ликвидацией последствий землетрясения 1966 г.

Ташкентский отряд начал свою работу на всех строительных площадках города параллельно. Финансирование этих исследований закладывалось уже в сметы строительства новых микрорайонов

${ }^{23}$ Советская археология. М., 1968. № 2. С. 302.

${ }^{24}$ Из четырехсерийного документального фрильма «Умр дасртари». 1-я серия.

${ }^{25}$ Древний Ташкент. Ташкент: Фан, 1973. С. 4.

${ }_{26}^{26}$ Филанович М.И. Ташкентский археологический отряд. Путевка в жизнь. (Рукопись статьи, любезно пре-доставленная автором).

${ }^{27}$ Филанович М.И. Вера Андреевна Булатова // Археологические исследования в Узбекистане. 2004 2005. Ташкент, 2006. Вып. V. С. 3-8.

${ }^{28}$ Гулямов Я.Г. Некоторые итоги археологических работ Академии наук УзССР в 1966 г. // ИМКУ. Ташкент: Фан, 1969. Вып. 8. С. 8-10; Его же. Некоторые итоги археологических работ в Узбекистане в 1967-1968 гг. // ИМКУ. Ташкент: Фан, 1972. Вып. 9. С. 3-10. 
Значительные усилия были приложены в 1970 г. в борьбе за сохранение гигантского городища Ахсикент в Наманганской области, когда «местные власти

у подножия городища построили кирпичный завод и начали с одного края долбить штольни для добычи земли

Необходимо отметить, что с именем

Я. Гулямова связаны мероприятия, направленные на определение возраста Самарканда (2500-летие) нистров Узбекистана было принято постановление: «1) об объявлении городища Афрасиаб археологическим заповедником и об улучшении его археологического изучения; 2) о проведении юбилея города Самарканда в связи с 2500-летием со дня основания» ${ }^{29}$.

Мы не случайно затронули проблему охраны археологических объектов на территории Узбекистана, так как этот аспект научной деятельности Яхъи Гулямовича занимает особую нишу. В годы своего директорства в Институте истории и археологии АН Узбекистана ученый приложил огромные усилия в борьбе за сохранение археологических объектов, вплоть до неоднократного обращения к руководству Узбекистана и лично Первому секретарю ЦК КП Узбекистана Ш.Р. Рашидову. Одно из таких обращений было связано с сохранением целостности древнего городища Афррасиаб в Самарканде. В 1966 г. Министерство дорог СССР начало строительство автодороги прямо через территорию городища. Узнав об этом, Я.Г. Гулямов добился приема у Ш.Р. Рашидова «и доложил о неслыханном кощунстве и издевательстве над выдающимся памятником», так как в результате строительства дороги городище Афрасиаб фактически разделялось на две половины. К тому же экскаваторы начали разрушать здание с уникальными настенными росписями, датированными VII - VIII веками. После доклада Я.Г. Гулямова Ш.Р. Рашидов лично посетил городище, и вызвав министра дорог республики, провел рабочее совещание непосредственно на городище. В ходе совещания руководитель республики отметив важное культурно-историческое значение городища, подчеркнул, что его уничтожение - неуважение к историческому наследию узбекского народа. Присутствовавший на встрече министр дорог попытался обосновать свои действия тем, что «строящаяся дорога просто делит памятник на две половины и особого урона он в этом не видит, не такой уж это грех» ${ }^{30}$.

В ответ на это заявление археолог И. Ахраров, ученик Я.Г. Гулямова, спросил чиновника: «Что бы вы сказали, если такую же дорогу проложить через центр древнего Новгорода?» (Министр дорог Узбекистана русской национальности - Ф.Ш.), на что министр без промедления ответил о невозможности подобного шага. «А почему же здесь на Афррасиабе можно это делать?» - с возмущением бросил И. Ахраров. Министр покраснел, но смолчал ${ }^{31}$.

Представленная ситуация - это лишь одно из многочисленных усилий Яхъя Гулямовича в деле сохранения археологических объектов. Значительные усилия были приложены в 1970 г. в борьбе за сохранение гигантского городища Ахсикент в Наманганской области, когда «местные власти у подножия городища построили кирпичный завод и начали с одного края долбить штольни для добычи земли, из которой фрормовали сырцовые кирпичи, обжигали их и продавали тем, кто в них нуждался» ${ }^{32}$.

В этом важном деле Яхъя Гулямовича можно назвать преемником В.Л. Вяткина и М.Е. Массона, которые также прилагали немало усилий, регулярно вступая в переговоры и переписку с властями для сохранения уникальных исторических объектов. Это позволяло также добиваться выделения дополнительного фринансирования для реставрации исторических архитектурных памятников Узбекистана.

Необходимо отметить, что с именем Я. Гулямова связаны мероприятия, направленные на определение возраста Самарканда (2500-летие). Начало было положено в 1958 г., когда в Самарканде на Афрасиабе начались стационарные раскопки, в дальнейшем превратившиеся (1965) в крупную археологическую экспедицию под руководством В.А. Шишкина. Накопившийся археологический материал вызвал бурную дискуссию в среде научной общественности, связанную с датировкой города. Одна группа ученых придерживалась позиции, сорормировавшейся еще в конце XIX в., что Самарканд (Мараканда) это столица Древнего Согда эпохи Александра Македонского. Другая группа занимала более сдержанную позицию, заключающуюся, в частности, в том, что «в античное время на этой территории находились лишь временные поселения, а городская жизнь здесь началась с сооружением первой и второй городских стен и стены цитадели в IV - VI вв. н.э.». Вспоминая эти годы, академик Ю.Ф.

\footnotetext{
${ }^{29}$ Гулямов Я.Г. Некоторые итоги археологических работ Академии наук УзССР в 1966 г.... С. 8.

${ }^{30}$ Ахраров И. Академик Яхъя Гулямович Гулямов - мой учитель и наставник // Академик Яхё Ғуломов замондошлари ва шогирдлари хотирасида. Тошкент: Фан, 2009. С. 30.

${ }^{31}$ Ахраров И. Академик Яхъя Гулямович Гулямов - мой учитель и наставник ... С. 30.

${ }^{32}$ Там же. С. 27-37.
} 
Буряков писал: «Возглавивший экспедицию после кончины В.А. Шишкина Яхъя Гулямович поставил в качестве одной из важнейших задач изучение возраста города. ...Эти исследования позволили утверждать, что материалы и орортиорикация дают возможность датировки возраста Самарканда не менее 2500 лет. Когда весной 1969 г. Я.Г. Гулямов выехал на сессию археологов и этнографов в г. Ленинград, его доклад на секции среднеазиатских специалистов вызвал такой резонанс, что возглавлявший конфреренцию руководитель ИИМК Б.Б. Пиотровский вынес этот доклад на заключительное пленарное заседание всесоюзной сессии. Доклад Я.Г. Гулямова был полностью поддержан всеми археологами страны, и материал экспедиции явился базовым для выдвижения первой датировки юбилея Самарканда» ${ }^{34}$.

Значителен вклад Я.Г. Гулямова и в подготовке кадров-археологов. Работа в составе ХАЭЭ утвердила его в важности проведения комплексных исследований всех этапов древней истории Узбекистана, для чего необходима была подготовка высококвалифицированных национальных кадров. Для осуществления этого плана ученый стал готовить молодых специалистов-археологов из числа выпускников Ташкентского педагогического института им. Низами. Работая в данном направлении, он осуществлял важные организационные мероприятия для отправки молодых специалистов на стажировку в ведущие научные центры Москвы, Ленинграда, Новосибирска и других регионов бывшего Союза. В частности, благодаря усилиям Я.Г. Гулямова подобную стажировку в свое время прошли ныне известные археологи - акад. А. Аскаров, акад. У. Исламов, Т. Мирсаатов, акад. А. Мухаммеджанов, д.и.н. Р. Сулейманов и др ${ }^{35}$. Под руководством Я.Г. Гулямова около тридцати исследователей из числа академических сотрудников и преподавателей вузов успешно защитили кандидатские и докторские диссертации по археологии и древней истории Узбекистана. Благодаря стараниям ученого в Узбекистане была подготовлена целая плеяда специалистов-археологов, чьи исследования нашли широкое признание в миро- вом академическом сообществе.

Комплекс мероприятий, осуществленный Я.Г. Гулямовым в деле подготовки высококвалифицированных кадров-археологов, способствовал образованию в Самарканде самостоятельного Института археологии в системе Академии наук Узбекистана, который ныне носит имя Яхъи Гулямова. Обосновывая важность образования отдельного Института археологии, ученый отмечал: «... Задача охвата больших территорий республики, отдельных городов и городищ как археологических объектов, да еще и подготовка научных кадров совершенно не под силу Институту истории и археологии АН УзССР, где археология представлена в двух секторах из девяти существующих. Практика организации и проведения археологических мероприятий показала невозможность дальнейшего сочетания этих двух самостоятельных видов научного исследования в рамках одного института....

В настоящее время археология в Инсти туте истории и археологии АН УзССР представлена: 1) сектором археологии эпохи камня и бронзы, 2) сектором археологии рабовладельческого и феедального периодов, 3) лабораторией археологической технологии, консервации и реставрации стенных росписей. Объем и разновидность археологических памятников чрезвычайно велики, а перспективы расширения археологических работ и подготовки кадров требуют придать работе новую организационную основу - учреждения самостоятельного Института археологии Академии наук Узбекской ССР» ${ }^{36}$.

В результате было принято решение об открытии в 1970 г. Института археологии АН Узбекистана в Самарканде. Переезд в Самарканд столичных специалистов-археологов вместе с членами их семей создал для последних определенные бытовые трудности, что не могло не отразиться на качестве исследований. Эта проблема, как показывают материалы личного архива Я.Г. Гулямова, также не осталась вне поля его внимания. В частности, нами обнаружена докладная записка, адресованная в 1973 г. в вышестоящие органы, в которой он характеризовал сло-
Значителен вклад

Я.Г. Гулямова и

в подготовке

кадров-археологов.

Работа в составе

ХАЭЭ утвердила

его в важности

проведения

комплексных

исследований всех

этапов древней

истории

Узбекистана,

для чего

необходима была

подготовка

высококвалифрици-

рованных

национальных

кадров

Под руководством

Я.Г. Гулямова

около тридцати

исследователей

из числа

академических

сотрудников и

преподавателей

вузов успешно

защитили

кандидатские и

докторские

диссертации по

археологии и

древней истории

Узбекистана

\footnotetext{
${ }^{33}$ Буряков Ю.Ф. Роль Я.Г. Гулямова в изучении цивилизации и городской культуры Средней Азии / Рукопись выступления Ю.Ф. Бурякова на научном семинаре, посвященной в 100-летию Я.Г. Гулямова, любезно предоставленная мне самим автором.

${ }^{34}$ Буряков Ю.Ф. Роль Я.Г. Гулямова в изучении цивилизации и городской культуры Средней Азии...

${ }^{35}$ Там же.

${ }^{36}$ ЦГАРУз, фр. 2883, оп. 1, д. 16, л. 10, 12.
} 


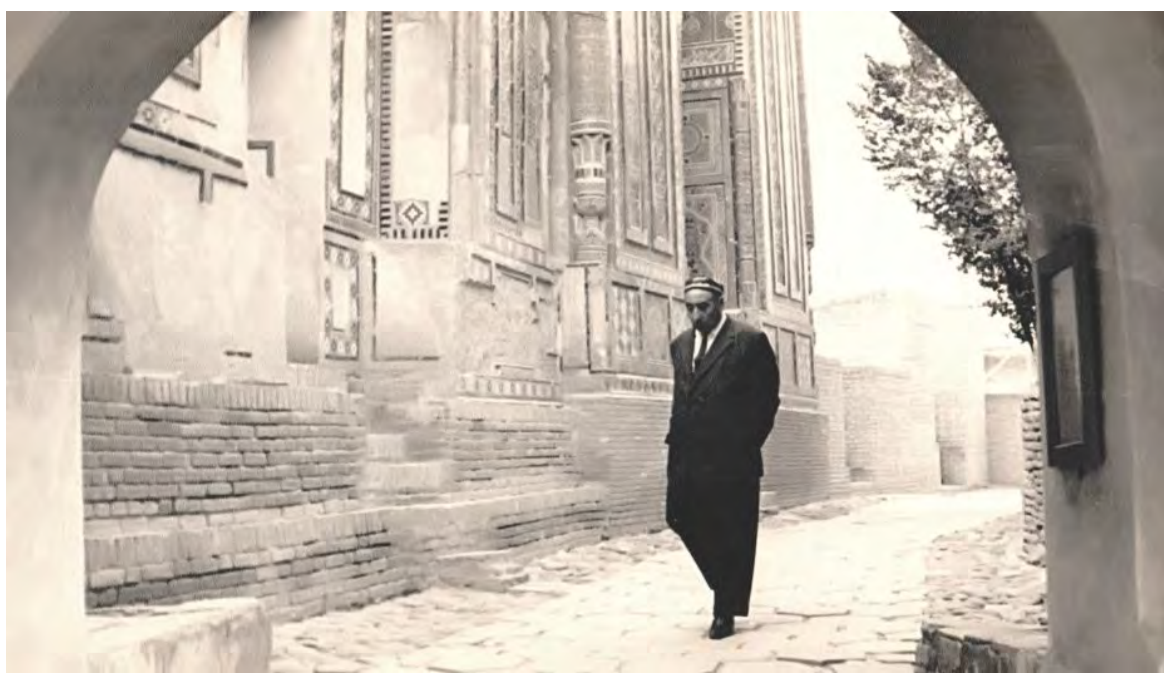

жившуюся ситуацию следующим образом:

«Вывоз Института в 1970 г. в гор. Самарканд, как показала его трехлетняя практика работы, нисколько не способствовал укреплению кадров и процветанию института, потому что: во-первых, еще ни один институт из системы Академии наук УзССР на практике

«Вывоз Института в 1970 г. в гор.

Самарканд, как

показала его

трехлетняя практика работы, нисколько не способствовал укреплению кадров и

процветанию

института, потому

что: вопервых

еще ни один институт из системы Академии

наук УзССР

на практике

не перебрасывался

в областной город не перебрасывался в областной город. Особенно нежелательно было это в момент организации, в результате чего новый и не имеющий еще опыта Институт сильно пострадал как в организационно-фринансовом, так и в моральном отношениях.

Во-вторых, для успешной работы археологов в Самарканде почти отсутствует научная база: ... (имеются в виду библиотеки, фонды музеев, центральные и ведомственные архивы, картографические учреждения - Ф.Ш.). ... сотрудники Института археологии больше половины своего рабочего времени тратят на разъезды между Самаркандом и Ташкентом....

В-третьих, в связи с переездом в гор. Сaмарканд, в момент своей организации Институт лишился почти половины квалифицированных археологов и опытных научно-вспомогательных кадров, которые в силу своих семейных и других серьезных обстоятельств остались в Ташкенте и работают не по специальности ...

Что же касается тех археологов, которые переехали в г. Самарканд, то трудно утверждать, что подавляющее большинство их охотно шло на это и едва ли сжилось с обстановкой. Тем более, что почти все они - уроженцы Ташкента, где имеют свои собственные дома, обжитые квартиры, личное хоз- яйство и окружающих родственников. От всего они оторвались ради службы в другом городе. ... Кроме того, постоянные разъезды между Самаркандом и Ташкентом стоит им больше половины их заработной платы.

В-четвертых, вся эта обстановка привела к тому, что у некоторых из сотрудников Института наступили серьезные семейные осложнения, ...»" ${ }^{37}$.

В качестве подтверждения в документе приведены имена более десяти известных археологов, которые оказались в сложной ситуации. Следующим шагом в борьбе за интересы ученых-археологов республики стало письмо Я.Г. Гулямова, адресованное 17 декабря 1973 г. Председателю Бюро Отделения языка, литературы и истории АН Узбекистана M.X. Нурмухамедову с инициативой организации в Ташкенте Отделения института археологии АН Узбекистана. Приводя доводы в пользу организации подобной структуры, ученый отмечал:

«Это полезное мероприятие помогло бы: во-первых, сосредоточить и рационально использовать археологические кадры в стенах Академии наук УзССР; во-вторых, эффрективно обеспечить организационные и научные связи Института археологии с академическими учреждениями, музеями, библиотеками, архивами, лабораториями, Республиканским обществом по охране памятников, Главным управлением по охране памятников и др.» ${ }^{38}$.

Следует также отметить вклад Яхъя Гулямовича в развитие музейного дела в Узбекистане. В одной из своих докладных записок исследователь выражает искреннюю озабоченность состоянием дел в данной сфрере: «В деле упорядочения охраны памятников большое место занимает систематизация и научная пропаганда памятников материальной культуры в музейных экспозициях. Каждая экспозиция музея, безусловно, должна основываться на новейшие результаты исторических, археологических и этнографических исследований, проводимых, в основном, в академических институтах. В этом деле соответствующие коллективы научных работников должны быть неразрывно связаны с отделами и секторами институтов.

Комплексы археологических находок с городищ, курганных могильников и иных видов памятников в обязательном порядке и в пол-

\footnotetext{
${ }^{37}$ ЦГА РУз, фр. 2883, оп. 1, д. 24, л. 1-4.

${ }^{38}$ ЦГА РУ 3, фр. 2883, оп. 1, д. 69.
} 
ном комплексе должны поступать в фронды одного музея и вноситься в единую фондовую книгу. Передачу дублетов и целых комплексов в другие музеи нужно производить из того же музея. Таким главным музеем в республике является Республиканский музей истории, ранее находившийся в системе $\mathrm{AH}$ Уз CСР. Его необходимо вернуть в систему АН УзССР и сделать главным академическим музеем, тесно связанным с Институтом истории и археологии $\mathrm{AH}$ УССР» $^{39}$.

Один из учеников Яхъя Гулямовича, академик У. Исламов, в своих воспоминаниях коснулся и этого вопроса: «Яхъя Гулямов внес большой вклад в организацию, образование и обогащение экспонатов Музея истории Узбекистана и многие годы был его научным консультантом. Нас он приводил в музей для тщательного изучения его экспонатов - археологических находок, хранящихся там, после чего вывозил на археологические раскопки. Потому что изучение экспозиций музея, их анализ является своеобразным искусством и требует немалых усилий и знаний. ... Он всегда повторял, что в изучении истории роль музея имеет большое значение ${ }^{40}$.

Другой ученик Яхъя Гулямовича - И. Ахраров, работавший со своим наставником с 1954 г. вплоть до последних дней жизни последнего (1977 г.), особо отмечал сложность политической и идеологической обстановки, в которой Я.Г. Гулямову удавалось реализовывать свои организационные и исследовательские начинания: «... Было трудно академику Я.Г. Гулямову, директору крупного института работать честно и бороться за развитие науки, испытывая давление даже со стороны верховной власти. Я в этой борьбе был всегда рядом с ним и мне были понятны все его тревоги» ${ }^{41}$.

Немаловажное значение в научной дея- тельности Я. Гулямова занимала его редакторская деятельность. Под его непосредственным редакторством был издан ряд крупных научных исследований, в частности, такие фрундаментальные работы, как перевод знаменитого произведения Захириддина Мухаммада Бабура «Бабур-намэ» общающая коллективная работа «История Узбекской ССР ${ }^{43}$, исследования С.А. Азимджановой ${ }^{44}$, Х.З. Зияева ${ }^{45}$, В.А. Шишкина ${ }^{46}$, Т. Кадыровой ${ }^{47}$, А.P. Мухамеджанова и Т. Нигматова ${ }^{48}$ и множество других.

Я. Гулямов был одним из авторов и членом главной редакционной коллегии нового, дополненного четырехтомного издания «История Узбекской ССР» $(1967-1968)^{49}$.

В 1966-1969 гг. Я.Г. Гулямов являлся Председателем Объединенного Ученого совета Отделения истории, языкознания и литературоведения АН Узбекистана по приему и защите докторских диссертаций, в 19691975 гг. - Председателем Объединенного Ученого совета по истории Отделения истории, языкознания и литературоведения $\mathrm{AH}$ Узбекистана и с 1976 г. до конца жизни Председателем специализированного Ученого совета по защите докторских диссертаций при Институте истории АНУзбекистана.

Я.Г. Гулямов был награжден рядом правительственных наград: в 1948 г. медалью «За доблестный труд в Великой Отечественной войне 1941-1945 гг.», в 1970 г. медалью «За доблестный труд», двумя Почетными грамотами Президиума Верховного Совета УзССР, Почетной грамотой Президиума Верховного Совета ККАССР и др. В 2002 г. Указом Президента Республики Узбекистан ученый посмертно награжден медалью «Буюк хизматари учун ${ }^{50}$.

Примечательно то, что Яхъя Гулямович не

${ }^{39}$ ЦГА РУз, фр. 2883, оп. 1, д. 69.

${ }^{40}$ Из четырехсерийного документального орильма «Умр дафртари». 3 серия.

${ }^{41}$ Ахраров И. Академик Яхъя Гулямович Гулямов - мой учитель и наставник... С. 27-37.

${ }^{42}$ Бабур Захириддин Мухаммад. Бабур-намэ / Перевод Салье. Отв. ред. Я.Г. Гулямов. Ташкент, 1947.

${ }^{43}$ История Узбекской ССР. Книга первая / Под ред. Я.Г. Гулямова и др. Т.: Изд-во АН УзССР, 1955. Т. І.

${ }^{44}$ Азимджанова С.А. К истории Ферганы второй половины XV в. / Отв. ред. Я.Г. Гулямов. Ташкент: Изд-во АН УзССР, 1957. - 94 c.

${ }^{45}$ Зияев Х.З. Ўрта Осиё ва Сибирь (XVI - XIX асрлар) / Масъул мухаррир Я.Ғ. Ғуломов. Тошкент:

Ўзранакад-нашр, 1962; Его же. Средняя Азия и Сибирь / Отв. ред. Я.Г. Гулямов. Ташкент: Фан, $1962 ;$ Его же.

Средняя Азия и Поволжье / Отв. ред. Я.Г. Гулямов. Ташкент: Фан, 1965.

${ }^{46}$ Шишкин В.А. Варахша / Отв. ред. Я.Г. Гулямов. М.: Изд-во АН СССР, 1963. - 250 с.

${ }^{47}$ Кадырова Т. Из истории крестьянских движений в Мавераннахре и Хорасане в VIII - начале IXв. / Отв. ред. я.Г. Гулямов. Ташкент, 1965. -240с.

${ }^{48}$ Мухамеджанов А.Р., Нигматов Т. Некоторые источники к истории взаимоотношений Бухары и Хивы с Россией / Отв. ред. Я.Г. Гулямов. Ташкент, 1957.

${ }^{49}$ История Узбекской ССР. В 4-х томах/ Редколлегия: Я.Г. Гулямов и др. Ташкент: Фан, 1967-1968. T. I-IV.

${ }^{50}$ Награда была вручена его дочери Сакине Гулямовой.
Немаловажное

значение в научной деятельности

Я. Гулямова

занимала

его редакторская

деятельность.

Под его

непосредственным

редакторством

был издан ряд

крупных научных

исследований

В $1966-1969$ гг.

Я.Г. Гулямов являлся

Председателем

Объединенного

Ученого совета

Отделения истории,

языкознания и литературоведения

АН Узбекистана

по приему и защите

докторских

диссертаций,

в 1969 - 1975 гг 
был членом партии. В процессе написания данной работы я пыталась найти причину не вступления его в ряды членов коммунистической партии, так как он жил в тот период, когда идеологический прессинг был настолько сильным и человек, будучи занимающий определенный официальный пост, был обязан быть членом партии. Однако ответ на этот вопрос я получила случайно и неожиданно, в присланном на мою электронную почту письме внуком П. Салиева. Оказывается, в одной из бесед воспоминаний с дочерью П. Салиева Я.Гулямов сказал: “Фаридахон ${ }^{51}$, мой домла не был членом партии и я вступать в неё не буду».

Известный отечественный медиевист Р.Г. Мукминова, в судьбе которой Я. Гулямову также было суждено сыграть важную роль, вспоминала: «Он был приветливым, доброжелательным не только на работе, но и дома был очень гостеприимным человеком. Мы к нему домой приходили как к своим родителям. Супруга Яхъи Гулямовича - Собирахон ая, когда бы мы не приходили, приветливо встречала, накрывала на стол, готовила вкусные блюда. Ворота их дома всегда были открыты.

Когда женился мой старший сын, Яхъяака и Собирахоная пришли на свадьбу и дали благословение молодым. Я вспоминаю многие моменты в моей жизни, когда Яхъяака давал мне правильные советы. Он всегда был для нас примером» ${ }^{52}$.

Д.А. Алимова, руководитель Республиканского научного семинара «История уз- бекского народа и его государственности» имени Я.Г. Гулямова ${ }^{53}$, отмечает: «Есть такие личности, сила, образ и дух которых оказывают очень большую поддержку и после их смерти. Яхъя Гулямович входит в число таких людей. В 1998 году Президент Узбекистана на встрече с группой историков поставил перед учеными две задачи: первая - когда начала формироваться государственность на территории Узбекистана; вторая - когда формировалась и как развивался этногенез узбекского народа. Ставя эти задачи перед учеными-историками, первым кого вспомнил Президент, был Яхъя Гулямович» ${ }^{54}$.

$$
\text { *** }
$$

За последние годы был издан ряд сборников, брошюр, посвященных памяти крупного ученого-историка, востоковеда, археолога, организатора науки, защитника исторических памятников Узбекистана Яхъи Гулямовича Гулямова ${ }^{55}$. Узтелерадиокомпания создала замечательные документальные фрильмы под названием «Биринчи қалдирғоч» («Первая ласточка») и «Умр дафртари» («Тетрадь жизни»), в которых отражены все грани научной деятельности ученого. И это не спроста. Переоценить вклад Я.Г. Гулямова в развитие и организацию исторической науки, особенно археологии, не представляется возможным. Его жизнь и научная деятельность еще долго будут служить примером не для одного поколения ученых.

\section{Феруза Шамукарамова - Ўзбекистон Фанлар академияси Тарих институти катта илмий ходими. \\ Мазкур очерк машхур тарихчи археолог, тарих фани ва кўп сонли археологик экспе- дициялар ташкилотчиси академик Яхё Ғуломович Ғуломовнинг серқирра илмий ва ама- лий фаолиятига бавишланади. Унинг ёш тадкикотчидан то Ўзбекистонда тарих фани- нинг буюк арбоби бўлиб шаклланишигача босиб ўтган йўли ёритилган. Очерк тарихий- тарихшунослик характерга эга бўлиб, уни Ўзбекистон Марказий давлат архивида сақла- наётган Я.Ғ. Ғуломовнинг шахсий фонди хужжатлари, «Умр дафтари» хужжатли фильм маълумотлари, шунингдек унинг илмий ишларидан фойдаланилган. Шунингдек, олимнинг Ўзбекистон худудидаги йуцолиб кетиш хавфи бўлган археологик ва тарихий ёдгорликларни сақлашдаги ролига эътибор берилган.ш}

\footnotetext{
${ }^{51}$ Фарида Пулатовна Мухитдинова (Салиева) - историк-востоковед, 30 лет проработала в НИИ Востоковедения АНУзбекистана

${ }^{52}$ Интервью из четырехсерийного документального орильма «Умр дафттари». 3-я серия.

${ }^{53}$ На протяжении 14 лет в Институте истории АНРУз плодотворно функционирует республиканский научный семинар «История узбекского народа и его государственности» имени Яхъи Гулямова, председателем которого является профессор Д.А. Алимова. Данный научный семинар на сегодняшний день провел 69 научных заседаний республиканского и международного масштаба в городе Ташкенте и почти во всех учебных заведениях республики, где со своими докладами выступали ведущие ученые республики по всем актуальным проблемам исторической науки Узбекистана.

${ }^{54}$ Интервью из четырехсерийного документального фрильма «Умр дастари». 4-я серия.

${ }^{55}$ Академик Яғё Ғуломов. Т., 1998. - 68 бет; Мухаммаджонов А. Яғё Ғуломовни хотирлаб. Тошкент: Шарқ, 2000. -61 бет; Академик Яхё Ғуломов замондошлари ва шогирдлари хотирасида. Тошкент: Фан, 2009. - 120 бет.
} 

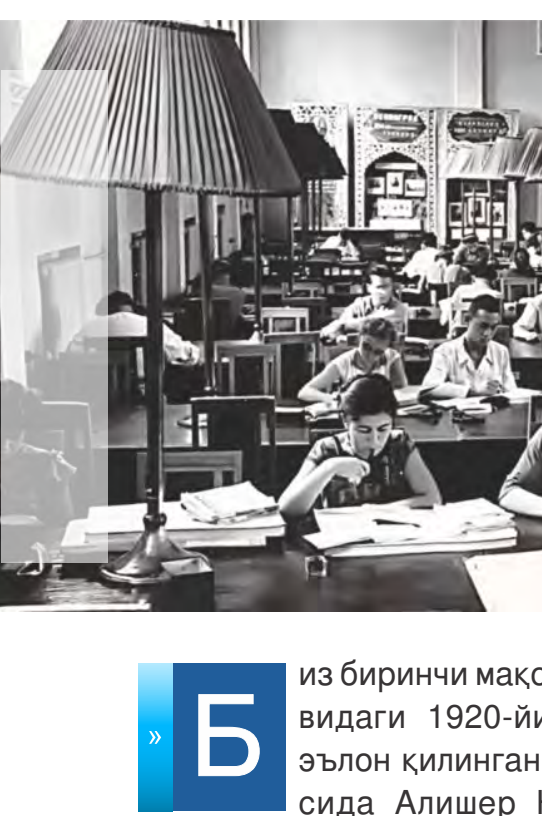

ख
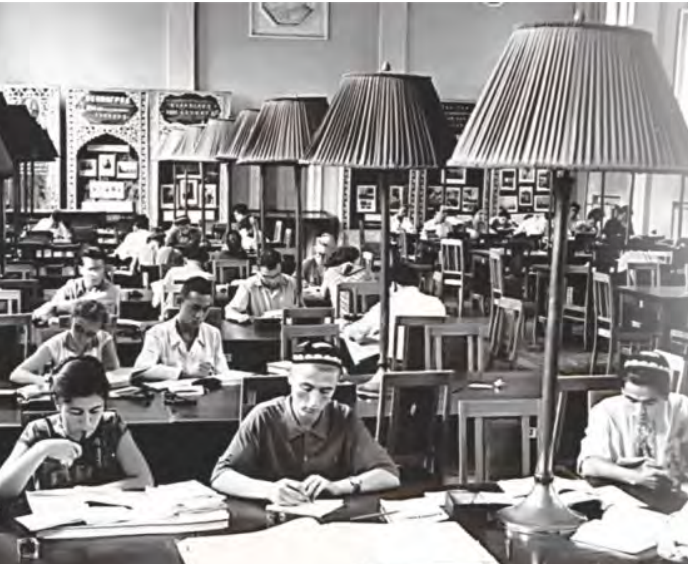
co .
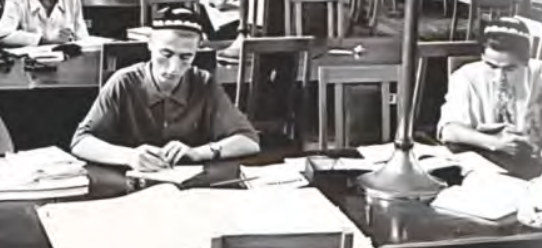

$+2-\frac{1}{2}$ I $\rightarrow 2>$

из биринчи мақоламизда араб ёзувидаги 1920-йиллар матбуотида эълон қилинган материаллар асосида Алишер Навоий номидаги Ўзбекистон Миллий кутубхонасининг тарихидан хикоя қилган эдик.

Ушбу мақолада эса, Ўзбекистон Миллий кутубхонасининг 30-40-йиллардаги тарихидан сўз юритамиз.

Юртимизда 1931 йилдан 1940 йилгача лотин ёзувида нашр этилган даврий матбуот нашрларини куцздан кечирсак, улар сахифаларида энг кўп тилга олинган кутубхона хозирги Ўзбекистон Миллий кутубхонаси эканлигининг гувохи бўламиз. Ушбу маскан хақидаги материаллар «Қизил Ўзбекистон» ва «Ёш ленинчи» газеталарида хамда «Гулистон» ва «Социалистик илм ва техника» жур-налларида эълон қилинган. Бу эътиборли манбаларда эълон қилинган материаллар бизга кутубхонанинг 30-йиллардаги фаолияти хақида қимматли маълумотларни тақдим этади.

Энг аввало, мазкур кутубхонага катта эътибор қаратиб, фраолиятини тўлиқ ёритган «Қизил Ўзбекистон» (хозирги «Ўзбекистон овози») газетасига мурожаат қиламиз. Унда 1931 йилдан 1940 йилгача кутубхона хақида 25 та мақола ва хабар чоп этилган. Бу материалларни ўрганиш асносида шу нарса маълум бўладики, кутубхона, асосан, 3 йўналишда фраолия турини олиб борган: илмий ходимлар томонидан чиқарилган библиографик кўрсаткич, илмий асар, альбом ва тўпламлар орқали, таниқли шахслар ёки бирон-бир машхур асарга бағишланган адабий кечалар ўтказиш йўли билан хамда мухим саналарга бағишланган куургазмалар ташкил қилиш орқали. Қуйида улар билан сизларни батафсил таништирамиз.

«Қизил Ўзбекистон»нинг 1934 йил 27 февраль сонида «Зўр маданий бир бино» номли мақола эълон қилинган. Унда ёзилишича, Ўр-

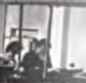
in

\section{ЎЗБЕКИСТОН МИЛЛИЙ КУТУБХОНАСИ ТАРИХИДАН}

Кутубхонанинг

1930-1940-йиллардаги фраолияти

(Мақоланинг биринчи қисми №4/2019 й. сонида чоп этилган)

та Осиё Давлат кутубхонасининг хозирги биноси талабга жавоб берадиган ахволда бўлмагани учун, кутубхона учун янги махсус бино барпо этиш кўзда тутилган. Мақолада кутубхона учун қурилажак бинонинг лойихаси хақида маълумот берилган.

Ўша йили Эрон ва бошқа мамлакатларда, шунингдек, бизнинг диёримизда хам машхур «Шохнома» асарининг муаллифии Фирдавсий таваллудининг 1000 йиллиги кенг нишонланган. 1934 йил 13 октябрь куни Тошкентдаги Фан комитетида Фирдавсийнинг 1000 йиллик юбилейига бағишланган кеча хам бўлган. Ўрта Осиё Давлат кутубхонаси хам бу мухим тадбирдан четда қолмаган. Бу хақдаги маълумотни биз газетанинг 1934 йил 18 май сонида босилган Б.С. Сергеевнинг «1000 йиллик юбилей: Фирдавсий асарларининг кўргазмаси» деган хабаридан билиб олишимиз мумкин.

Газетанинг 1934 йил июль сонларида «М.» имзоси билан ёзилган 2 та мақола эълон қилинган. Улардан биринчиси газетанинг 1934 йил 12 июль сонида босилган бўлиб, «4 минг қўлёзма: Ўрта Осиё тарихига тегишли асарлар» деб номланган. Унда Ўрта Осиё кутубхонасида сақланган Ўрта Осиё тарихига оид нодир қўлёзма асарлар хақида маълумот берилган.

2-мақола эса, газетанинг 1934 йил 24 июль сонида чоп этилган «Китоб ўқумоқчимисиз?: Бир йилдан кейин келинг...» сарлавхали мақоласидир. Унда айтилишича, Ўрта Осиё кутубхонасининг директорлари 1930-1934 йиллар ичида 9 марта алмашган, бунга сабаб уларнинг кутубхона ишларини тўғри йўлга қўя олмаганликлари бўлган. Шунинг учун 1933 йилда кутубхонадан фойдаланувчилар сони сезиларли даражада камайган, айниқса, махаллий миллат вакилларидан иборат бўлган ўқувчилар сони кескин қисқарган. Муаллиф кутубхонанинг мавжуд камчиликларидан сўз

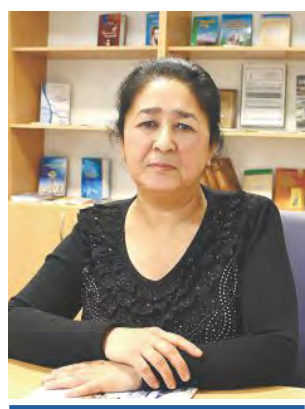

Феруза Нуриддинова, библиограф, манбашунос

«Китоб

ўқумоқчимисиз?:

Бир йилдан кейин келинг...»

сарлавхали

мақоласидир.

Унда айтилишича,

Ўрта Осиё

кутубхонасининг

1930-1934 йиллар

ичида 9 марта

алмашган, бунга сабаб уларнинг кутубхона ишларини тўғри йўлга қўя олмаганликлари бўлган директорлари 
Тошкент Давлат умумий

кутубхонасининг илмий ходими Ибодулла Одилов хақида сўз боради.

«Китобчи

билимдон» дея

таърисрланган Ибодулла Одилов, асосан, кутубхона

жамғармасида

сақланган қўлёзма

асарлар, хусусан шеърият мулкининг

султони Алишер

Навоий асарларини тадқиқ этиш билан

шуғулланган

Марям

Султонмуродова

Журналист

сифатида кўп

ишлай олмади.

30-йиллар

охирларида

қатағон бўрони

авж олиб, не-не

орзу умидлар

билан Германияда

ўқиб, етук

мутахассис бўлиб

қайтган ўзбек

йигит-қизлари

«халқ душмани»

тамғаси билан

махфр этилди.

Марям хам хеч бир

айби бўлмагани

холда узоқ йиллик

қамоқ жазосига

махкум этилди очиб, унинг иш усулларини бутунлай ўзгартириш кераклигини таъкидлаган:

«...Урта Осиё кутубхонаси дирексиясининг бемазагарчилиги шу даражага бориб етдики, кутубхонанинг адресига юборилган китоблар бир неча ойлаб Тошкент товар стансасида чанг босиб ётади, хатто бир вақт бундай китобларнинг бир қисми кутубхона томонидан олинмаганлиги сабабли, ким ошди савдоси билан сотилди.

Кейинги 4 йил ичида кутубхонанинг директори 9 маротаба алмаштирилди, бу директорлар кутубхона ишини йўлга қўя олмадилар. Китоблар бино бўлмаганлиги сабабли тартибсиз холда тўпланиб ётади, зах босиб чириш олдида туради. Китоблар каталоги нотуғри тузилган. Кутубхона Шарқ тилларида чиқатурғон вақтли матбуотдан ўзида қандай асарлар бор эканлигини билмайди. Миллий ёзувчиларнинг китоблари йўқ деярлик. Лохутий, Айний ва бошқа ёзувчиларнинг фрақат бир-иккитагина асарлари бор.

Кутубхонада IX, X, XVI, XVII ва кейинги асрлардан қолғон Шарқ тилларида ёзилмиш энг нодир қўлёзма асарлардан 4000 таси сақланади. Бу асарлар шу вақтгача текширилмай ва тартибга солинмай қолғон. Эндигина бу асарлар тартибга солина бошламоқда.

Мана шуларнинг хаммаси кутубхонага келиб, фройдаланувчиларнинг камайишига сабаб бўлаётир. 1932-нчи йилда 63 минг киши кутубхонадан фройдаланган эди. 1933-нчи йилгача фрақат 54 минг киши фойдаланди. Ерли миллатлардан бўлган ууқувчиларнинг сони, айниқса, камайди. Агарда булар 1932-нчи йилда 18 протсентни ташкил қилғон бўлса, 1933-нчи йилда 11 протсентга тушиб қолди.

Комиссия кутубхонани ўпурилишдан чиқариш учун тегишли тадбирларни белгилади. Кутубхона учун янги бино солишгина етмайди, балки унинг иш методларини бутунлай ўзгартиш зарур».

Шу ўринда бир нарсани алохида таъкидлаш керакки, «Қизил Ўзбекистон» сахифраларида ушбу кутубхонада хизмат қилган илмий ходимлар хақида хам материаллар бериб борилган. Бунга мисол қилиб газетанинг 1935 йил 24 июнь сонида босилган «Китобчи билимдон» деган кичик хажмдаги мақолани келтирамиз. Унда Тошкент Давлат умумий кутубхонасининг илмий ходими Ибодулла Одилов хақида сўз боради. «Китобчи билимдон» дея таърифрланган Ибодулла Одилов, асосан, кутубхона жамғармасида сақланган қўлёзма асарлар, хусусан шеърият мулкининг султони Алишер Навоий асарларини тадқиқ этиш би- лан шуғулланган. У 1939 йилда Алишер Навоийга унинг замондошлари томонидан ёзилган мактубларни тўплаб, 90 бетлик альбом тайёрлаган.

1935 йилда мазкур маърифрат масканининг 65 йиллик юбилейи кенг кўламда нишонланган. Шу муносабат билан газетада «Н. Ш.» имзоси билан 2 та мақола чоп этилган. Биринчи мақола газетанинг 1935 йил 28 сентябрь сонида босилган бўлиб, «65 йиллик юбилей: Бир миллион китоб» деб номланган. Ундан маълум бўлишича, Тошкент Давлат кутубхонаси бир миллион китобдан иборат бўлган катта хазинага эга бўлган.

Иккинчи мақола 1935 йил 4 октябрь сонида босилган бўлиб, «Юбилей кўргазмаси: Давлат кутубхонасининг 65 йиллик тўйи» номли мақоладир. Унда кутубхона ўзининг 65 йиллик тўйини муносиб нишонлаш учун катта тайёргарлик кўргани ва кутубхонанинг тарихини ёритувчи юбилей кўргазмасини ташкил қилгани айтилган.

Кутубхонанинг 65 йиллик юбилейи муносабати билан «Социалистик илм ва техника» ва «Гулистон» журналларида хам мақолалар эълон қилинган.

Биз эътиборимизни «Гулистон» журнали (1925 йилдан чиқа бошлаган бу журнал дастлаб «Ер юзи», 1932 йилдан «Ўзбекистон қурилишида», 1934 йилдан «Машъала», 1935 йилдан «Гулистон» номларида чиққан)га қаратамиз. Журналнинг 1935 йил 4-сонида «Марям» имзоли «Илм-фран хазинаси» сарлавхали катта мақола чоп этилган. Мақола муаллифри хақида икки оғиз сўз. Журналист Марям Султонмуродова 1905 йили Хивада туғилган. 1922 йилда илм истагида хорижга кетган ёшлар орасида Марям хам бор эди. Ўзбек қизларининг пешқадамларидан бўлган Марям Германияга бориб, у ерда Педагогика мактабида тахсил олган. Она юртга қайтгач, «Ёрқин турмуш» (хозирги «Саодат») журнали тахририятида адабий ходим, шунингдек «Гулистон» журналида хам фраолият кўрсатган. У мазкур журналларда «Марям», «М. Султонова» имзолари билан мақола ва очерклар эълон қилган. Бироқ у журналист сифратида кўп ишлай олмади. 30-йиллар охирларида қатағон бўрони авж олиб, не-не орзу умидлар билан Германияда ўқиб, етук мутахассис бўлиб қайтган ўзбек йигит-қизлари «халқ душмани» тамғаси билан махср этилди. Марям хам хеч бир айби бўлмагани холда узоқ йиллик қамоқ жазосига махкум этилди. Жабрдийда аёл-нинг ёшлик йиллари тутқунликда, зулматда ўтди. Бу матонатли аёлнинг ўша давр матбуо-тида 
эълон қилган мақолалари бугунги кунда хам ўз ахамиятини йўқотмаган. Унинг «Илм-фран хазинаси» номли мақоласида кутубхона тарихи, унинг бўлимлари, фондлари, ходимлари хамда кутубхонанинг келгусида режалаштирган ишлари хақида муфассал маълумот берилган. Унда ёзилишича, кутубхона жамғармасида 750 мингдан ошиқ китоб мавжуд бўлган. Кутубхонага 1934 йилда 5900 та китоб, 2757 та журнал ва 8000 дона газета олинган. Зиё масканида кутубхонанинг 65 йиллик юбилейини ўтказишга тайёргарлик бошланган. Мақола катта ахамиятга молик бўлгани учун қуйида уни тўлалигича келтирамиз:

«Эски ва янги илмий адабиёт бойликлари бир марказга тўплаб, ундан фройдаланиш йўлида хизмат кўрсатувчи илмий муассасалардан бири Ўзбекистон халқ Давлат кутубхонасидир.

Бу кутубхона 1870-нчи йилда очилган эди. Чор хукуматининг кутубхонани очишдан мақсади уни мустамлакачилик манфраатига ишлатиш, Ўрта Осиёни хар тарафрлама ўрганиш, уни тамомила қўлда сақлаб қолишни таъмин қилиш эди. Кутубхонанинг олдига оммани оқартиш, фикрий ва ғоявий саводини ортдириш деган вазифа қўйулғон эмас эди.

Инқилобдан сўнг бу илмий хазина пролетар хокимияти қўлиға кўчди ва мустамлакачилик, миссионерлик ғояларидан тозаланиб, маданий-оммавий тарбия манбаига айлантирилди.

Кутубхонага қатнаб юрганларнинг ўзлари унинг ички хаётини, унда қандай ишлар олиб борилганини билмайдилар. Кутубхонанинг ички хаёти эса жуда қизиқарлиқдир.

Ўзбек Давлат кутубхонаси бутун Иттифоқда чиқиб турғон хамма асарларни олиб туруши мажбурий бўлган 9 та кутубхонанинг биридир. Кутубхонага китоблар палатаси томонидан хар бир янги чиққан китобдан бир нусхаси пулсиз юборилиб туради. Бунинг устига яна ўқувчиларнинг заказларига қараб кутубхонада йўқ китобларни олдириб туруш Комплектлаш бўлумининг вазифрасидир.

Янги келган китобларни хисобга олиш ва каталог тузуш, классисрикатсия (турларга ажратиш) учун Ишлаб чиқариш бўлумига топширилади. Бу бўлумда китоблар ишланиб тамом бўлгач, Умумий китоб сақланатурғон, яъни ўқувчиларни китоб билан таъмин қилиб туратурган бўлумга келади.

Авваллари, Шарққа оид Оврупо ва Шарқ тилларида бўлган китоблар Шарқ бўлумига ажратилар эди. Бу бўлумнинг вазифаси ўқув- чиларни Шарққа оид китоблар билан таъмин қилиб туруш бўлса-да, бу вазифани тўла бажара олмаганидан Ўлкани ўрганиш бўлумига айлантирилди. Хозир бу бўлум ўз олдига ўқувчиларни Ўрта Осиё ва унинг чегарадош қўшни давлатлари билан таништиришни мақсад қилиб қўйди. Кутубхонанинг Справка-библиографрия бўлумининг вазифраси умуман хар бир суралган масала устидан маълумот бериб турушдир. Кунига юзларча киши бу ердан ўзларига аниқ бўлмаган масалалар устидан тўла ва тўғри маълумотлар олиб кетадилар.

Хар бир бўлумда илмий хизматчилар ишлайдилар. Булар маълум план ва топшириқ юзасидан илмий-текшириш ишларини бажарадилар.

Кутубхона дастлаб очилган вақтида 2000 гина китобга эга эди, хозирда кутубхонада бор китобларнинг сони 750 мингдан ошади.

Кутубхонанинг энг бой бўлумларидан бири, хеч шубхасиз, Ўлкани ўрганиш бўлумидир. Бу ерда ўзбек, араб, фрорс тилларида бу кунга қадар бошқа кутубхоналарда бўлмаган жуда қимматлиқ қўлёзмалар бўлуши билан бирга, инқилобгача ва инқилобдан сўнг Шарққа оид рус, инглиз, немис, фррансуз тилларида бўлган барча китоблар бор. Инқилобдан сўнг махаллий халқлар томонидан ёзилган хар хил адабий, илмий китоблар 30 мингга етадир.

Кутубхонага эски китоблар сотиб олиш 1925-нчи йилда бошланди. Шарқшунос Вяткиннинг кутубхонаси, профессор Фитратнинг қўлёзма тарихий китоблари ва нихоят Фан қўмитаси томонидан берилган эски қўлёзма китоблар билан янада мукаммаллашди, бойиди. Хозирги кунда кутубхонанинг бўлуми дунёда ягона бўлган жуда қимматли қўлёзма китобларга эгадир.

Кутубхонада ўқувчиларнинг сони йилданйил ошмоқда. Агарда 1933-нчи йилда кутубхонага кунига ўрта хисоб билан 157 киши қатнағон бўлса, 1934-нчи йилда кундалик ўқувчиларнинг сони 303, 1935-нчи йилда эса 450 кишига етди. Кутубхона эрталабки соат 10 дан кечки соат 10 гача узлуксиз ишлайди. Кутубхонага келувчиларнинг сони дам олиш кунларида янада кўпайиб, баъзан кунига 600700 га етади. Бинонинг кичкиналиги шунча кишига тез хизмат этишга имконият бермаганидан, кишилар навбатга туриб қоладилар. Кутубхонага шунча кўп киши қатнашиға қарамасдан залда жимлик хукм суради. Ўқувчиларнинг ўзлари хам гаплашмасга, залда тинчлик сақлашға ўрганиб қолғонлар.

Илгари вақтларда кутубхонага келган киши ўзи хохлаган китобни каталогдан ахтара

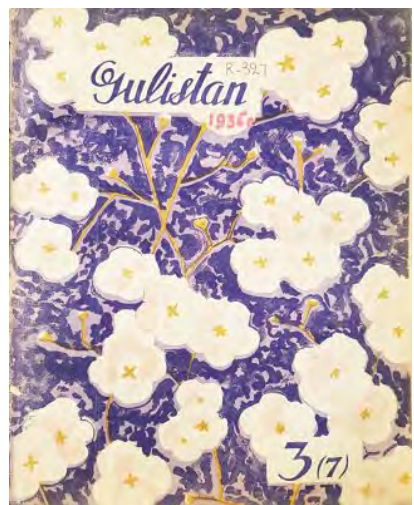

«Эски ва янги илмий адабиёт бойликлари бир марказга тўплаб, ундан фройдаланиш йўлида хизмат кўрсатувчи илмий муассасалардан бири Ўзбекистон халқ Давлат кутубхонасидир. Бу кутубхона 1870-нчи йилда очилган эди

Авваллари, Шарққа оид Оврупо ва Шарқ тилларида бўлган китоблар Шарқ бўлумига ажратилар эди. Бу бўлумнинг вазиораси

ўқувчиларни

Шарққа оид китоблар билан таъмин қилиб туруш бўлса-да, бу вазифани тўла бажара олмаганидан Ўлкани ўрганиш бўлумига айлантирилди 


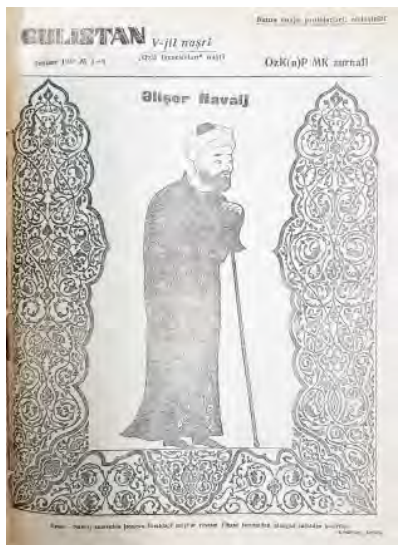

Кутубхонани оммага яқинлаштириш ва унда қилинмоқда

бўлган илмий ишлар билан таништириб туруш мақсади билан 1935-нчи йилдан

бошлаб илмий хизматларни китоб тариқасида чиқариб турулади

Газетанинг 1936 йил 12 май

сонида «Халк

кутубхонаси

тўғрисида» деган мақола чоп этилган бўлиб, унда кутубхона жамғармасида

1 миллион нусха китоб борлиги таъкидланган бериб, жони чиқар ва баъзан уни топишнинг йўлларини билмасдан, бекорга вақтини ўтказиб, қайтиб кетар эди. Кутубхона мана шуни назарда тутиб, бу ишни осонлаштириш учун консултатсия ташкил қилди.

Навбатчи консултант ўқувчиларға каталогдан излаган китобни топиб олишга ва уни қизиқтирғон масалалар хақида қандай нарсалар ўқуш керак эканлигини ўргатиб туради, навбатчи консултантдан ташқари ўқувчиларға ўзлари ечолмаган масалаларни хал қилишға ёрдамлашиб турувчи, шунга доир асарларни кўрсатиб берувчи махсус консултантлар бор. Умумиятли консултатсия ташкил қилиниши, оммани кутубхонага жалб қилишда ва уларнинг китоблардан тўла фойдаланишларига кўп ёрдам берди.

Сўнгги йилларда кутубхона янги китоблар олиш ишини хам жуда кенгайтирди. Фақат 1934-нчи йилнинг уузида 5900 китоб, 2757 та журнал ва саккиз минг дона газет олинди. Шунга нисбатан бу йил кутубхонанинг штати хам ортдирилди. Умумий харажатлардан бошқа, фрақат кутубхонанинг илмий хизматлари учун 35 минг сўм ажратилди. Хозиргача янги чиққан китоблардан бир-икки нусхасинигина олинар эди. Омманинг китобларга талаби кундан-кун ўсмакда бўлгани учун китобларнинг нусхалари кўпайтирилмакчи. Бу йил кутубхона маъмурияти оммани кутубхона билан таништириш ва уларни қизиқтирғон барча китоблар билан таъмин қилиш учун тадбирлар кўрмакда. Баъзан китоб устида қандай ишлаш керак эканлиги хақида илмий лексиялар бўлиб туради. Кутубхонада китобларнинг қандай сақланишини кўрувни истаганлар учун экскурсиялар ташкил қилинади ва экскурсия махалида кутубхонанинг энг бой ва қимматли асарлари кўрсатилади. Бундан бошқа тематик кўргазмалар ва янги адабиёт кўргазмалари ташкил қилиб турилади.

Кутубхонада бўлган ва янги келган китобларни матбуот орқали билдириб туруш хам планга киргизилган. Кутубхонада нўта бўлими хам очилмоқчи. Материал ахтариб келган кишилар нўталарни чалиб кўрушлари мумкун бўлсин учун айрим бир кабинет очилиб, лозим бўлган музика асбоблари билан таъмин қилинмоқчи. Илмий ишлар олиб бориш учун айрим кабинет ва куургазма зали хам ташкил қилинажақ. Кутубхонада бор бўлган хариталарни тартибга солиш ва уларни тўдаларга ажратиб, каталоглар тузуш хам бошланган. Бу иш кутубхонада сақланиб ётган кўп харита хам материалларни очиб беришга ва ишга солишгахизмат қилади.
Кутубхона шу йилнинг кузида ўзининг 65 йиллик юбилейини ўтказиш учун тайёрлик кўрмакда.

Кутубхонани оммага яқинлаштириш ва унда қилинмоқда бўлган илмий ишлар билан таништириб туруш мақсади билан 1935-нчи йилдан бошлаб илмий хизматларни китоб тариқасида чиқариб турулади. Биринчи тўплам юбилей муносабати билан чиқарилажақдир.

Кутубхонанинг юбилейи жумхурият доирасида кутубхонанинг ишларини жонландириш, унинг қимматини ошириш ва уни оммага яқинлаштиришда жуда катта рол ўйнаяжақ».

Яна «Қизил Ўзбекистон» газетасига мурожаат қиламиз. Газетанинг 1936 йил 15 март сонида «Пушкин музикада» номли хабар босилган. Унда айтилишича, 1936 йил 11 март куни Давлат халқ кутубхонасида машхур рус шоири А.С. Пушкин хаёти ва ижодига бағишланган ижодий кеча ўтказилган. Бундан шу нарса маълум бўладики, кутубхонада машхур ёзувчи ва шоирларга бағишланган адабий кечалар хам мунтазам ўтказилиб турилган.

Газетанинг 1936 йил 12 май сонида «Халқ кутубхонаси туғғрисида» деган мақола чоп этилган бўлиб, унда кутубхона жамғармасида 1 миллион нусха китоб борлиги таъкидланган.

Биз яна бир нарсани алохида таъкидлашни истардикки, кутубхона ўқувчиларнинг китобга, мутолаага бўлган қизиқишларини орттириш, илм олишга бўлган интилишларини кучайтириш мақсадида китобга оид турли хил кўргазмалар ташкил қилиб турган. Сўзимизнинг исботи тариқасида газетанинг 1936 йил 21 май сонида чоп этилган «Китобчилик тарихи» номли хабарни келтирамиз. Ундан маълум бўлишича, Тошкент халқ кутубхонасида «Китоб босиш тарихи» деган кўргазма ташкил қилиниб, китобсевар ўқувчилар ихтиёрига хаволақилинган.

Газетанинг 1936 йил 2 август сонида «Давлат кутубхонасининг 65 йиллик иши» номли хабар босилган бўлиб, унда айтилишича, кутубхонада «ЎзССР Давлат халқ кутубхонасининг асарлари» деган тўплам тайёрланган бўлиб, унга 65 йил мобайнида кутубхонанинг иқтидорли ходимлари томонидан ёзилган мақолалар, нашр этилган китоб ва библиографрик кўрсаткичлар киритилган.

Газетанинг 1936 йил 24 август сонида «Нодир қўлёзмалар» деган хабар босилган бўлиб, унда Тошкент Давлат кутубхонаси Бухоро кутубхонасидан 1200 жилд эски қўлёзма асар олганлиги айтилган. Бу бебахо ва дурдона асарлар билан кутубхона фронди яна анча бойиган. 
Газетанинг 1937 йил 1 март сонида «Тошкент халқ кутубхонасининг ўтмишидан» сарлавхали мақола чоп этилган. Унда кутубхонанинг очилишидан то 1937 йилгача бўлган тарихи ёритилган бўлиб, ўтмишига оид айрим лавхалар келтирилган.

1937 йилда «Қизил Ўзбекистон» сахифраларида ўзининг ўлмас асарлари билан жахон илм франи тараққиётига улкан хисса қўшган «шайх ур-раис», «табиблар подшохи» деган фрахрли унвонларга сазовор бўлган буюк мутафаккир ва хаким Абу Али ибн Синонинг (980-1037) вафотига 900 йил тўлиши муносабати билан кўп материаллар эълон қилинган. Тошкент халқ кутубхонасининг малакали ходимлари хам буюк хакимнинг юбилейини муносиб қарши олишган. Бу хақдаги «Улуғ олим юбилейига тайёрлик» деган хабар газетанинг 1937 йил 17 март сонида босилган.

Ўзбекистонда 1938 йил 25 январдан 5 февралгача грузин халқининг улуғ шоири Шота Руставели ўнкунлиги ўтказилган. Давлат кутубхонаси хам бу ўнкунликда фраол қатнашган. 27 январь куни кутубхонада грузин адабиётининг буюк намоёндаси Шота Руставели қаламига мансуб «Йўлбарс терисига ёпинган тўлгани муносабати билан тантанали кеча ўтказилган.

Кутубхона муттасил равишда машхур асарларга бағишланган кўргазмалар ташкил қилиб, адабиёт ихлосмандларини хушнуд қилиб борган. Бунга мисол қилиб, 1938 йил май ойида кутубхонада қадимий рус адабий ёдгорлиги бўлган «Игорь жангномаси»нинг 750 йиллигига бағишланган кўргазма очилганлигини кўришимиз мумкин.

1930 йилларнинг охирларида юртимизда шер Навоий юбилейини кенг миқёсда нишонлаш учун катта тайёргарлик ишлари бошланган. Ўзбек Давлат кутубхонаси хам бу борада бир мунча ишлар қилган. Фикримизнинг таспахлавон» поэмасининг ёзилганига 750 йил улуғ ўзбек шоири ва мутафаккири Мир Али-

диқи сифратида газетанинг 1939 йил 14 май сонида босилган «Тўхтасин» имзоли «Навоий виставкаси» деган хабарни келтирамиз. Унда айтилишича, кутубхонада Алишер Навоийнинг хаёти ва ижодига бағишланган 8 бўлимдан иборат бўлган махсус кўргазма ташкил қилинган. Бу кўргазма хар доим янги хужжат ва адабиётлар билан тўлдириб борилган.

Газетанинг 1939 йил 6 август сонида Юсуфжон Каримийнинг «Ўзбекистон Давлат кутубхонасида» номли диққатга сазовор мақоласи эълон қилинган. Унда муаллиср зиё масканида Ўзбекистоннинг 15 йиллик юбилейи хамда кутубхонанинг 70 йиллиги муносабати билан қилинган илмий ишлар хақида маълумот берган.

Газетанинг 1940 йил 23 октябрь сонида О. Пуулатовнинг газета идорасига йўллаган хати босилган бўлиб, у «Халқ кутубхонасига жиддий эътибор берилсин» деб номланган. Унда Ўзбекистон Давлат кутубхонаси тор ва ноқулай бинода жойлашгани боис яхши фаолият кўрсата олмаганлиги айтилган. Муаллиср мутасадди ташкилотлардан кутубхонага жиддий эътибор беришларини хамда янги бино масаласини тездан хал қилишларини талаб қилган.

Юқорида келтирилган маълумотлар миллатнинг маънавият маскани бўлмиш Ўзбекистон Миллий кутубхонасининг 1930-1940 йилларда кенг халқ оммасига зиё тарқатишдек шарафрли вазифрасини тўлақонли бажарганидан хамда амалга оширган илмий-маърифий ишлари билан мамлакатимизнинг маданий хаётига муносиб хисса қўшганидан далолат беради.

\section{Фойдаланилган адабиётлар}

1. «Қизил Ўзбекистон» газетасининг 1934-1940-йилларда чиқкан сонлари.

2. «Гулистон» журналининг 1935 йил 4сони.

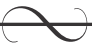

Феруза Нуриддинова - библиограф информационно-библиотечного иентра «TURON» Ташкентской области.

Автор статьи публикует очередной материал, связанный с деятельностью Национальной библиотеки Узбекистана. В ней напечатаны материалы о периодических изданиях 1930-1940 годов и она является продолжением статьи, которая была опубликована ранее о периодике 1920-1930 годов. В этой работе приводятся в основном указатели периодических изданий, один из них «Қизил Ўзбекистон», отражающий 10-летний период, где напечатано 25 материалов под различными рубриками. Автор акцентирует внимание на то, что в 1934 году в газете напечатана статья под названием «Великолепное культурное заведение», связанная со строительством нового здания библиотеки и приводится обзор нового проекта. Также освещено празднование 65-летнего юбилея организации библиотеки, которое было проведено в 1935 году.

\section{Газетанинг}

1937 йил 1 март

сонида «Тошкент

халқ

кутубхонасининг

ўтмишидан»

сарлавхали мақола

чоп этилган.

Унда

кутубхонанинг

очилишидан

то 1937 йилгача

бўлган тарихи

ёритилган бўлиб,

ўтмишига оид

айрим лавхалар

келтирилган

Газетанинг 1940 йил

23 октябрь сонида

О. Пўлатовнинг

газета идорасига

йўллаган хати

босилган бўлиб, у

«Халқ кутубхонасига

жиддий эътибор

берилсин» деб

номланган.

Унда Ўзбекистон

Давлат кутубхонаси

тор ва ноқулай

бинода жойлашгани

боис яхши фраолият

кўрсата олмаганлиги

айтилган 


\section{ЎЗБЕКИСТОН \\ РЕСПУБЛИКАСИНИНГ \\ БИРИНЧИ ПРЕЗИДЕНТИ ЭЛЕКТРОН АРХИВИНИНГ ЯРАТИЛИШИ}

$10.47267 / 2181-8207 / 2020 / 3-038$

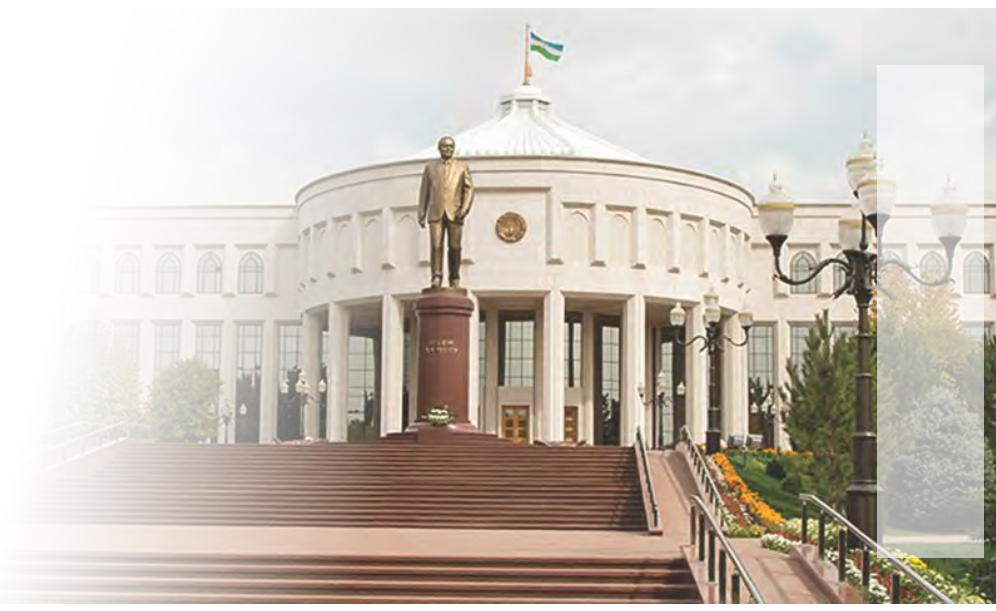

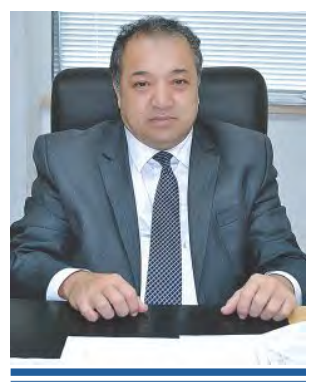

Алишер Ишматов, Ўзбекистон

Республикасининг Биринчи Президенти

Ислом Каримов номидаги

илмий-маърисрий ёдгорлик мажмуаси, рахбарининг биринчи ўринбосари, сризика-математика франлари номзоди, доцент

Вероника Ахмедова Ахборот ва оммавий коммуникациялар агентлиги етакчи мутахассиси

\section{Дилшод Ахмедов} Мухаммад

ал-Хоразмий номидаги

Тошкент ахборот технологиялари

университети

кичик илмий ходими

The article discusses some aspects of the organization of the information system of the Archive of the First President of the Republic of Uzbekistan Islam Karimov. The problem of digitalization of archival activities is quite relevant for Uzbekistan due to the fact that traditional approaches to the construction of information retrieval mechanisms and the organization of information services in archiving today often do not correspond to the required level of efficiency and user needs. As part of the work carried out, the specific task was to organize a software environment for the formation of an electronic catalog of archived descriptions, filling databases of digitized copies of archival materials, as well as flexible multidimensional search and presentation of information. The way to solve this problem is to use the archival information system «AtoM». As a result, a database of digitized archival materials was created, reflecting the life and work of the First President of the Republic of Uzbekistan Islam Karimov, equipped with a developed search and reference apparatus.

Key words: electronic archive, scientific reference apparatus, archival system, archival description, semantic network, AtoM.

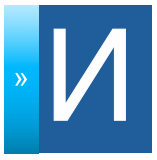

слом Каримовнинг ёдгорлик мажмуаси ораолияти давомида унинг асосий вазифаларини амалга ошириш бўйича бир қатор ишлар амалга оширилди. Хусусан, маълумотлар базасига Ислом Каримов хаёти ва фаолиятига оид хужжатли маълумотлар, китоблар, фротосуратлар, аудио-видео материаллар, эсдалик буюмлари тўпланган. Ушбу коллекциялар ёдгорлик мажмуаси таркибида фраолият кўрсатаётган музей, архив ва кутубхона фрондларининг асосини ташкил этади. Шунингдек, Ўзбекистон Республикасининг Биринчи Президенти хаёти ва фралиятини акс эттирувчи архив материалларини мамлакат тарихининг кенг контекстида рақамлаштириш ва тавсифлаш бўйича ишлар олиб борилмоқда.

Архивнинг ўзига хослиги шундаки, тўпланган тарихий материаллар миқдори билан бирга ахборот савияси жуда юқори. Шу сабабли, тадқиқотчилар фондга мурожаат қилишлари ва уларда аниқланган фрактлар асосида мустақил Ўзбекистон давлатининг шаклланиши ва унинг жахондаги ўрни, янги тарихнинг вужудга келишида ахамияти катта.

Шуни таъкидлаш керакки, хар қандай архивнинг ахборот салохияти фрақат сақлаш жараёнларини тўғри ташкил этиш, хужжатларни тахлилий ва синтетик қайта ишлаш ва маълумотнома-қидирув воситаларини ишлаб чиқиш талаблари бажарилган тақдирдагина амалга ошиши мумкин. Ю.Ю.Юмашева томонидан қайд этилганидек: «Тарихчи-тадқиқотчиларга илмий маълумотнома аппарати (ИМА) архив хужжатлари - тарихий манбаларнинг калити эканлигини тушунтириш керак эмас. ИМАнинг тўлиқлиги, ишончлилиги ва аниқлиги кўп жихатдан керакли манбалар тўпламини аниқлаш имкониятини ва шунинг учун тарихий хақиқатга чиқарилган хулосаларнинг адекватлигини белгилайди. «Айнан архивнинг ИМАси асосий мезон бўлиб, фройдаланувчилар, биринчи навбатда, архив фраолияти самарадорлигини бахолайдилар.

Электрон архив ИМАни ривожлантириш муаммосининг долзарблиги хозирги пайтда ахборот қидириш механизмларини қуриш ва архивлашда ахборот хизматларини ташкил қилиш бўйича анъанавий ёндашувлар кўпинча талаб қилинадиган самарадорлик даражаси ва фройдаланувчи эхтиёжларига мос келмаслиги билан изохланади. Сўнгги ўн йилликларда архивларнинг халқаро амалиётдаги ахборот ишлари сифат жихатидан янги босқичга кўтарилди. Ахборотлаштириш таъсири остида ИМА архив тизимига киритилган маълу- 
мотнома ва қидириш воситалари қурилишинингуслубий асослари хам ривожланди.

Архив муассасаларининг қуйидаги мухим вазифраларини муваффрақиятли хал этиш мухим деб хисоблаймиз. Биринчидан, архив эвристикаси жараёнларини интенсивлаштириш, излаш муаммоларини хал қилиш тезлиги ва самарадорлигини ошириш; фойдаланувчиларнинг хужжатли маълумотларга киришини кенгайтириш (тадқиқотчиларнинг ишини сезиларли даражада мураккаблаштирадиган ИМА сифратининг етарли эмаслигидан келиб чиқадиган чекловларни олиб ташлаш). Иккинчидан, архив хужжатлари, архивлар томонидан кўрсатиладиган турли хил ахборот хизматларидан, шу жумладан шартнома асосида фойдаланиш интенсивлиги ва самарадорлигини ошириш. Учинчидан, ахборот алмашинуви асосида архивлараро ва халқаро хамкорликни замонавий ахборот технологияларидан кенг фройдаланмасдан тасаввур этиб бўлмайди. Шу билан бирга, архивишларини ахборотлаштиришнинг энг мухим йўналиши бу электрон илмий маълумотнома аппаратини яратишдир.

Юқорида айтилганларга асосланиб, уни электрон мухитда тақдим этиш муаммоси ва уни хал қилиш усулларидан бирини кўриб чиқамиз. НСА архивини ривожлантириш билан боғлиқ илмий ва услубий тадбирлар 2018 йилда ўзимизнинг хужжатли маълумотларнинг классификаторини (XМК) яратиш билан бошланди.

ХМК - бу таснисрлаш объектлари номлари ва индекслари рўйхати. ХМК тематик сарлавхаларининг барча даражаларида бўлинишнинг сантиметрлик принципи таъминланади, бу эса, турли хил тушунчалар иерархияси ва бўйсунишини аниқлаш ва ифрода этишга имкон беради. Хозирги вақтда ХМК жадвали фондлар тушунчасига тенг бўлган 12 та асосий бўлимни ўз ичига олади.

Шу билан бирга, ХМК Ўзбекистон Республикасининг Биринчи Президенти Ислом Каримовнинг хаёти ва фраолитини акс эттирувчи архив материалларини рақамлаштириш ва матнли тавсифлаш жараёнида олинган электрон хужжатларни туркумлаш учун ишлатилади.

Демак, архившунослик бўйича анъанавий ИМА фондлар, кичик фондлар тавсифларини ўз ичига олади; ишлар, хужжатларни рўйхатга олиш; саёхатчилар; каталоглар, индекслар ва шархлар, босма ёки хатто ёзма равишда. Ушбу маълумотномалар сақлаш / хисобга олиш бўлинмаларининг таркиби ва мазмуни-

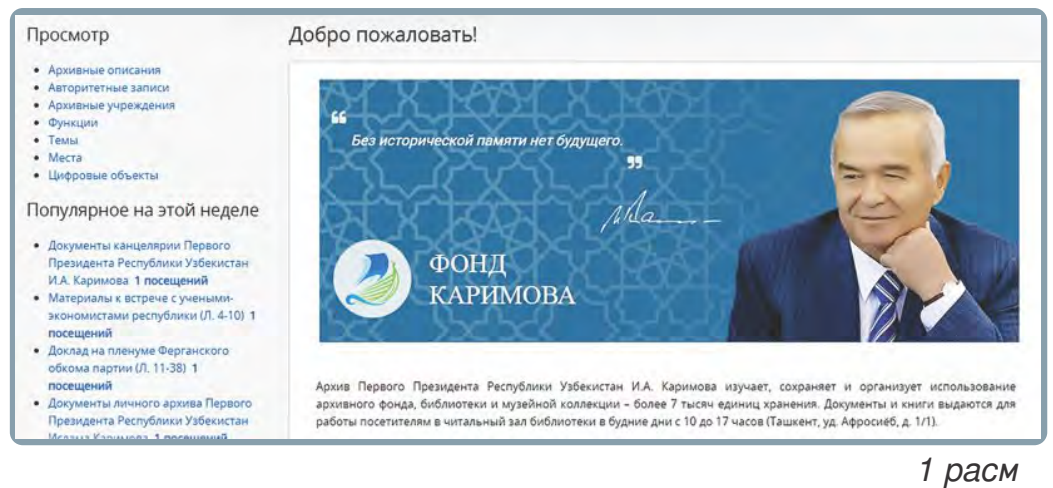

ни очиб бериш, уларнинг жамғарма тизими1 расм даги тизимлаштиришни бирлаштириш учун мўлжалланган. Аммо архивнинг ўзига хос хусусияти шундаки, кўплаб материаллар (сақлаш / хисобга олиш бирликлари) бир вақтнинг ўзида Ислом Каримов музейининг (Музейи) кўргазма экспонатлари хисобланади. Яъни, бу ерда архив сақланиши хар доим хам классик тақдимотга эга эмас - иш папкалари билан жавонлар шаклида. Шу сабабли каталоглар, турли индекслар, шархлар ва қўлланмалар шаклида анъанавий маълумот олиш воситаларидан фройдаланиш мақсадга мувофиқ эмас.

Архив фраолияти концепциясида дастлаб кенг фройдаланувчилар доирасидаги ишлар сақлаш (хисобга олиш) бўлинмаларининг асл нусхалари билан эмас, балки уларнинг аниқ рақамли нусхалари билан, масалан, маълум бир маълумот тизимида, шу жумладан архив тавсифрларининг электрон каталоги ва шу билан боғлиқ медиафайллар кутубхонаси билан амалга оширилади деб тахмин қилинган.

Бундан ташқари, архив материалларини рақамлаштириш ва тавсифлаш бўйича доимий равишда олиб борилаётган ишлар тез орада уларни «қўл» режимда, яъни ихтисослашган ахборот тизимисиз қидириш, тахрирлаш, ишлатиш ва бошқариш жараёнлари ўта ноқулай бўлиб, жуда кўп сонли электрон фрайлларни тўплашга олиб келди.

Шунга кўра, Биринчи Президент Ислом Каримовнинг электрон архивини яратиш ва ривожлантириш муаммоси доирасида қуйидагича аниқ амалий вазисра қўйилди - архив тавсифрлари каталогини шакллантириш жараёнини автоматлаштириш учун дастурий мухитни ташкил этиш (электрон ИМА), архив материалларининг рақамланган нусхаларининг маълумотлар базаларини тўлдириш, кўп ўлчовли мослашувчан маълумотни излаш ва қидирув натижала-рини тақдим этиш.

Ушбу кўринишда биринчи қийин нуқтани тавсифрлаш қоидалари ва кириш нуқталарини стандартлаштириш масаласидир. Кўпгина
XМК - бу таснифлаш объектлари номлари ва индекслари рўйхати.

ХМК тематик

сарлавхаларининг

барча

даражаларида

бўлинишнинг сантиметрлик

принципи

таъминланади,

бу эса, турли хил

тушунчалар

иерархияси ва

бўйсунишини

аниқлаш ва ифода

этишга имкон

беради 
Архив тизимлари

иштирокчилари

уртасида хам ма-

халлий, хам глобал

миқёсда ахборот

алмашинувининг

кучайиши азалдан

ушбу сохада

бир қатор

стандартларни

ишлаб чиқиш

зарурлигини

келтириб

чиқармоқда.

Натижада, халқа-ро архив иши бўйича халқаро архивлар кенгаши хомийлигида ишлаб чиқилган бир қатор стандартлар қабул

қилинди

Ўзбекистонда расмий мақомга эга эмас. Бошқа

томондан,

Ўзбекистонда хам архив тавсифининг барча жихатларини тартибга солувчи

ўзининг ягона норматив-услубий

таъминоти хали мавжуд эмас.

Шу сабабли, архив ишини ташкил

этишнинг халқаро

тажрибасини

хисобга олган

холда ISA халқаро

стандартларидан

фойдаланиш

мақсадга

мувофиқлиги

тўлиқ асосланади архивлар фраол равишда электрон каталоглар ва маълумотлар базаларини яратмоқда. Тўғридан-тўғри кириш имкониятига эга бўлган кўп фойдаланувчи маълумотларини қидириш тизимларининг ишлаши терминология ва ишлатилган сарлавхаларнинг бир хиллигига, хужжатларни тавсифраш қоидаларига, ушбу тавсифнниг алохида элементларини тақдим этиш қоидаларига қатъий талаблар қўяди.

Иккинчи қийинчилик эса, дастурий таъминот билан бевосита боғлиқ бўлиб қолмоқда. Шуни таъкидлаш керакки, умумий қабул қилинган архив тамойиллари ва методологиясини қўллаб-қувватлайдиган, яъни фройдаланувчиларга зарур функцияларни тақдим этадиган ихтисослаштирилган архив дастурлари, албатта, амалга ошириш қийин ва қиммат махсулотдир. Бундан ташқари, дастурий таъминот бозори тахлили шуни кўрсатдики, Ўзбекистонда махаллий ишлаб чиқаришга ихтисослашган архив дастурий махсулотлар мавжуд эмас.

Архивларнинг ахборот тизимларининг ўзаро алоқаси учун архив тавсифи қоидаларини ва алоқа фрорматларини стандартлаштириш масалалари услубий жихатдан бугунги кунда ўз ечимини топди. Гап шундаки, архив тизимлари иштирокчилари ууртасида хам махаллий, хам глобал миқёсда ахборот алмашинувининг кучайиши азалдан ушбу сохада бир қатор стандартларни ишлаб чиқиш зарурлигини келтириб чиқармоқда. Натижада, халқаро архив иши буйича халқаро архивлар кенгаши хомийлигида ишлаб чиқилган бир қатор стандартлар қабул қилинди: ISAD (G) - архив тавсифининг асосий халқаро стандарти; ISAAR - юридик шахслар, жисмоний ва оилалар учун архив хужжатлари ёзувларини яратиш бўйича халқаро стандарт; ISDF функциялар ва маъмурий фраолиятни тавсифлаш учун халқаро стандарт; ISDIAH Архив фрондлари сақловчилари - муассасаларини тавсифловчи халқаро стандарт.

Ушбу стандартларга мувофиқ яратилган архив тавсифлари тўлиқ маълумотларнинг тарихий контекстини ифродалашга ва келиб чиқиш ва асл тартибнинг асосий архив тамойилларини қўллаб-қувватлашга қодир.

Ушбу стандартларни хисобга олган холда архив тавсифрларининг турли хил машинада ўқиладиган коммуникатив форматлари ишлаб чиқилган ва улар ХМЛ специсрикацияларига, асосан, кенг қўлланилмоқда. Энг кенг тарқалганлари қуйидагилардир: EAD - кодланган архив тавсифри формати, $\operatorname{ISAD}(\mathrm{G})$ билан мос келади; EAC-CPF-ISAAR-га муво- фриқ кодланган архив контекст фрормати (CPF); Дублин Cope - кенг кўламли ахборот ресурсларини тавсифрлаш учун метамаълумотларни тақдим этиш фрормати; MODS - бу MARC кутубхонаси форматига содда алтернатив бўлган XML асосидаги библиографик тавсиф орормати.

Шуни таъкидлаш керакки, юқорида кўрсатилган стандартлар Ўзбекистонда расмий мақомга эга эмас. Бошқа томондан, Ўзбекистонда хам архив тавсисрининг барча жихатларини тартибга солувчи ўзининг ягона норматив-услубий таъминоти хали мавжуд эмас. Шу сабабли, архив ишини ташкил этишнинг халқаро тажрибасини хисобга олган холда ISA халқаро стандартларидан фойдаланиш мақсадга мувофиқлиги тўлиқ асосланади.

Архив ахборот тизимининг дастурий таъминотига келсак, юқорида таъкидлаб ўтилганидек, уни сифатли ишлаб чиқиш жуда қимматга тушади. Шу билан бирга, ажралмас шарт - бу доимий дастурий таъминотнинг хаётий циклини ташкил этиш (доимий техник қўллаб-қувватлаш, хатоларини тузатиш, версияни янгилаш ва х.к.), унга хамрох бўладиган экологик тизимни шакллантириш, шунингдек, фройдаланувчиларнинг фраол жамоатчилиги. Амалиётдан кўриниб турибдики, давлат томонидан молиялаштириш хисобига мустақил ривожланиш, кўпинча, самара бермайди.

Яна бир аниқ вариант - хорижда ишлаб чиқарилган тижорат архив дастурлари учун лицензиялар олиш масаласи. Аммо бу ерда хам бир қатор тўсиқлар бор. Биринчидан, лицензиялар жуда қиммат. Қоида тариқасида, дастурий таъминотдан фойдаланиш хуқуқлари чекланган ва вақти-вақти билан пуллик янгиланишни талаб қилади, шунингдек, нарх қанча юқори бўлса, фойдаланувчилар сони шунчалик кўп бўлади. Иккинчидан, архивлар каби маълум бир сохага оид хорижий дастурий таъминот муқаррар равишда муайян иш шароитларига мослашиш ёки хатто жиддий ўзгартириш зарурлигини келтириб чиқаради, бу қўшимча молиявий харажатларни англатади.

Юқоридаги холатларни хисобга олган холда, Архивнинг ўзи ва унинг ИМАни электрон шаклда ташкил этиш масаласини хал қилишнинг таклиф қилинган усули очиқ кодли бепул дастурий таъминотдан фойдаланишдир. Танланган ёндашув бир қа-ор потенциал афзалликларга эга, жумладан:

- бепул, бу интернетдан бепул юклаб олиш ва фройдаланиш, янгилаш, тарқатиш ва бошқалар учун тўловни талаб қилмайдиган ли- 
цензиянинг мавжудлигинианглатади;

- тизимнинг барқарорлигини, функционаллигини ва янада ривожланишини таъминлайдиган ишлаб чиқувчилар ва фройдаланувчиларнинг ривожланган жамоаларининг мавжудлиги;

- бепул лицензиянинг ўз эхтиёжлари учун хар қандай дастурий таъминот модификациясига ўзи ёки хар қандай учинчи томон ишлаб чиқарувчиларини жалб қилиш хуқуқини беришини хисобга олган холда маълум бир ишлаб чиқувчидан мустақилликдир.

Архивсиз бепул дастурий таъминотнинг бир қатор мавжуд намуналарини тахлил қилиш ва синовдан ўтказиш асосида «AtoM» тизими Архив ахборот тизими сифатида танланди. Бу архивлаш жараёнларининг кўп қисмини автоматлаштириш учун очиқ манба, кўп фройдаланувчили веб-дастур: сақлаш бирликларини инвентаризация қилиш, архив материалларини каталоглаштириш, рақамли таркибни қидириш ва кўриш ва бошқалар.

Демак, Биринчи Президент Ислом Каримовнинг Архиви мисолида, хозирги кунда биринчи блокнинг функционал имкониятларидан деярли фройдаланилмайди. «AtoM» мухитидан фройдаланишнинг асосий мақсади ривожланган қидирув ва маълумотнома аппарати билан рақамланган архив материалларининг электрон маълумотлар базасини яратишдир.

Ахборот тизими тақдим этадиган биринчи нарса бу архив материалларининг иерархик тузилишини тавсифлаш қобилиятидир.

1-расм И.А. Каримовнинг электрон архивининг бош сахифасини кўрсатади, ХМКнинг дастлабки икки бўлимига мос келадиган хозирги вақтда мавжуд бўлган юқори даражадаги ёзувлар (фондлар) кўрсатилган. Улардан бирини танлаш фойдаланувчининг навигация режимини очади ва маълум бир хужжатгача тавсифлашнинг кейинги даражаларини кўрсатади.

Архивланган тавсифлар сахифрасининг кўринишини қуйидагича тасвирлаш мумкин. Тўлиқ архив ёзувлари, умумийидан ўзига хосгача кетма-кет тавсифрлаш принципига кўра қуйидагича бўлади:

[Фонд] 01. Биринчи Президент Ислом Каримовнинг шахсий архивидан хужжатлар, $1938-2016$

$\longrightarrow$ [Иш] 03. Хорижий давлатларнинг давлатмукофотлари, 1992-2014 йй.

$\longrightarrow$ [Хужжат] 09. «Фуқаролик хизматлари учун» энг юқори даражали ордени, 2003 й. 2-расм. Архив тавсифри - Ислом Каримов 2003 йилда мукофотланган «Энг юқори даражадаги ффқаролик хизматлари учун» ордени (Испания). Орденнинг рақамли оротосуратлари ва мукофротлаш тўғрисида Фармоннинг нусхаси бўлган электрон фрайлнинг бир қисми.

Фойдаланувчи томонидан орденнинг кичик эскизини босиш, бу эрда орденнинг рақамли фоотосуратлари ва мукофотлаш тўғрисидаги Фармоннинг нусхасини ўз ичига олган архив тавсифри билан боғлиқ бўлган электрон фрайлни кўришга ўтиш имконини беради.

Жамғарма ёзувлари асосий хисобланади ва архив тавсифининг кейинги даражалари келиб чиқувчи ёзувлари хисобланади. Хар бир даражадаги архив тавсифининг тузилиши ва мазмуни бир хил, аммо фрақат ушбу даража учун зарур бўлган элементлар тўлдирилади. Бундан ташқари, юқори даражадаги майдонларда тўлдирилган маълумотлар қуйи даражадаги майдонлар томонидан «мерос қилиб олиниши» мумкин.

Демак, архив материалларини каталоглаштиришнинг юқоридаги функционал имкониятлари уларни идентификаторлар, сарлавхалар, тугаш саналари, фронд яратувчиси ва бошқалар бўйича фрилтрлаш натижалари билан излашга имкон беради. Албатта, бу холда сиз иерархик даражага аниқлик киритишингиз мумкин (фонд - тавсиф-иш).

Боғлиқ луғатларга, мавзули таксономияларга, ваколатли хужжатларга келсак, фройдаланувчи нуқтаи назаридан улар кириш нуқталари сифатида ишлайди. Чап панелда асосий кириш нуқталарини кўриш мумкин, шу жумладан: фонд яратувчилар ва архив омборлари ваколатлари ёзувлари, ташкилий

Архивсиз бепул дастурий

таъминотнинг бир қатор мавжуд намуналарини тахлил қилиш ва синовдан ўтказиш асосида «AtoM» тизими Архив ахборот тизими сифатида танланди. Бу архивлаш жараёнларининг кўп қисмини автоматлаштириш учун очиқ манба, кўп фойдаланувчили веб-дастур

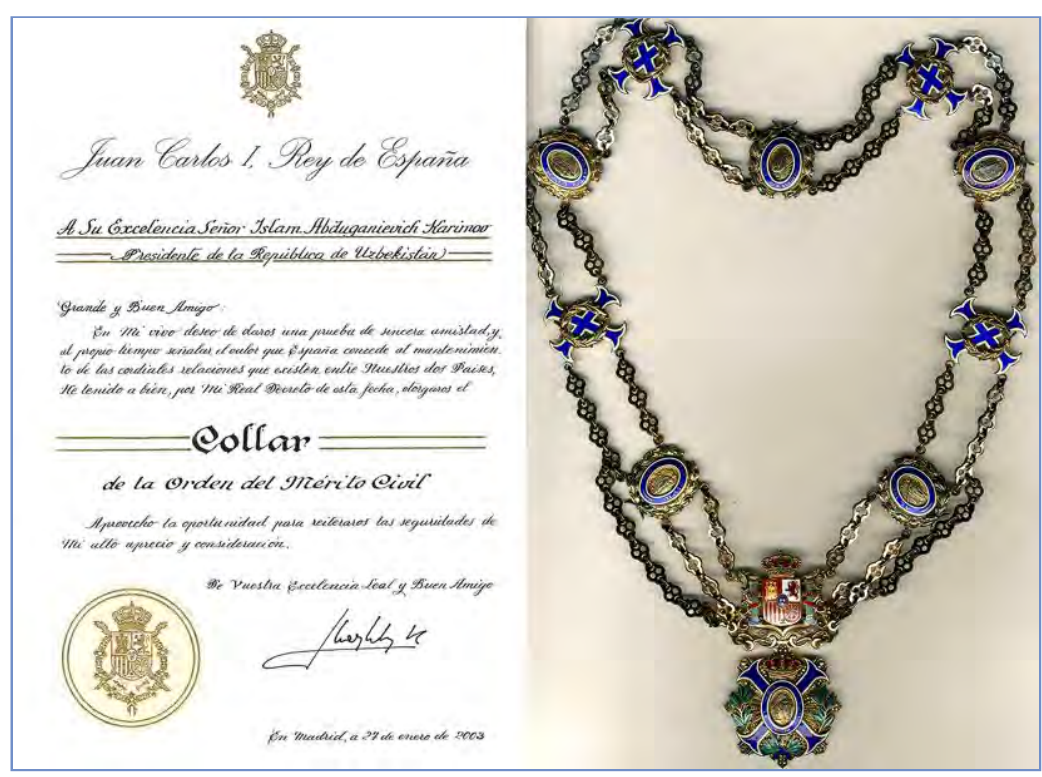


«AtoM» ахборот

тизимидаги

семантик тармоқ

маълумотлари бир

хил сценарийни

шакллантиради,

Бу механизмнинг

асосий қиймати

шундаки,

тадқиқотчилар,

тарихчилар ва

архивчилар Ислом

Каримовнинг

фраолиятига

оид мавжуд

маълумотлардан

хаёт ва хаётга

тегишли хар қандай

янги яққол бўлмаган

билимларни олиш

имконияти билан

таъминланади фуннциялар, мавзу (лар), геограсрик жойлашувлар ва электрон фрайллар.

Албатта, тизим фройдаланувчилари метамаълумотлар матнида, шунингдек тўлиқ матнли хужжатлар таркибида ўзбошимчалик билан қидириш имкониятига эга. Шу билан бирга, ахборот тизими сифратида «AtoМ»нинг тўлиқ салохияти таркибни мазмунли тавсифлаш фрункционал имкониятларидан максимал даражада фойдаланиш билан очиб берилади, бу маълумотни қидиришни интеллектуализация қилишга ва аниқ бўлмаган билимларни аниқлашга имкон беради.

«AtoM», маълумотларни машинада ишлов бериш учун мос шаклда расмийлаштиришга имкон берадиган семантик технологияларни қўллаб-қувватлашни амалга оширади. «AtoM»да кўрсатилган хар қандай субъектлар (архив тавсифрлари, ваколатли маълумотлар, функциялар, атамалар ва бошқалар) ва уларнинг хусусиятлари тўплами йўналтирилган графикани ташкил этадиган баёнотлар тўплами сифратида ифодаланиши мумкин, бунда вертикаллар субъектлар ва объектлар, қирралар эсапредикатлардир.

Электрон архив фойдаланувчиси нуқтаи назаридан семантик тармоқларнинг кўриб чиқилаётган аппарати учун маълум бир дастур фойдаси - бир вақтнинг ўзида насрақат қидирилаётган объект ёки ходиса тўғрисида тор маълумотни, балки сўралган объектга тегишли турли хил маълумотларни хам олиш қобилиятидир.

Айтайлик, фойдаланувчи «Г.В. Плеханов номидаги Россия иқтисодиёт академиясининг фрахрий фран доктори дипломи» номли хужжатни топди ва кўриб чиқди. Кейинчалик, фойдаланувчи ушбу университет яна қандай қилиб Ислом Каримов номи билан боғлиқлигини билишга қарор қилди. Университет номи кўрсатилган хаволани босиш фойдаланувчига тегишли ваколатли ёзувларни кўришга олиб келади.

Кўриб чиқилаётган семантик аппарат «Vi- kipediya» интернет энциклопедиясида ишлатиладиган wiki-grafik технологиясига ўхшайди.

«AtoM» ахборот тизимидаги семантик тармоқ маълумотлари бир хил сценарийни шакллантиради, бу тушунчалар, ходисалар, сабаб-таъсир муносабатлари тўпламидир. Бу механизмнинг асосий қиймати шундаки, тадқиқотчилар, тарихчилар ва архивчилар Ислом Каримовнинг фраолиятига оид мавжуд маълумотлардан хаёт ва хаётга тегишли хар қандай янги яққол бўлмаган билимларни олиш имконияти билан таъминланади.

Хозирги кунда Ёдгорлик мажмуасининг махаллий тармоғида Биринчи Президент Ислом Каримовга яратилган электрон архиви фраолият юритмоқда. Архив материалларининг ўн иккита тўпламини рақамлаштириш ва тавсифрлаш давом этмоқда ва маълумотлар базаси доимий равишда тўлдирилмоқда.

Ўзбекистон Республикаси Марказий давлат архиви мутахассислари иштирокида АтоМ интерфейсини ўзбек тилига тўлиқ локализация қилиш версиясини яратиш бўйича ишлар олиб борилмоқда. Келгусида Ёдгорлик мажмуасининг электрон архиви ва Ўзбекистон давлат архивларининг ташқи ахборот тизимлари, шунингдек, хорижий давлатларнинг архивлари ўртасида ахборот алоқаларини коммуникатив фрорматдаги архив тавсифрларини автоматлаштирилган алмашинуви орқали амалга ошириш режалаштирилган.

\section{Адабиётлар рўйхати}

1. О комплексе [elektron resurs] / Научнопросветительский комплекс Ислама Каримова. URL: https://bit.ly/3dcpmWM (murojaat qilingan sana: 2020.07.10).

2. Nappo C.A. Presidential Libraries and Museums. New York: Rowman \& Littlefield, 2018.262 p.

3. About the Center [elektron resurs]/ The web-site of Heydar Aliyev Center. URL: https://bit.ly/34dMwYp (murojaat qilingan sana: 2020.07.10)

\footnotetext{
Алишер Ишматов - Первым заместителем руководителя Научно-просветительском мемориальном комплексе имени Первого Президента Республики Узбекистан Ислама Каримова.

В статье рассматриваются некоторые аспекты организации информационной системы Архива Первого Президента Республики Узбекистан Ислама Каримова. Была проведена работа по формированию электронного каталога архивных описаний, наполнению базы данных оцифрованных копий архивных материалов, разработке гибкого многоаспектного поиска и представления информации. При решении поставленной задачи была применена архивоведческая информационная система «AtoM» и в результате создана база данных оцифрованных архивных материалов, отражающих жизнь и деятельность Первого Президента Республики Узбекистан Ислама Каримова, оснащенная развитым поисково-справочным аппаратом.
} 


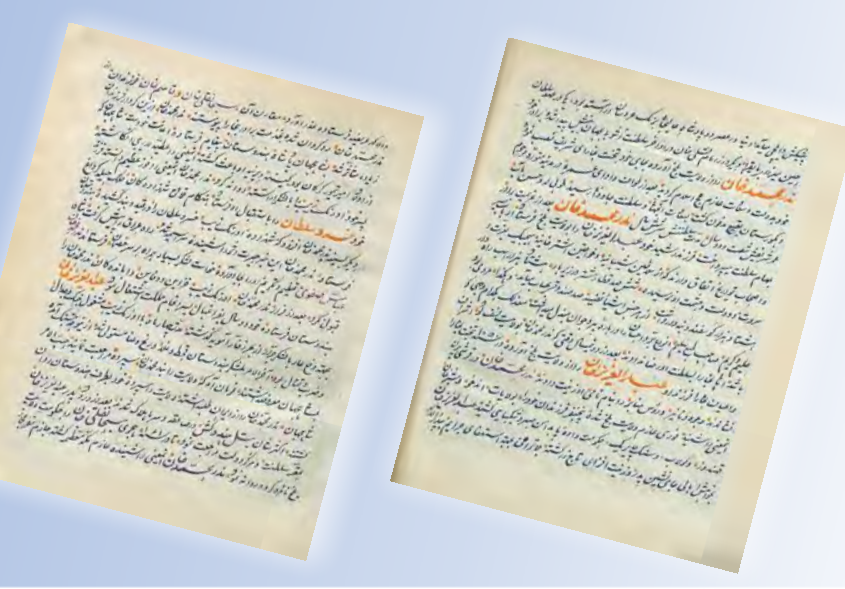

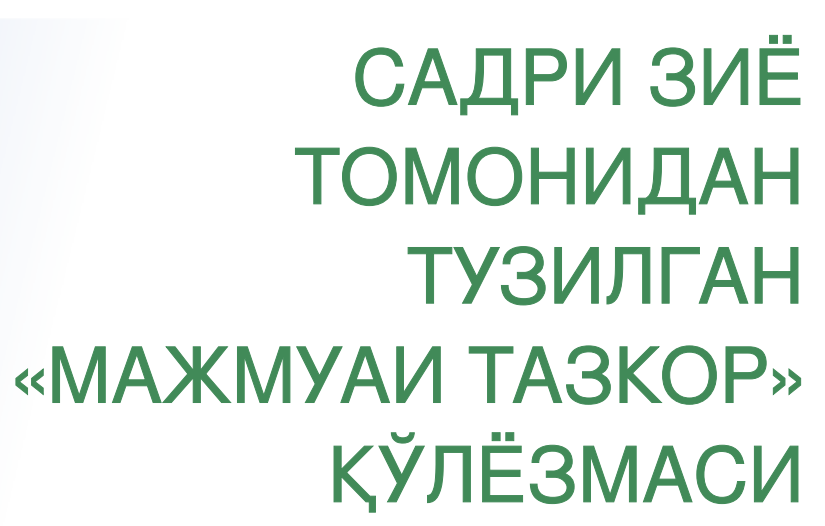

doi 10

$10.47267 / 2181-8207 / 2020 / 3-039$

In this article analyses one of the famous person of Bukhara khanate in the end of XIX - beginning XX century Muhammad Sharif Sadri Ziya and one of his historical heritage, which kept under the number of 2193 of the Oriental Institute of Academy of Sciences of the Republic of Uzbekistan «Majmuai tazkor».

Таянч сўзлар: Садри Зиё, Мирзо Мухаммад Шарифр, Бухоро амирлиги, шахсий кутубхона, «Тарихи Бухоро», «Тазкира ва тарихлар мажмуи», «Наводири Зиёийа», «Осори Зиёия».

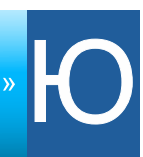
ртимиздаги бой ёзма меросни сақлаш, ўрганиш ва кенгтарғиб этиш ишларини янги сифат босқичига кўтариш, Ўрта Осиё худудидан етишиб чиққан аллома ва мутафаккирларнинг турли сохалар бўйича яратган асарларини тадқиқини кенгайтириш ва чуқурлаштириш хозирда долзарб масалалардан биридир.

Садри Зиё (1867-1932 йй) - XIX аср охири -XX аср бошларидаги Бухоронинг машхур кишиларидан биридир. Унинг исми Шарифожон, қозининг фрарзанди, диндор бўлганлиги учун махдум, садр унвонларини олган, Зиё эса унинг адабий тахаллусидир. Асарларда Садри Зиёнинг номи Мирзо Мухаммад Шариф, Мухаммад Шариф махдум, қози Шарифжон каби ёзилган. У Бухоронинг бош қозиси бўлган Абдушукур садрнинг ўғлидир.

У аввал Бухоронинг Жондор, Карки, Қарши, Ғиждувон туманларида қозилик қилган, кейинроқ яъни Бухоро амирлигининг сўнгги кунларида эса Бухоронинг қози калони эди. Бухоро амирлиги ағдарилиб, Бухоро Халқ Совет республикаси уррнатилгач, турли муассаларда ишлаган. Садри Зиё авлодларга бой мерос қолдиради. Унинг асарлари, асосан, тарихий, адабий характерда бўлиб, Бухоро амирлигининг $\mathrm{XIX}$ аср иккинчи ярми ва XX аср биринчи ярми тарихий, адабий хаёти хақида қимматли маълумотлар беради.

Садри Зиё хаёти ва фраолияти, ижодининг қирралари бўйича унинг замондошлари Хўжа Азим Шаръи, Возих, Афззал Махдум Пирмасти, Абдулла хўжа Абди, Неъматуллох Мухтарам, С.Айнийлар ёзиб қолдиришган. Кейинги даврларда Р.Ходизода Л.М.Епифанова, У Хамроев, Ш.Эсонова, М.Шукуров, Ш.Вохидов ва А.Эркинов, О.Масалиева ва бошқаларнинг асар ва мақолаларида Садри Зиё хаёти ва фаолияти, мероси, кутубхонаси хақида маълумотлар берилган ${ }^{1}$.

1971 йилда хаттот А. Муродовнинг «Ўрта Осиё хаттотлик санъати тарихидан» номли асари нашр этилди. Муаллиф «Бухорода ўтган Олим Шарифржон Махдум ўз асарида қўлёзма манбаларига суянган холда қисман Хирот хаттотлари, асосан, Бухоро хаттотлари фраолияти санъати ва кўчирган китоблари хақида маълумот беради» деб ёзади ва китобида ундан фойдаланади.

Садри Зиё катта шахсий кутубхонага эга бўлган. 1999 йилда унинг кутубхонасининг каталоги Ш.Вохидов ва А.Эркиновлар томонидан Францияда «Cahiers d Asie Centrale» ${ }^{3}$

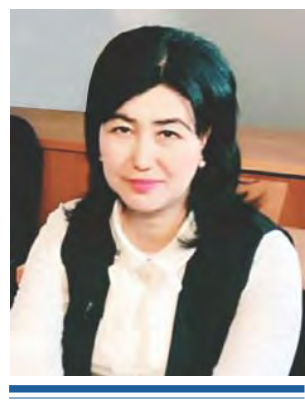

Олтиной Масалиева, Ўзбекистон давлат жахон тиллари университети Тарих кафредраси доценти, тарих франлари номзоди

Садри Зиё катта шахсий кутубхонага эга бўлган. 1999 йилда унинг кутубхонасининг каталоги

Ш.Вохидов ва

А.Эркиновлар томонидан Францияда «Cahiers d Asie Centrale» журнали сахифраларида ва 2007 йилда Тошкентда рус тилида чоп этилади унинг каталоги хақида // Научные труды и сообщения. Кн.6. 1963.Б. 387-396 Шукури М. Садри Бухоро. Техрон. 1380 (форс тилида); Эсонова Ш.Садр Зиёнинг «Рўзнома» асари тарихий манба сифатида // Ўзбекистон тарихига янги чизгилар. Даврий тўплам. -Т.,1999.№1.-74-83;

2 Муродов А.Ўрта Осиё хаттотлик санъати тарихидан. -Т.:Фан,1971. -Б.94.

${ }^{3}$ Vohidov Sh., Erkinov A. Le fihrist (cataloque) de la biblioteque de Sadri Ziya: une image de la vie intellectuelle dans le Mavarannahr (fin XIXe-deb. XXs) // Cahiers d Asie Centrale. 1999.p.141-174. 
М.Шакурийнинг ёзишича, Садри

Зиёнинг илмий меросини тадқиқ этган мархум

Сахобиддин Содиқ

тадқиқотидан

маълумки,

Садри Зиёнинг

60 та асарига

тажовуз қилинган

ва хозир эса,

ўн бир жилди

мавжуд, аксарияти

Садри Зиёнинг

қўли билан чиройли

хуснихатда ёзилган

китоблардир

Садри Зиё Бухоро амирлигида

турли

лавозимларда

ишлаган ва

ўзи ёзган

асарларидаги

воқеаларнинг

иштирокчиси ва

гувохидир.

Шу жихатдан

хам унинг

асарларининг

қиммати юқоридир журнали сахифраларида ва 2007 йилда Тошкентда рус тилида чоп этилади 4 .

Тарихчи олим Ш.Вохидовнинг ёзишича, тожикистонлик олим С.Сиддиқов Садри Зиё илмий меросини ўрганиб, «Садри Зиё ва унинг тазкираси» номли монография тайёрлаган, лекин муаллифнинг 1993 йилда вафот этганлиги сабабли у нашр этилмай қолган ${ }^{5}$.

Академик Мухаммаджон Шукуров томонидан Душанбе шахрида «Садри Бухоро» асари тожик тилида нашр этилади. Шу муаллиф томонидан Техронда «Рўзномаи Садри Зиё» асари яъни Садр Зиёнинг «Рўзнома» асарининг форсча нашри эълон қилинади ${ }^{6} .2002$ йилда шу муаллиф томонидан Техронда яна Садри Зиёнинг «Тазкорэ ашъор» асари нашр этилади.

Садриддин Айнийнинг ёзишича, Садри Зиё ўз даврининг тараққийпарвар ва илғор кишилари - Ахмад Дониш, Исо Махдум, Иноят махдум, Яхё Хожи, қори Абдулмажид Зуфунин, мулла Шариф Соат, Мирзо Азим Сомий, Мухаммад қори Рахматуллох Возех, Шамсиддин махдум Шохин, Хайрат каби кишилар билан яқин алоқада бўлган ${ }^{7}$.

Садри Зиёнинг уйи илмлилар тўпланадиган марказ эди. У Ахмад Дониш, Шамсиддин Шохин, Рахматуллох Возех, Муфти Акром (Домулла Икромча), Мирзо Хаёт Сахбо, Мирзо Азим Сомий, Садриддин Айний, Абдулвохид Мунзим, Ахмаджон Хамидий ва бошқаларни турли хамла ва хужумлардан жасорат билан химоя қилади ${ }^{8}$.

Унинг қуйидаги асарлари мавжуд: «Зикри авоил Бухоро» (Бухоро зикрининг бошланиши), «Тарихи Бухоро», «Мунтахоб ат-таворих», «Рисолаи салотин ва шахриёрон», «Зикри подшохон ва князон давлати Русия», «Зикри холат Чингизхон», «Силсилаи салотин ўзбек Чингизхоние», «Зикри салотин манғитийа», «Зикри салотин ва подшохи амир Олимхон мхолуи», «Мажмуаи тазкор ва таворих»
(Тазкира ва тарихлар мажмуи), «Рўзнома», «Зикри салтанати подшохони манғитийа дар Мовароуннахр»(Мовароуннахрдаги манғитлар подшолиги салтанати зикри), «Мажмуаи тарих» (Тарих мажмуаси), «Наводири Зиёийа» (Садри Зиёнинг нодир манбалари) вах.к.

М.Шакурийнинг ёзишича, Садри Зиёнинг илмий меросини тадқиқ этган мархум Сахобиддин Содиқ тадқиқотидан маълумки, Садри Зиёнинг 60 та асарига тажовуз қилинган ва хозир эса, ўн бир жилди мавжуд, аксарияти Садри Зиёнинг қўли билан чиройли хуснихатда ёзилган китоблардир 9 .

Ш.Вохидов ва 3.Чориевлар, «Мухтарам, Садриддин Айний ва Расул Ходизоданинг маълумотларига таяниб, биз Садр Зиёнинг асарларининг сони 72 тага етадиган (Рўзнома ва Наводири Зийаийани хасобга олганда) тўлиқ рўйхатини тузишга мувафрфақ бўлдик», деб ёзади ${ }^{10}$.

Садри Зиё асарларида кўпроқ атрофида содир бўлган воқеаларни ёки эшитганларини қаламга олган. Масалан, 2367-рақамли қўлёзмада Бухоро амирининг Русияга қилган сасрари тасвири, Бухоро ва Асрғонистон муносабатлари тўғрисида, ўз аризаси намуналари ва бошқалар ёзилган. 1904 йилда бу китобни пароканда холатда топишади ва китоб «Осори Зиёия» деб номланди. Унинг асарлари, асосан, тарихий, адабий характерда. Лекин унинг Бухоро амирлиги тарихи бўйича яратган асарлари хали тўлиқ тадқиқ этилмаган ва илмий истеъмолга киритилмаган. Садри Зиё Бухоро амирлигида турли лавозимларда ишлаган ва ўзи ёзган асарларидаги воқеаларнинг иштирокчиси ва гувохидир. Шу жихатдан хам унинг асарларининг қиммати юқоридир.

1921 йилда Бухоро арки тарихини чуқур уррганиш учун тузилган Бухоро тарихий жамияти комиссияси таркибига Саид Мухаммад Содиқ, Мухаммад Шариф Зиё, Мухаммад Салимбек, Саид Мухаммад Носир ва бошқалар

${ }^{4}$ Вохидов Ш., Чориев З. Садр-и Зия и его библиотека (из истории книги и книжной культуры в Бухаре в начале XX века). Книга 1. Ташкент. «Yangi asr avlodi». 2007.182 s.

${ }^{5}$ Қаранг. Вохидов Ш. Из истории частных библиотек в Бухарском эмирате конса XIX - начале XX вв.(Опыт реконструксии частных библиотек в Бухаре и Шахрисабзе) // Iranname.2012. №2.s.261-284.

${ }^{6}$ Рўзномаи Садри Зиё. Вақое нигори тахавулоти сийоси ижтимоий Бухорои шариф. Тахқиқ ва пежухеш Мухаммаджон Шакури Бухорои. Техрон.1382.500 (форс тилида).

Хамроев У. Бир шахсий кутубхона ва унинг каталоги хақида // Научные труды и сообщения. Кн.6. 1963. б.387.

${ }^{8}$ Рўзномаи Садри Зиё. Вақое нигори тахавулоти сийоси ижтимоий Бухорои шарифр. Тахқиқ ва пежухеш Мухаммаджон Шакури Бухорои. Техрон.1382. Б.35. (фрорс тилида).

${ }^{9}$ Рўзномаи Садри Зиё 21-бет

${ }^{10}$ Вохидов Ш., Чориев З. Садр-и Зия и его библиотека (из истории книги и книжной культуры в Бухаре в начале XX века. с.22. 
кирган ${ }^{11}$. Бу хақда Саййид Мухаммад Носир бин Музафрфар қуйидагича ёзади: “жумхурият шуроси томонидан биз - етти насрар кишини, яъни Хожи Мулло Абдурауср асранди «Фитрат», Саййид Мухаммад Сиддиқ, жаноб қози ул-қуззот, олам ахли муллозодаси домулло Мухаммад Шариф Зиё, Мулло Салимбек, жаноб Хожи Мулло Саййид Махмуд мусртий ва бу фрозиллар хизматкори Саййид Мухаммад Носир «Анжумани тарих» («Тарих анжумани») аъзолари сисратида хар куни арки олийга бориш ва унинг ободлигию вайроналиклари сабаблари борасида олий мадрасада тадқиқотлар ўтказишга тайинланган эдик»

Шарифржон махдум Садри Зиё томонидан тузилган, араб-тожик тилидаги «Мажмуаи тазкор" асари Ўзбекистон Республикаси Фанлар академияси Шарқшунослик институти қўлёзмалар фрондида 2193 рақами остида сақланади. Асар насталиқ хатида чиройли хуснихат билан ёзилган. Хижрий 1342-1347/ милодий 1923-1928-29 йилларда тузилган. 459 варақдан иборат. Асар хақида шарқ қўлёзмалари тўпламининг тарих жилдида қисқача тавсифрланган ${ }^{13}$. Тўпламнинг дастлабки варақларида рус-тожик луғати берилган. «Мажмуаи тазкор» Ўрта Осиё тарихи, адабиёт ва бошқа фран сохалари буйича мухим маълумотларни жамлаган.

Қўлёзмада баъзи мухим саналган асарлардан кўчирмалар мавжуд. Масалан, Жомийнинг «Ал-мақомат Абул бақо», Бухоро шахри тарихи, Наршахийнинг «Бухоро тарихи» қисқача баёни, Носириддин бин амир Музасрфрарнинг «Ходи аз-зоирийн» асари, «Рисола дар байани шахри Нурата», «Алам ал-ахбор" ва Алоуддин Аттор хақида Хорун ар-Рашид билан ёзишмалар ва бошқалардан кўчирмалар мавжуд.

Мажмуада «Мунтахоби салотин ва шахриёрон», «Мунтахоб ат-таворих», «Мунтахаб дар таъйин ва табаййуни балади машхура», «Чингизхон ва унинг ворислари қисқача тарихи", «Силсилаи салатини узбеки чингизийа», Абулхайрхондан бошлаб сўнгги Бухоро амири Олимхон давригача бўлган давр тарихи яъни шайбонийлар, аштархонийлар, манғитлар

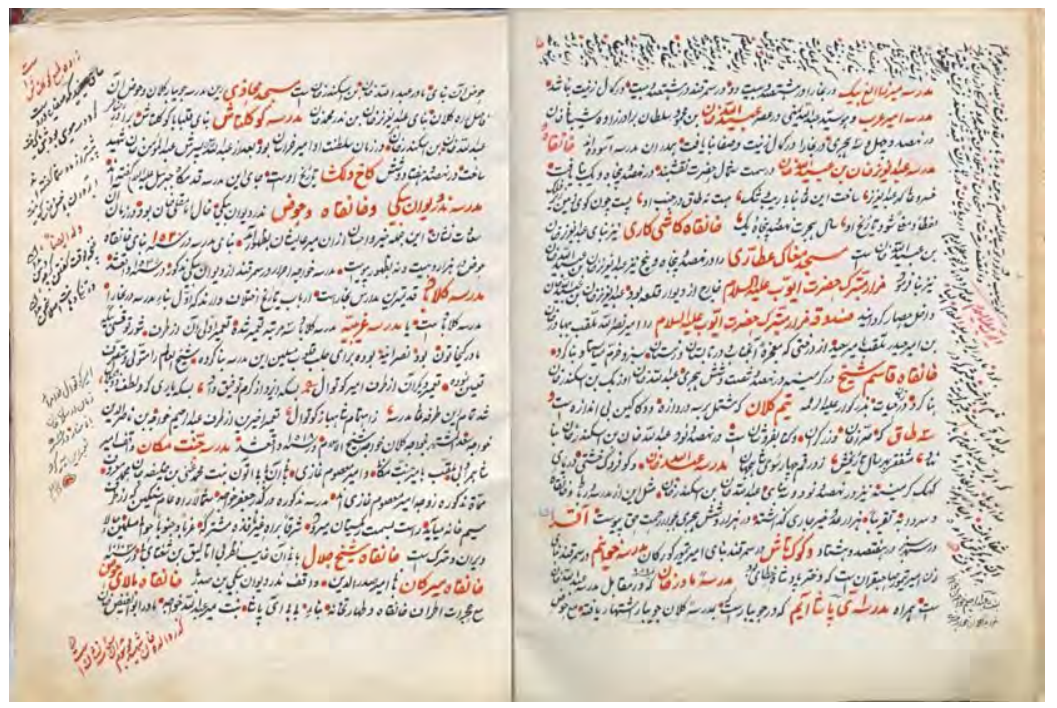

даври тарихи алохида ажратилиб ва Бухорода советлар хокимиятининг ўрнатилиши, Эрон, Усмонийлар Туркияси, Асрғонистоннинг қисқача тарихи, Россия ва унинг князликлари тарихи хам ёзилган.

Мажмуада «Рисолаи хаттотини насталиқи», «Тазкирайи шуарои мутақаддимин ва салотини муъасирин» хам берилган. Қўлёзмада «Рисолаи хаттотини насталиқи»да кўпроқ Бухорода фраолият юритган насталиқ ёзувида ёзган хаттотлар хақида маълумот берилади ${ }^{14}$. Мажмуада Абдулқодир Жилоний ва унинг издошлари, хатлари хақида биограсрик маълумотлар, Фаробий, Ибн Сино, Носириддин Тусий ва бошқаларнинг таржимаи холи хам берилган.

Ушбу қўлёзмада барча давлат ва маъмурий лавозимлар баён этилган. Муаллиср «ўзбек султонларининг ва амалдорларининг мансаблари хақида Чингиз замонларидан буён амалда бўлган мансаблар тилга олинади. Уламолар, улуғлар ва булардан бошқа хукмдорлар тўрт гурухга бўлинади...» ${ }^{15}$, деб ёзади. Қўлёзмада мансаблар саккизта даражаларга ажратилган. Энг олий лавозим қозилар мансаби бўлиб, улардан энг олийси шайх ул-ислом эди, кейингилари қози ал-қуззот, қози аскар, вилоят қозиси ва х.к.

Умароларнинг мансабларига оталиқ киритилган бўлиб, унинг вазифраси Бухорои шариср сувининг идораси, Самарқанддан Қора-

\section{Садри Зиё}

томонидан тузилган, араб-тожик тилидаги

«Мажмуаи тазкор» асари Ўзбекистон Республикаси Фанлар академияси Шарқшунослик институти қўлёзмалар срондида сақланади. Acap 1923-1928-29 йилларда тузилган бўлиб, Ўрта Осиё тарихи, адабиёт ва бошқа фран сохалари буйича мухим маълумотларни жамлаган

${ }^{11}$ Лунин Б. В. 20 - 30 йилларда Ўзбекистонда этнографрия масалаларининг ўрганилиши // XX аср дастлабки ўттиз йиллигида Ўзбекистонда тарих фани. -Б. 314.

${ }^{12}$ Саййид Мухаммад Носир ибн Музафрфар. Тахқиқоти арки Бухоро. Форс тилидан таржима, сўзбоши, изохлар ва кўрсаткичлар Ғ.Каримовники.-Т., 2009. -Б.11-12.

${ }^{13}$ СВР. История. № 257.

${ }^{14}$ Садри Зиё. Мажмуаи тазкор. $248^{\mathrm{a}}-269^{6}$ варақлар.

${ }^{15}$ Садри Зиё. Мажмуаи тазкор. ЎзР ФА ШИ қўлёзмалар фонди,инв. № 2193. 231а-бет. 


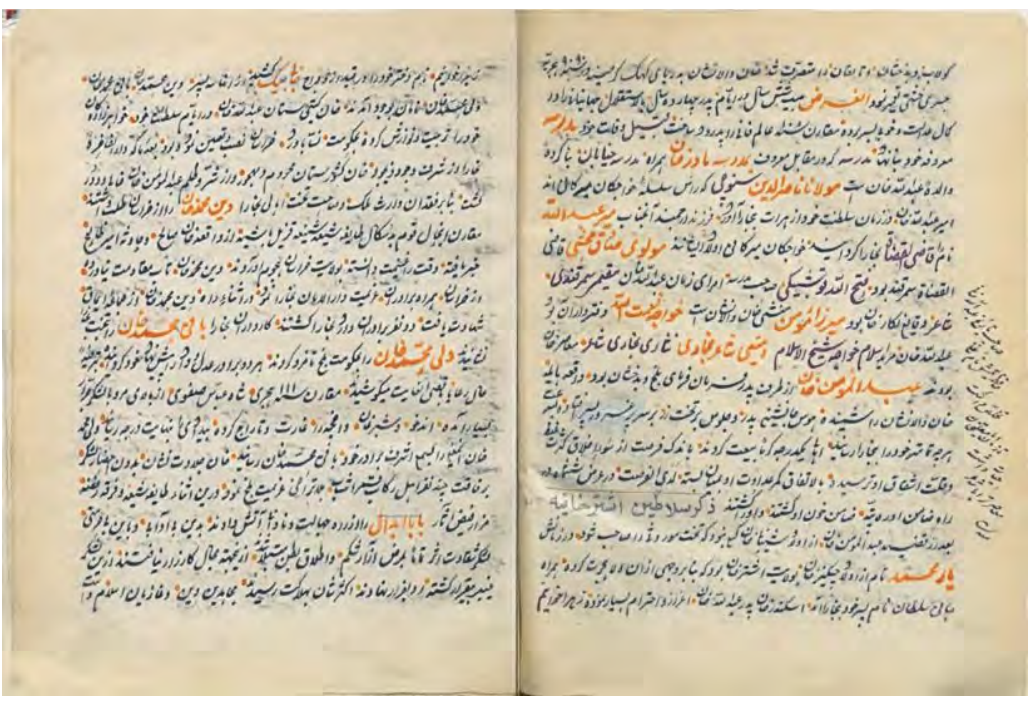

кулгача бўлган сув тақсимоти унинг қўлида эди. Бухоро мироблиги ва доруғалигига хам у қарар эди.

Шуни алохида таъкидлаш жоизки, мустаМустақиллик қиллик йилларида давлатчиликнингўзигахос йилларида белгилари - Бухоро давлатининг бошқарув давлатчиликнинг тизими, амалда бўлган қонун-қоидалар, лавоўзига хос зим ва маросимларнинг жорий этилиш тартибелгилари - Бухоро давлатининг

бошқарув тизими, амалда бўлган қонун-қоидалар,

лавозим ва

маросимларнинг жорий этилиш

тартиби ва

шу кабилар кўп

олимлар диққатини жалб этди би ва шу кабилар кўп олимлар диққатини жалб этди ${ }^{16}$.

Шарқшунос олима Д. Валиева «1948 йилда А.А.Семенов Мирза Бадиъ девон қаламига мансуб бўлган трактатни чоп этади. Аслида, у Шарифржон махдум тузган мажмуадан олинган. Кейинчалик мазкур трактат «Мажма аларкам»нинг тўла нашрига хам илова қилинди», - деб ёзади".

А.Б.Вильданова «Мансаб ва унвонлар тўғрисидаги Бухоро трактатининг асл нусхаси ${ }^{18}$ номли мақоласида Душанбе Халқ кутубхонасида 649 рақами остида «Мажма ал-арқом»(1б-86 б) нинг автограср нусхаси ва юқорида эслатилган трактат (87a-96 а) хам мавжудлиги хақида хабар беради. Муаллисрнинг ёзишича, трактат тили ва услуби «Мажма аларқом» билан умумий ва махсус терминлар- дан фройдаланганида уларни изохлаш учун ууқувчини «Мажма ал-арқом»га мурожаат қилишга йўналтиради. Трактат муаллифрининг ўзи уни илова (тазйил) деб ёзади.

А.Вильданова китобнинг муаллисри Мирза Мухаммад Бадиъ - девон эканлигини ёзади. Шунингдек, уларнинг асл нусхаси А.А.Семенов таржимасидаги матн қисмидаги етишмаган жойларини тўлдиради, А.Семенов тушунмаган баъзи жойларини тушунишга ёки бошқача тушунишга имкон беради ${ }^{19}$ деб ёзади.

Манбашунос олим Ш.Вохидов А.А.Семёновнинг таржима асари, кейинроқ олима Б.Вильданова томонидан нашрга тайёрланган Мирза Бадиъ Девоннинг «Мажма ул-арком» асосида Бухоро амирлигидаги унвон ва мансабларни ўзбек тилига таржима қилиб, чоп эттиради ${ }^{20}$.

Америка Қўшма Штатлари Индиана университетидаги марказда фраолият юритган Ю.Брегель сўнгги тадқиқотида оталиқ ва қўшбеги атамаларига ва уларга эга бўлган шахслар хақида батафрсил тўхталади ва Мирза Баъди Девон афртидан, «Тазйил»нинг муаллифри эмас, деган хулосага келади.

Мазкур хулосани яна германиялик олима Анке фоон Кюгельген асарида хам учратдик. Иккала муаллиф хам «Тазйил»да оталиқ ва қушбеги мажбуриятларининг тавсифи ғалати, деган фрикрга келишган. Уларнинг фикрича, қушбеги XVIII асрда вазир даражасига кўтарилган, Ю.Брегель «Мажма ал-арком муаллисри «Тазйил» яъни иловани қадимийроқ тўпламлардан шунчаки кўчириб олган, афрсуски, бу тўплам бизгача етиб келмаганлиги учун уни қайта текшира олмаймиз " ${ }^{21}$, деб ёзган.

Юқоридаги фрикрлардан хулоса қилиш мумкинки, Садри Зиё хам унвон ва мансабларга оид маълумотларни қадимийроқ китобдан кўчирган, чунки Садр Зиё яшаган даврда оталиқ лавозими амалда мавжуд эмас эди ва қўлёзмада кўрсатилган оталиқнинг вазифа-

\footnotetext{
${ }^{16}$ Сагдуллаев А., Аминов Б. Ўзбекистон тарихи: давлат ва жамият тараққиёти. 1-қисм. - Тошкент: Академия, 2000. - 208 б; Мукминова Р., Агзамова Г. Бухоро хонлиги (амирлиги). // Ўзбекистон давлатчилиги тарихи очерклари. - Т.:Шарқ, 2001. - 106 б; Вохидов Ш., Холиқова Р. Марказий Осиёда давлатчилик тарихидан.-Т., 2006.

17 Масалиева О. Бухоро хонлиги тарихи мустақиллик даври тарихшунослигида // ЎЗМУ хабарлари. Тарих туркуми. Махсус сон. 2013.-Б.127-129.

${ }_{18}^{18}$ Вильданова А.Б. Подлинник бухарского трактата о чинах и званиях // Письменные памятники Востока.-М., 1968. - С. 40-45.

${ }^{19}$ Вильданова Подлинник бухарского трактата о чинах и званиях // Письменные памятники Востока. -Б.41.

${ }^{20}$ Вохидов Ш. Қўқон хонлиги ва Бухоро амирлигида унвон ва мансаблар. -Т., 1996. - 32 б.

${ }^{21}$ Bregel.Y. The administration of Bukhara under the Mangits and some Tashkent manuscripts.(Papers on Inner Asia.№34). - Bloomington, 2000.-P.17.
} 
лари бу даврга келиб қушбегининг зиммасида эди.

Биз учун қўлёзмадаги маълумотлар жуда мухим, чунки мазкур маълумотлар асосида Бухоро хонлигидаги мавжуд бўлган унвон ва мансаблар, уларнинг вазифа ва ваколатлари хақида билиш имконини беради.

Хозирча Бухоро хонлигидаги унвон ва мансаблар тўғрисида тўлиқроқ маълумот берувчи бундан бошқа тарихий қўлёзмалар маълум эмас. Шунингдек, мазкур қўлёзмада туманлар ўртасида сув тақсимоти хақида маълумот берилган. Масалан, Унда Кармина, Шофрурком, Комот ва Сомжин, Хайробод ва бошқаларга қанча равоқ сув берилиши кўрсатилган. Мазкур қўлёзмада яна мадрасалар хақида хам маълумот берилади².

Қўлёзмада «Тарихи осори атиқаи ва бинохои қадимия Бухорои шарифр мавзуидаги Бухоронинг қадимий бинолари тўғрисидаги маълумотлар хам мухим. Шунингдек, мажмуада Бухоро, Самарқанд, Шахрисабзда бунёд этилган баъзи бинолар тарихи хақида қисқача баён этилган. Унда Мирзо Улуғбек мадрасаси, амири Араб мадрасаси, Абдулазизхон бин Убайдуллохон мадрасаси, Абдуллахон мадрасаси, Жўйбори Калон мадрасаси, Дилкушо мадрасаси, Надр девонбеги мадрасаси, хонақохи ва ховузи, Хожа Ахрор мадрасаси, Қосимшайх хонақохи, Калон мадрасаси ва Х.К.лар тўғрисида маълумотлар мавжуд.

Зиёрат туризмига эътибор кучайган бир даврда асардаги маълумотлар жуда мухим. Тўпламдаги маълумотлар асосида Бухоро, Самарқанд ва бошқа жойларда қурилган бинолар, уларнинг тарихи, жойлашган уурнини аниқлаш мумкин. Сабаби асрлар давомида баъзи биноларнинг номи ўзгартирилган ёки вайрон бўлган ва ўрнига бошқа бинолар қурилган бўлиши мумкин.

Қўлёзмада Абдулазиз бин Убайдулла хон хижрий 950 йилда хазрат Нақшбанднинг шимолида бино қилинганлиги хақида маълумот берилган.

Қосимшайх хонақохини Карманада хижрий 960 йилда Абдуллахон ўзбек бин Искан-

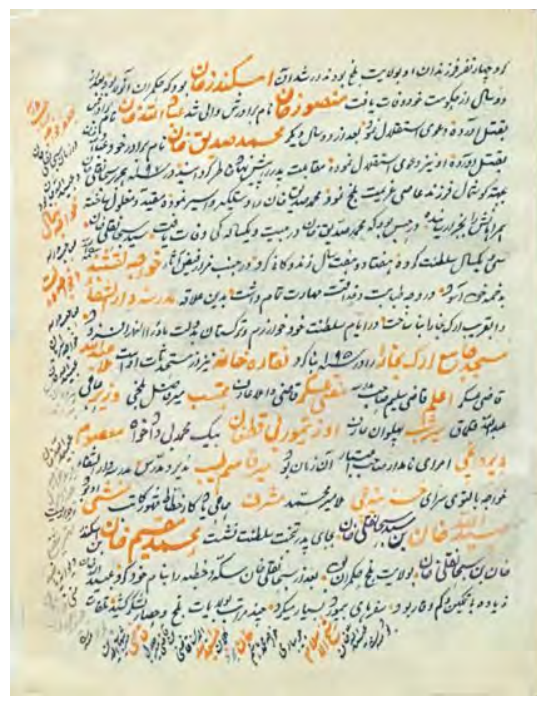

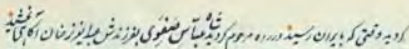

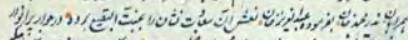
年 is 1)

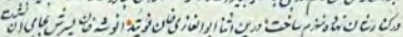

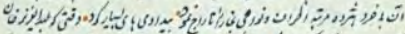

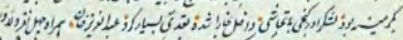

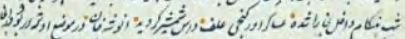
穴

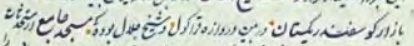

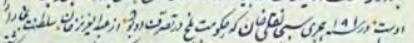
لـ ;

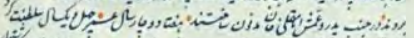

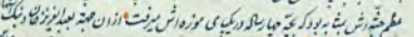

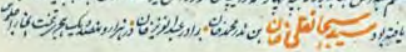

дархон қурдирганлиги ёзилган. Асарда кейинги давр китобларида такрорланиб келган жумлаларни хам учратдик «Абдуллахон бин Искандархон худди шу сингари мадраса, работ, хонақох, сардобалардан мингтача қурдирди».

Асарда Калон мадрасаси Бухоронинг қадимийроғидир, дейилади. Шунингдек, Калобод мадрасаси Бухородаги биринчи эканлиги тўғрисида тарихчилар орасида ихтилофлар бор, деб маълумот берилган.

Тарихимизнинг ўқилмаган сахифаларини қайта тиклашда юқоридаги каби маълумотлар жуда мухим ахамиятгаэга.

Қўлёзмада маълумотлар келтирилар экан, масалан, Наршахийнинг айтишича, Мушфиқийнинг келтиришича каби ибораларни хам қўлланганлиги, хар бир янги мавзуни алохида ажратилганлиги, тарихий шахслар, жой номларининг бошқа рангларда ажратиб ёзилганлиги хамда тарих, адабиёт ва бошқа сохалар бўйича маълумотларни бир жойга жамланганлиги билан хам қимматли.

Садри Зиёнинг мазкур мажмуасини ёзар экан, нодир асарлардаги маълумотлар оммага етиб боришига ва чиройли санъат асари даражасидаги хаттотлик ишига катта хисса қўшган десак асло муболаға бўлмайди. маълумотлар асосида Бухоро, Самарқанд ва бошқа жойларда қурилган бинолар, уларнинг тарихи, жойлашган ўрнини аниқлаш мумкин. Сабаби асрлар давомида баъзи биноларнинг номи ўзгартирилган ёки вайрон бўлган ва ўрнига бошқа бинолар қурилган бўлиши мумкин
Тўпламдаги

Олтиной Масалиева - доцент кафедры истории Узбекского государственного университета мировых языков, кандидат исторических наук.

В статье анализируется один из известных деятелей Бухарского ханства кониа XIX начала XX века Мухаммад Шариф Садри Зия и одно его историческое наследие, хранившееся под номером 2193 Института Востока Академии наук республики Узбекистана «Маджмуаи тазкор».

\footnotetext{
${ }_{22}^{22}$ Масалиева О. Хотин-қизларнинг ўрта асрлардаги тарихий жараёнда тутган ўрни // Илм-фран тараққиётида олима аёлларнингуурни. Илмий-амалий анжуман материаллари. -Т., 2005. -Б. 233 -235.
} 


\section{МУСУЛЬМАНСКИЕ}

СВЯТЫНИ В

\section{САНКТ-ПЕТЕРБУРГЕ - ТЕРРИТОРИЯ СМЫСЛОВ}

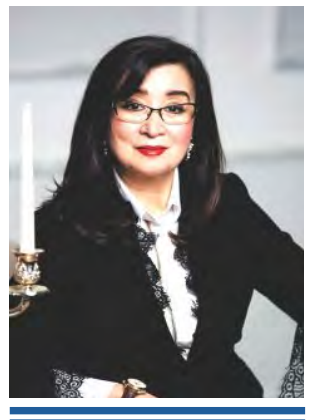

Шахноза Ганиева, известный журналист и искусствовед

Во время пребывания эмира в Санкт-Петербурге он неоднократно на аудиенции

у Российского

Императора

Николая II

поднимал вопрос

о возведении

мусульманского

храма.

C разрешения

Императора,

Бухарский эмир

Сеид Абдул-Ахад

хан выделил

деньги на покупку земельного участка

Unique written and architectural monuments of Islam. They became the unifying factor that connected the East and the West. An example of the deepest ties of Muslims of Russia and Uzbekistan are the historical facts about the construction of the Cathedral Mosque in St. Petersburg more than a century ago.

The northern capital of Russia possesses exclusive collections of written masterpieces created and copied on the territory of Uzbekistan, but by the will of fate ended up on the banks of the Neva.

Katta Langar Quran - the rarest copy of the sacred list of Muslims, dating back to the 8th century. Since the 19th century it has been kept in St. Petersburg.

This article talks about the construction of a mosque in St. Petersburg and the history of the sacred Muslim manuscript.

Key words: Mosque, Muslims, construction, collections, Quran, history, manuscripts.

Санкт-Петербург... город, который называют Северной Пальмирой. Здесь каждый камень дышит историей. Этот уникальный город европейской культуры, хранит в себе и выдающиеся реликты исламского мира. Здесь, на берегах Невы, в Институте восточных рукописей РАН хранятся уникальные письменные памятники ислама. Они свидетельство того, что великие истории не исчезают бесследно. Именно там, в Санкт-Петербурге в Институте восточных рукописей РАН, хранится один из древнейших и уникальнейших списков - Коран из Катта Лангара. Памятник духовной культуры мусульманского мира был переписан в селении Катта Лангар в VIII веке. Расположенное в отрогах Зарафшанского хребта, это селение в средневековье было центром суфийской обители. И абсолютно очевидно, что там были созданы наиболее старинные списки Корана. 81 лист вертикального формата - один из редчайших образцов, всемирно известного Корана Османа. Работая в Институте восточных рукописей РАН над фролиантами и манускриптами, переписанными на территории Узбекистана, меня интересовал вопрос, как этот бесценный список оказался в Санкт-Петербурге.

Катта Лангарский Коран был приобретен российским дипломатом сирийского происхождения Селимом Науфралем в 1872 году в городе Шахрисабзе, и лишь через 64 года, хранившийся в его личной библиотеке бесценный Коран был продан в Фонд Института восточных рукописей его внучкой. «Понятно как у меня вздрогнуло сердце, когда однажды осенью 1936 года в моих руках оказались несколько десятков листов пергамента с типичным старинным кусрическим шрифртом, которая принесла в Институт продавать какаято дама ... » так описано академиком Игнатием Крачковским - одним из первых переводчиков Корана, история приобретения бесценной рукописи. Он написал об этом в ценной для каждого востоковеда, книге «Над арабскими рукописями».

Еще одним реликтовым памятником ислама в Санкт-Петербурге является самая крупная в Европе, соборная мечеть. Во время религиозных праздников и намазов она вмещает в себя более 5000 человек. Ее устремленные в небо, 48 метровые минареты и главный купол - свидетельство глубочайших традиций мусульманской архитектуры. И, пожалуй, главное - мечеть это символ толерантности многонациональной империи.

Впервые вопрос о постройке молитвенного дома в Санкт-Петербурге был поднят еще в 
1798 году, когда свыше 500 военнослужащих мусульман подали прошение. Позднее, в Санкт-Петербурге, были выполнены проекты мечети знаменитыми архитекторами Андреем Воронихиным и Луиджи Руска, но оба проекта остались нереализованными. И уже в 1882 году муфтий мусульман России обратился в Правительство с прошением о строительстве мечети. Но прошло еще 24 года и только 1906 году Министерство внутренних дел разрешило учредить особый комитет по постройке Соборной мечети за счет добровольных пожертвований мусульман Российской Империи. Вновь созданный комитет обратился за содействием к Бухарскому Эмиру Сеид Абдул-Ахад хану, который имел тесные контакты со столичной мусульманской общиной.

Во время пребывания эмира в Санкт-Петербурге он неоднократно на аудиенции у Российского Императора Николая II поднимал вопрос о возведении мусульманского храма. С разрешения Императора, Бухарский эмир Сеид Абдул-Ахад хан выделил деньги на покупку земельного участка. Параллельно Комитет собирал и пожертвования для строительства мечети. И уже в 1907 году в журнале «Зодчий», Императорское общество архитекторов объявило конкурс на проект здания в Санкт-Петербурге Соборной мечети. В состав жюри вошли выдающиеся архитекторы того времени: Леонтий Бенуа и академик Александр фон Гоген. В конкурсе приняли участие 45 проектов. Интересно, что эти проекты были названы именами личностей, которые были знаковыми для истории культуры Востока - «Абдурахман Джами», «Тимур» и конечно же «Самарканд» - город который всегда был цент-ром притяжения в Средней Азии.

Конкурс выиграл проект «Арабески» гражданского инженера и художника-архитектора Николая Васильева. В основе идеи, как внутренней планировки, так и экстерьера здания, были использованы архитектурные стили мечетей Средней Азии эпохи Тимуридов.

Церемонию закладки мечети приурочили к 25-летию вступления Бухарского эмира на престол. Это был 1910 год. По традиции тех лет, специально для закладки, была заказана серебряная табличка с выгравированным текстом. Цитирую дословно: «1910 год фревраля 3 дня, в присутствии генерал-адъютанта шейха Абдул-Ахад хана - эмира Бухарского заложена сия мечеть на земле, подарен-

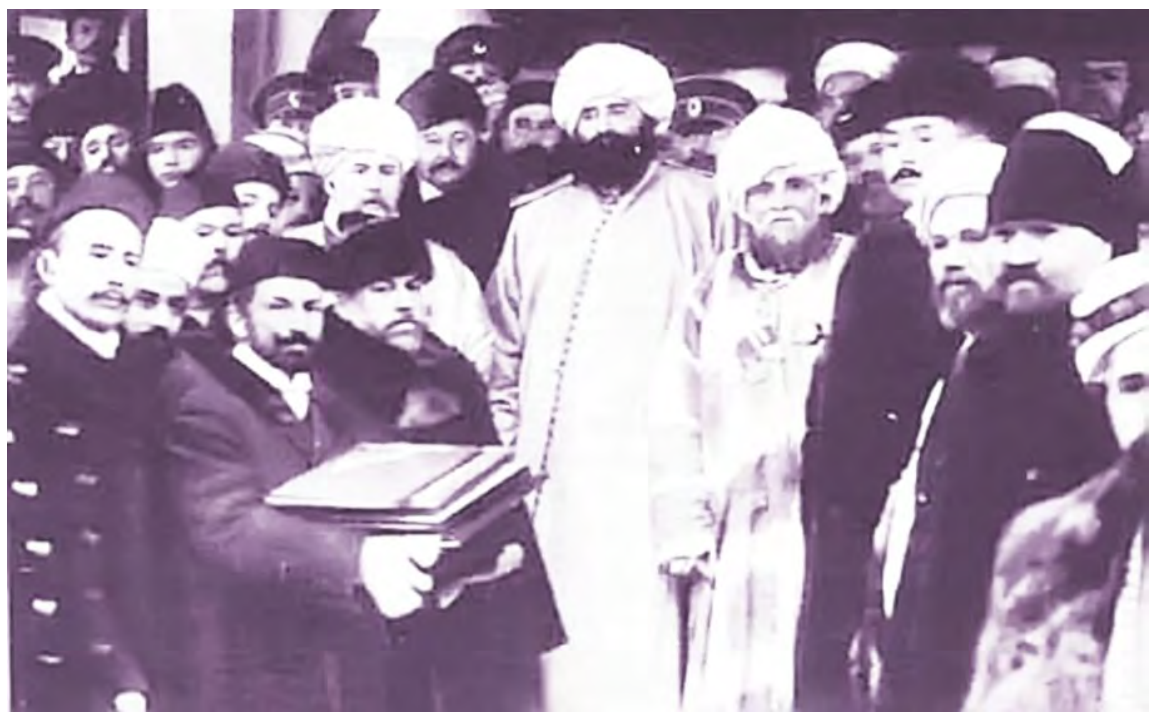

ной Санкт-Петербургским мусульманам Его Высочеством Эмиром». О значение этого события говорит такой фракт, что на закладки мечети присутствовали турецкий посол в России Турхан-паша, персидский посланник Али-Гулихан, Оренбургский Муфтий и представители Духовенства разных конфессий со всей России, а также члены Мусульманской фракции Государственной Думы.

Открытие Мечети было приурочено к 300летию Дома Романовых в 1913 году. Но это было лишь официальное открытие, так как к тому времени, смогли построить только само здание мечети. Отделка интерьеров и внешнего вида, где должны были быть использованы изречения из священного Корана, а также голубая поливная керамика, продолжалась еще несколько лет.

К сожалению, к этому времени Бухарский эмир Сеид Абдул-Ахад хан оплативший стоимость земли под строительство мечети, уже ушел из жизни. Но на открытии мечети присутствовал его сын эмир Сеид-мир Алим хан, который, также как и его отец поддерживал этот проект. На торжества приехал и последний правитель Хивинского ханства Иссрандияр Бахадур хан.

Сегодня Соборная Кафедральная мечеть является действующим мусульманским храмом, а также крупным религиозным и культурным центром. Здесь помнят исторических личностей кто стоял у истоков возведения мечети в северной столице России.

Под грандиозным куполом мечети, знакомясь с уникальным, для северных широт архитектурным памятником, я невольно вспомнила слова великого Джалолиддина Руми: «Человек - это часть мира, но он и основа его».

\section{Церемонию}

закладки мечети

приурочили

к 25-летию

вступления

Бухарского эмира

на престол.

Это был 1910 год.

По традиции тех

лет, специально

для закладки, была

заказана

серебряная

табличка с

выгравированным текстом 


\section{0 ЙИЛЛИК ТАРИХГА ЭГА ПЕРТ ШАХРИ КУТУБХОНАСИ}

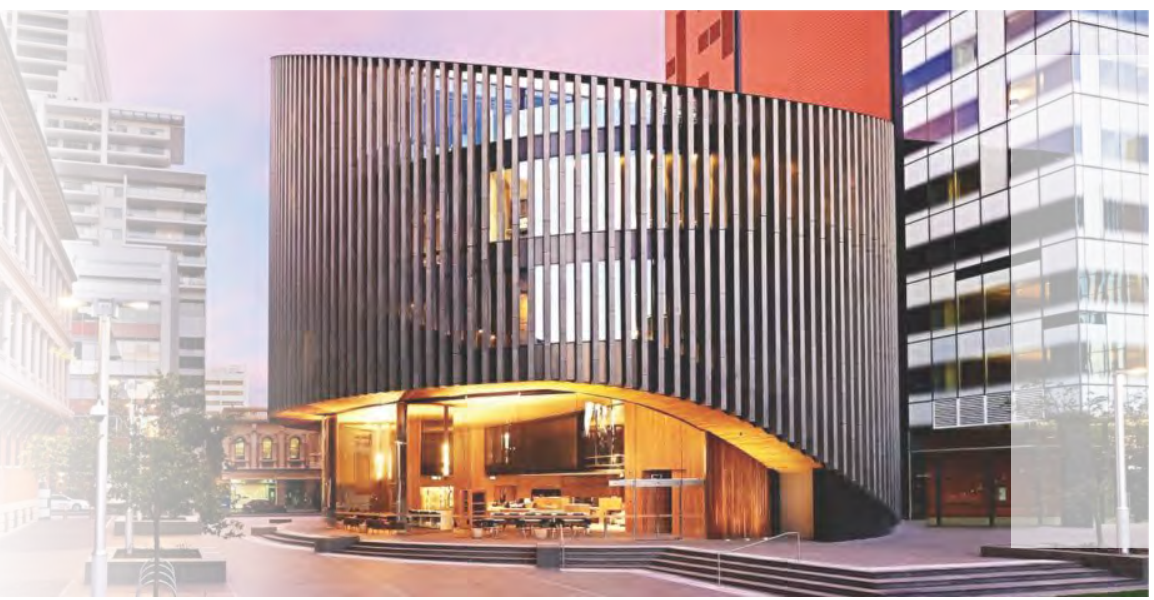

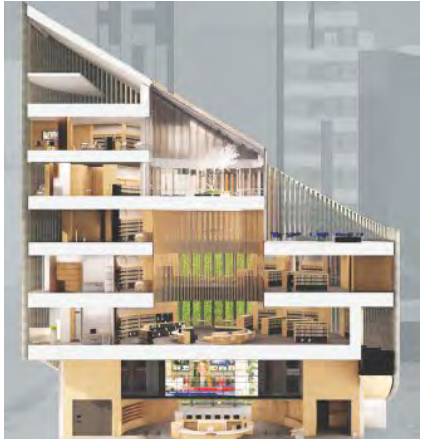

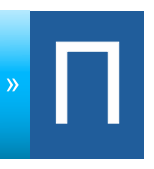
ерт шахри кутубхонаси Перт шахри томонидан тақдим этилган давлат кутубхонаси хизматидир. Кутубхона Хей кўчасида Перт ратушаси билан ёнма-ён жойлашган. У Сен-Жорж хамда Хей, Барак ва Пирс кўчалари ўртасида жойлашган кафедрал собори майдонидаги реконструкциянинг бир қисми хисобланади.

Кутубхонанинг илк фраолияти 1851 йилда ташкил этилган Суон дарёси механика институти биносида бошланган. 1909 йилда институтнинг номи Перт адабиёт институти деб ўзгартирилади, 1957 йилда эса, Перт шахри кутубхонаси деб атала бошланди ва барча нашрларга эга бўлади. Асос солинган даврдан бошлаб 2016 йилда янги бинога кўчиб ўтишигача бўлган давр оралиғида кутубхона шахарнинг бир нечта қисмида жойлашган эди.

Перт шахри кутубхонаси Пертдаги бошқа йирик кутубхонадан - Ғарбий Австралия Давлат кутубхонасидан ажратилди.

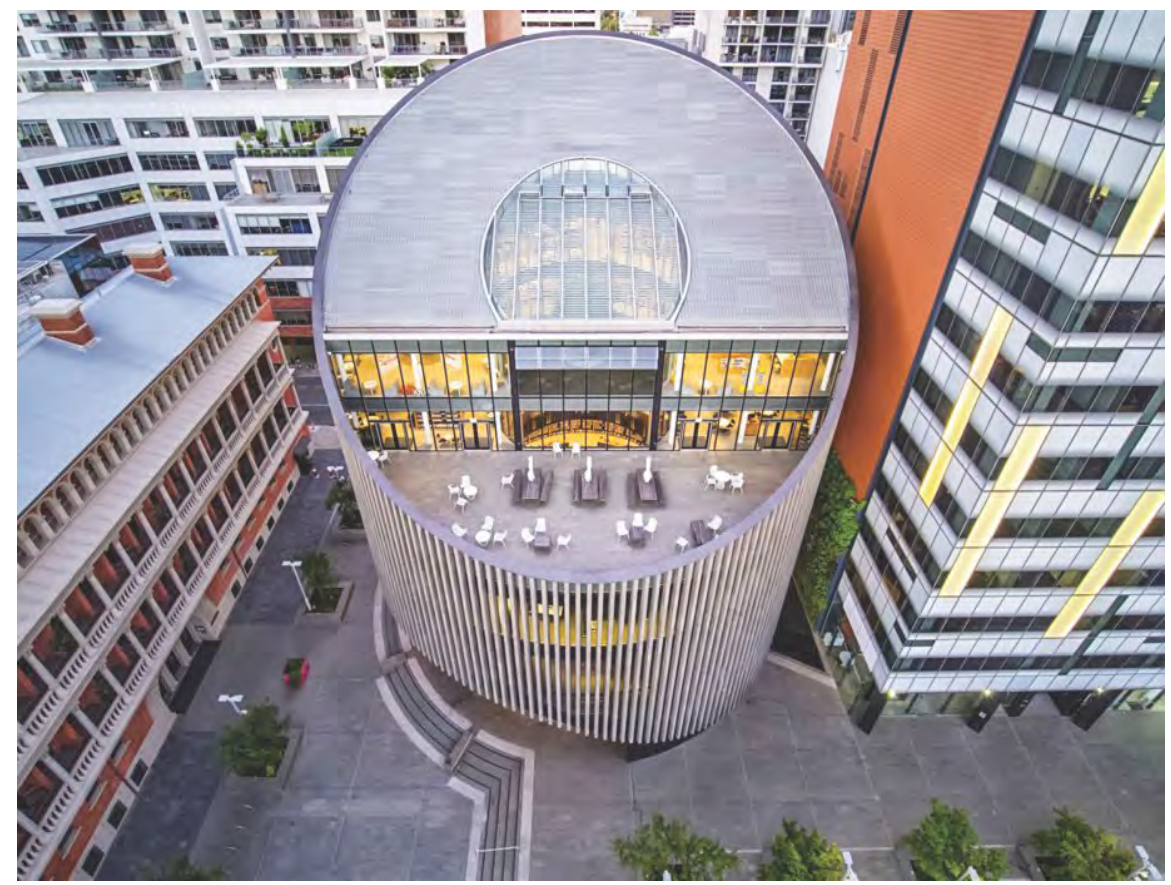

2011 йилда Kerry Hill Architects компанияси янги кутубхонани лойихалаштириш тендерини қўлга киритади. Перт шахри 2013 йилда қурилишни бошлаган Doric Contractors компанияси билан 33 миллион долларлик шартнома имзолади. 170 йиллик тарихга эга янги кутубхона 2016 йил 1 март куни Перт шахрида китобхонларга ўз эшикларини очади.

Перт шахри кутубхонаси - ўтмиш ва келажак кесишган кутубхонадир. У фрасадлари шишакор, устунлари тош билан безалган, айлана шаклдаги етти қаватли бино. Бинонинг ичида 3500 турдаги ўсимлик бор. 13 метрли, Перт шахридаги энг баланд боғ жойлашган. Шифртда Шекспирнинг «Тўфрон» пъесаси сўнгги акти, Ғарбий Австралия наботот ва хайво-

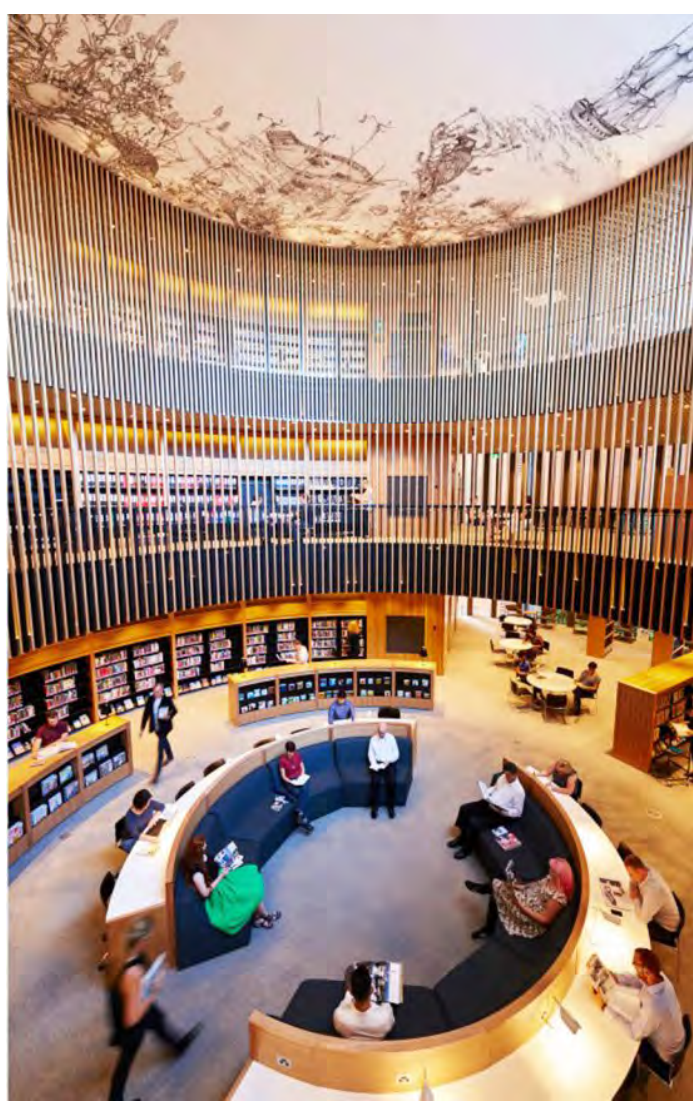


нот олами акс эттирилган рассом Эндрю Николлснинг Delight and Hurt Not (Қойил қол ва ранжима) деб номланган фрескаси тасвирланган.

Кираверишдаги катта очиқ фройеда китобхонлар ёлғиз қолиб мутолаа қилишлари учун сокин бурчаклар мавжуд. Зиналардан кўтарилар экансиз, юқори қаватда жойлашган китоблар ва у ерда китобхонлар учун яратилган қулайликлар билан танишасиз (мажлислар заллари, музокара зали, аудио- ва видеомарказлар, терасса).

Бундан ташқари, бу ерда ота-оналар 1-3 ёшгача бўлган фрарзандларини олиб келишлари мумкин бўлган болалар майдончаси хам мавжуд. Бу очиқ осмон остидаги дарахт атрофрида юмшоқ ўйинчоқлар ва ёстиқлар билан жихозланган, дарё манзарасидан бахра олиш имконини берувчи шинамгина жойдир.

Европача рухда барпо этилган чиройли, янги, замонавий кутубхона фройдаланувчиларнинг манфраатлари ва уларнинг мутолаага бўлган эхтиёжларини қондиришга мўлжалланган. Бу ердан сиз Суон-Ривер дарёсининг оқими остида қоладиган Стрип сохилбуйига очиладиган ажойиб кўринишдан бахраманд бўлишингиз мумкин.

Хозирги, COVID-19 пандемияси даврида кутубхона фройдаланувчилари нафрақат кутубхонага келиб (бир вақтнинг ўзида 300 дан кам фройдаланувчи), балки буюртма орқали уйга етказиб берилган китобларни мутолаа қилиш имкониятига эгадирлар.

Шунингдек, бу ерда Mixed Bag хизмати

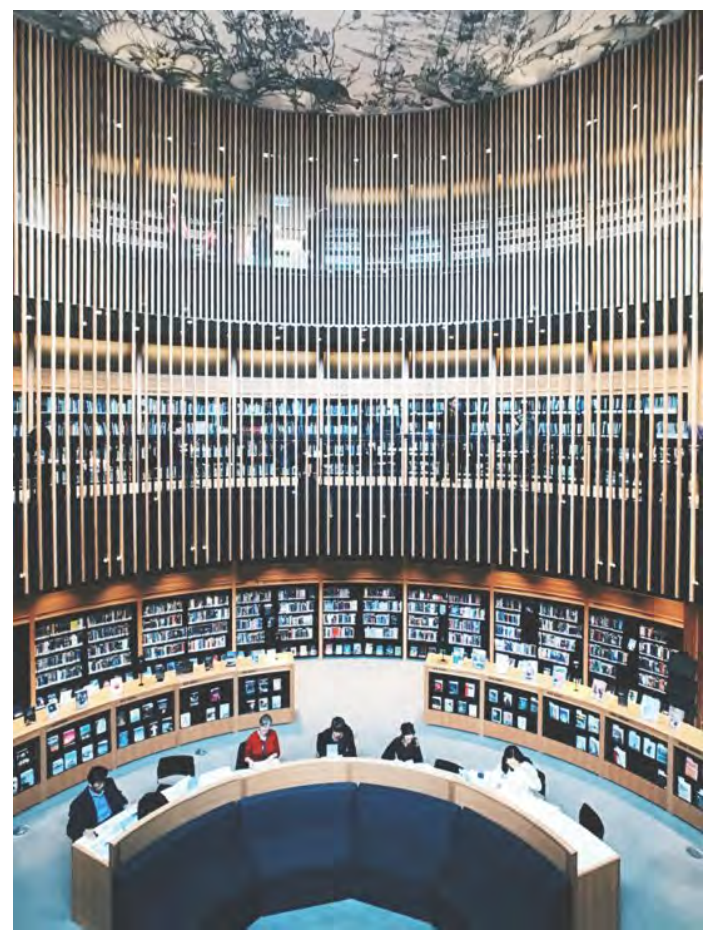

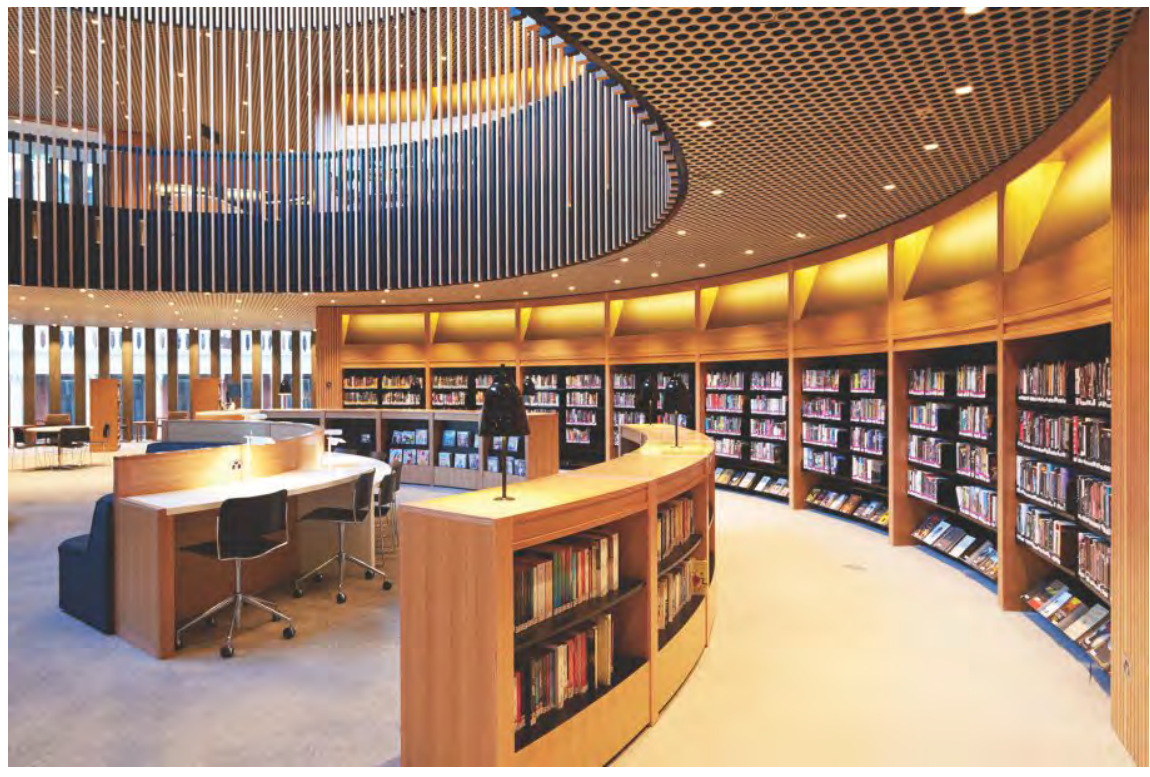

фаолият кўрсатади (Биз танлаймиз, сиз олиб кетасиз).

Фойдаланувчилар учун қулайликлар

Кутубхонага ғарбий Австралияда яшовчи шахслар онлайн аъзо бўлишлари мумкин. Бунинг учун сиз ариза тўлдирасиз, мазкур хужжатни кутубхона электрон манзилига юборасиз, улар кўриб чиқиб ва сизга 24 соат ичида тасдиқлаш хати юборадилар. Тасдиқ хатини олибоқ сиз кутубхона ресурсларидан фойдаланишингиз мумкин. Агар китобни ўзингиз билан олиб кетмоқчи бўлсангиз, биринчи қават кафредрасига мурожаат этишингиз керак, улар манзилингизни текшириб кўриб, сизга китобни расмийлаштириб берадилар.

Агар кутубхонага шахсан келиш ниятингиз бўлса, шахсингизни тасдиқловчи хужжат билан келишингиз кифроя. Кутубхона сизнинг

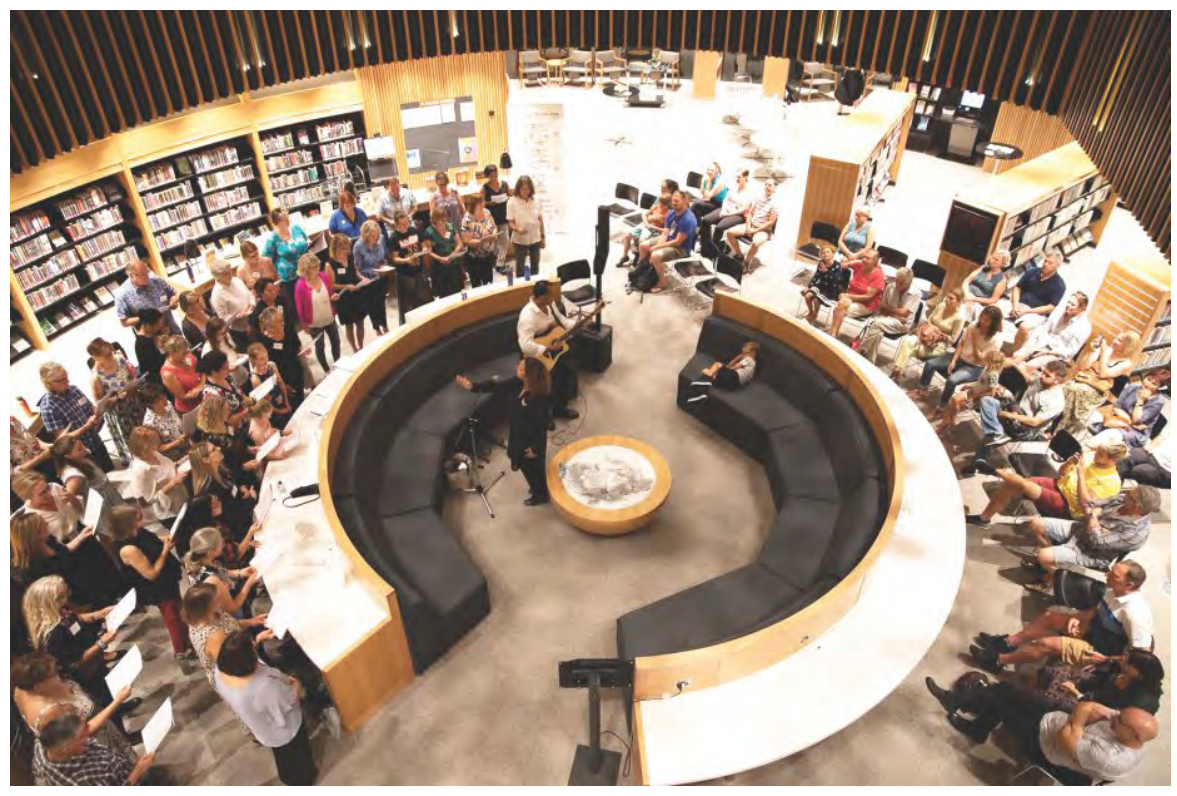


